UNIVERSIDADE DE SÃO PAULO

ESCOLA DE COMUNICAÇÕES E ARTES

SARA MELLO NEIVA

\title{
O Teatro Paulista do Estudante nas origens do nacional popular
}

São Paulo

2016 


\title{
O Teatro Paulista do Estudante nas origens do nacional
}

\author{
popular
}

Dissertação apresentada ao Programa de

Pós-Graduação em Artes Cênicas da Escola de

Comunicações e Artes da Universidade de

São Paulo, para a obtenção do Título de

Mestre em Artes.

Área de Concentração: Teoria e Prática do

Teatro, Linha de Pesquisa: Texto e Cena.

Orientador: Prof. Dr. Sérgio Ricardo de Carvalho Santos.

São Paulo

2016 
Autorizo a reprodução e divulgação total ou parcial deste trabalho, por qualquer meio convencional ou eletrônico, para fins de estudo e pesquisa, desde que citada a fonte.

Catalogação na Publicação Serviço de Biblioteca e Documentação Escola de Comunicações e Artes da Universidade de São Paulo

Dados fornecidos pelo(a) autor(a)

Neiva, Sara Mello

O Teatro Paulista do Estudante nas origens do nacional popular / Sara Mello Neiva. -- São Paulo: S. M. Neiva, 2016 .

$223 \mathrm{p}$.

Dissertação (Mestrado) - Programa de Pós-Graduação em Artes Cênicas - Escola de Comunicações e Artes / Universidade de São Paulo.

Orientador: Sérgio Ricardo de Carvalho Santos

Bibliografia

1. Teatro Paulista do Estudante 2. Ruggero Jacobbi 3. Teatro de Arena 4. Teatro Amador I. Ricardo de Carvalho

Santos, Sérgio II. Título.

CDD 21.ed. - 869.92 
NEIVA, Sara Mello. O Teatro Paulista do Estudante nas origens do nacional popular.

Dissertação apresentada ao Programa de Pós-Graduação em Artes Cênicas da Escola de Comunicações e Artes da Universidade de São Paulo, para a obtenção do Título de Mestre em Artes.

Área de Concentração: Teoria e Prática do Teatro, Linha de Pesquisa: Texto e Cena.

Aprovada em:

Banca Examinadora:

Prof. Dr. Instituição

Julgamento Assinatura

Prof. Dr. Instituição

Julgamento Assinatura

Prof. Dr. Instituição

Julgamento Assinatura 
Para Paulo e Antônio,

com amor 


\section{Agradecimentos}

Agradeço aos meus amigos e familiares queridos, os próximos e os distantes, que de diversos modos me ajudaram a chegar ao fim desse trabalho.

Agradeço aos meus pais e aos meus irmãos pela melhor rede de apoio desse mundo e pelo cuidado com o Antônio, meu filho. Também pelo interesse pela matéria do meu estudo, pela paciência e amor com que sempre cuidaram de mim. Nesta leva, incluo os queridos Júlia Estronioli, Valério e Marcelo. À minha mãe e ao meu pai também agradeço a leitura atenta e generosa, a tradução de um livro inteiro do francês e tanto mais. Ao João e ao Mandú eu agradeço por existirem, por deixarem nossa vida tão mais alegre, por serem meus sobrinhos amados. Agradeço imensamente à Silvia, pelos mesmos motivos, por ter me recebido na família de braços abertos, generosos. Por amar e cuidar com tanto afinco do Antônio. Ao Flávio, ao Felipe e ao Rodrigo, pelo carinho com que me receberam nesta vida. Agradeço aos amigos do Ori Mirim, que todos os dias fazem de lá um lugar vivo, em transformação. Obrigada por nos receberem. Aos meus amigos, parceiros desta vida: Milena, Ana Luiza, Carolina Chmielevski, Marina, Alpha, Tutti, Balza, Renato, Carol Serra Azul, Renan, Paulinha, Gabi, Bruna Lopes, Lua, Liz, Fernanda, Rafaela, Chico, Ju, Virgínio, Vini. À Júlia um agradecimento especial, a "tia monstrinho" do Antônio, pela ajuda inestimável para a pesquisa. Agradeço ao pessoal do LITS, pela relação viva de troca e construção coletivas: à Erika, à Bia, à Mari, ao Paulinho, ao Paulo Fávari (Excelsior), à Patrícia, à Paula Autran (companheira de pesquisa no Rio de Janeiro). Agradeço à Viviane Narvaes, por ter me recebido de maneira tão acolhedora. O mesmo à Sarah Silva Telles, mulher incrível, que 
me acolheu tão bem, na primeira vez que me separava do Antônio, ainda tão pequeno. Ao Armando e Fernando pelo retiro em Gonçalves, pelo passeio gostoso, pelo papo amigo.

Agradeço imensamente à Vera Gertel, por ter me recebido duas vezes, pela história de vida, por ter respondido e-mails e cedido tantos documentos, Foi um grande prazer conhecê-la. Agradeço à Maria Lúcia pela conversa tão emocionante e pela generosidade com que me ofereceu um livro de José Renato Pécora, tão consultado na pesquisa. Agradeço ao Flávio Migliaccio pela excelente conversa e pelo passeio na Urca. Agradeço ao Milton Gonçalves, à Beatriz Segall, à Aracy Amaral, à Tiche Vianna, à Regina Helena de Paiva. Todas essas pessoas, que assumem papéis tão importantes nas páginas desse estudo, me receberam com muita simplicidade, afetuosidade e disposição para o diálogo. Agradeço à Vanya Sant ${ }^{\prime}$ Anna que colaborou muito e gentilmente para a realização dessa pesquisa, fornecendo diversos documentos e críticas de jornais sobre o TPE. Agradeço à Alessandra Vannucci, pela entrevista esclarecedora, pelo material inédito que me forneceu, por sempre ter sido tão solícita em responder minhas dúvidas e confusões acerca de Ruggero Jacobbi.

Agradeço à CAPES pela bolsa que permitiu o desenvolvimento deste trabalho. Agradeço às funcionárias e funcionários do CEDOC-FUNARTE (Centro de Documentação em Arte da Fundação Nacional de Artes) no Rio de Janeiro pela ajuda na consulta aos arquivos. Agradeço à Mariana, funcionária do Arquivo Miroel Silveira, na ECA. Agradeço à bibliotecária Cida da Biblioteca Raul Cortez, da Escola de teatro Célia Helena. Agradeço aos funcionários da biblioteca da ECA, pela disposição com que sempre me ajudaram.

Agradeço à professora Maria Silvia Betti e ao professor Marcelo Siqueira Ridenti pelo privilégio de tê-los participando da banca de qualificação deste trabalho e 
pelos apontamentos determinantes para a continuidade da pesquisa.

Em especial, agradeço ao Professor Sérgio de Carvalho pela orientação do meu trabalho. Devo a ele a escolha desse objeto de estudo tão apaixonante. Agradeço pela confiança e pelo constante diálogo, entre práticas e teorias, nesses anos passados. Agradeço a leitura minuciosa e os apontamentos críticos e precisos. Muito obrigada, professor.

Agradeço ao Antônio, meu filho, pelos melhores momentos da vida.

Por fim, agradeço ao Paulo, companheiro de todas as batalhas, de todas as horas. Não tenho maneiras de agradecer o empenho com que me ajudou a chegar ao fim, até o último minuto do meu lado. Sua leitura atenta e crítica, em cada uma das etapas desse difícil trajeto, impulsionou minha caminhada. Agradeço ao Paulo pelo amor e por seguir ao meu lado. 


\section{Resumo}

Com o trabalho investiga-se o Teatro Paulista do Estudante (TPE), fundado por Gianfrancesco Guarnieri, Oduvaldo Vianna Filho e Vera Gertel - dentre outros, desde sua criação em 1955 até sua fusão com o Teatro de Arena em 1956. Identifica-se ali o início de um projeto nacional popular que influiria decisivamente em todo teatro político posterior, como a fase engajada do Arena e o Centro Popular de Cultura (CPC), até 1964. A pesquisa buscou constituir e analisar as produções artísticas e teóricas do Teatro Paulista do Estudante, bem como os impasses decorrentes de sua prática. Observou-se o TPE à luz, principalmente, das influências do encenador italiano Ruggero Jacobbi; de uma tradição de grupos amadores de intenções populares na década de 1950; e do engajamento ligado ao Partido Comunista Brasileiro (PCB). 


\begin{abstract}
This study aims to investigate the Teatro Paulista do Estudante (TPE), founded by Gianfrancesco Guarnieri, Oduvaldo Vianna Filho and Vera Gertel - among others, since its creation in 1955 until its merger with the Teatro de Arena in 1956. It is identified there the beginning of a national popular project that would influence decisively in all subsequent political theater, like the political engaged phase of the Teatro de Arena and the Centro Popular de Cultura (CPC), until 1964. This research seeks to establish and analyze the artistic and theoretical productions of Teatro Paulista do Estudante and the impasses resulting from their practice. TPE was observed through the influence of the italian director Ruggero Jacobbi; the tradition of amateur groups of popular intentions in the 1950s; and the political engagement from the Brazilian Communist Party (PCB).
\end{abstract}


PARTE I - RUGGERO JACOBBI E O DEBATE SOBRE O TEATRO MODERNO



Capítulo 1 - O teatro amador e os sentidos diversos da modernização ..................................... 14

Capítulo 2 - Movimentos do projeto "nacional popular” na visão de Ruggero Jacobbi......... 41

PARTE II - MODERNIZAÇÃO, ENGAJAMENTO E IMPASSES NA TRAJETÓRIA DO



Capítulo 3 - O imaginário comunista na criação do Teatro Paulista do Estudante................... 84

Capítulo 4 - A Rua da Igreja: estreia e impasse................................................................. 113

Capitulo 5 - Esboço de um programa nacional popular para o teatro amador....................... 140

Capítulo 6 - A fusão com o Teatro de Arena ..................................................................... 167








\section{NOTA INTRODUTÓRIA}

O trabalho apresenta uma reflexão sobre a breve e contundente história do Teatro Paulista do Estudante (TPE), desde sua fundação até a fusão com o Teatro de Arena. Defende-se a ideia de aquele pequeno grupo de jovens tenha gestado ali a possibilidade de outro caminho de modernização para o teatro brasileiro, pautado agora por uma ideia própria de nacional popular.

O estudo procurou situar o Teatro Paulista do Estudante como uma espécie de síntese (provisória) de várias forças e, portanto, um ponto chave de inflexão na história recente do teatro brasileiro. Convergiram no TPE: a) uma tradição de teatro amador e popular que buscava efetivar um teatro moderno diverso do modelo esteticista do TBC; b) a influência decisiva do encenador italiano Ruggero Jacobbi com sua elaboração própria do conceito de nacional popular e sua incansável busca por formulações antiburguesas no teatro; c) e, por fim, a forte influência do Partido Comunista Brasileiro (PCB) e de uma nova linha cultural que defendia a possibilidade de engajamento por meio da arte.

O TPE é criado em 1955 por jovens ligados à Juventude Comunista do PCB, como Gianfrancesco Guarnieri, Oduvaldo Vianna Filho e Vera Gertel e já em 1956 funde-se ao Teatro de Arena transformando os rumos do grupo inaugurado por José Renato alguns anos antes. Neste curto espaço de tempo, os jovens montaram ao todo cinco espetáculos. A peça de estreia, A Rua da Igreja, do irlandês Lennox Robinson sugerida e orientada por Ruggero Jacobbi, foi cancelada por vontade de parte dos integrantes logo após a primeira apresentação, marcando um racha político no grupo. Em seguida reuniram-se em nova formação e levaram para o II Festival de Teatro 
Amador a peça Está lá fora um inspetor de J. B. Priestley. Naquele Festival apresentaram ainda uma tese que expunha um avançado programa do grupo em direção a um projeto de teatro popular. Logo em seguida montaram ainda duas peças curtas de Artur Azevedo e, por fim, a comédia O impetuoso capitão Tic escrita em 1861 por Eugene Labiche, estreou no Teatro de Arena e permaneceu algumas semanas em cartaz. São experiências que resultaram num constante impasse, mas que abriram os caminhos para ao menos dois momentos decisivos no teatro brasileiro: a fase engajada do Teatro de Arena e as experiências de democratização da arte na década de 1960, como os Centros Populares de Cultura em todo o Brasil.

Os impasses gerados pelas apresentações aliados às dificuldades de manter um grupo de teatro amador de notável autonomia e atuação política levaram-nos a fundir-se ao Teatro de Arena. Nesse sentido, o TPE figura como um projeto que não chega a se realizar propriamente, mas que demarca posições centrais para o debate sobre teatro e sociedade no Brasil e, com isso, abre as trilhas para as experiências mais avançadas de teatro engajado socialmente que virão a seguir. 
PARTE I

RUGGERO JACOBBI E O DEBATE SOBRE O

TEATRO MODERNO BRASILEIRO 


\section{Capítulo 1}

\section{O TEATRO AMADOR E OS SENTIDOS DIVERSOS DA MODERNIZAÇÃO}

Ruggero Jacobbi aportou no Rio de Janeiro em 1946, num momento em que se intensificavam os debates sobre o sentido da modernização da prática teatral no Brasil. Esse processo decorria de um ciclo de expansão do teatro amador ocorrido na década anterior, que mobilizou ideias diversas sobre projetos diversos para um teatro brasileiro atualizado em relação aos novos padrões europeus.

Aquele que é considerado o marco "oficial” da encenação e modernização teatral no Brasil, a encenação de Ziembinski em 1943 para Vestido de noiva, de Nelson Rodrigues, apresenta apenas um ângulo desse processo. De fato o espetáculo trazia um trabalho de direção autoral com base num texto nacional de forma mais livre do que a do teatro dramático convencional. Entretanto, Vestido de Noiva marcaria, segundo Fernando Peixoto, para além de sua forma, o momento em que a burguesia passou a se interessar pelo teatro com base na percepção de que já era possível de fato superar a condição do atraso, já era possível conquistar o "padrão internacional” de peças bem feitas, "sufocando os caminhos mais espontâneos e autênticos do teatro nacional, e inaugurando um tipo de postura ideológica, esteticista e burguesa"1. Afinal, até aquele momento, a alta elite carioca ia ao teatro somente para assistir às turnês europeias ${ }^{2}$, o que de qualquer modo se inviabilizou com a Segunda Guerra. Mas, para Fernando Peixoto, o processo de modernização não deveria ser visto apenas por este ângulo. Surgia a questão, também, de uma nova relação funcional do teatro:

\footnotetext{
${ }^{1}$ PEIXOTO, F. Teatro em Movimento. São Paulo: Hucitec, 1989, p. 44.

2 Cf. Depoimento de Luiza Barreto Leite In: MIRANDA, O. (Org.). Coleção Depoimentos II Personalidades Teatrais. Rio de janeiro: Serviço Nacional de Teatro, 1977, p. 92.
} 
Está aberto o caminho para uma geração assumir o teatro como realização mais aprofundada e objetiva com a realidade, deixando de lado certa ingenuidade em nome de um período de forte mas fecunda influência do teatro europeu ${ }^{3}$.

Antonio Candido, no texto Os feitos da burguesia ${ }^{4}$, apresenta a ideia de que "feitos" como as obras de arte produzidas pelo Teatro Brasileiro de Comédia e a empresa cinematográfica Vera Cruz, por exemplo, por estarem ligados à classe que os criou, representam, em algum nível, as ideologias e interesses dessa classe. Por outro lado, tais empreitadas conservam, ao mesmo tempo, certa autonomia, que faz com que tenham personalidade própria e possam, até certo ponto, escapar da função de classe que lhes deu origem.

Nesse sentido o processo de modernização brasileiro, apesar de geralmente ligado à burguesia, a ricos industriais amantes da arte, teve um sentido contraditório, ultrapassando em vários momentos os interesses burgueses. Isso explicaria, para o autor, como alguns acontecimentos notadamente de esquerda, antiburgueses, puderam acontecer dentro do TBC e da empresa cinematográfica Vera Cruz. Os grandes exemplos, não por acaso teatrais, seriam a encenação de Ralé de Gorki, dirigida por Flaminio Bollini, $O$ mentiroso, peça de Goldoni montada por Ruggero Jacobbi e $A$ ronda dos malandros, adaptação de Jacobbi feita a partir da Ópera de três vinténs de Brecht e da Ópera do mendigo, libreto setecentista de John Gay.

Para Antonio Candido, foi esse tipo de atuação, na contracorrente da maré burguesa, que permitiu criar as bases para que, na década seguinte, movimentos

\footnotetext{
${ }^{3}$ PEIXOTO, F. Teatro em questão. São Paulo: Hucitec, 1989, p. 66. O grifo é nosso.

${ }^{4}$ CANDIDO, A. Os feitos da burguesia. Revista Discurso. São Paulo, no 11, pp. 125-130, 1979.
} 
politizados e ligados a "setores mais vastos da sociedade" tornassem possíveis um caminho de modernização de sentido democrático e popular ${ }^{5}$.

Antonio Candido, bastante atento às contradições do movimento em São Paulo não comenta a experiência de modernização que se iniciou antes no Rio de Janeiro com os grupos de extração amadora como Os Comediantes e o Teatro do Estudante criado por Paschoal Carlos Magno. Não obstante, são experiências que poderiam ser enquadradas neste mesmo padrão: foram fomentadas dentro de aparelhos burgueses e financiadas pela alta sociedade do Rio que se interessava pelo desenvolvimento das artes, porém a prática não se restringia ao campo ideológico burguês. Em muitos casos foram grupos que tiveram atuação contraditória ou ferrenha disputa interna sobre os caminhos que a modernização do teatro deveria percorrer.

\section{Projetos em disputa}

A companhia Os Comediantes, por exemplo, sempre lembrada pela encenação de Vestido de noiva, nasceu marcada por grandes tensões internas. Luiza Barreto Leite, uma das fundadoras junto com Brutus Pedreira e Tomás Santa Rosa, é um exemplo de uma figura cujas posições destoavam do campo social que possibilitou a existência do grupo. Filha de intelectuais do Rio Grande do Sul, ela mudou-se para o Rio de Janeiro e logo fez amizade com os modernistas Raul Bopp e Oswald de Andrade. Ainda em 1935, juntos pensaram em montar $O$ homem e o cavalo, de Oswald, que chegou ainda a escrever A Morta para estrear nesse grupo de teatro que acabou se dispersando.

\footnotetext{
5 "A respeito disto, poderíamos realmente falar de um tipo de cultura que, embora influenciada por pessoas que na sua maioria eram individualmente da burguesia pela origem, estavam desprendendo-se dos valores burgueses. Refiro-me a coisas como as tentativas de teatro popular, as caravanas para o Nordeste que viu surgir a obra de Paulo Freire, o cinema novo etc.” (Id. Ibid., p. 128).
} 
De todo modo, antes de fundar Os Comediantes, a atriz tentou colocar em prática parte daqueles "sonhos modernistas politizados" da década de 1930 que, segundo Sérgio de Carvalho, chegaram a ser muito mais avançados "do que foram capazes aqueles que efetivamente modernizaram a cena brasileira na década de 1940 "6.

As posições de Luiza Barreto Leite contribuem para vislumbrar mais nuances e contradições do período. De seu ponto de vista, a disputa não se dava simplesmente entre o ímpeto modernizador de atualização elitista e um teatro comercial considerado rebaixado, "popularesco", baseado no modelo profissional das companhias itinerantes vigente desde o início do século. Sem interesse numa polarização simples, o nascimento de sua companhia fundou-se numa disputa formal, temática e produtiva e acabou, na prática, se tornando um dos responsáveis pela realização de certo teatro moderno nas artes cênicas brasileiras.

Segundo a atriz, já em 1942, quando Ziembinski se aproximou do grupo, eles estariam divididos em duas vertentes: "a parte das estrelas, interessada em maravilhosos espetáculos, e a nossa parte, interessada num teatro mais simples"7. Ela diz ainda que havia em Os Comediantes uma parte preocupada em atrelar o teatro às circunstâncias históricas pelas quais passava o Brasil, como a guerra, por exemplo ${ }^{8}$. Ou seja, havia a luta por se fazer um teatro diferente daquele que existia, luta esta que não se resumia a uma simples equação entre teatro de arte contra um teatro comercial.

Depois da experiência com o Vestido de Noiva, descontente com o rumo do grupo, cuja temporada no Teatro Municipal fora "milionária", financiada pelo

\footnotetext{
${ }^{6}$ CARVALHO, S. Atitude modernista no teatro brasileiro. In: ARAÚJO, A.; AZEVEDO, J. F.; TENDLAU, M. (Org.) Próximo ato: Teatro de grupo. São Paulo: Itaú Cultural, 2011, p. 101.

${ }^{7}$ Depoimento de Luiza Barreto Leite In: MIRANDA, O. (Org.). Op. Cit., 1977, p.86.

${ }^{8}$ Luiza Barreto Leite Considerava mais importante que o Vestido de Noiva as montagens, também dirigidas por Ziembinski, de Orfeu de Jean Cocteau, em 1942, feito em benefício da Cruz Vermelha Brasileira, quando o Brasil entrou na guerra, e de Pelleas e Melisanda, de Maurice Maeterlinck, de 1944. (Depoimento de Luiza Barreto Leite In: MIRANDA, O. (Org.). Op. Cit., 1977, P. 87).
} 
Ministério da Educação, Luiza Barreto Leite resolveu sair da companhia ${ }^{9}$. Segundo ela: “o Ziembinski trouxe para o Municipal os banqueiros, empresários, industriais, que só viam teatro europeu" $"$. Por outro lado: "Nós queríamos fazer, posso garantir mais por mim e pelo Santa Rosa, aquilo que o Arena fez 20 ou 30 anos depois. Era esse teatro que queríamos". ${ }^{11}$ Mesmo sendo algo dito muitos anos depois pela atriz, não deixa de ser uma declaração surpreendente.

Além disso, segundo a Luiza Barreto, mesmo o campo social que constituía propriamente o grupo não era hegemônico, havia relativa mistura de classes. De fato, faziam parte dele representantes da alta sociedade, como Evangelina da Rocha Miranda, Edgar da Rocha Miranda, mesmo Gustavo Dória e Brutus Pedreira (a própria Associação dos Artistas Brasileiros, do qual tomaram parte no período amador seria "o núcleo da alta burguesia intelectual"12, de acordo com Luiza). No entanto, Os Comediantes não se resumiam a essa cúpula, participavam estudantes pobres do colégio Pedro II e mesmo Tomás Santa Rosa, que nas palavras dela, "era um mulato paupérrimo". Também jovens artistas intelectuais progressistas, como era o caso da própria Luiza, que romperam ideologicamente com a própria classe. Tinha "gente de todas as classes"13. De todo modo, o projeto defendido por Luiza e Tomás Santa Rosa foi suplantado pelo caminho de fundamento mais elitista e esteticista.

\footnotetext{
${ }^{9}$ Após a saída, Luiza Barreto Leite vai trabalhar no Teatro Dulcina, com orientação de Maria Jacintha que tinha uma visão muito ampla e humanista de teatro - se interessava por clássicos como Santa Joana de Bernard Shaw e Garcia Lorca, chegaram a fundar uma Associação Garcia Lorca no clube Republicano Espanhol, que depois virou clube Garcia Lorca. Depois disso é convidada por Bibi Ferreira para ingressar em companhia fundada por Miroel Silveira e Carlos Lage, em 1944 para fazer A Moreninha com Maria Della Costa (em sua estreia no teatro) no Teatro Fênix. Em seguida é chamada de volta a trabalhar nos Comediantes, que passaram a se chamar V Comediantes.

${ }^{10}$ Depoimento de Luiza Barreto Leite In: MIRANDA, O. (Org.). Op. Cit., 1977, p. 88.

${ }^{11}$ Id. Ibid., p. 87.

${ }^{12}$ Id. Ibid., p. 90.

${ }^{13}$ Id. Ibid., p. 90.
} 
Boa parte do trabalho de Ruggero Jacobbi no Brasil pode ser visto como a tentativa de se conectar com esse caminho preterido no processo de modernização do teatro.

\section{Defesa do teatro amador}

Ao aportar no Rio de Janeiro em 1946, Ruggero Jacobbi participou de duas experiências teatrais, justamente aquelas que mais tensionaram o sentido de moderno que ia se impondo no processo brasileiro. Foram elas: o Teatro Popular de Arte (TPA), fundado em 1948 e o Teatro do Estudante, onde Jacobbi entrou em 1949.

O Teatro do Estudante surgiu no Rio de Janeiro em 1938, antes de Os Comediantes e dez anos antes do TBC. A grande influência de Paschoal Carlos Magno para sua fundação esteve nos trabalhos de Renato Vianna e na experiência do Teatro de Brinquedo, de Álvaro e Eugênia Moreyra, com quem trabalhou no fim dos anos 1920. Sua estada como vice-cônsul do Brasil em Manchester de 1933, também foi importante para a formação de sua visão teatral. No período em que viveu na Inglaterra reconhece a importância do teatro como fator educativo. E é ali também que, de certa forma, passa a enxergar uma possibilidade de conciliar a ideia do teatro de arte com o teatro de diversão:

[Na Inglaterra] eu aprendi a respeitar muito mais o teatro, o teatro com T maiúsculo. E aprendi também a respeitar o teatro digestivo, porque foi quando vi que teatro é também teatro digestivo, que deve ser bem feito, bem encenado, bem dirigido. Essa bobagem de teatro que faz rir 
não merece consideração é burrice de meia dúzia de galináceos. O importante é se o teatro é bem representado ${ }^{14}$

Paschoal Carlos Magno trabalhou intensamente pelo teatro amador. Defendia nos palcos a prosódia brasileira e levantou a bandeira de um teatro nacional num momento em que outros "renovadores" procuravam repertórios internacionais. Ele estimulou e procurou encenar autores novos, lançou muitos dos mais proeminentes atores, professores e diretores do teatro de seu tempo. O Teatro Experimental do Negro, por exemplo, nasceu a partir de debates acalorados nas conferências do Curso de Férias de Teatro, que Paschoal Carlos Magno promoveu em 1944, no Teatro Fênix ${ }^{15}$.

Em 1948, no mesmo ano de fundação do TBC havia percorrido praticamente o Brasil inteiro divulgando, incentivando e orientando a prática teatral, a necessidade de teatro para os jovens, o incentivo a autores nacionais, a ideia de encenação, etc. ${ }^{16}$ Em pouco tempo, diversos grupos de capital importância começaram a surgir Brasil afora. O Teatro de Estudante de Pernambuco, fundado por Hermilo Borba Filho teve colaboração e influência decisiva de Paschoal. Juntos lançaram ainda a iniciativa de teatro popular

\footnotetext{
${ }^{14}$ Depoimento de Paschoal Carlos Magno In: MIRANDA, O. (Org.). Op. Cit., 1977, p.159.

${ }^{15}$ Id. Ibid., p. 159.

${ }^{16}$ Em 1945 viajou ao Norte e Nordeste do país, onde recebeu homenagem do Teatro dos Amadores de Pernambuco (TAP) e fez ação junto ao governo de Belém para que não cerceassem o trabalho dos grupos amadores e dos jovens. Também ajudou a tornar conhecido o autor Ariano Suassuna em 1948, através da criação de um prêmio em Pernambuco chamado Nicolau Carlos Magno; fundou o seminário de Arte Dramática no Rio de Janeiro; no Maranhão fez palestra no centro Gonçalves Dias sobre "Cultura, Teatro e Povo"; levou a encenação que o TEB fez de Hamlet, de Shakespeare, com direção de Hoffmann Harnisch para São Paulo, com 16 apresentações, causando forte impacto na cena paulista, revelando o talento do jovem Sergio Cardoso. Em 1952 Paschoal Carlos Magno inaugurou em sua própria casa o Teatro Duse, um teatro sem bilheteria. A missão era lançar jovens e desconhecidos autores brasileiros, novos atores, diretores e técnicos de teatro. Nesse mesmo ano viajou novamente por todo Norte e Nordeste do país, por suas capitais, apresentando o repertório do TEB: Sófocles, Eurípedes, Shakespeare, Ibsen, Gil Vicente e Martins Pena. Paschoal realizou ainda festivais amadores por todo o Brasil, sempre tentando subsídios governamentais. Criou em 1957, por exemplo, os Festivais Nacionais do Teatro de Estudante, lançando textos como Morte e vida severina, de João Cabral de Melo Neto (REVISTA DIONYSOS. Rio de Janeiro: MEC-SNT, nº 23, set. 1978, p. 19).
} 
ao ar livre, o Teatro da Barraca ${ }^{17}$. Em São Paulo foi responsável pela aula inaugural da EAD, de Alfredo Mesquita ${ }^{18}$.

Em 1949, Ruggero Jacobbi foi convidado a dirigir uma peça para o Festival Shakespeare organizado pelo Teatro do Estudante de Paschoal Carlos Magno. Foi assim, pouco depois de sua chegada ao Brasil, que Jacobbi entrou em contato com esse movimento que de certo modo visava a um desenvolvimento menos elitista da modernização. Foi a partir de sua experiência junto ao TEB, e pelo incentivo do amigo Paschoal Carlos Magno, que Jacobbi começa sua batalha em defesa do teatro amador empenhando-se, nos anos seguintes, em criar uma vertente paulista das possibilidades abertas no Rio de Janeiro e em Pernambuco.

Assim, a ideia de criar um Teatro Paulista do Estudante veio de Paschoal Carlos Magno, que sugeriu isso a Ruggero Jacobbi em $1952^{19}$. Em todo esse processo, é difícil dizer o quanto o grande movimento de teatro amador iniciado na década de 1930 tinha consciência de seu alcance social. É evidente, porém, que sua ação se deu num campo muito maior do que o da renovação estética, tendo implicações críticas e políticas ligadas à própria prática produtiva ${ }^{20}$.

\footnotetext{
${ }^{17}$ Influenciados, por sua vez, pelo famoso teatro de Federico Garcia Lorca, criado em 1931, com subvenção estatal e finalidade popular. A intenção era levar teatro clássico a zonas periféricas.

${ }^{18}$ BRANDÃO, Tania. As companhias teatrais modernas. In: FARIA, J. R. (Org.). História do teatro brasileiro 2 - do modernismo às tendências contemporâneas. São Paulo: Editora Perspectiva e SESC/SP, 2013, p. 83.

19 RAULINO, B. Ruggero Jacobbi - presença italiana no teatro brasileiro. São Paulo: Editora Perspectiva, 2002, p. 158; JACOBBI, R. Autores Nacionais. Folha da Noite, São Paulo, 6.01.1953. In: Crítica da razão teatral. (Organização de Alessandra Vannucci). São Paulo: Editora Perspectiva, 2005, p.12. Nessa crítica de 1953 Ruggero Jacobbi comenta da necessidade de se criar em São Paulo um grupo de Teatro de Estudante aos moldes do que Paschoal Carlos Magno fez no Rio de Janeiro.

${ }^{20}$ Luiza Barreto Leite, em depoimento para a SNT em 1975, concorda que o interesse e o início de um trabalho que levasse em conta a realidade brasileira, que buscasse o autor nacional, nasceu da experiência de Paschoal Carlos Magno, cuja amplitude da ação é imensa. Ela também diz que Paschoal Carlos Magno, a quem esteve muito próxima e com quem trabalhou, não tinha consciência social de sua ação. Ele agiria por instinto: "Quando ele fez o Teatro Duse era pra incentivar os jovens a serem atores, autores e tudo o mais. Pro Paschoal tanto faz que o sujeito seja o que for, contanto que ele seja bom. Também não faz muita questão que seja bom. Ele faz questão é que faça as coisas, que se movimente. Ele realmente é um incentivador imenso do teatro". (Depoimento de Luiza Barreto Leite In: MIRANDA, O. (Org.). Op. Cit., 1977, p. 103)
} 
Será essa conexão entre os campos - que problematiza a própria função do teatro - que se tornará o elemento decisivo para Ruggero Jacobbi. Através da influência da experiência no TEB, ele descobre a força que o teatro amador poderia ter como impulso para outro sentido de modernização de caráter mais democrático, nacional e popular. Esse caminho torna-se uma bandeira de luta estético-política para o italiano nos anos em que viveu no Brasil.

\section{Modernização popular}

A ideia de uma modernização que aproxime experimentação estética e formas não burguesas ligadas a uma tradição popular brasileira, para além de ter se construído no modernismo literário da década de 1920, encontrou manifestações em escritos de diversos autores, entre eles Antonio de Alcântara Machado ${ }^{21}$. Como prática, decorreu do crescimento do movimento amador nos anos seguintes, um movimento que veio a gerar trabalhos como o Teatro do Estudante de Pernambuco (TEP), fundado em 1946 por Hermilo Borba Filho e centrado no interesse pela aproximação modernista entre formas eruditas da Europa do Renascimento e do Nordeste popular ${ }^{22}$.

Um ano antes da fundação do TEP, em 1945, em ocasião da II Semana de Cultura Nacional, organizada pela Campanha do Ginasiano Pobre, Hermilo Borba Filho fez uma conferência que se tornou programa de fundação do grupo. Chamava-se "Teatro, arte do povo" e ali ele refletia sobre a importância de se fazer teatro a partir de temas nacionais, recuperando a história de personagens como Lampião, Maria Bonita,

\footnotetext{
${ }^{21}$ Cf. CARVALHO, S. O drama impossível: teatro modernista de António de Alcântara Machado, Oswald de Andrade e Mário de Andrade. Tese (doutorado em Literatura Brasileira), Faculdade de Filosofia, Letras e Ciências Humanas, Universidade de São Paulo, São Paulo, 2002.

${ }^{22}$ Vários dramaturgos despontaram nesse período buscando essa aproximação com o povo, como Ariano Suassuna, o próprio Hermilo Borba Filho, Aristóteles Soares, José Carlos Cavalcanti Borges e outros.
} 
Zumbi, Antonio Conselheiro. Este teatro deveria se voltar em todos os níveis para uma relação com o povo:

Que se faça teatro com esse material e a multidão sairá das feiras para as casas de espetáculo e daí partirá a compreensão para as obras de elite. Que se acostume primeiro o povo com os dramas que vivem dentro do seu sangue. [...] o teatro brasileiro tem vivido fechado nas casas de espetáculos, caro, inaccessível ao bolso da maioria. O nosso teatro precisa de umas férias. Precisa tomar ar, respirar a plenos pulmões ${ }^{23}$.

Esse movimento logo ganhou críticos, entre eles Gilberto Freyre ${ }^{24}$, que viam no gesto uma atitude paternalista e elitista, o movimento de converter a arte numa mensagem que seria levada ao povo. Contudo, essas experiências em Pernambuco, que culminariam anos depois no Movimento de Cultura Popular (MCP), foram uma tentativa de se criar uma hegemonia de cultura popular. Seu pressuposto era a confiança, por vezes ingênua, mas sempre algo avançada em relação às tendências dominantes, de que haveria um segundo momento em que o aparelho produtivo estaria nas mãos do próprio povo ${ }^{25}$.

Também no Sudeste um significativo projeto de modernização popular foi experimentado. Depois de uma malfadada tentativa de fusão com Os Comediantes no Rio, Miroel Silveira junto a Maria Della Costa e Sandro Polloni colocaram em atividade

\footnotetext{
${ }^{23}$ BORBA FILHO, Hermilo Apud PONTES, J. O teatro moderno em Pernambuco. São Paulo: Buriti, 1966, p. 103-104.

${ }^{24}$ FERNANDES, Nanci. Amadores Paulistas. In: FARIA, J. R. Op. Cit., 2013, p. 78.

${ }^{25}$ Nanci Fernandes em texto para o livro História do teatro brasileiro comenta que a ideia de um grupo como o Teatro do Estudante de Pernambuco era que numa segunda etapa o povo efetuasse a criação (Id. Ibid., p. 77).
} 
o Teatro Popular de Arte $^{26}$. Nas palavras de Miroel, em depoimento para a coleção

Depoimentos do Serviço Nacional de Teatro no ano de 1975, o que o levou a batizar o

grupo tinha a ver com a ideia de um teatro de "arte para o povo":

Eu achei bom porque com Os Comediantes eu não tinha conseguido

levar adiante um dos meus postulados, que era o de fazer um teatro

popular. Eu tinha feito a revolução na parte artística, mas na parte

popular não tinha conseguido nada. No inicio do Teatro Popular de

Arte, eu pretendia fazer um teatro de arte para o povo, num sentido de

conscientização política também. Tanto que eu tinha feito, naquela

ocasião, uma adaptação do Jubiabá, do Jorge Amado, que foi

preterida pela adaptação do Graça Mello de Terras do sem fim $^{27}$.

\footnotetext{
${ }^{26}$ Miroel já tinha criado no ano de 1945 um grupo chamado Teatro Popular com uma verba que havia arrecadado entre amigos em Santos. Em 1946 foi em viagem ao Rio de Janeiro e encontrou Os Comediantes falidos. O dinheiro havia acabado e não havia mais investimento. De acordo com Miroel Silveira, a alta sociedade - "da qual faziam parte os Guinle, os Rocha Miranda, Barão de Saavedra" - que no tempo de amadores os sustentavam em troca de ingressos para as peças, havia decidido romper o financiamento. Miroel Silveira encontrou Ziembinski trabalhando em Cassinos, tendo de aceitar qualquer trabalho. Propôs então que ele dirigisse o Teatro Popular de Arte. Chegaram a assinar contrato. Iam estrear Desejo de O`Neill, com Olga Navarro e Jardel Filho. Segundo o depoimento de Miroel Silveira, Brutus Pedreira, que na ocasião dirigia a companhia Os Comediantes, sugeriu que unissem os dois grupos e se profissionalizassem. Abafaram por um tempo o nome Teatro Popular de Arte e passaram a se chamar V Comediantes, agora profissionalmente. Estrearam em 1946, no teatro ginástico com a peça Desejo (que era a ideia para o TPA). Na segunda peça já entraram em embate, Ziembinski escolheu um texto que Miroel detestava, A rainha Morta, de Montherlant. Remontaram ainda em são Paulo A rainha morta e Vestido de noiva, com Maria Della Costa e Olga Navarro no elenco. E ainda Era uma vez um preso... de Anouilh. Depois de uma curta temporada em Santos, com Cacilda Becker, Miroel precisou se afastar pois fora diagnosticado com tuberculose, precisando de repouso e tratamento - o que durou três anos. Logo após a temporada em São Paulo - e o afastamento por motivos médicos de Miroel Silveira - ocorreu o rompimento entre o Teatro Popular de Arte e o V Comediantes. Em seguida uma polêmica envolvendo mal entendidos e situações parcamente explicadas: Brutus Pedreira teria comunicado que iriam separar o Teatro Popular de Arte de os V Comediantes e teria espalhado uma história de que Miroel Silveira havia sumido com trezentos mil cruzeiros d'Os Comediantes, da época de amadores. Aparentemente os subvencionadores de Os Comediantes tinham pedido a parte deles de volta e isso teria causado um rombo financeiro no grupo. (Cf. Depoimento de Miroel Silveira In: MIRANDA, Orlando (Org.). Op. Cit., 1977, pp. 125-129).

${ }^{27}$ Depoimento de Miroel Silveira In: MIRANDA, Orlando (Org.). Op. Cit., 1977, p. 130.
} 
Miroel Silveira foi uma figura singular, com posicionamentos radicais e progressistas $^{28}$. Seu livro A outra crítica, publicado em 1976, reúne críticas escritas para jornais entre os anos 1940 e 50. Lá fica explicita sua posição estético-política, para quem a análise do espetáculo não poderia se desvincular de uma análise social. Nutria grande interesse pelo teatro brasileiro de tradição popular, incluindo nessa ideia produções de natureza bem diversas, profissionais e amadoras. No prefácio ao livro, ele explica que sua crítica pode ser lida como uma Outra Crítica em oposição e complemento àquela realizada no mesmo período por Décio de Almeida Prado ${ }^{29}$. Décio escrevia para um dos grandes jornais do país, O Estado de São Paulo, e fazia também uma crítica interessada e programática (a avaliação é dele mesmo ${ }^{30}$ ) no sentido de validar a reforma do teatro na direção daquilo que fazia o TBC. Miroel Silveira, por usa vez, dispunha de acesso a veículos com menor circulação, tecia críticas ao padrão industrial TBC, ao "grã-finismo" na arte, e valorizava iniciativas menos ambiciosas. Seu intuito programático era não desconsiderar a vitalidade do velho teatro brasileiro. Considerava que o TBC produzia uma modernização de tipo industrial, baseada na ideologia da "eterna renovação", sempre feita com autores e atores jovens, liquidando

\footnotetext{
${ }^{28}$ Ele nasceu em Santos em 1914, filho de pais intelectuais, família quatrocentona de Silveiras, Vale do Paraíba. O pai, Valdomiro Silveira, era apontado como criador da literatura regional no Brasil, publicou obras que procuravam trazer o vocabulário dos dialetos usados pelos caipiras paulistas, como seu conto $O$ Riacho, de 1894, editado no volume Os Cablocos, publicado pela Companhia Editora Nacional, em 1920. Sua mãe, também intelectual, dedicava-se ao humor literário, com o pseudônimo de A Baronesa de Itororó. Miroel formou-se em direito pela São Francisco, em 1936, mas logo assumiu a vida de artista intelectual, tradutor de inúmeras peças estrangeiras e escritor ele próprio de literatura. (Cf. SANTOS, J. P. Miroel Silveira - um homem do seu tempo. Dissertação (mestrado em Estética e História da Comunicação), Escola de Comunicação e Artes, Universidade de São Paulo, São Paulo, 2010, p. 37).

${ }^{29}$ SILVEIRA, M. Prefácio. In:___ . A outra Crítica. São Paulo: Ed. Símbolo, 1976, p. 11.

30 "Eu estou convencido de que esta fase, naquele momento, foi necessária porque nós tínhamos um teatro nacional, mas que não era teatro tecnicamente bem feito. Então realmente precisávamos fazer uma renovação e isso só poderia ser feito com um corte mais ou menos drástico em relação ao teatro nacional. Eu senti muito essa tarefa que a minha geração executou e que num certo sentido foi muito dura em relação a certos atores de sucesso. A modificação que introduziu no teatro prejudicou, por exemplo, a carreira do Procópio Ferreira, que naquele momento era um homem de quarenta e poucos anos, bastante jovem, e que perdeu muito público como consequência da renovação introduzida. Como crítico eu me colocava muito nesse problema, sentia um pouquinho de remorsos em relação às gerações mais velhas, mas nunca deixei de criticá-los naquilo que eu achava meu dever". (Depoimento de Décio de Almeida Prado In: MIRANDA, Orlando (Org.). Op. Cit., 1977, p. 46.). Confrontar ainda: PRADO, D. A. Apresentação do teatro brasileiro moderno. São Paulo: Perspectiva, 2001.
} 
os "artesãos" do teatro e os "operários" da cena teatral anterior. Dizia que, diante da precariedade da realidade do teatro brasileiro, "não poderíamos jogar nada fora". Já em 1947, sua crítica para o jornal Folha da Manhã sobre a peça de Edgar da Rocha Miranda, Não Sou Eu, encenada pelos Comediantes no mesmo ano, deixa transparecer seu ideal de busca de um teatro que tratasse da realidade brasileira:

O substrato de Não sou Eu, [...] não tem nada de nosso. A história de sabor pirandelliano nada nos conta de nós mesmos. E nós precisamos de autores brasileiros, de grandes autores brasileiros, brasileiros em tudo e não apenas no idioma. [...] Edgar da Rocha Miranda [...] será preciso apenas que procure viver mais entre nós, integrando-se na realidade brasileira $[\ldots]^{31}$

O seu embate contra um tipo de teatro padrão TBC aparece no artigo Contra o grã-finismo em arte de maneira explícita. Ali ele se coloca contra a dominante via de uma cultura elitista (o grã-finismo) que se impunha no teatro moderno e que, em função disso, exigia um teatro "internacional" bem acabado nos aspectos exteriores mas que, para ele:

leva imediatamente para a fuga dos problemas e às grandes verdades, sempre incômodas. A cena se desvirtua irremediavelmente em refúgio de pirotecnias inofensivas, em deleitosas masturbações para uso de sibaritas. E enquanto isso a verdade do teatro, as suas lutas imensas, a sua busca em direção ao povo, a sua natural função de exprimir-lhe as

\footnotetext{
${ }^{31}$ SILVEIRA, M. Não sou Eu, Folha da Manhã, 15.10.1947. In:___. Op. Cit., 1976, p. 16.
} 
tendências e aspirações, desaparecem, somem abafadas num fru-fru de tafetás e num espoucar de champanha ${ }^{32}$.

De modo contrário, o teatro deveria procurar exprimir os anseios e desejos do povo como um todo, enfrentar os problemas da realidade. Aquilo que Luiza Barreto Leite dizia sobre a necessária busca por um teatro simples tinha propósito semelhante.

Miroel Silveira questionava também, como explica no prefácio de A Outra Crítica, a "valorização de uma estética neorrealista como definitiva". Criticava uma sobrevalorização de um teatro reprodutor do cotidiano familiar, de tendência dramáticorealista. Era essa tendência que atribuía a um encenador como Ziembinski a pecha, em sentido negativo, de "expressionista". Passavam a ser menos valorizadas as formas de renovação mais agudamente críticas em relação ao imaginário dramático, não por acaso formadas em momentos de radicalização antiburguesa, como ocorreu na Alemanha e União Soviética. O raciocínio podia se estendido à forma como eram consideradas as práticas oriundas de uma tradição de um teatro popular formado em períodos burgueses anteriores $^{33}$.

O Teatro Popular de Arte nascia com um projeto particular e universal ao mesmo tempo: pretendia unir a ideia de popular à ideia de arte, conjugar modelos da dramaturgia moderna internacional com a prática local da busca por uma dramaturgia nacional que refletisse particularidades e especificidades, em direção ao povo.

Estrearam em 1946 com Anjo Negro, de Nelson Rodrigues, na linha de criação de Os Comediantes, de acordo com Tânia Brandão ${ }^{34}$. A direção coube a Ziembinski, com Itália Fausta no elenco, o que causou certa sensação pela junção de tendências de

\footnotetext{
${ }^{32}$ SILVEIRA, M. Contra o grã-finismo em arte. In:

${ }^{33}$ SILVEIRA, M. Prefácio. In: Op. Cit., 1976, p. 13

${ }^{34}$ Cf. BRANDÃO, Tania. As companhias teatrais modernas. In: FARIA, J. R. (Org.). História do teatro brasileiro 2. São Paulo: Editora Perspectiva e SESC/SP, 2013, p. 86.
} 
arte aparentemente diversas. Um mês após a estreia de Anjo Negro, no Teatro Fênix (02.04.1948), estreava Tobacco Road (06.05.1933), também no Teatro Fênix, assinalando a primeira direção de Ruggero Jacobbi no Brasil ${ }^{35}$. As duas primeiras peças que Jacobbi dirigiu para o grupo dialogavam com temática naturalista: Tobacco Road, de Jack Kirkland, baseada no romance de Erskine Caldwell; e Teresa Raquin, de Emile Zola, com Itália Fausta no papel principal. Nessa primeira fase, antes da companhia migrar para São Paulo - e por questões comerciais mudar o nome para Teatro Maria Della Costa - o repertório já se diferenciava do comum. Caracteriza-se não só pela temática social, de tendência antiburguesa, mas aproxima-se também de experimentações com dramaturgia de forma mais aberta, a exemplo de Lua de Sangue (Woyzeck) de Georg Büchner, dirigida por Ziembinski, em 1948 no Teatro Fênix.

Para Jacobbi, a presença de Itália Fausta no grupo era profundamente significativa. Ela representava o velho teatro, havia atuado em companhias filodramáticas, no Teatro de Brinquedo e também em companhias profissionais como a de Jaime Costa, e agora integrava e fundava o Teatro Popular de Arte. Representava o elo histórico da tradição popular. Sua presença na companhia, ao lado dos atores jovens, era representativa de um sentido de modernização que Ruggero Jacobbi começava a elaborar, em que o velho teatro não deveria ser apagado por aquele novo na medida em que não poderia suprimir seu sentido histórico. A configuração do grupo representava assim a famosa dialética materialista entre o velho e o novo, sintetizada da seguinte forma por Brecht no poema Procura do velho e do novo: "Como diz o povo: na

\footnotetext{
${ }^{35}$ Há uma controvérsia sobre quem teria efetivamente dirigido o espetáculo, segundo a pesquisa de Tania Brandão. Segundo o depoimento que Sandro Polloni deu a ela, Ruggero Jacobbi teria assinado a direção, mas quem teria dirigido era mesmo Itália Fausta. Mas é difícil saber ao certo a validade da afirmação. A direção de uma forma ou outra ficou atribuída a Jacobbi e tudo indica que o seja. (Cf. BRANDÃO, T. Uma empresa e seus segredos: companhia Maria Della Costa. São Paulo: Perspectiva, 2005, p. 186).
} 
mudança de lua/ A lua nova segura a lua velha/ Uma noite inteira nos braços"36. Ruggero Jacobbi refutava o reincidente "mito do marco zero", pelo qual crítica e artistas acreditam-se sempre à beira da "criação original", a partir de um nada existente do teatro nacional. Era esse raciocínio que, para ele:

[...] ia fazendo do moderno teatro do Brasil uma formação telúrica, um território sem memória. $\mathrm{O}$ teatro tem pai e mãe, nome e sobrenome, data de nascimento e moradia certa. Disso advém sua dignidade, que é uma de povo. O espírito dos velhos e dos novos que andaram "mambembando" por este Brasil, heroicamente ${ }^{37}$.

Esse texto e a insistência para que o novo teatro não simplesmente tentasse tirar de vista a experiência e a prática anteriores do teatro popular-comercial feito no país reúne dois fatores importantes sobre as expectativas de desenvolvimento do teatro nacional. O primeiro é uma desmistificação da ideia de que o teatro considerado popular fosse um sinônimo de um teatro totalmente inserido no mercado. Se é verdade que esses artistas voltavam seu trabalho para a venda que garantia sua sobrevivência, orientando sua atividade totalmente para o mercado de artes, também é verdade que esse mercado era uma construção em ruínas, pois todos andavam precariamente "mambembeando" por aí, ou seja, num desacordo fundamental com um meio burguês não formado. E por estar à margem, por sua condição mambembe, frágil, esse teatro comercial talvez conseguisse, inclusive, manter um contato mais orgânico com amplas plateias, uma relação mais viva com a cena.

\footnotetext{
${ }^{36}$ BRECHT, B. Procura do velho e do novo. In: Bertolt Brecht Poemas 1913-1956 (Seleção e tradução de Paulo César de Souza). São Paulo: Editora 34, 2000, p. 253.

${ }^{37}$ JACOBBI, R. O Milagre da Rua Paim. Folha da Noite, São Paulo, 3.11.1954. In: razão teatral. São Paulo: Perspectiva, 2005, p. 63. Crítica da
} 
O Teatro Popular de Arte entrava na cena teatral incorporando Itália Fausta, que já havia participado como diretora do TEB, em 1938, e que não por acaso mantinha interlocução com o grupo amador de Luiza Barreto Leite. Havia, assim, um campo para quem a modernização em bases elitistas se apresentava como um problema. No Teatro Popular de Arte, Itália Fausta entrou como fundadora e atriz.

Encenaram ainda, após o mencionado Lua de Sangue (Woyzeck), de Büchner, Sonata a Quatro Mãos de Guido Cantini e ainda A Prostituta Respeitosa de Sartre. $O$ Anel Mágico, de Alberto Rebello de Almeida, encerra o ciclo da temporada de 1948 no Teatro Fênix ${ }^{38}$.

Durante a temporada, Jacobbi participou de outro evento de grandes proporções na vida teatral carioca, que ficou conhecido como a "greve do Fênix". Após ameaças de despejo, por não conseguirem pagar o alto valor de aluguel do espaço, ele e o elenco do Teatro Popular de Arte ocuparam o Teatro por dois dias como protesto, chegando a dormir no teatro. Na manhã seguinte ao primeiro dia, jornalistas de diversos jornais estavam lá para fotografa-los, com atenção à celebridade Itália Fausta, dormindo pelos cantos, nas poltronas e sofás. O empresário arrendatário fechou a bilheteria e cortou a luz, mas a notícia espalhada impulsionou um movimento entre os artistas que simpatizaram e se identificaram à causa. O espetáculo foi apresentado sem iluminação, com a casa lotada. Diante disso o juiz cedeu aos artistas do Teatro Popular de Arte a posse do Fênix: "Abriu-se a bilheteria e franqueou-se o teatro ao público"39. Todo o episódio teve forte repercussão na imprensa e nos meios culturais ${ }^{40}$. O caso do Fênix

\footnotetext{
${ }^{38}$ BRANDÃO, Tania. As companhias teatrais modernas. In: FARIA, J. R. (Org). Op. Cit., 2013, p. 86.

${ }^{39}$ Idem. Uma empresa e seus segredos. São Paulo: Perspectiva, 2005. p. 195.

${ }^{40} \mathrm{O}$ prédio histórico onde estava localizado o Fênix, na Rua da Ajuda, havia sido inaugurado como Teatro Eldorado em 1863. Mudou de nome algumas vezes até se chamar Fênix Dramática em 1868. Foi posteriormente demolido para a construção da Avenida Rio Branco. O terreno do teatro havia sido doado à prefeitura, por uma sociedade dramática com a condição de sempre manter em funcionamento um teatro. Mais tarde foi construído o moderno Teatro Fênix. A prefeitura arrendou para o empresário Vital Ramos de Castro até 1945, quando foi desapropriado, reformado e entregue às mãos de Bibi Ferreira. Algum tempo mais tarde Vital Ramos de Castro arrendou novamente o teatro e passou a cobrar das
} 
tornou-se emblema da situação do teatro no Brasil: falta de casa de espetáculos, altos preços cobrados às companhias. Criou-se uma comissão para tentar mapear e propor soluções à questão do teatro nacional, com estudos sobre as subvenções estatais etc., mas sem nenhum resultado imediato significativo.

Depois do episódio, o TPA decidiu sair em excursão pelo país. Ao fim do período vieram a São Paulo, de onde não mais sairiam. Em 1951, inauguraram o Teatro Cultura Artística na capital paulista com o intuito de fazer frente ao modelo $\mathrm{TBC}^{41}$. Em 1954 constroem um teatro próprio em São Paulo, o Teatro Maria Della Costa na rua Paim na Bela Vista. O radicalismo do projeto se mantém, com um programa teatral avançado e progressista. O espetáculo de estreia da nova sede marcou a vinda ao Brasil de Gianni Ratto, que era um importante cenógrafo do Piccolo Teatro di Milano. Ele dirigiu no mesmo ano $O$ canto da cotovia, de Jean Anouilh, considerado pela crítica da época como um dos melhores espetáculos já montados no Brasil. A peça de Anouilh foi assistida por Vianinha e Guarnieri e tornou-se um dos grandes impulsos para que eles se empenhassem na criação do Teatro Paulista do Estudante.

Ruggero Jacobbi em texto para a Folha da Noite, na ocasião da estreia de Canto da Cotovia, faz uma crítica extremamente favorável à peça e ao Teatro Popular de Arte. Para Ruggero, o nome do grupo era o mais "belo e polêmico entre todos os nomes

companhias $35 \%$ da renda e no mínimo 200 mil cruzeiros mensais. Segundo Tânia Brandão, muitas companhias saíram endividadas e prejudicadas de suas temporadas no Fênix, pois não tinham como prever a bilheteria que iriam arrecadar. Foi o caso de Tobacco Road. Eles foram ameaçados de despejo do teatro, por não terem cumprido o acordo de pagamento. Diante disso, os atores decidem ocupar o Fênix: "No sábado, à noite, Itália Fausta, em cena aberta, ao final do segundo ato, ainda maquilada falou ao público presente: 'Os políticos usaram a praça pública, mas os artistas falam do palco. Este é o nosso púlpito'. Em seguida, contou a história dos acontecimentos do Fênix, narrando-os dramaticamente, fazendo a plateia chorar" (BRANDÃO, T. Op. Cit., 2005, p. 195). Tania Brandão ainda comenta que estava o secretário de cultura do governo Dutra naquele dia na plateia, o Sr. Roberto de Aguiar, que prometeu ajudar. No dia seguinte, Itália Fausta fez o mesmo discurso. O resultado foi um enorme envolvimento e adesão dos artistas e companhias, modernos e antigos, como Procópio Ferreira, Henriette Morineau, Sadi Cabral, Ziembinski, Teatro Universitário, Teatro do Estudante e outros.

${ }^{41}$ Tania Brandão aponta inclusive para a possibilidade de Zampari ter se inspirado na ideia de sucesso do TPA no Rio de Janeiro de contratar um jovem diretor italiano. Segundo a autora, foi o exemplo da experiência de profissionalismo e das direções de Ruggero que teriam feito com que Zampari contratasse Adolfo Celi e criasse o elenco profissional do TBC em 1949 (BRANDÃO, T.. As companhias teatrais modernas. In: FARIA, J. R. (Org.). Op. Cit., 2013, p. 89). 
escolhidos pelos nossos conjuntos teatrais", e indicava um caminho que considerava certo e "esplendidamente aberto" 42 . Sandro Polloni e Maria Della Costa, sem perderem o caráter "humanista e proletário", segundo o diretor italiano, saíam com essa montagem, de um ponto de vista técnico, dez pontos na frente da "produção alcançada pelo mecenatismo paulista", isto é, aquela do TBC. E artisticamente estava no mesmo nível. É provável que estivesse destacando a qualidade de um trabalho de cena mais inventivo e livre, avançado em relação ao repertório de bom nível artístico que era semelhante ao do TBC.

O Teatro Popular de Arte já tendo conquistado o público teatral poderia agora alcançar "aquele outro público" que, por falta de recursos, não frequentava as casas de teatro:

Se isso acontecer sentiremos, finalmente, no teatro brasileiro, aquele vento de rua, de praça, de democracia, que se nos afigura o único capaz de vencer certo gosto de mofo, certo sentido de fechado e de incomunicável que, até o momento, nos tem desagradavelmente atingido, mesmo nas melhores realizações. ${ }^{43}$

Em artigo de janeiro de 1955 no jornal Folha da Noite ainda sobre a apresentação do $O$ canto da cotovia, Ruggero afirma:

Um verdadeiro teatro popular serviria para livrar a nossa arte dramática de todos os males que ainda a afligem, ou de todos os

\footnotetext{
42 JACOBBI, R. O Milagre da Rua Paim. Folha da Noite, São Paulo, 3.11.1954. In: Crítica da razão teatral. São Paulo: Perspectiva, 2005, p. 63. Esse texto Jacobbi escreveu em 1954 , na ocasião de inauguração do Teatro Maria Della Costa em São Paulo. Ali ainda eles escolheram manter o nome Teatro Popular de Arte para o elenco, mas logo o nome ficou esquecido.

${ }^{43}$ Id. Ibid., p. 62.
} 
perigos que ainda a ameaçam: formalismo, intelectualismo, esnobismo, provincianismo, burguesismo, grã-finismo, futilidade... Em praça pública não se brinca. Em praça pública o detalhe não tem possibilidade de se fazer passar por fator decisivo, a análise não pode tomar o lugar da síntese, a decoração externa não pode substituir o ritmo e a energia íntima do espetáculo. ${ }^{44}$

Em pouco tempo, as imposições de mercado com suas exigências de culto às estrelas fazem o Teatro Popular de Arte passar a se chamar Companhia Maria Della Costa. Ainda com encenação de Gianni Ratto, em 1955, a companhia contudo segue em seu projeto de excelência técnico-artística ao lançar como autor Jorge Andrade, com a montagem do texto A moratória, considerado por Gilda de Mello e Souza como verdadeiro ato inaugural da dramaturgia moderna brasileira ${ }^{45}$. Em 1955, Ruggero assinou ainda mais uma direção com a companhia, Mirandolina, de Goldoni, texto oriundo da tradição literária clássico-popular italiana. Essa tendência de obras politizadas se amplia em 1958, quando o Teatro Maria Della Costa realiza a primeira encenação profissional de um texto de Brecht no Brasil, A alma boa de Setsuan, com direção de Flaminio Bollini. Sandro Polloni teria encomendado a tradução da peça para Geir Campos ${ }^{46}$. Iná Camargo Costa em $A$ hora do teatro épico no Brasil comenta que

\footnotetext{
${ }^{44}$ JACOBBI, R. Teatro Popular. Folha da Noite, São Paulo, 21.1.1955. In: Op. Cit., 2005, p. 68. ${ }^{45}$ SOUZA, G. M. Teatro ao Sul, 1955. In: Exercícios de Leitura. São Paulo: Editora 34, 2009 As duas peças a que ela atribui o marco do teatro moderno brasileiro são A Moratória, de Jorge Andrade e Santa Marta Fabril S.A., de Abílio Pereira de Almeida, ambas de 1955. A Moratória estreou sob direção de Gianni Ratto pela Companhia Teatro Popular de Arte, no Teatro Maria Della Costa e Santa Marta Fabril S.A., estreou no TBC, dirigida por Adolfo Celi. Ambas as peças tratam do golpe econômico a partir da crise do café e as consequências na vida de uma família proprietária. Mas para a autora, $A$ moratória é a primeira obra-prima do moderno teatro brasileiro: "A moratória nos revela um autor prisioneiro, como as suas personagens, do espaço e do tempo perdido da fazenda. Mas consciente de que este mundo extinto só pode ser refeito pela imaginação, Jorge Andrade lhe dá permanência através da obra de arte" (p. 140).

${ }^{46}$ Em A hora do teatro épico no Brasil Iná Camargo Costa comenta as circunstâncias da tradução e encenação de A alma boa de Setsuan como emblemáticas das relações do teatro brasileiro com o teatro épico de Brecht. Maria Della Costa e Sandro Polloni teriam lido o texto em francês e imediatamente pedido a tradução para Geir Campos, que o fez "a toque de caixa": "Flaminio Bollini já iniciara os
} 
essa encenação do texto de Brecht foi amplamente discutida no Seminário de Dramaturgia promovido pelo Teatro de Arena a partir de 1958, e que Ruggero Jacobbi estaria presente nas intensas discussões do seminário sobre a encenação ${ }^{47}$. Em 1959, um ano após a estreia de Eles não usam black-tie no Teatro de Arena, o Teatro Maria Della Costa foi responsável pela montagem do segundo texto de Gianfrancesco Guarnieri, Gimba, presidente dos valentes, com direção que projetou o jovem Flávio Rangel ${ }^{48}$. Assim como Black-tie, o ambiente de Gimba também era o morro carioca. A encenação foi levada ao Festival do Théâtre des Nations, em Paris, 1960, com excelente recepção. São experiências que mostram a proximidade da companhia com o projeto do Teatro de Arena a partir de 1958. Anos depois, em 1964, Flávio Rangel encenou para a companhia Depois da queda, de Arthur Miller, com cenário assinado por Flávio Império $^{49}$ e em 1968 Fauzi Arap dirigiu Abre a janela e deixa entrar o ar puro e o sol da manhã, de Antônio Bivar (1939). Os últimos espetáculos da companhia foram com direção de Antunes Filho, antigo estagiário do TBC (de Ruggero Jacobbi, inclusive) que, em 1973, encenou Bodas de sangue, de Federico Garcia Lorca e em 1974, Tome conta de Amèlie, de George Feydeau.

ensaios e Sandro ia buscar cada cena para distribuir ao elenco. [...] Uma das marcas dessas condições de trabalho (começando pela tradução do francês) permanece como uma fratura exposta ainda na edição de 1977 da editora Civilização Brasileira, que usamos para os nossos comentários: os quadros, ou cenas, que na edição alemã são simplesmente numerados (num total de 10), na brasileira receberam o dramático nome de atos. Tal 'contribuição' dos tradutores, ao mesmo tempo que revela uma espécie de empenho em 'facilitar a vida' dos leitores, mostra o abismo existente entre o seu repertório dramático e o épico, do dramaturgo.” (COSTA, I. C. A hora do teatro épico no Brasil. São Paulo: Paz e Terra, 1996, p. 52)

${ }^{47}$ Id. Ibid., p. 40.

${ }^{48}$ Gianfrancesco Guarnieri em entrevista para Alessandra Vannucci, em 1997, comenta sobre a escolha do diretor para Gimba, anunciando o que seria já o momento dos brasileiros. Esse comentário de Guarnieri indica uma ideia controversa de que para adotar um ponto de vista nacional popular sobre o Brasil era necessário ser brasileiro: "O Sandro [Polloni] queria dar o Gimba a um diretor italiano. Por confiança. Era minha segunda peça. Eu falei: 'Macché, vamos fazer agora o Gimba, falando desta maneira? Eh no !!' (gesticulando à maneira dos italianos) Eu vinha do black-tie [Eles não usam blacktie], eu estava dono da bola então, eu tinha assistido a um espetaculo do Flávio Rangel que nem tinha estreiado professionalemte. Falei: 'Ou ele ou nada"' (trecho de entrevista inédita de Gianfrancesco Guarnieri a Alessandra Vannucci, São Paulo, 22 de Junho de 1997.)

49 BRANDÃO, Tania. As companhias teatrais modernas. In: FARIA, J. R. (Org.). História do teatro brasileiro 2. São Paulo: Editora Perspectiva e SESC/SP, 2013, p. 91 
Em 1949, após as experiências no Rio de Janeiro com o Teatro Popular de Arte e a direção de Shakespeare no Teatro de Estudantes do Brasil, Ruggero Jacobbi é convidado a mudar para São Paulo e trabalhar no Teatro Brasileiro de Comédia, o TBC, por indicação do cenógrafo Aldo Calvo.

Àquela altura, o TBC já contava com elenco estável profissional formado por quadros oriundos do teatro amador. Também por indicação de Aldo Calvo, o italiano Adolfo Celi já tinha migrado de Buenos Aires a São Paulo para ajudar na organização dos trabalhos da companhia. Foi Celi quem montou o modelo de atividade teatral profissional, em parceria com o próprio dono da empreitada, Franco Zampari. Em síntese, estava em causa a combinação de um repertório atualizado e a procura de excelência técnica em cenografia, figurinos e composição da atuação no que se refere à boa veiculação do texto. Segundo Alessandra Vannucci:

A arte que ele (Celi) dominava como ninguém no TBC funcionaria como paradigma inclusivo, pois seria capaz de oferecer uma antologia ao mesmo tempo abrangente e válida, ou seja, capaz de agradar a qualquer plateia. [...] Podia casar épocas e tradições, acoplar um drama e uma comédia, peças românticas com revolucionárias sem se preocupar com interpretação política e histórica nenhuma. ${ }^{50}$

Jacobbi, como diretor contratado do TBC, realizou quatro espetáculos em menos de dois anos. Em uma de suas últimas entrevista, na década de 1980, para o documentário A Aventura do Teatro Paulista, Jacobbi conta que, ao ser contratado pelo

\footnotetext{
${ }^{50}$ VANNUCCI, A. Missão Italiana. São Paulo: Perspectiva, 2014, p. 112.
} 
TBC, fez uma espécie de acordo em que dirigiria um espetáculo à moda da casa, por dever profissional, e outro da cabeça dele, segundo seu gosto. Os espetáculo feitos com "gosto" foram O Mentiroso, de Goldoni, considerado por muitos o mais belo espetáculo realizado pelo TBC e A ronda dos malandros, tirado de cartaz após a segunda semana e responsável pela saída de Jacobbi da companhia. Só em 1953 ele voltaria para o quadro de diretores com a produção de Treze a Mesa, de Marc-Gilbert Sauvajon e criaria um teatro de vanguarda às segundas feiras, destinado ao experimentalismo, a lançar novos textos, atores e autores.

Sérgio de Carvalho, no posfácio ao livro Teatro no Brasil, de Ruggero Jacobbi, diz que o encenador italiano teria atuado no TBC no sentido de um contraditório desaburguesamento de um repertório que tinha como modelo principal as tendências franco-italianas:

\footnotetext{
Não foi pequeno seu esforço para corrigir os rumos de uma modernização que punha de lado seu passado local e que - ao anular a própria historicidade - assumia um comportamento pouco modernista. Modernização teatral sem atitude modernista, que não sabia extrair seu futuro da "ida ao povo" de que falavam Mário de Andrade e Gramsci $^{51}$
}

Mesmo trabalhando no TBC, os esforços de Jacobbi estavam orientados para o sentido de coletividade do teatro, de lugar de debate e serviço público:

\footnotetext{
${ }^{51}$ CARVALHO, S. Posfácio - Ruggero Jacobbi. In: JACOBBI, R. Teatro no Brasil. São Paulo: Editora Perspectiva, 2012, p. 196
} 
Jacobbi nunca abandonou a ideia de que a arte deve ser feita no meio das pessoas comuns. Nunca deixou de pensar o teatro como o "poema que desce à rua", porque dela provém ${ }^{52}$.

Em síntese, desde que chegou no país em 1946, Jacobbi assumiu um lado numa disputa mais ou menos formulada em torno de rumos da modernização, e sempre trabalhou no sentido de possibilitar sua realização, mesmo em ambientes que supostamente representariam o campo oposto dessa luta, como o TBC, mas que na verdade eram muito mais contraditórios do que parecem à primeira vista.

Essa disputa relativa sobre um projeto moderno, que foi muito além dos centros do Rio de Janeiro e de São Paulo, dialogava com um momento político de redemocratização e com um quadro mundial do pós-guerra, quando o Brasil saía da longa ditadura do Estado Novo e surgiam importantes novas demandas por políticas públicas inclusivas, por reformas da constituição, reformas de leis trabalhistas, nacionalização de indústrias de base etc. ${ }^{53}$ As novas circunstâncias sociais, o crescente posicionamento e protagonismo de parcelas populares foram responsáveis em grande medida por transformações no imaginário e no direcionamento dos intelectuais e artistas em relação ao que, de modo variado, se chamava povo.

Atento a esse processo que repercutia no mundo teatral, trazendo consigo expectativas de transformação socialista, o estrangeiro Ruggero Jacobbi soube, como poucos, perceber as contradições do movimento em curso e, a partir delas, contribuir para a elaboração de uma nova síntese provisória. Articulando sua experiência italiana com práticas ao mesmo tempo progressistas e conservadoras que encontrou no Brasil, Jacobbi viu surgirem as condições para um teatro de natureza antiburguesa no país, um

\footnotetext{
${ }_{53}^{52}$ Id. Ibid., p. 196.

${ }^{53}$ SCHWARCZ, L. M.; STARLING, H. Brasil: uma biografia. São Paulo: Companhia das Letras, 2015, pp. 386-406.
} 
teatro nacional popular - processo nunca realizado porque dependente de um conjunto maior. Nesse caminho, ele teve um papel notável e mesmo determinante ${ }^{54}$. Fernando Peixoto, um entre muitos, o considerava seu mestre. Categórico, afirmou ter sido Ruggero Jacobbi o estrangeiro que mais contribuiu para a formação de base do teatro nacional:

\begin{abstract}
Ruggero, sem nada impor, me abriu os olhos para tudo e me fez compreender o significado do teatro nacional como integrado dialeticamente no processo mais amplo da sociedade brasileira em sua batalha pela emancipação. ${ }^{55}$
\end{abstract}

A atuação de um diretor, crítico e pensador do teatro como Ruggero Jacobbi foi decisiva para fundamentar uma crítica à cultura burguesa operada de dentro e na fronteira do aparelho burguês ${ }^{56}$, gerando em seu "flanco" a própria contestação ${ }^{57}$. Como afirma a pesquisadora Alessandra Vannucci, até a entrada de Jacobbi não havia no TBC,

\footnotetext{
${ }^{54} \mathrm{Na}$ Itália do pós-guerra, Ruggero participou do início da reconstrução democrática em seu país, mas os rastros e destroços da guerra tornavam a tarefa bastante árdua. No Brasil, o movimento era o inverso, havia trabalho e reconhecimento para aqueles talentosos estrangeiros que se dispusessem a enfrentar a vida nos trópicos. Em 1948, Jacobbi foi convidado por Sandro Polloni para dirigir o Teatro Popular de Arte. Em seguida incumbiu-se da difícil tarefa de dirigir Procópio Ferreira, encenando autores inéditos brasileiros como Guilherme Figueiredo. Participou do Festival Shakespeare, realizado pelo Teatro do Estudante do Brasil, de Paschoal Carlos Magno e dirigiu para esse festival, Sonhos de uma noite de verão que estreou no Teatro Fênix, em 1949. Nesse grupo conheceu Sérgio Britto e Sérgio Cardoso, entre outros, com os quais fundou o Teatro dos Doze, sua primeira tentativa de teatro estável no Brasil. Na companhia dirigiu quatro espetáculos, sendo que o de maior destaque foi Arlequim servidor de dois amos, de Goldoni, primeira Commedia dell'arte nos palcos brasileiros. Ruggero passou 14 anos no Brasil passando por Rio de Janeiro, São Paulo e Porto Alegre. Durante o período, trabalhou em diversas frentes da modernização teatral em marcha, foi encenador, crítico e professor e em todos os lugares onde esteve deixou marcas que determinariam novos rumos para o teatro no país. Foi um dos primeiros diretores do Teatro Brasileiro de Comédia (TBC); participou ativamente do debate crítico do momento (escreveu para os jornais: Diário da Noite, no Rio de Janeiro; Folha da Noite, Última Hora, O Estado de São Paulo, em São Paulo; Correio do Povo em Porto Alegre) foi diretor de cinema e sócio da Companhia Cinematográfica Maristela, professor convidado da Escola de Artes Dramáticas (EAD), do CEC (Centro de Estudos Cinematográficos) além de fundar o curso de teatro da Universidade de Porto Alegre.

${ }_{55}^{55}$ PEIXOTO, F. Um teatro fora do eixo. $2^{\mathrm{a}}$ ed. São Paulo: Editora Hucitec, 1997, p 250.

${ }^{56} \mathrm{Cf}$. Depoimento de Antonio Candido colhido para o documentário A Aventura do Teatro Paulista 5 e 6. Série de televisão produzida pela TV Cultura de São Paulo, em 1981. Produção e entrevistas de Júlio Lerner.

${ }^{57}$ CANDIDO, A. Os feitos da burguesia. Revista Discurso. São Paulo, no ${ }^{\circ} 11,1979$.
} 
por exemplo, nenhuma encenação ligada ao teatro popular ou a qualquer teatro de orientação política:

não havia farsas nem comédias ligeiras, vale dizer, chanchadas, vaudevilles ou peças de bulevar, nem títulos representativos das vanguardas e sequer uma tentação de teatro épico - quase que para garantir ao distinto público que jamais seria importunado com um teatro excessivamente intelectual, excessivamente tolo ou excessivamente polêmico. ${ }^{58}$

Em inúmeros dos seus textos de jornais e nos repertórios escolhidos para encenação percebe-se um gesto sempre provocativo, ainda que amigável, em relação às tendências dominantes. O fato é que a visão de Jacobbi sobre a função do teatro e mesmo seu gosto estético não coadunavam com a linha artística do TBC. Evoluíram em desajuste. Ruggero, de algum modo, foi um acidente no percurso, incorporado contraditoriamente ao processo. Ele, por exemplo, dizia abertamente e polemicamente gostar e ver valor artístico naquele teatro "rebaixado", "popularesco" que a nova crítica desprezava. Não se tratava de entender as razões dos autores de teatro comercial, mas de entender as razões do público em gostar de determinado teatro. E a partir dessa inversão da percepção encontrar as qualidades reais daquele teatro diante da vida, que lhe pareciam muitas.

Na coletânea de críticas e reflexões de Ruggero em jornais e revistas no Brasil, organizadas por Alessandra Vannucci, podemos observar a insistência e constância com que ele advogou por um teatro de cunho popular, contra um tipo de realismo burguês pseudo-psicológico e pseudo-intelectual. Essa foi um de seus estandartes em terras

\footnotetext{
${ }^{58}$ VANNUCCI, A. Missão Italiana. São Paulo: Perspectiva, 2014, p. 107.
} 
brasileiras, já antes levantado na Itália do imediato pós-guerra. Ele insistiu em conclamar e atuou junto a muitos grupos nesse sentido, para que o teatro mudasse o sentido conservador e que, apoiado num repertório popular e "verdadeiramente realista", buscasse o contato com o "verdadeiro povo".

Os posicionamentos de Ruggero Jacobbi aos poucos se somavam aos movimentos de trabalhadores que tomavam força no Brasil, que ganhavam grandes dimensões e que aproximou do PCB diversos intelectuais de esquerda. Em outras áreas da cultura, o esforço de muitos intelectuais já estava marcado pela tentativa de aproximação com as massas, de criação de diálogo e cooperação. Os esforços de Ruggero Jacobbi, tangenciando instâncias partidárias, como se verá adiante, vieram a se somar ao trabalho de muitos. Mas sua atuação individual foi de fato impressionante por sua capacidade de se aliar a quem não se reconhecia nem nos velhos modelos de trabalho teatral nem se enquadrava num padrão de profissionalismo moderno no estilo TBC.

Sua contribuição significativa ajudou a organizar e fortalecer diversos coros de inquietos, sendo ele, em grande parte, o responsável pelo surgimento de um conceito mais avançado de nacional-popular dentro do projeto estético-político do Teatro Paulista do Estudante. 


\section{Capítulo 2}

\section{MOVIMENTOS DO PROJETO “NACIONAL POPULAR”NA VISÃO DE RUGGERO JACOBBI}

Para que se entendam alguns dos aspectos centrais do pensamento artístico de Ruggero Jacobbi sobre a questão do nacional-popular, que viriam a se desenvolver e se modificar no contexto brasileiro, é preciso voltar a seus anos de formação teatral na Itália fascista antes da Segunda Guerra, durante o período em que as diversas especulações sobre o sentido da modernização do teatro estavam atravessadas pela exigência de participação política.

\section{Modernização e resistência na Itália}

Jacobbi iniciou profissionalmente suas atividades teatrais em 1941, durante a guerra, quando dirigiu um espetáculo do GUF (Gruppi Universitari Fascisti). O regime fascista incentivava os jovens a produzirem arte subvencionando sua iniciativa e premiando os melhores resultados no âmbito de uma política cultural que abrangesse toda a Itália. Contudo, contraditoriamente, foi ali dentro de uma estrutura promovida pelo regime fascista que muitos artistas antifascistas como Jacobbi puderam contribuir para um movimento de renovação artística cujo maior expoente foi o Piccolo Teatro di Milano.

A geração de 45 - como ficou conhecida o grupo de jovens teatristas Ruggero Jacobbi, Paolo Grassi, Giorgio Strehler, Gianni Ratto etc. - formou-se no trabalho artístico na prática de grupos amadores e festivais tutelados pelo regime. E foi dentro 
desse aparelho cultural fascista que eles exerceram uma espécie de "resistência" mais ou menos silenciosa que gerou as bases para mais de um projeto de democratização teatral de sentido socialista estabelecidos após a guerra. Alguns deles, mesmo antes da guerra, militavam nas frentes antifascistas (escrevendo em jornais, aderindo aos quadros dos partidos de esquerda) enquanto outros optavam por uma resistência simbólica, cultural. Conheciam e debatiam apaixonadamente textos de Brecht e o Teatro de Piscator. O texto A ópera de três vinténs, de Brecht, que mais tarde teve uma adaptação encenada por Ruggero no Brasil, foi difundido e debatido nesse momento. Os grupos amadores, mesmo ligados ao aparato cultural fascista, encenaram dramaturgos modernos ligados à vanguarda de esquerda, alemã e soviética. O depoimento de Strehler, fundador e diretor do Piccolo Teatro di Milano é revelador nesse sentido:

Certo, La generazione "Del' 45" esiste. Una generazione senza maestri. Questa è una realtà. Andavamo a frugare fra i libri della biblioteca di Nando Ballo, um amico saggio, fra altri, a scoprire da soli Il mondo. Um mondo di cui nessuno ci aveva parlato. Cose false, in gran parte ci avevano detto. Cantavamo L'pera da tre soldi, in segreto, come peccato carnale. [...] Noi volevamo averi maestri. E ci li fabbricavamo, magari [...]. Um meraviglioso período. Meraviglioso perché? Stavamo malissimo. Non avevamo nulla, se non La giovinezza, Che è uma cosa molto importante. Ma non tutto. E avevamo l'ebrietà della giovinezza e l'ebrietà di uma condizione illimitata di speranza. Io li chiamo "i giorni degli eroici furori"

\footnotetext{
${ }^{59}$ STREHLER, G. Per un teatro umano. Pensieri scritti, parlati e attuali, a cura di S. Kessler. Milano: Feltrinelli, 1974, pp. 132-136. "É claro, a geração 'de '45' existe. Uma geração sem mestres. Esta é uma realidade. Fomos para remexer entre os livros da Biblioteca de Nando Ballo, um sábio amigo, entre outros, para descobrir por nós mesmos o mundo. Um mundo do qual ninguém tinha nos falado. Coisas falsas, na maioria das vezes, nos falavam. Cantávamos A ópera de três vinténs, em segredo, como um pecado carnal. [...] Nós queríamos ter professores. E ali os fabricávamos, talvez [...]. Um período
} 
No mesmo ano de 1941, após a experiência no GUF, Ruggero tornou-se assistente do grande teatrólogo italiano Giulio Bragaglia ${ }^{60}$. Um diretor teatral ligado ao futurismo, defensor entusiasta do teatralismo no teatro ${ }^{61}$, para quem o texto era secundário: nem era necessário que o ator entendesse bem o que estava a pronunciar em cena, o importante, para Bragaglia, era a ondulação da voz, da expressão, o movimento da cena propriamente. Com efeito, foi um grande divulgador da comédia renascentista, da retomada modernista da commedia dell'arte, com ênfase na improvisação e na construção de tipos atuais ${ }^{62}$. Bragaglia foi, durante trinta anos, adversário do grande crítico e teórico do teatro moderno italiano, Silvio D’Amico. Segundo Jacobbi, D’Amico não reconhecia o preceito de liberdade da arte que Bragaglia encampava. Por outro lado, Bragaglia, interessado no vínculo entre o velho mundo do teatro italiano e a cena teatralista, era "violentamente hostil à concepção séria, cultural e didática que D’Amico pretendia impor"63.

Entretanto, Silvio D’Amico teria contribuído mais do qualquer outro, segundo Ruggero, para introduzir na Itália o repertório moderno contemporâneo e um conceito de direção teatral com fórmula inspirada em Stanislavski e Copeau, mantendo maior respeito ao texto literário e à poesia. "Para Silvio D'Amico, no teatro in princípio erat verbum $" 64$.

Os ideais de Silvio D’Amico teriam se consolidado na Itália através da Accademia Nazionale d'Arte Drammatica fundada em Roma em 1936 e que formou toda uma geração de atores e diretores nos anos do fascismo como, por

maravilhoso. Maravilhoso, por quê? Nós estávamos péssimos. Não tínhamos nada, se não a juventude, que é uma coisa muito importante. Mas não todos. E nós tivemos a embriaguês da juventude e a embriaguês de uma condição ilimitada de esperança. Eu os chamo de 'dias de fúria heroica"' (livre tradução nossa).

${ }^{60}$ VANNUCCI, A. Missão Italiana. São Paulo: Perspectiva, 2014, p. 6.

${ }^{61}$ JACOBBI, R. Caderno Secreto II, Folha da Noite, 21.1.1954. In: Crítica da razão teatral. São Paulo: Perspectiva, 2005, p. 233.

${ }^{62}$ JACOBBI, R. Les temps difficiles, Ultima Hora, São Paulo, 1952. In: Op. Cit., .202

${ }^{63}$ JACOBBI, R. Silvio D'Amico, Folha da Noite, 12.4.1955. In:

${ }^{64}$ Id. Ibid., p. 225. 
exemplo, Adolfo Celi, que junto com Luciano Salce, criaram a partir da escola o famoso grupo romano A Turma dos Onze. Logo após a guerra, de acordo com Alessandra Vannucci, deflagrou-se uma diferença marcante de posicionamento entre os jovens milaneses (Jacobbi, que se mudara para Milão em 1945, Grassi, Strehler) e os jovens romanos, da Accademia (Adolfo Celi, Luciano Salce, Vitorio Gassman, etc.):

Enquanto os milaneses defendiam a ideia do teatro como política pública, visando o apoio institucional, os romanos cultivavam uma ideia romântica e apolítica da arte. [...] Celi e Salce detestavam qualquer espécie de gregarismo e cultivavam uma ideia de teatro mais romântica e individualista ${ }^{65}$.

A fundação posterior do Piccolo Teatro di Milano decorre desse movimento dos "milaneses", que não haviam estudado teatro em escola como os colegas da Turma dos Onze. Jacobbi, no entanto, sempre manteve profunda admiração por D’Amico. Assim, não é exagero dizer que, por toda a vida, sua prática teatral procurou uma espécie de conciliação entre essas atitudes distintas observadas nos anos de formação: de um lado o teatralismo de Bragaglia, do outro, a atenção ao texto em bases clássicas sugerida por D’Amico.

De todo modo, até a ocupação nazista na Itália em 1943, quando muitos foram presos por subversão, o clima no meio teatral paradoxalmente era festivo. Os jovens viviam um processo contraditório de modernização teatral, com bastante liberdade de criação. Com o fim da ocupação alemã, os artistas voltaram a se encontrar, mas já não havia mais subvenção para os grupos e as academias de teatro, o que só ocorreu antes

\footnotetext{
${ }^{65}$ VANNUCCI, A. Op. Cit., p. 14.
} 
devido à política cultural fascista de instrumentalização da arte. Os jovens enfrentavam com dificuldade o retorno à dependência do mercado. Os empresários voltavam a patrocinar os teatros de estrelas (mattatore e primadonna), para garantir as salas cheias. Essa situação só foi alterada quando os planos de municipalização saíram do papel.

Tempo de nacional popular - Teatro como "serviço público" na Itália

Ao final da guerra, a Itália viveu um tempo de reconstrução. O Partido Comunista Italiano (PCI) saiu muito fortalecido e pela primeira vez tornou-se um partido de massas $^{66}$. Junto com o PSI (Partido Socialista Italiano), na Itália, por exemplo, o PCI ocupou a maioria das cadeiras no parlamento em 1945 e 1946.

Intelectuais, políticos e artistas italianos juntaram-se após a libertação para "repaginar" a história da Itália, para criar as bases de uma nova democracia. O Comitato di Liberazione Nazionale (CLN) - criado com esse intuito - incumbiu Jacobbi, Luchino Visconti e Vito Pandolfi da organização da primeira companhia dramática oficial da Itália democrática.

Em Milão, Ruggero tornou-se critico dramático da revista Film d'Oggi e entrou para o grupo Diogene - do qual participavam Paolo Grassi e Giorgio Strehler - que estabeleceu o estatuto do primeiro teatro estável italiano, o Piccolo Teatro di Milano. Ainda dirigiu com Grassi e Strehler a escola de arte dramática do Fondo Matteorri, nos anos de 1945 e 1946.

\footnotetext{
${ }^{66}$ Até a vitória do nazismo, além da Rússia, a Alemanha foi o único país a ter um partido comunista de massas. Logo após a guerra, segundo o historiador Perry Anderson: “[...] um 'campo socialista' integrado cobria metade do continente. A outra metade foi resgatada para o capitalismo pelos exércitos norteamericano e inglês. Na França e na Itália, contudo, o papel central que os seus partidos comunistas nacionais desempenharam na Resistência converteu-os, pela primeira vez, nas organizações majoritárias da classe operária". (ANDERSON, P. Considerações sobre o marxismo ocidental. São Paulo: Boitempo Editorial, 2004, p. 45).
} 
Em agosto de 1946 encena La voce nella tempesta ( $A$ voz na tempestade), uma adaptação de $O$ morro dos ventos uivantes com produção da Iniziativa Socialista (um grupo pequeno de antisstalinistas coordenado por Mario Zangari e de influência trotskistas), e Alle Stelle, de Leonid Andreiev, considerado o primeiro experimento teatral feito para trabalhadores no pós-guerra.

O importante a destacar é que o mais importante movimento de renovação da cena italiana conseguiu estabelecer no imediato pós-guerra um vínculo entre pesquisa estética e projeto cultural socialista: liderados por Paolo Grassi, o grupo Diogene foi responsável pelo plano de municipalização que veio a formar o primeiro teatro estável moderno da Itália subvencionado pelo governo socialista de Milão. O projeto transformou-se num modelo para outras cidades e possibilitou o ambiente para criação do Piccolo.

Anos mais tarde, em 1954, quando o Piccolo veio em turnê ao Brasil, com diversos espetáculos dirigidos por Strehler, Ruggero escreveu um artigo para Folha da Noite, relembrando aquele contexto de redemocratização na Itália:

Todo o inverno de 1946, em Milão, foi ocupado por um grupo de jovens - grupo pequenino, mas agitado, frenético -, no planejamento e divulgação de uma "política teatral" baseada, em grande parte, na municipalização dos teatros. $\mathrm{O}$ grupinho era conhecido por todos como "o grupo dos quatro". Para a história, diremos que os quatro se chamavam: Paolo Grassi, Giorgio Strehler, Mario Landi e Ruggero Jacobbi. Havia certa atmosfera de ironia e de superior indulgência ao redor dos quatro. Havia, também, hostilidades. Quem não nos chamava de loucos, chamava-nos de sectários. [...] um tempo em que 
era necessário a desforra dos grandes valores espirituais depois da longa treva da ditadura fascista. ${ }^{67}$

Quando o Piccolo foi inaugurado, em 1947, Jacobbi já estava no Brasil. De todo modo, foi o início de um projeto nacional popular público posto em ação na Itália, que exigia como ideal a subvenção estatal para a manutenção de teatros estáveis e populares com elencos fixos e que se apresentassem a baixos custos para a população. O teatro artístico, em contraposição às produções convencionais, era pensado como serviço público, como um bem necessário para a humanidade, assim como são a água e o direito à moradia. Nesse sentido, a ideia de descentralização dos teatros e de "Teatro de Arte para Todos" estavam na essência do projeto (o slogan do Piccolo era: "Teatro d'Arte per Tutti”). Curiosamente, no mesmo momento histórico, Jean Vilar desenvolve na França seu grande projeto de popularização e democratização da cultura. Tanto na França como na Itália a ideia - e o termo - do teatro como "serviço público" foi empregada com obstinação $^{68}$.

\footnotetext{
${ }^{67}$ JACOBBI, R. Folha da Noite, São Paulo, 22.06.1954. In: Crítica da razão teatral. São Paulo: Perspectiva, 2005, p. 209. Alessandra Vannucci escreve em nota que essa crítica de Jacobbi foi publicada na ocasião da vinda do Piccolo para São Paulo, no Teatro Santana. "Em julho-agosto [...] o Piccolo Teatro apresentou: Arlecchino servitore di due padroni, de Goldoni, Il corvo, di Gozzi, La moglie ideale, de Marco Praga, Nostra Dea, de Bontempelli, Um caso clinico, de Buzzati, La giara, de Pirandello, Gioventú malata (Krankeit der Jugend), de Bruckner, Electra, de Sófocles, e Giulio Cesare, de Shakespeare, todos dirigidos por Giorgio Strehler".

${ }^{68}$ Jean-Pierre Sarrazac em seu livro Critique Du Théâtre outorga a Jean Vilar, atento à atuação de seus predecessores Romain Rolland e Firmin Gémier, a introdução, na Europa, da noção de teatro como serviço público, noção esta compartilhada até os dias atuais. O sonho de Vilar consistia em um grande momento de integração popular: "Il s'agit d'apporter à la partie la plus vive de la société contemporaine, aux hommes et aux femmes de tâches ingrates et du sur labeur, les chames d'un art dont ils n'auraient jamais dû, depuis le temps des cathédrales et des Mystères, être sevrés. Il nous faut remettre er réunir dans les travées de la communion dramatique le petit boutiquier de Suresnes et le haut magistrat, l'ouvrier de Puteaux et l'agent de change, la facteur des pauvres et le professeur agrégé" (VILAR, J. Apud SARRAZAC, J-P. Critique du théâtre. Belval: Circé, 2009, p. 35) - "Trata-se de trazer à parte mais viva da sociedade contemporânea, homens e mulheres de tarefas ingratas e de trabalho duro, o charme de uma arte da qual, desde o tempo das catedrais e dos Mistérios, eles não deveriam ter sido jamais separados. Precisamos colocar e reunir nos vãos da comunhão dramática o pequeno balconista de Suresnes e o alto magistrado, o operário de Puteaux e o agente de câmbio, o carteiro dos pobres e o professor adjunto" (tradução nossa).
} 
O Piccolo procurava oferecer a preços populares grandes produções experimentais de teatro. Recuperou um interesse pelo teatro popular tradicional italiano (Goldoni, Gozzi), mas encenou também Shakespeare, Molière e outros autores centrais do teatro moderno europeu, com particular interesse por Brecht. Um teatro que atendesse a todos. Paolo Grassi, no artigo Teatro, pubblico servizio, que escreveu para a revista socialista Avanti, em abril de 1946, fez a seguinte afirmação:

il teatro, per la sua intrinseca sostanza, è fra le arti la più idonea a parlare direttamente al cuore e alla sensibilità della collettività, $[\ldots]$ il teatro è il miglior strumento di elevazione spirituale e di educazione culturale a disposizione della società. Noi vorremmo che autorità e giunte comunali, partiti e artisti si formassero questa precisa coscienza del teatro, considerandolo come una necessità collettiva, come un bisogno dei cittadini, come un pubblico servizio, alla stregua della metropolitana e dei vigili del fuoco, e che per questo preziosissimo pubblico servizio nato per la collettività, la collettività attuasse quei provvedimenti atti a strappare il teatro all'attuale disagio economico e al presente monopolio di un pubblico ristretto $[\ldots]^{69}$.

O Piccolo deveria ser, enfim, um teatro de arte para todos, congregando grupos sociais diferentes. E o repertório teria de refletir isso. Ainda que de início o público não tivesse efetivamente se expandido, a ideia era aproximar trabalhadores, estudantes etc.

\footnotetext{
${ }^{69}$ GRASSI, Paolo. Teatro, pubblico servizio. Avanti!. 25 aprile 1946 "O teatro, por sua própria essência, é entre as artes a mais adequada para falar diretamente com os corações e sentimentos da comunidade, [...] o teatro é a melhor ferramenta para a elevação espiritual e educação cultural disponível para a empresa. Nós gostaríamos de ver as autoridades e os conselhos municipais, os partidos políticos e artistas formarem essa consciência precisa do teatro, vendo-o como uma necessidade coletiva, como uma necessidade do cidadão, como um serviço público da mesma maneira que o são as linhas do metrô e o Corpo de Bombeiros, e por este valioso serviço público criado pela comunidade, a comunidade implementasse medidas para arrancar o teatro do atual mal-estar econômico e do presente monopólio de uma audiência limitada" (tradução nossa)
} 
O objetivo era formar um novo repertório, um novo público e também um novo estilo de atuação ${ }^{70}$.

Numa Europa destruída pela guerra, mas com um Partido Comunista com alcance de massa, as artes deveriam tomar de volta a tradição popular italiana que havia sido disputada pelo imaginário nacionalista dos tempos fascistas. A ideia de teatro moderno para Ruggero estava assim significativamente ancorada nas experiências que viveu. Ao mesmo tempo, ele elaborou tudo isso de forma muito própria e com alta sensibilidade para as especificidades que encontrou no Brasil, em que os processos culturais eram diversos.

\section{Influência de Gramsci e a aclimatação do nacional-popular}

Em sua visão de teatro existem, portanto, muitas influências. De um ponto de vista não apenas teatral, é importante mencionar que sua reflexão - como a de muitos de sua geração - está atravessada pelo diálogo notável com a obra do intelectual comunista Antonio Gramsci ${ }^{71}$. Jacobbi articulou e trabalhou diretamente com o conceito de nacional popular desenvolvido por Gramsci na Itália $^{72}$. Em um período no qual o comunista italiano era provavelmente pouco conhecido pelos brasileiros, suas ideias

\footnotetext{
${ }^{70}$ Cf. HIRST, D. L. Giorgio Strehler. Birmingham: Cambridge University Press, 1993, p. 6.

${ }^{71}$ Como se sabe, Gramsci ficou preso durante quase todo o período fascista e morreu em decorrência disso. Durante seu encarceramento, o líder comunista italiano escreveu longas reflexões sobre política, economia e cultura, sobre a história italiana. Morreu em 1937, mas seus cadernos do cárcere só são publicados a partir de 1948, na Itália. Depois, portanto, da inauguração do Piccolo e da vinda de Ruggero para o Brasil. Após esse período, certamente os intelectuais italianos, assim como os franceses, tiveram acesso a seus escritos e foram influenciados por eles. Mas mesmo antes das edições dos Cadernos suas ideias circulavam com grande influência pela esquerda intelectual na Itália.

${ }^{72}$ Em 1955 Ruggero deflagra literalmente a grande influência de Gramsci para a definição do conceito de nacional popular, em texto sobre Schiller e Gonçalves Dias, publicado posteriormente (1958) no livro Goethe, Schiller, Gonçalves Dias. Ali Ruggero comenta que a tradução de Gonçalves Dias de A Noiva de Messina, de Schiller, "correspondia a certo indisfarçável interesse de Gonçalves Dias por aquela concepção da poesia que, com termos de Gramsci, chamarei "nacional-popular". A tragédia de Schiller, ainda que não escondesse a vontade de restauração da "forma antiga" (tragédia), revelava ambições "de ordem não apenas literária", como percebido pela "tentativa de reconduzir o coro à sua função de presença coletiva dentro do drama”. (JACOBBI, R. Goethe, Schiller, Gonçalves Dias. Porto Alegre: Edições da Faculdade de Filosofia, 1958, p.42).
} 
com relação à cultura entraram com força no país por meio de Ruggero. Mais que isso, foram, de algum modo, os fundamentos gramscianos de algumas de suas proposições que abririam caminhos para alguns do momentos mais engajados do teatro nacional das décadas de 1950 e 1960 a partir da junção do Teatro Paulista do Estudante com o Teatro de Arena de São Paulo.

Na experiência que viveu com as ocupações de Fábrica em Turim, entre 1919 e 1920, Gramsci observou que um dos motivos para que aquele movimento importante não tomasse maiores proporções foi a falta de identificação entre os operários das diversas partes da Itália, algo que pudesse ajudar na criação de redes de apoio, sendo notável os vínculos fracos entre operários (predominantemente do norte) e camponeses (do sul). A partir dessa experiência Gramsci compreendeu a necessidade de se criar uma cultura comum que identificasse camponeses e operários, o povo do norte e do sul do país. Esta gradual mudança e constituição para uma nova mentalidade tomaria parte na superestrutura, alcançando o conjunto da sociedade civil. Os proletários e camponeses deveriam criar e recuperar uma cultura comum, nacional popular, capaz de se tornar hegemônica $^{73}$, que contribuísse para direção e mesmo dominação das outras classes dentro de um processo revolucionário ${ }^{74}$.

Gramsci é, portanto, um intelectual e militante empenhado, para usar a terminologia de Antonio Candido ${ }^{75}$, em criar as condições para outro tipo de modernização, que fosse construída de baixo pra cima, pelas camadas populares e pelos

\footnotetext{
${ }^{73}$ De acordo com Lincoln Secco, o conceito de hegemonia é dinâmico. É necessário verificar a noção ligada aos contextos históricos e análises de conjuntura. Hegemonia para Gramsci (pois o sentido de hegemonia varia no marxismo contemporâneo) pressupõe uma direção e um domínio. Ela é a capacidade de uma classe (grupo ou partido) de dirigir segmentos sociais. (SECCO, L. Gramsci e a revolução. São Paulo: Alameda Editorial, 2006).

${ }^{74}$ GRAMSCI, A. Os intelectuais e a organização da cultura. Rio de Janeiro: Editora Civilização brasileira, 1968.

${ }^{75}$ Cf. CANDIDO, A. Formação da literatura brasileira. 10ª ed. Rio de Janeiro: Ouro Sobre Azul, 2006.
} 
intelectuais a elas ligados. A ideia seria partir de modelos culturais progressistas que auxiliassem na construção de uma cultura nacional popular própria.

A posição de Ruggero sobre teatro moderno articulava a seu modo, portanto, um campo crítico e poético que pode ser denominado como nacional popular. Isso vem a se configurar num projeto estético-político de sentidos variados (conforme o momento de sua vida teatral) quando seu trabalho prático se desenvolve no Brasil.

Nos anos em que passou por aqui, as várias frentes de atuação do diretor italiano sempre gravitaram em torno dessa categoria, seja no interesse pela matéria específica do país; na escolha de repertório com temas ligados aos explorados; na proposição de formas populares de fundamento antiburguês consideradas "rebaixadas"; no trabalho por condições de produção e de circulação subvencionadas pelo Estado que fomentassem um teatro democrático e verdadeiramente popular para além dos centros produtores de cultura; no empenho, enfim, pela construção de um sistema articulado para o teatro brasileiro moderno voltado para o conjunto social.

Ruggero trouxe para cá a experiência e a postura política elaboradas na Itália como resistência e reconstrução democrática. A atenção, contudo, que ele dava ao Brasil fez com que sua abordagem do projeto fosse diversa, toda própria. Aqui Jacobbi organizou uma síntese particular das influências europeias e tentou fazê-las operar com vitalidade na periferia do mundo.

\section{Nacional x nacionalismo}

Para Jacobbi, o índice de maturidade de um movimento teatral estaria na combinação de um repertório nacional a uma reinterpretação dos clássicos mundiais. A modernização só se completaria quando um conjunto estivesse em funcionamento, 
numa relação interligada entre autores, encenadores nacionais e o grande público. Nesse sentido, seu pensamento se aproxima de uma certa ideia de formação tal como elaborada por Antonio Candido ${ }^{76}$. Jacobbi, assim, foi militante ativo de uma proposta de interação de campos que pudesse criar condições de um melhor desenvolvimento entre o trabalho de uma cena moderna e de uma dramaturgia nacional, sendo um dos eixo centrais desse processo um tipo de atuação que levasse em conta a consciência dos nossos “brasileirismos”. Em 1958 Ruggero diz:

Um teatro sem autores próprios, um teatro que vive de traduções e adaptações, pode ter os maiores atores, encenadores e cenógrafos deste mundo, mas sua palavra terá sido escrita na água, na areia e no vento.

\footnotetext{
${ }^{76}$ Em a Formação da literatura brasileira (Rio de Janeiro: Ouro Sobre Azul, 2006), Antonio Candido "reconstitui", em suas próprias palavras, a história dos brasileiros quanto ao desejo de terem uma literatura. $\mathrm{O}$ autor explica que desde a chegada dos portugueses ao Brasil existiu literatura, mas não de maneira sistemática, de modo a fomentar a vida literária. Além disso, não houve o estabelecimento de uma tradição e, em suas palavras, "sem [...] tradição não há literatura, como fenômeno de civilização" (p. 26). Com isso, Antonio Candido distingue o sentido de manifestação literária de literatura, a qual pressupõe um sistema articulado, que depende do tripé "autor-obra-público" em "interação dinâmica e de uma certa continuidade da tradição" (p.17). Antonio Candido usa da noção de tradição elaborada por T. S. Eliot. Mas o autor norte americano trata idealmente do assunto, retirando da matéria estudada sua bagagem histórica. Para Eliot, "toda a literatura europeia desde Homero [...] têm uma existência simultânea" (ELIOT, T. S. Tradição e talento individual. In: Ensaios. São Paulo: Art Editora, 1989, p. 39). Com Antonio Candido as questões levantadas por Eliot são colocadas no plano concreto, postas a serviço de uma ideia de nação. É possível afirmar que, de certa forma, Candido subverte o pensamento canônico de Eliot, ao recolocar a noção de tradição na periferia do capitalismo, que é o Brasil. Assim, o caráter conservador universalista de Eliot é reconfigurado, ao entrar em contato com o particularismo que Antonio Candido identifica na literatura brasileira. Com efeito, ao procurar a tradição em terras brasileiras, Candido inverte o sentido potencialmente reacionário da noção de tradição em Eliot - que não levaria em conta as tradições locais, mais pobres e recentes - e, ao fazê-lo, coloca em dúvida a própria noção de universalidade. A tradição ao mesmo tempo local e cosmopolita é novidade enquanto expressão de um país em formação. Esse achado de Antonio Candido abre as portas para uma verdadeira transformação na leitura sobre o Brasil pela intelectualidade nacional, pois, como explica o crítico cultural Roberto Schwarz: "Num país culturalmente a reboque, como o nosso, onde as novidades dos centros mais prestigiosos tem efeito ofuscante, a exigência de um conjunto de obras entrelaçadas, confrontadas entre si, lastreadas de experiência social específica, ajuda a barrar a ilusão universalista que é da natureza da situação da leitura, ilusão a que é levado todo leitor, especialmente quando, com toda a razão, busca fugir à estreiteza ambiente" (SCHWARZ, Roberto. Sequências brasileiras. São Paulo: Companhia das Letras, 1999, p. 20). Às noções de sistema articulado e tradição, Antonio Candido acrescenta a de empenho, que seria um traço particular de nossa literatura, voltada "para a construção de cultura válida para o país" (p.20). Os escritores contribuem e se inscrevem "num processo histórico de elaboração nacional" (p. 20), característica dos países recentemente fundados. Para o crítico, trata-se de uma "circunstância que inexiste nas literaturas dos países de velha cultura. [...] Nelas não há a consciência, ou a intenção, de estar fazendo um pouco de nação ao fazer literatura" (p.20).
} 
Esse teatro há de ser nacional. Igualmente, um teatro que se dirige apenas a uma minoria social, que não chega a enfrentar o verdadeiro povo - e não apenas como diversão, mas como maneira de preencher uma função ética, cívica, coletiva, também seria um teatro de alcance limitado, sujeito a todos os perigos literários e morais. Esse teatro, pois, há de ser popular ${ }^{77}$.

$\mathrm{Na}$ visão de Ruggero, a dramaturgia nacional do passado seria útil para a consolidação da cena atual, que precisaria voltar-se para a história a fim de compreender o presente e criar uma tradição. Isso não significaria de modo algum um olhar conservador para o palco. Era categórico ao afirmar que um autor só se consagra se estiver conectado com o "espírito de sua época". Cabia sempre verificar a atualidade possível de uma obra, por isso postulava a necessidade de montar os clássicos do passado. Afinal não se tratava de "dar vida a coisas mortas, mas de ver se ainda estão vivas."78

Na perspectiva de uma nova fase para o teatro nacional, Ruggero empenhou-se em tirar do limbo autores àquela altura pouco encenados, em sua maioria do período romântico. Seu critério era a capacidade das obras revelarem, em alguma medida, uma consciência crítica sobre o desenvolvimento social do país, o que se vê em Martins Pena, Machado de Assis e Gonçalves Dias. Pela consciência de deslocamento em relação ao centro da ideologia hegemônica, liberal e burguesa foram escritores de teatro que revelaram, com maior ou menor qualidade ou consciência, a própria falácia dessa ideologia burguesa ${ }^{79}$.

\footnotetext{
${ }^{77}$ JACOBBI, R. O teatro de Machado de Assis. Correio do Povo, Porto Alegre, 11.10.1958. In: Crítica da razão teatral. São Paulo: Perspectiva, 2005, p.167.

${ }^{78}$ Id. Ibid., p. 95.

${ }^{79}$ Roberto Schwarz em As ideias fora do Lugar, afirma que: "no Brasil as ideias estavam fora de centro, em relação ao seu uso europeu. [...] para analisar uma originalidade nacional, sensível no dia-a-dia, fomos
} 
Essa volta ao passado parece indicar um propósito militante de construção futura, de criação das condições básicas para modernização, que ainda não estavam dadas, pois o projeto de uma "cultura nacional" mesmo burguesa também não havia se completado. Por sugestão de Ruggero Jacobbi foram encenadas peças de Martins Pena, Gonçalves Dias, Machado de Assis e J. Manuel de Macedo no IV centenário da cidade de São Paulo (1953-1954). Também por sua indicação Adolfo Celi dirigiu Leonor de Mendonça no TBC, em $1954^{80}$.

O interesse de Jacobbi por uma peça como Leonor de Mendonça é exemplar desse empenho de comprometimento, comum a outros artistas engajados do período, com as questões nacionais. Gonçalves Dias foi um poeta que se pensou como participante de uma tradição, pois retoma o passado árcade ${ }^{81}$ e fornece aos sucessores o modelo. A escola literária que predominava na Europa em 1840 era o Romantismo, que aparecia a muitos de seu tempo como o caminho favorável para a expressão da pátria que acabara de ser fundada, pois primava pela afirmação do particularismo e da identidade, o que contribuía, em larga escala, para criar uma base original e nacional em oposição a Portugal.

Ruggero Jacobbi considera Leonor de Mendonça uma obra prima, “cujo prefácio precisaria figurar entre os mais lúcidos manifestos do teatro romântico mundial"82. Este prefácio é um longo texto com 38 tópicos, escrito na ocasião da publicação da peça,

levados a refletir sobre o processo da colonização em seu conjunto, que é internacional. O tic-tac das conversões e reconversões de liberalismo e favor é o efeito local e opaco de um mecanismo planetário.". (SCHWARZ, R. As ideias fora do lugar. In: Ao vencedor as batatas. São Paulo: Duas Cidades/Editora 34, 2008)

${ }^{80}$ Leonor de Mendonça já havia sido encenado por Esther Leão, em 1939, no Teatro do Estudante, de Paschoal Carlos Magno. (REVISTA DIONYSOS. Rio de Janeiro: MEC-SNT, nº 23, set. de 1978)

${ }^{81}$ Antonio Candido destaca como marco inicial da Formação da Literatura Brasileira os árcades e os românticos, vistos até então como antagônicos. (CANDIDO, A. Op. Cit., 2006.)

${ }^{82}$ JACOBBI, R. Goethe, Schiller, Gonçalves Dias. Porto Alegre: Edições da Faculdade de Filosofia, 1958, p. 41. O livro publicado em 1958, pela Universidade do Rio Grande do Sul, onde Ruggero lecionava, reuniu textos escritos por Ruggero desde 1955, a respeito dos destacados autores românticos. Sábato Magaldi considera a obra o mais importante estudo sobre Gonçalves Dias já escrito. 
após João Caetano ter se recusado a montá-la ${ }^{83}$ Semelhante ao prefácio de Cromwell (1827) de Victor Hugo, segundo Ruggero Jacobbi, demonstra de fato uma lucidez impressionante e vislumbra-se nele, além da defesa do Romantismo, o empenho por uma expressão coletiva de uma cultura de tipo nacional através da literatura. Ruggero viu no prefácio o esforço de Gonçalves Dias em criar as condições para uma dramaturgia nacional, exemplo da dialética entre universal e particular. Isso porque Gonçalves Dias ao mesmo tempo em que revelou seu conhecimento íntimo da mais alta literatura mundial de seu tempo, assumiu um compromisso com o desenvolvimento da dramaturgia local, com as questões linguísticas e mesmo temáticas do país, ainda que a peça se passasse em Portugal: "Nenhum escritor brasileiro do século passado teve tanta e tão límpida consciência da própria situação dentro da cultura mundial”"84.

No prefácio, Gonçalves Dias destrinchou a própria dramaturgia, como se abrisse ao público o mecanismo de criação da peça, colocando suas escolhas em debate e assumindo as impossibilidades de realização de algumas delas, por causa do "atraso" nacional $^{85}$. Isto significava, aos olhos de Ruggero, que o poeta do século XIX ao fomentar a criação de uma tradição da literatura dramática brasileira, também criou um modelo capaz de servir de inspiração aos próximos que viriam. Além disso, Gonçalves Dias distinguia a obra literária de sua dimensão cênica, aludia "à necessidade, que as pessoas têm, de passarem do livro para o palco" ${ }^{\text {86 }}$. Seria necessário, pois, que um sistema estivesse em funcionamento para que as artes cênicas se completassem, articulando, como definiu Antonio Candido, autor, obra e público. Segundo Jacobbi:

\footnotetext{
${ }^{83}$ Nenhuma de suas peças foi encenada em vida e, por um motivo ou outro, algumas foram censuradas pelo Conservatório Dramático Brasileiro. Leonor de Mendonça, que fora aceita, não subiu ao palco pois João Caetano, o ator que "comandava" a cena brasileira, não quis saber dela.

${ }^{84}$ JACOBBI, R. Op. Cit., 1958, p.73.

${ }^{85}$ DIAS, A. G. Teatro completo. Rio de Janeiro: Serviço Nacional de Teatro, 1979, p. 60

${ }^{86}$ Id. Ibid., p. 67.
} 
Aqui a certeza de que o drama só se revela na representação transforma-se em imperativo ético: o pensamento livre deve ser patrimônio comum de um povo livre, matéria de debate, encontro ritual de uma sociedade, e não simples deleite de leitores solitários. ${ }^{87}$

De acordo com Ruggero Jacobbi, a fatalidade que aparece na trama de Leonor de Mendonça $a^{88}$ não é fruto de determinações divinas, mas humanas, atrelada às condições históricas. Gonçalves Dias estaria empenhado em revelar o caráter fixo, enrijecido, da condição da aristocracia em oposição à mobilidade típica da burguesia, valorizando esta em detrimento daquela.

Essa discussão estava em dia com as novidades advindas das revoluções burguesas em curso na Europa. O teatro de Gonçalves Dias, em específico Leonor de Mendonça, e particularmente seu prólogo, parece representar um momento de esforço explícito na tarefa de incorporar por um lado, "o conjunto da vida nacional” e por outro os temas e formas da cultura contemporânea. Ainda que não apareça o espelhamento

\footnotetext{
${ }^{87}$ JACOBBI, Ruggero. Goethe, Schiller, Gonçalves Dias. Porto Alegre: Edições da Faculdade de Filosofia, 1958. P.78

${ }^{88}$ Leonor de Mendonça (1846) é uma das quatro peças de Gonçalves Dias e é considerada sua obra prima No livro Teatro no Brasil, Ruggero Jacobbi comenta minuciosamente o argumento do drama. Trata-se de uma história retirada de uma crônica medieval portuguesa (muito ao gosto do poeta). A ação se passa em Vila Viçosa, lugar afastado da cidade, onde Dom Jaime "mantém uma legião" e arrasta para lá sua jovem esposa Leonor, pouco acostumada à vida campestre. Eles têm dois filhos, mas "não se pode dizer que Leonor é realmente mulher de Dom Jaime". Uma "rainha inútil", que só se relaciona com sua serva, "pronta para se tornar a qualquer momento uma escrava". O Duque a trata mal como se ela tivesse culpa por ele ter se casado contra a vontade, quando sua vocação era para padre. "Jaime é um verdadeiro monstro". Atormentado pelas lembranças trágicas de seu passado, é severo e cruel com todos ao seu redor. Jacobbi o compara às personagens de Marlowe, "por sua complexidade psicológica", mas pondera que Gonçalves Dias, diferente do autor inglês, mantém distância da personagem, "sem identificar-se com ele como faria um ator expressionista; antes com a lucidez de um clássico, ou melhor, de um realista" (JACOBBI, R. Teatro no Brasil. São Paulo: Editora Perspectiva, 2012, p.138). Estão tramadas, assim, as circunstâncias de uma inevitável tragédia. A relação entre Leonor e Dom Jaime é inspirada em Otelo, de Shakespeare: "Gonçalves Dias era o primeiro a saber disso e, no prefácio da obra, toma o cuidado de esclarecer, com extraordinária consciência crítica, o que deve a Shakespeare, bem como no que se distancia”. (Id. Ibid., p.138) - lembra Ruggero. A principal diferença seria a ausência de amor entre as personagens do drama brasileiro, assim como a ausência da traição de fato. Leonor é inocente, apesar de se encantar pelo Alcoforado (subordinado do Duque). A vingança do Duque seria, ainda na visão de Ruggero, um pretexto para "detonar" seu ódio. Ele assassina o Alcoforado e Leonor. E Leonor buscaria "o espanto", de si própria, de seu marido algoz e do público, por ser condenada injustamente. No último ato, quando condenada, ela luta com as palavras para viver.
} 
mútuo e verificador das relações próprias ao Brasil, salta à vista o empenho em criar as condições para uma literatura atualizada e voltada ao país.

Jacobbi, como Antonio Candido, percebeu no trabalho de Gonçalves Dias - no período romântico brasileiro, de modo geral - uma atitude nova, uma disposição em olhar criticamente para aquilo que é brasileiro, a partir de uma assimilação e apropriação de modelos europeus.

Como seus parceiros no Piccolo, Ruggero incentivava a retomada desse teatro nacional romântico em chave materialista e histórica, procurando iluminar o possível interesse atual daqueles textos. O que mais interessava ele nessas peças era o seu paradoxal "realismo" e a tentativa de dar voz e sentido a um sentimento coletivo. Interessava recuperar para a modernidade o sentido coletivizante do projeto dos românticos. Tratava-se, portanto, de um nacionalismo relativo. Importava antes o fato de ser teatro feito de atitude brasileira (o que não se resume à temática), que procurasse refletir questões pertinentes ao povo brasileiro e que se dirigisse a esse povo.

Em Literatura e vida nacional, Antonio Gramsci investiga e analisa diversos aspectos da cultura nacional italiana, das condições necessárias para a formação de uma cultura nacional popular, de elementos de cultura de massa (como os romances de folhetim). Analisa ainda diversos autores cuja obra ele considera nacional popular, e desses apenas dois são italianos, Goldoni e Maquiavel. Outros citados são: Tolstoi, Molière, Shakespeare, Dostoievski, Schiller etc. ${ }^{89}$.

\footnotetext{
${ }^{89}$ Para Gramsci: "a ausência de uma literatura nacional-popular, devida à ausência de preocupações e de interesse por estas necessidades e exigências, deixou o 'mercado' literário aberto ao influxo de grupos intelectuais de outros países, que - 'populares-nacionais' em sua pátria - também o foram na Itália, dado as exigências e necessidades que buscavam satisfazer são similares também na Itália” (GRAMSCI, A. Literatura e vida nacional. Rio de Janeiro: Editora Civilização brasileira, 1968, p.18). Gramsci aborda autores "universais", nacionais populares, que poderiam servir de modelo para a formação de uma literatura nacional popular na Itália, autores como Tolstoi, Shakespeare, Dostoievski. A mesma literatura que Ruggero considera como universal.
} 
Gramsci analisou alguns aspectos dessas obras estrangeiras nacionais populares e percebe nelas o que ele chama de um "universalismo popular" marcado por um sentimento antiburguês. Seria necessária para a construção dessa cultura popular uma busca pelo realismo, pelo sentido universal da representação. Universal entendido como popular, que no fundo é a busca pelo social, pelo histórico e objetivo. Segundo Cláudio Reis, comentando tais conceitos na obra de Gramsci:

A "universalidade" do artista, na leitura gramsciana, passa necessariamente por uma incorporação/expressão daquilo que é mais concreto e historicamente vivo, quer dizer, daquilo que impulsiona a própria história. Neste sentido, ele não pode deixar de ser "nacionalpopular", pois é a partir desta dimensão que será possível captar profundamente o "movimento" de determinada época histórica. [...] Além do mais, o surgimento de uma nova literatura somente se concretizará quando ela estiver profundamente nacionalizada, em toda a sua complexidade ${ }^{90}$.

É nesse sentido que Ruggero Jacobbi em artigo sobre a Quinta Bienal de São Paulo, em 1959, traça uma distinção entre "cosmopolitismo" e "internacionalismo". O cosmopolitismo seria uma negação da história. É a crítica que faz à nova vanguarda neoconcreta. Para ele, esta fase da pintura, "que deveria ser o triunfo da liberdade criadora":

[...] determina, ao contrário, um panorama monótono, uniforme e cheio de repetições, no qual não apenas as características nacionais

\footnotetext{
${ }^{90}$ REIS, C. O Nacional Popular em Antonio Gramsci. 2009. Tese (Doutorado em Ciências Sociais) Instituto de Filosofia e Ciências Humanas, Universidade Estadual de Campinas, Campinhas, 2009, p. 374.
} 
são canceladas em prol de uma linguagem de exportação, mas - o que é mais grave -, até mesmo os valores de personalidade, os mundos poéticos e estilísticos irredutíveis, dissolvem-se e dispersam-se ${ }^{91}$.

A ideia de arte internacional, portanto, deve se opor ao caráter de autonomização das artes no sistema mercantil; à linguagem feita para exportação; ao cosmopolitismo de fachada. Ela deve, sim, advir de um processo moderno de universalização (internacionalização) como fruto de uma difusão das culturas. Só assim seria possível o surgimento de uma "expressão do drama coletivo de uma civilização, cujas premissas (passado), problemas (presente) e esperanças (futuro), assemelhavam-se cada dia mais." Esse mesmo procedimento internacionalizante, dialeticamente, forçaria a uma volta ao particular, à “eclosão do elemento nacional popular" 92 . Essa apropriação dos conceitos de cosmopolitismo e internacionalismo (ou universalismo) oferece uma boa imagem da permanência das ideias gramscianas no pensamento teatral de Ruggero Jacobbi.

\section{Por um Teatro Popular}

O conceito de teatro popular para Ruggero Jacobbi assumiu diversos sentidos. Acima de tudo significava um teatro que deveria "dirigir-se ao povo", estar aberto "às grandes massas". Mas isso não significava apenas uma ênfase no acesso de um público popular ao teatro. Popular seria um teatro que cumprisse uma função de debate público, que participasse da prática da vida, do mundo do trabalho, e que para isso falasse sobre os homens reais, sobre as relações entre homens reais (o que o levaria a ser também, inevitavelmente, nacional). Trata-se de um espírito realista - menos nos sentido do

\footnotetext{
${ }^{91}$ JACOBBI, R. Pintura cosmopolita. Correio do Povo, Literária, 7.11 .1959 (Série: A Quinta Bienal de São Paulo). In:

${ }^{92}$ Id. Ibid., p. 138. Crítica da razão teatral. São Paulo: Perspectiva, 2005, p. 138.
} 
estilo histórico e mais como atitude representacional de um humanismo clássico. Um realismo aberto a todas as formas, tantos as farsescas como as trágicas. A questão de fundo dessa atitude popular era sua necessidade de ser antiburguês, "antipsicológico por definição", ou pelo menos "antianalítico"93.

Poderíamos, então, assistir ao milagre da palavra poética que corre de boca em boca, [...] poderíamos assistir às tremendas festas da liberdade, quando o destino dos homens é debatido por eles mesmos, face a face, sem mentiras, no jogo franco das consciências individuais estimuladas pelo sentimento de solidariedade coletiva contra a destruição. [...] Poderíamos ver o que é uma noção aberta de liberdade; liberdade como sistema, como criação e reconhecimento de valores. $^{94}$

Para Jacobbi, o reino da burguesia estava inevitavelmente abalado, numa crise sistêmica, endêmica. Para ele, os países nos quais a ideologia burguesa está mais entranhada, por motivos distintos, são aqueles que produzem também as peças que mais satirizam e ironizam seu sistema ideológico, revelando cruelmente as mazelas e decadência dessa mesma sociedade. No limite, são figurações da crise da forma burguesa, da crise sistêmica do próprio capitalismo. Segundo ele:

No século passado, a burguesia produziu farsas e sátiras no seu lugar básico de afirmação e de irradiação: na França. Em nosso século, outra fonte inesgotável de comicidade elementar veio acrescentar-se à primeira, com espírito e técnica especiais: o humor anglo-saxônico.

\footnotetext{
93 JACOBBI, R. Horizontes do teatro, 1955 In: Educação e Cultura/Instituto Nacional do Livro, 1956, p. 193. . A expressão dramática. São Paulo: Ministério da ${ }^{94}$ Id. Ibid., p. 195.
} 
Hoje em dia, uma sociedade inteira aprende a rir de si mesma, contemporaneamente através das peças produzidas seja pelo país em que é mais aguda sua crise moral e cultural (França), seja pelo país que defende, mais tenazmente, os seus valores tradicionais (Inglaterra), ou seja pelo país que representa a sua última esperança de consolidação econômica (Estados Unidos) ${ }^{95}$.

Com efeito, para Ruggero, a crise do capital e do mundo burguês (decorrente de sua própria realização) fomentava, dialeticamente, um tipo de teatro que superaria as formas estéticas desse mesmo mundo burguês.

Não por acaso, portanto, Ruggero encampou uma luta constante em defesa de repertórios populares, farsescos, satíricos. É interessante notar, portanto, que o projeto de modernização nacional popular de sentido antiburguês, tal como entendido por Jacobbi, surgia, nas condições do Brasil do pós-guerra como crítico de certo elitismo esteticista que surgia como tendência da "nova vanguarda" (principalmente pós-1945 na Europa) e que em muitos casos se encaminhava para uma estetização da arte, dissociando-se assim do próprio projeto modernista anterior.

Acreditamos no métier teatral, no valor social da sátira, na utilidade documentária das comédias que nascem da observação ou da utilização de nossa vida de últimos burgueses sobre a terra. Desconfiamos radicalmente de todo teatro que - com a desculpa da "eternidade" e dos valores metafísicos - procura disfarçar a sua incapacidade de criar personagens, de construir enredos, de manifestar um ponto de vista a respeito dos homens atuais: não do Homem, que

\footnotetext{
95 JACOBBI, R. Camas gêmeas, cadáveres vigaristas. Folha da Noite, São Paulo, 6.11 e 7.11.1952. In: Crítica da razão teatral. São Paulo: Perspectiva, 2005, p. 26.
} 
não existe, mas dos homens, de vocês, de nós, de beltrano, limitados e condicionados pelos anos, pelas classes. Uma boa metade do teatro de boulevard é honesta. Três quartos do teatro de poesia são desonestos. $[\ldots]$

Eis aqui a nossa heresia-mor: parece-nos que a arte, qualquer arte, ainda é uma relação direta entre um homem e uma realidade. Homem histórico, realidade concreta - está dito. Atirem-nos pedras. Oh, brave New World W6 $^{96}$

Para ele, as primeiras vanguardas (futuristas, dadaístas, surrealistas) eram cheias de vidas, cheias de "afirmações vitais", de uma revolta "alegre" contra aquele estado de coisas, contra a vida burguesa, eram os ecos da primeira guerra mundial. Aquele espírito vanguardista irreverente e vivo transformou-se na negação abstrata e "gélida" dos vanguardistas contemporâneos. A irreverência destrutiva da primeira vanguarda tornase mistificação estetizada, na visão de Ruggero:

Os vanguardistas de hoje guardam, daquela experiência, a componente libertária que, porém, já se tornou niilista e (o que é pior) vagamente mística. Os mitos da revolta, reduzidos pelo surrealismo à reivindicação do mundo subconsciente contra o mundo real (l'existence est alleurs) transformam-se, agora, em negação isolada e gélida, abstração e renúncia. ${ }^{97}$

Ele acreditou que essa retomada vanguardista da guerra fria era sintoma de um "romantismo decadente" que tomava a crise pelo fim do mundo, que considerava o

\footnotetext{
${ }^{96}$ JACOBBI, R. Heresia em dó maior, jornal Última Hora, s/d, 1952. In: Op. Cit., p. 9.

${ }^{97}$ JACOBBI, R. Folha da Noite, São Paulo, 20.7 e 21.07.1955. Apresentação e crítica da peça Esperando Godot, de Beckett, pela EAD-SP, dir. Alfredo Mesquita, julho de 1955. In: Op. Cit., p. 187.
} 
estado das coisas como imutável, como absoluto. O materialismo histórico de Ruggero aqui é decisivo. Para ele, o niilismo de um Beckett, da música dodecafônica, da pintura concreta traziam "esse sentido de fim de linha", mas no fundo tratava-se de uma eternização do mundo dado, uma descrença na possibilidade de o homem se refazer e se autodeterminar.

É sempre o velho engano do romantismo decadente: tomar por universal e absoluto aquilo que é apenas sentimento de insegurança, constatação de mistérios, espanto e dor perante a injustiça. É o velho engano daqueles que pensam que o homem, no fundo, é imutável, e que os destinos se repetirão por lei natural e por maldição. É a tentação da eternidade, essa grande inimiga da vida e da autodeterminação dos homens. ${ }^{98}$

O mundo burguês, para Ruggero Jacobbi, estaria com os dias contados, o que não significava que seu campo ideológico fosse facilmente superado. Ruggero apresentava uma consciência crítica da limitação ideológica determinada pela classe, pelo seu tempo. Em sua visão, os escritores "mais fracos" muitas vezes sofriam de “autocompaixão de classe" e não conseguiam tomar conhecimento da sociedade humana, da "nossa ligação com a realidade, com a história". Só que por mais que não enxergassem sua inscrição, todo este mundo (seus jornais, teatros e filmes) estaria destinado "aos ratos" e "aos vermes". Ele próprio reconheceu a dificuldade de ultrapassar o elitismo de sua classe. Afinal, ele e seus pares pertenciam "à delicada

\footnotetext{
${ }^{98}$ Id. Ibid., p. 187. Mais uma vez coincidem as escolhas estéticas com as de seu contemporâneo, Jean Vilar, que teria deixado de fora de sua renovação o teatro feito no pós-guerra propriamente. A perspectiva desses teatros estatais realmente pareciam opostas ao niilismo exposto em boa parte da literatura contemporânea. Interessava para o nacional popular uma dramaturgia que mostrasse o homem em transformação e que mesmo diante do aparente caos, a ideia de que aquilo também era histórico, fruto de um determinado tempo.
} 
espécie dos últimos burgueses sobre a terra", cujas "maiores dúvidas e confusões"99 residiriam na pergunta sobre o quê daquele mundo deveriam salvar.

A ideia de arte popular, em contrapartida, era a defesa das formulações críticas e satíricas ao mundo burguês. Mas trazia também o desejo de imaginar uma nova forma de atuação artística. A saída exigia a tentativa de entender-se historicamente, enquanto classe, e procurar enfrentar a criação artística a partir de uma relação direta com a realidade. Jacobbi parece sugerir um deslocamento na função do intelectual-artista, uma postura dialética de sair de si em direção ao outro. Novamente a imagem de "ida ao povo" supondo também um movimento interno daquele que se desloca. A ele, que considerava o mundo moderno marcado pelo individualismo, interessava a busca por formas que "resgatassem" um sentido de coletividade, o que implicava uma participação diversa do artista. Significava, em última instância, a preocupação com um desempenho não apenas artístico, mas também extra-artístico, social, político.

Em suma, a ideia de popular para Ruggero Jacobbi ia além de questões de destinação ou modo de produção (financiamento público ou deslocamentos da circulação por teatro periféricos, por exemplo) ou de forma dramatúrgica. Popular ligava-se a uma atitude realista popular que exigia autocrítica quanto à função social da arte. É desse ângulo que, para Ruggero Jacobbi, poderiam ser populares ao mesmo tempo uma tragédia como Leonor de Mendonça e uma farsa de Martins Pena. O importante é que articulassem na forma ou no tema fronteiras antiburguesas.

\footnotetext{
99 JACOBBI, R. Ekateria Ivanovna (1912). Correio do Povo, Porto Alegre, 16.5.1959. In: da razão teatral. São Paulo: Perspectiva, 2005, p. 180.
} 


\section{Realismo popular}

Ruggero, assim como Gyorg Lukács - e tendo este como referência consciente $^{100}$ - defende a ideia de realismo como postura avançada da arte. O realismo verdadeiro para Jacobbi seria universal, interessado na vida como totalidade, no seu sentido histórico. Seriam, portanto, universais e populares, portanto realistas, as obras de Shakespeare, Tolstoi, Goethe, Schiller, Goldoni. No famoso debate sobre o realismo, Lukács considerava que a arte deveria empreender o esforço de representar uma realidade totalizante:

Se a literatura é, de fato, uma forma especial de reflexo da realidade objetiva, ela terá todo o empenho em apreender essa realidade tal como ela é de fato constituída e não se limitar a reproduzir o que e o como da sua aparência imediata. [...] o problema da totalidade objetiva da realidade desempenha um papel decisivo. ${ }^{101}$

Lukács, entretanto, rejeitava o projeto literário formado no Naturalismo europeu justamente por sua suposta ênfase na descrição das vida estragada, seu apego à particularidade ambiental, sem maior conexão com as possibilidades positivas de sua superação. Não é o caso de entrar aqui no debate sobre o Naturalismo, mas no caso do teatro é preciso considerar que os principais esforços no sentido de um drama social

\footnotetext{
100 "Gyorg Lukács reconhece como dom e resultado principal da arte de Tolstoi aquele "caráter de totalidade’ que Hegel exigia da expressão literária, e especialmente da expressão épica. Seria essa medida de síntese instintiva (de que Lukács fornece abundantes e importantes exemplos) que faria de Tolstoi o continuador único do grande realismo da primeira metade do século XIX, justamente na época do baixo realismo e até mesmo da inflação naturalística". (JACCOBBI, R. O Poder das Trevas (1886). Correio do Povo, Literária, Porto Alegre, 11.04.1959. Série: Teatro Universal. In: Crítica da razão teatral. São Paulo: Perspectiva, 2005, p. 169.

${ }_{101}$ LUKÁCS, G. apud BARRENTO, J. (Org.). Realismo, materialismo, utopia. Lisboa: Moraes Editores, 1978, p.40.
} 
moderno surgiram a partir das tentativas artísticas realizadas por autores que mantinham diálogo com um Naturalismo, mesmo que no sentido de superá-lo.

O interesse de Jacobbi por experiências do drama social crítico pode ser vinculado a essa percepção de que a despeito dos limites da forma dramática individualizante, a temática social crítica era capaz de deslocar os hábitos burgueses do teatro.

Sua encenação de Tobacco road, peça de tradição política dos Estados Unidos, primeira montagem dirigida por Ruggero Jacobbi no Brasil, em 1948, com o Teatro Popular de Arte, pode ser considerada exemplo desse interesse por um realismo popular que fosse capaz de superar as aparências naturalistas. ${ }^{102}$

Tobacco road escrita em 1933 por Jack Kirkland e inspirada na novela de Erskine Caldwell trata da miséria do Sul dos Estados Unidos em um momento de grande representatividade do partido comunista lá, sendo "um exemplar típico da arte engajada norte-americana do entre guerras" ${ }^{\text {103 }}$. São personagens que não agem e que não tem, portanto, contornos individualizantes convencionais. A peça trata da situação miserável em que se encontra uma família no sul dos Estados Unidos. Jeeter Lester e sua família são famintos habitantes da Geórgia que moram em uma casa que mal se mantém em pé. A ação da peça, na realidade, condensa em três atos dois dias de vida dos Lester. Depois de perder a pouca terra que possuía, a fonte de renda que lhes resta é a madeira de um velho carvalho que, às vezes, conseguem vender como lenha na cidade. Tobacco road apresenta um panorama histórico do progresso no sul dos estados unidos bastante fiel às etapas de desenvolvimento da base econômica daquela região.

\footnotetext{
102 Tobacco Road estreou no dia 06 de maio de 1948, com direção de Ruggero. No elenco estavam Sadi Cabral, Italia Fausta, Maria Della Costa e Sandro Polloni. Quando a peça veio para o Teatro Municipal em São Paulo, em 1949, Ziembinski participou no elenco.

103 BRANDÃO, T. Uma empresa e seus segredos: companhia Maria Della Costa. São Paulo: Perspectiva, 2005, p. 186.
} 
Por ser a miséria revelada em sua aspereza e crueldade, não é possível ao leitor a identificação ou mesmo "simpatia humana" com aquelas figuras, pois o estrago social já foi completo: neto humilha a avó, pai vende a filha etc. Em Tobacco road, em que pese a modelagem naturalista, a miséria é tomada como "aberração", e essa relativa distância dada pelo excesso da forma permite a quem lê uma percepção de uma pressão externa sobre aquela miséria, a noção do fosso social que separa a realidade das classes. Fica a impressão de que a bondade e a generosidade dependem muito mais das condições econômicas do que a tradição cristã e a própria ideologia burguesa nos fazem crer $^{104}$.

Com Tobacco road são colocados em cena no teatro profissional brasileiro personagens miseráveis, marginalizados, verdadeiros "lumpens", coisa raríssima até então ${ }^{105}$.

Força popular da comédia

Se Ruggero Jacobbi foi capaz de sondar o realismo por dentro do drama naturalista em crise, sua compreensão aberta do sentido de um realismo popular o levou ao estudo de formas consideradas rebaixadas pela tradição erudita, costumeiramente associadas ao teatro comercial de outrora. A farsa, entre outras formas de comédia popular, é desses gêneros mais ou menos decadentes que mereceu sua atenção.

\footnotetext{
${ }^{104}$ O romance de 1932 foi um enorme sucesso e por isso foi dramatizado e levado à Broadway em 1933 que na época levava à cena peças da tradição de esquerda. Foi igualmente um enorme sucesso e um dos espetáculos que mais tempo ficou em cartaz, com mais de três mil apresentações. É possível que o sucesso da peça nos EUA tenha sido motivador da encenação brasileira. Mas é certo também que o interesse de Ruggero pelo texto incide sobre seu caráter social, ainda que não se tenha notícias de que aqui no Brasil o espetáculo tenha sido percebido por sua temática.

${ }^{105}$ A crítica, no entanto, não parece ter se dado conta do forte cunho social encenado, da novidade temática (Essa ideia foi desenvolvida pela professora Maria Silvia Betti em curso ministrado em 2015, Dramaturgia Norte-Americana no Brasil: Perspectivas (1946-1968), pelo programa de Pós-Graduação em Artes Cênicas da USP). O que foi ressaltado com veemência foram os efeitos técnicos, certa "monotonia" na encenação, com ritmos lentos e o fato de Ruggero ter levado ao palco "terra de verdade", "água dentro do barril e legítimos destroços de um velho automóvel" (OSCAR, Henrique Apud BRANDÃO, T. Op. Cit., p.192).
} 
A farsa seria, para ele, numa abordagem incomum, uma lição de materialismo. Por sua estrutura esquemática, de tipos, revelaria mecanismos das relações sociais e econômicas que movem a história contada. Ele enxergava nas farsas, um de seus gêneros populares preferidos, um caminho para a arte antiburguesa já dado pela atitude formal:

O mundo da farsa é um mundo sem sonhos, racional, material, corriqueiro. O indivíduo deixa de existir: é igual a todos os outros, é um animal e nada mais. O que costumamos chamar de personalidade fica reduzida a um nome ou, mais frequentemente, a um cacoete. Por isso, a farsa encontrou sua expressão definitiva no teatro improvisado, na commedia dell'arte, porque chegou à perfeição da máscara, do tipo invariável, resumo de uma categoria de interesses ou de apetites. ${ }^{106}$

Para o autor, a farsa, por sua própria estrutura ostensivamente mecanizada, impedia a psicologização, o "profundismo" que desviava, em tantos casos, a atenção daquilo que é essencial das relações humanas. Era antidramática por natureza. A farsa mostrava o esqueleto do homem, em sua dimensão mais crua, seus desejos condicionados, revelando assim os interesses materiais em jogo, a luta de classes, a dimensão histórica das relações humanas. Daí sua valorização de um autor como Martins Pena:

\footnotetext{
106 JACOBBI, R. Camas gêmeas, cadáveres e vigaristas. Folha da Noite, 6.11 e 7.11.1952. In:
} Crítica da razão teatral. São Paulo: Perspectiva, 2005, p. 25. 
Com as peças de Martins Pena, inicia-se um gênero ainda hoje continuado por autores maiores e menores, uma investigação, entre bonachona e maliciosa, da realidade urbana brasileira. ${ }^{107}$

Como modelo clássico de popular, Ruggero encenou ainda no Brasil Carlo Goldoni e a commedia dell'arte, sugerindo seu interesse modelar para os palcos nacionais $^{108}$. Sua primeira montagem foi Arlequim servidor de dois amos, que Ruggero dirigiu em 1949, ainda no Rio de Janeiro, com o Teatro dos Doze. Esse período é lembrado por Ruggero como a mais linda experiência de sua vida. O grupo havia acabado de ser formado com integrantes do Teatro do Estudante do Brasil (TEB), de Paschoal Carlos Magno. Participavam do grupo Sérgio Cardoso, Sérgio Britto, Ary Palmeira, entre outros.

Na Itália, o Piccolo Teatro de Milano encenou a mesma peça em 1947, com direção de Strehler, que Ruggero não chegou a assistir.

Pela precariedade financeira em que o grupo Teatro dos Doze se encontrava Ruggero Jacobbi foi diretor, figurinista e cenógrafo da peça. $\mathrm{Na}$ encenação, ele procurou paralelos com traços de brasilidade, identificou tipos populares italianos com tipos brasileiros, como descreveu no seguinte trecho de seu livro Le rondini di Spoleto, em 1977, identificado e transcrito por Berenice Raulino:

No meu Arlequim de '48, a maior dificuldade foi a de convencer o esplêndido Sérgio Cardoso a deixar um pouco de lado as suas preocupações de elegância e a não fechar a porta aos espiritozinhos

\footnotetext{
${ }^{107}$ JACOBBI, R. O teatro de Machado de Assis, Correio do Povo, Porto Alegre, 11.10.1958. In: Op. Cit., p. 164.

${ }_{108}$ Aliás, Ruggero nasceu e viveu os primeiros anos de sua vida em Veneza, cidade berço da Commedia dell'arte.
} 
nacionais do moleque negro, do Saci-Pererê, do dançarino grotesco índio, do carioca carnavalesco. O resultado foi também estupor. ${ }^{109}$

Essa explícita preocupação em traduzir os tipos populares para um contexto tradicional brasileiro é um exemplo da atitude artística de Ruggero. E é um exemplo de seu desejo de que a commedia dell'arte servisse como um modelo para uma dramaturgia e um tipo de atuação marcados por improvisações e que, sem preconceitos, aprendessem com a tradição popular brasileira.

Em 1949, no primeiro volume da Revista Dionysos, Ruggero apresentou um estudo sobre Goldoni e a Commedia dell'arte, em que introduzia ao leitor e espectador brasileiros a história daquele teatro popular, inédito no país, sua função política de crítica imediata - como as revistas políticas - os tipos das máscaras, a força da improvisação e também a função e importância de Goldoni na transição para a modernidade. Goldoni seria o primeiro realista moderno.

Num recuo histórico, Ruggero identificou as características presentes na comédia romana de Plauto que seriam exatamente as mesmas a serem encontradas na Commedia, "no teatro dos fabulosos Arlequins dos séculos XVI, XVII e XVIII", destacando a dialética particularização-generalização:

No tratamento das máscaras, há uma perpétua oscilação entre a tendência a fixar tipos universais e o gosto da atualidade histórica e social. $^{110}$

\footnotetext{
${ }^{109}$ JACOBBI, R. Apud RAULINO, B. Ruggero Jacobbi. São Paulo: Perspectiva, 2002, p. 76.

${ }^{110}$ JACOBBI, R. Goldoni e a commedia dell'arte. Revista Dionysos. Rio de Janeiro, $\mathrm{n}^{\circ}$ 1, 1.1.1949. In: Crítica da razão teatral. São Paulo: Perspectiva, 2005, p. 75.
} 
Nesse mesmo texto traça uma perspectiva histórica dos caminhos do teatro popular, seus intercâmbios com o teatro literário. Nos enredos populares da Commedia encontram-se elementos clássicos adaptados pelo teatro de corte, mas já abertos à incorporação da temática atual (é o que permite o surgimento de personagens como soldados espanhóis e franceses que haviam invadido a Itália). Mas para além da forma, o popular se define por uma atitude de abertura ao tempo:

[...] Mas não é a temática, não são os enredos que importam para um teatro que só os aproveita como pretextos para a fertilidade criadora do ator. A commedia dell'arte é isso: comédia da arte de representar. Nada mais. E diante do teatro das Cortes em que o único progresso foi aquele da cenografia, realizada, aliás, por talentosos homens do povo com o dinheiro dos príncipes, ergue-se o teatro popular em toda a sua vitalidade. $^{111}$

Já no século XVIII, após mais de duzentos anos de desenvolvimento, a própria tradição popular da commedia dell 'arte perdia seu sentido original. Ao ficar novamente absorvida pelo mundo da corte, vivia como um simulacro do passado. Foi nesse momento de decadência que entrou em cena Carlo Goldoni, com espírito renovador e procurando integrar a tradição popular à literária. Por meios literários, Goldoni promoveu uma retomada do espírito popular de sátira da commedia dell'arte. Sem renegar as "qualidades teatrais" converteu alguns dos velhos improvisos em obras primas da comédia de seu tempo.

${ }^{111}$ Id. Ibid., p. 77. 
Os objetivos declarados da reforma goldoniana foram, antes de tudo, a observação da realidade psicológica e social; em segundo lugar, a necessidade, para o teatro, de readquirir um conteúdo ético, recobrando sua posição de intérprete e, ao mesmo tempo, educador da opinião pública. ${ }^{112}$

O gesto de Goldoni seria, assim, o mesmo do teatro moderno: o da busca, por meio da força integradora da teatralidade, de uma relação histórica com seu tempo.

Gramsci foi um grande apreciador de Goldoni. Considerava-o um dos únicos grandes autores do pós-renascimento italiano, pois apresentava uma mentalidade crítica que superava seu tempo histórico:

Por que Goldoni é popular ainda hoje? Goldoni é quase "único" na tradição literária italiana. Suas atitudes ideológicas: democrata antes de ter lido Rousseau e antes da Revolução Francesa. Conteúdo popular de suas comédias: língua popular no que toca à expressão, crítica mordaz da aristocracia corrompida e apodrecida. ${ }^{113}$

A segunda peça de Goldoni feita por Jacobbi foi $O$ Mentiroso ${ }^{114}$, encenada em São Paulo, no TBC, em 1949. Ruggero Jacobbi além de fazer a tradução do italiano, redigiu uma versão da peça com cortes de texto, adaptação de linguagem e até inclusão de termos e piadas. No programa do espetáculo, Jacobbi fez uma apresentação das principais máscaras da commedia dell'arte e no dia da estreia realizou uma palestra em que apresentava a forma e a obra de Goldoni. A insistência com que procurou situar

\footnotetext{
${ }^{112}$ Id. Ibid., p. 81.

${ }^{113}$ GRAMSCI, A. Literatura e vida nacional. Rio de Janeiro: Editora Civilização brasileira, 1968, p. 78

${ }^{114}$ Ainda viria a encenar Mirandolina, em 1955, com o Teatro Popular de Arte, de Maria Della Costa. A tradução quem fez foi Itália Fausta e a cenografia Gianni Ratto. No elenco: Maria Della Costa, Sérgio Britto e Fernanda Montenegro, entre outros. Estreou no Teatro Maria Della Costa em julho de 1955.
} 
aquele trabalho e sua situação histórica indica as intenções programáticas de Ruggero quanto ao que estava em jogo: uma nova etapa do teatro brasileiro ganharia muito, também politicamente, com a pesquisa desses padrões “clássicos" de uma estética realista popular.

O modelo popular de Brecht

O leque de interesse dramatúrgicos de Ruggero Jacobbi, aqui mencionados para uma melhor compreensão de sua visão sobre um possível projeto nacional popular, teria que esbarrar, em algum ponto, com a obra de Brecht. As preocupações comuns são muitas. O espetáculo A ronda dos malandros dirigido por Ruggero no TBC em 1950 foi a primeira tentativa de adaptação de Brecht no Brasil. Duas semanas após a estreia teve sua temporada cancelada pelo próprio Franco Zampari. Ruggero apresentou uma peça de teor explicitamente político e num formato completamente diverso de qualquer coisa já mostrada no TBC. Durante algum tempo houve uma polêmica se a censura havia ocorrido por motivos políticos ou estéticos. Ao que parece foi a relação imbricada entre estética e política que motivou a controvérsia em torno da montagem.

Para Jacobbi, a obra de Brecht seria:

[...] uma das mais violentas demonstrações da unidade fundamental de conteúdo e forma no fenômeno da expressão e, em particular, da expressão dramática ${ }^{115}$

115 JACOBBI, R. Aspectos de Brecht. IN: Crítica da razão teatral. São Paulo: Perspectiva, 2005, p. 191 
Brecht trazia assim um exemplo radical de conjugação de modelagem clássica com o interesse popular, trabalho fundado numa crítica materialista da modernidade, com uma linguagem clara e reconhecível. O dramaturgo alemão recuperava, a partir da amálgama de elementos populares de diversas culturas, de ritmos e sentido "francamente populares", temas fundamentais do teatro tradicional, causando um choque na recepção:

A verdade é que Brecht procura a expressão adequada para um conteúdo toto cœelo alheio à temática do teatro tradicional. Isto choca e ofende os nossos hábitos, porém obriga-nos a abrir os olhos sobre um estado de coisas que não é apenas artístico e que exige a nossa atenção, a nossa participação ${ }^{116}$.

A primeira ideia de Ruggero em A ronda dos malandros era levar ao palco o texto de Brecht A ópera de três vinténs (Dreigroschenoper) que tanto circulara pelos intelectuais italianos durante os anos de fascismo ${ }^{117}$. Mas Ruggero sabia dos riscos de censura e optou pela adaptação da versão original - menos polêmica - a Ópera do mendigo (The Beggar's Opera), escrita por John Gay em 1729. Brecht, em 1928, também havia tomado como modelo o texto de Gay para a elaboração de A ópera de três vinténs. E seu intuito, como o de Ruggero, não era apenas temático, mas o de questionar o próprio vínculo do artista com o aparelho cultural:

\footnotetext{
${ }_{117}^{116}$ Id. Ibid., p. 191.

${ }^{117}$ Ópera de três vinténs foi levada aos palcos italianos já em 1930, por Giulio Bragaglia, e em 1943 por Vito Pandolfi, contemporâneo de Ruggero Jacobbi. A encenação de Pandolfi, segundo a pesquisadora Berenice Raulino, "passa para a história como um ato contra o fascismo na Itália". Vito Pandolfi é inclusive preso pela polícia de Mussolini por causa dessa montagem. É provável que Ruggero houvesse assistido ao espetáculo. (RAULINO, B. Ruggero Jacobbi. São Paulo: Perspectiva, 2002, p. 116.)
} 
A Dreigroschenoper (Ópera de três vinténs) entrou com força no território do teatro de diversão, fixando ao mesmo tempo os novos limites do espetáculo $\operatorname{popular}^{118}$.

Ruggero, testando à sua maneira os limites da estrutura, fez diversas modificações no argumento de Gay, com inserções de situações, espaços e personagens advindos da peça de Brecht. Em sua montagem usou cartazes que ironizavam e comentavam situações da trama e incluiu um epílogo, em que Sérgio Cardoso recitava um poema inteiro de Cruz e Souza, Litania dos pobres, com atores avançando em coro, usando "máscaras grotescas", com rostos cobertos de "feridas e chagas". A luz do palco era apagada depois da última cena e quando a acendiam novamente o palco estava tomado por uma cor "sinistra, esverdeada: uma luz de aquário ou de túmulo"119. Os pobres levantavam os braços com os punhos cerrados, em clara referência ao histórico gesto comunista $^{120}$.

Quando, cinco anos mais tarde, Ruggero entrevistou Brecht - ambos assistiam ao ensaio da montagem de Strehler A ópera de três vinténs para o Piccolo Teatro de Milano - este lhe disse que não estava contente com a presente montagem do italiano, pois acreditava que só havia sentido uma remontagem de sua peça se ela fosse transformada pelos problemas e circunstâncias atuais:

\footnotetext{
${ }_{118}^{11}$ JACOBBI, R. Aspectos de Brecht. In: Op. Cit., p. 190.

${ }^{119}$ As citações referem-se a rubricas da versão do texto $A$ ronda dos malandros traduzida e adaptada por Carla Civelli e Maurício Barroso e usada por Jacobbi na montagem do TBC. O documento foi localizado no Arquivo Miroel Silveira e é referente às cópias usadas pelos censores para emissão de parecer para o Departamento Estadual de Imprensa e Propaganda (DEIC) de São Paulo.

${ }^{120}$ Ruggero Jacobbi ao falar sobre a censura do poema de Cruz e Souza pelo DEIP (Departamento Estadual de Imprensa e Propaganda) de São Paulo diz que não censuraram o texto, porque era um "clássico da poesia brasileira", mas "censuraram a maneira gestual com a qual era apresentado. Havia gestos de revolta (levanta o punho cerrado) que acompanhavam o poema". (Depoimento de Ruggero Jacobbi In: LERNER, Julio. A Aventura do Teatro Paulista. [Filme-vídeo]. Produção e entrevistas de Júlio Lerner. São Paulo, série de televisão produzida pela TV Cultura, 1981. VHS)
} 
Considero a Dreigroschenoper, assim como está, superada. Ela permanece ligada a época em que foi escrita. O que resiste nessa peça é a ideia de John Gay, que é imortal, porém no seguinte sentido: cada época, cada nação, cada teatro pode retomar esse "canevas" e transformá-lo segundo os problemas e as circunstâncias atuais. ${ }^{121}$

O depoimento diz mais sobre Ruggero do que sobre Brecht. A atualidade brasileira dissolvia-se na colagem de textos, pantomimas, cartazes e gestos que se opunham às expectativas do público habitual do TBC. Após duas semanas de apresentação, Franco Zampari retirou a peça de cartaz, aparentemente sem nenhum aviso prévio ou diálogo. Franco Zampari alegou motivo econômico, mas a casa esteve cheia durante todas as apresentações ${ }^{122}$. O resultado foi o pedido de demissão de Ruggero Jacobbi do corpo de diretores do $\mathrm{TBC}^{123}$. Depois disso Brecht só seria

${ }^{121}$ BRECHT, B. Apud JACOBBI, R. Revista Teatro Brasileiro, Rio de Janeiro, n.7, maio/junho 1956. In: Crítica da razão teatral. São Paulo: Perspectiva, 2005, p. 218.

${ }_{122}$ GUZIK, A. TBC: crônica de um sonho. São Paulo: Perspectiva, 1986.

${ }^{123}$ Segundo o próprio depoimento de Ruggero: "a Ronda dos Malandros nasceu da ideia muito ingênua de minha parte de encenar a Dreigroschenoper de Brecht, com as músicas de Kurt Weill. Isso é o que eu queria fazer. Vendo que a censura nunca teria aceito essa obra, fizemos com Mauricio Barroso e outros colaboradores uma adaptação da peça originária inglesa do século XVIII, a Beggar's Opera de John Gay. Aliás, é o que o próprio Brecht havia feito no seu tempo e na Alemanha. Eu não quis dar à peça uma época determinada. Havia roupas, cabeleiras e tudo mais de épocas diferentes, século XVII, começo do século XIX, alguma coisa absolutamente contemporânea, tudo misturado. E na música, utilizei em grande parte Jazz americano. Era um espetáculo absolutamente fora do comum e fora das regras para a época, que era uma época de respeito absoluto pelos textos escritos. Esse texto que não se sabia se era do autor ou era do encenador ou era de uma equipe, era uma coisa na época inconcebível. E todo mundo veio assistir um pouco com ar de suspeita. A peça teve alguma dificuldade com a censura, houve alguns cortes e já na estreia sentia um certo nervosismo. Inclusive porque alguns souberam pelo Guilherme de Almeida, que era um conselheiro literário do TBC, souberam que eu terminava essa peça inglesa do século XVIII com um poema do Cruz e Souza, A litania dos pobres, o que parecia a maior loucura do ponto de vista literário, estilístico. Apesar disso, o espetáculo tinha força. [...] Sem dúvida deve ter havido alguma coisa. Entre os sócios, entre os fundadores do TBC. $\mathrm{O}$ assunto foi reduzido pelo Zampari a uma questão puramente econômica: 'Esta peça não vai, o desequilíbrio entre a despesa e a receita vai ser imenso, Não podemos correr esse risco'. Esta peça faz duas semanas e depois desaparece do cartaz. Eu não achei justo, achei que era preciso ver dia a dia as variações do público e que essa decisão tinha que ser adiada. Quer dizer, eu não queria que se dissesse que o meu filho era tuberculoso antes de mandar vir o médico. Tinha que vir o médico e verificar se era tuberculoso ou não. Eu defendi esse meu filho, essa minha criatura um pouco trôpega, um pouco imatura e fui-me embora. Fui-me embora e começaram outras aventuras, inclusive a do cinema, que depois me trouxe de volta ao TBC, pelos caminhos de São Bernardo, da Vera Cruz. (Depoimento de Ruggero Jacobbi para o documentário Aventura do Teatro Paulista 5 e 6 . Série de televisão produzida pela TV Cultura de São Paulo, em 1981. Produção e entrevistas de Júlio Lerner). 
encenado no teatro profissional brasileiro por Maria Della Costa, em 1958, com A alma boa de Setsuan ${ }^{124}$.

\section{Produção e circulação popular}

A ideia de um teatro popular, para Jacobbi, passava, também, pelo fomento a um novo sistema de produção e circulação do teatro, ainda que em circunstância completamente diversas daquelas conhecidas por ele no pós-guerra.

Em sua busca por uma renovação real, "sem aspas" maquiadoras, Ruggero Jacobbi defendeu e incentivou a existência de subsídios estatais para produções culturais interessadas num projeto coletivo maior, de sentido público. Em 1951 participou, como vice-presidente, junto com Madalena Nicol da criação de um teatro que deveria ser, em parte, subvencionado pelo município, a Sociedade Paulista de Teatro. Para conseguirem um projeto de lei que permitisse o financiamento municipal, a Sociedade fez um processo em que anexou o estatuto do grupo, registrado em cartório, com todas as notícias de jornal sobre as apresentações que haviam feito ${ }^{125}$. Na imprensa apareciam divulgados os propósitos da Sociedade: "proporcionar espetáculos teatrais a preços populares, a fim de incutir o gosto pelo bom teatro em nossa população" ${ }^{126}$. Os itens do estatuto - anexados no processo - sugerem semelhanças com os preceitos do Piccolo e do TNP, de Jean Vilar. A atividade da Sociedade Paulista de Teatro teria em

\footnotetext{
${ }^{124}$ Em 1951 Alfredo Mesquita dirigiu, na Escola de Arte Dramática (EAD), A Exceção e a Regra, de Bertolt Brecht. A tradução do texto foi feita pelo próprio Alfredo Mesquita. No elenco estavam, por exemplo, José Renato e Xandó Batista.

${ }^{125}$ Quem assinou como presidente da Sociedade foi o Professor Canuto Mendes de Almeida, Ruggero aparece como Vice-presidente. Tesoureiro: Dr. Vicente Catalano; Tesoureiro: Vera Nunes; $1^{\circ}$ secretário: Julio Gouveia (que criará junto com sua esposa Tatiana Belinky o Teatro-Escola de São Paulo (TESP), que funcionou entre os anos de 1949 e 1951); $2^{a}$ secretária: Madalena Nicol.

${ }_{126}$ ESTREIAM Novos Artistas "Arlequim, servidor de dois amos", no Municipal. O Dia. São Paulo, 18.8.1951.
} 
vista fundamentalmente a popularização e a descentralização do teatro feitas com base num repertório moderno e clássico (não comercial). Pretendiam, assim:

\begin{abstract}
A) oferecer aos elementos novos e promissores do teatro paulista a possibilidade de trabalhar e de se aperfeiçoar sob direção competente, em espetáculos de cunho educativo e cultural, fora de qualquer comercialismo. B) Atrair para o teatro grandes massas populares, inclusive os moradores de bairros afastados, as coletividades estudantis, juvenis, e infantis de todas as classes sociais, e todos os que, por motivos econômicos ou falta de tradições não tem ainda o hábito ou amor ao teatro ${ }^{127}$.
\end{abstract}

No estatuto ainda se divulgam os planos para a realização do programa, a partir da criação de companhias teatrais coligadas, que se combinariam para a execução dos objetivos totais. Assim:

A) Companhia de Teatro Clássico, para encenar as obras imortais da literatura dramática, além de espetáculos especiais de conteúdo histórico ou patriótico. B) Companhia de Teatro Cômico, para levar aos bairros populares peças divertidas e fáceis, que encaminhem através do humorismo e da sátira o público ao teatro, como diversão sadia e necessária. C) Companhia de Teatro Infantil para criar nas novas gerações o amor pelo teatro e para contribuir através do teatro, à educação moral e intelectual da juventude. D) Teatro Experimental de S. Paulo para revelar e lançar os novos autores brasileiros, sempre à

\footnotetext{
${ }^{127}$ ESTATUTOS da Sociedade Paulista de Teatro (S.P.T.), 3 de julho de 1951, 4. Registro de Títulos e Documentos da Comarca da Capital do Estado de São Paulo, República dos Estados Unidos do Brasil, 20 nov. 1951. (Ver Anexo).
} 
procura de una oportunidade no teatro comercial, mormente quando se dedicam as formas de literatura teatral mais modernas e ousadas. ${ }^{128}$

A peça de estreia da Sociedade foi Arlequim servidor de dois amos, dia 16 de agosto de 1951, com direção de Ruggero Jacobbi, no Teatro Municipal com preço popular a 15 cruzeiros $^{129}$.

Na Folha da Tarde, Miroel Silveira comemorou a estreia, saudada por toda intelectualidade progressista. ${ }^{130}$ Outras sessões se seguiram em teatros com o São Paulo, o Colombo e o Brás-Politeama. E renderam boas críticas, em quase todos os jornais tradicionais, também nos veículos comunistas.

No fim do ano, com o projeto de lei número 595, outorgado em novembro de 1951, conseguiram a subvenção estatal de 200.000 mil cruzeiros. No entanto, o grupo não conseguiu ir para frente. Em meados de 1952 o elenco original estava dissolvido. Ruggero Jacobbi considerava que não havia ali uma "orientação muito firme" ${ }^{\text {"131. De }}$ qualquer maneira marcou uma tentativa de popularização de um teatro de arte numa perspectiva formativa.

Outra marca de militância foi sua defesa pela subvenção do Teatro Experimental do Negro. No jornal Folha da Noite, em 1953, Jacobbi fez um apelo ao prefeito Jânio Quadros, recentemente empossado, referindo-se às condições da companhia fundada e

\footnotetext{
${ }^{128}$ ESTATUTOS da Sociedade Paulista de Teatro (S.P.T.), 3 de julho de 1951, 4. Registro de Títulos e Documentos da Comarca da Capital do Estado de São Paulo, República dos Estados Unidos do Brasil, 20 nov. 1951. (Ver Anexo).

129 No elenco estavam, por exemplo, Madalena Nicol, Vera Nunes, Jaime Barcelos, Sergio Brito e Jackson de Sousa.

${ }^{130}$ Em sua crítica Miroel diz que o teatro grego era tão expressivo porque reunia no mesmo anfiteatro "os chefes de governo", "ricos negociantes", com "guerreiros", como "os pobres" e até mesmo "os escravos": "O que se representava diante deles tinha que ser forçosamente uma síntese de temperamentos, capacidades e interesses diversos". Na sociedade atual, continua Miroel, "por forças das circunstâncias econômicas", o teatro estava relegado às elites, divorciado das "elites de inteligência e das "massas aculturadas mas tremendamente sensível, ávida de emoção e de algo que a redima do abismo de rotina e de feiura a que a relegaram" SILVEIRA, M. Arlequim de Ruggero. Radar, 24 a 30.08.1951. In: . A outra Crítica. São Paulo: Ed. Símbolo, 1976, p. 48.

${ }^{131}$ JACOBBI, R. Dinheiro é dinheiro, Última Hora, 24.03.1952. In: , Crítica da razão teatral. São Paulo: Perspectiva, 2005, p. 8.
} 
dirigida por Abdias do Nascimento no Rio de Janeiro e que agora se encontrava em São Paulo. Para além da urgência do caso, o texto fazia pressão para a criação de uma política cultural para a cidade, falava na necessidade de municipalização de teatros que deveriam ser financiados pelo Estado, pedia subvenção de companhias de teatro infantil etc.:

Cabe ao senhor Jânio Quadros tomar conhecimento dos problemas teatrais de São Paulo, com vistas menos às soluções grandiosas e impossíveis e mais a elaboração de uma rotina modesta e honesta, com a qual os grupos de arte dramática possam contar de antemão, sem sonhar demais, mas também sem surpresas desagradáveis ${ }^{132}$.

Jacobbi participou de várias iniciativas de descentralização. Era, para ele, uma ação necessária, inclusive como saída da crise financeira em que o teatro se encontrava. Mas sua opinião não era a corrente. Em 1952, ano de uma forte crise no teatro em São Paulo, a Prefeitura encampou um projeto de criação de teatros na periferia. Fundou o teatro Arthur Azevedo, na Mooca. Reformou o Colombo, no Braz e o São Paulo, na Glória. Um dos motivos para a crise eram os altos preços que as companhias tinham de pagar pelos teatros e a ausência de público pagante - diversas companhias, amadoras e profissionais, encerraram suas atividades. A ação da prefeitura viria a socorrer as companhias, construindo teatros públicos, que não exigiriam pagamento dos artistas. No entanto, a reação de muitos - ao contrário de Jacobbi - foi de indignação com o fato desse empreendimento ter sido realizado em bairros populares, onde não havia público habituado. A Cia. Armando Couto - cujo diretor, Armando Couto, já tinha participado

\footnotetext{
132 JACOBBI, R. Apelo ao senhor Jânio Quadros. Folha da Noite, São Paulo 31.3.1953. In: Op. Cit., p. 52.
} 
de iniciativas como a da Sociedade Paulista de Teatro, por exemplo, preferiu pagar caro pelo aluguel do Teatro Cultura Artística, do que ficar no teatro na Mooca, de graça ${ }^{133}$.

Na revista Dionysos, edição que trata da história do TBC, há um trecho de um artigo publicado pela revista ANHEMBI em que a questão da construção desses "teatros populares" aparece:

Enquanto isso a Prefeitura Municipal insiste na execução do plano absurdo de construção de "teatros de periferia", teatros tão afastados dos centros de população que ninguém os procura a ponto de ter o $\mathrm{Sr}$. Armando Couto preferido trabalhar no Cultura Artística pagando aluguel a ficar no "Arthur Azevedo" de graça ${ }^{134}$

Ciente de que os ventos não sopravam a favor da subvenção estatal, Ruggero aceitava a possibilidade de manutenção de teatros por capitalistas esclarecidos. O ponto sempre evidente nesses casos era que a liberdade criativa e a experimentação do artista não poderiam viver apenas de bilheteria, sendo preciso a subvenção de algum tipo quando esses aspectos se radicalizam.

A ideia de Jacobbi sobre descentralização e municipalização dos teatros, como meio de democratização do acesso, dialoga com os preceitos organizadores dos teatros Piccolo na Itália e TNP na França. Mas essas companhias públicas profissionais só fazem sentido diante de um movimento amador consistente.

Para Ruggero Jacobbi, o teatro amador era a fração mais capaz de impulsionar essa transformação conjunta do teatro, de ordem ideológica e produtiva. Justamente por

\footnotetext{
${ }^{133}$ GARCIA, C. Os caminhos do teatro paulista: um panorama registrado em críticas: O Cruzeiro (19511958), A Nação (1963-1964). São Paulo: Prêmio, 2006, p. 112.

${ }^{134}$ ANHEMBI, n 26 , volume IX, jan. 1953.
} 
não terem as amarras e pressões típicas do teatro profissional e do mercado, seriam capaz de uma postura verdadeiramente experimental e empenhada num novo programa.

Jacobbi foi um grande incentivador da constituição de grupos amadores que pudessem experimentar novas dramaturgias, formas de pesquisa sem a pressão da bilheteria.

A história do Teatro Paulista do Estudante deve ser lida, assim, como uma ação importante e mesmo decisiva dentro do conjunto do trabalho de Ruggero Jacobbi no Brasil. O TPE é, por um lado, um ponto de convergência de muitas reflexões teóricas e práticas sobre nacional popular operadas por um grande artista e intelectual. Alguém que já militava em relação a um determinando conjunto de questões estético-políticas, como, por exemplo: no interesse pela matéria específica do país; na escolha de repertório com temas ligados aos explorados; na proposição de formas populares de fundamento antiburguês consideradas "rebaixadas"; no trabalho por condições de produção e de circulação que fomentasse um teatro democrático e verdadeiramente popular para além dos centros produtores de cultura; no empenho, enfim, por construir um sistema para o teatro brasileiro moderno que fosse nacional popular. Por outro lado, a aproximação com o movimento amador politizado que gerou o Teatro Paulista do Estudante traria também uma questão nova: o que significariam essas coordenadas diante do interesse de jovens militantes do Partido Comunista que, num momento político novo do país, decidem se dedicar ao teatro? 
PARTE II

MODERNIZAÇÃO, ENGAJAMENTO E IMPASSES NA TRAJETÓRIA DO TEATRO PAULISTA DO ESTUDANTE 


\section{Capítulo 3}

\section{O IMAGINÁRIO COMUNISTA NA CRIAÇÃO DO TEATRO PAULISTA DO ESTUDANTE}

A história do Teatro Paulista do Estudante não pode ser considerada uma ação individual de Ruggero Jacobbi, ainda que sua orientação seja decisiva. A existência do grupo representou um encontro de gerações e de propósitos estéticos-políticos que dialogavam com interesses e perspectivas ao mesmo tempo comuns e diversas.

Em 1952, Ruggero Jacobbi dirigia o Centro de Estudos Cinematográficos, fundado um ano antes e subvencionado pela Prefeitura de São Paulo. O presidente de honra do núcleo era o cineasta Alberto Cavalcanti. Foi ali que Jacobbi criou seu Curso de Arte Dramática e convidou José Renato e Antunes Filho para lecionarem junto com ele $^{135}$.

A primeira tentativa de se colocar em prática um agrupamento chamado Teatro Paulista do Estudante nasceu naquele Centro, a partir de sugestão feita anteriormente por Paschoal Carlos Magno a Ruggero Jacobbi, no sentido de se aproximar do movimento amador. Um grupo de jovens se organizaria em função das atividades da escola e organizaria um repertório nacional clássico, algo que se pensava como um primeiro passo de um projetado "Instituto Histórico do Teatro Brasileiro"136. Ruggero Jacobbi decide começar os trabalhos do coletivo com três peças nacionais, dirigidas por ele e seus colegas convidados José Renato (ex-aluno da EAD) e Antunes Filho ("o insubstituível colaborador dos diretores do TBC"). Eram elas: As Doutoras, de França

\footnotetext{
135 “Tenho o meu curso de arte dramática que, agora, ficará entregue por algum tempo um antigo aluno meu (e, ainda mais, aluno de Alfredo Mesquita): o culto, talentoso e paciente José Renato, autor, diretor e intérprete que tem diante de si um futuro brilhantíssimo no teatro nacional" (JACOBBI, Ruggero. Qualis Artifex. Folha da Noite, São Paulo, 30.06.1952. In: Crítica da razão teatral. São Paulo: Perspectiva, 2005, p. 56)

${ }^{136}$ Id. Ibid., p. 57.
} 
Júnior, dirigida por Jacobbi; O Diletante, de Martins Pena, dirigido por José Renato - e Quando a Noite Volta, de Samuel Rawet, dirigido por Antunes Filho ${ }^{137}$.

Esse primeiro Teatro Paulista do Estudante surgia com um trabalho sobre peças brasileiras, como um empreendimento cultural experimental, interessado no diálogo com uma tradição que não deveria se limitar a apresentações de espetáculos:

O TPE tem no seu programa uma apresentação prática da história do teatro brasileiro, de Antonio José a Coelho Neto, através de espetáculos, conferências e publicações que poderão vir a ser os elementos básicos de um futuro e indispensável Instituto Histórico do Teatro Brasileiro ${ }^{138}$

O TPE em sua primeira versão, porém, dura pouco. O Centro de Estudos Cinematográficos fecha as portas quando a Prefeitura descumpre o contrato assinado com o Centro, que garantia a subvenção de vinte mil cruzeiros mensais ${ }^{139}$. Fechado o Centro e os cursos ministrados ali, inclusive os trabalhos de teatro, este Teatro Paulista do Estudante se encerra no final de 1952. O ressurgimento do projeto do TPE dependerá de uma nova situação e de novos colaboradores.

O interesse de militantes do PCB por teatro

Em 1954, Gianfrancesco Guarnieri, Vera Gertel e Oduvaldo Vianna Filho, três jovens filhos de militantes célebres do Partido Comunista, de famílias conhecidas por sua militância política e interesses culturais e artísticos, começam a discutir a

\footnotetext{
${ }^{137}$ Id. Ibid., p. 57.

${ }^{138}$ Id. Ibid., p. 57.

${ }^{139}$ Id. Ibid., p. 58.
} 
possibilidade de organizar um trabalho teatral ligado às ações do Partido. Os três integravam a mesma célula do PCB, fazendo parte do comitê cultural. Guarnieri e Vianinha, entre outras funções, tinham naquele momento a tarefa de organizar uma agenda cultural para os estudantes ${ }^{140}$ e foram encarregados pelo Partido de obter ingressos de teatro para os alunos que iriam participar do Festival Internacional da Juventude, um evento político-cultural organizado pelo Partido ${ }^{141}$. Era um momento de grande mobilização cultural na cidade em torno das comemorações do quarto centenário de fundação de São Paulo. Foi naquele ano que Guarnieri conheceu Sandro Polloni que o convidou para assistir a uma sessão de $O$ canto da cotovia, de Anouilh, dirigido por Gianni Ratto e estrelado por Maria Della Costa no Teatro Popular de Arte. A ida a um teatro de qualidade e o encantamento diante da história encenada de Joana D’Arc foram importantes para despertar seu interesse pela atividade cultural como meio de politização. De acordo com Guarnieri:

$$
\begin{aligned}
& \text { Chegamos à conclusão que o movimento cultural e que } \\
& \text { principalmente o meio artístico seriam um meio eficaz de organização, } \\
& \text { onde se poderia discutir, reforçar os grêmios, de estruturar diretórios e } \\
& \text { procurar criar um debate cultural no meio estudantil }{ }^{142} \text {. }
\end{aligned}
$$

Naquele momento, Jacobbi seguia vinculado ao Teatro Popular de Arte, companhia que voltaria a dirigir no mesmo ano. O interesse dos jovens militantes de esquerda pelo trabalho do Teatro Popular de Arte sinalizava, assim, não apenas a

\footnotetext{
${ }^{140}$ GUARNIERI, G Apud KHOURY, S. Atrás da máscara. Rio de Janeiro: Civilização Brasileira, 1984. Volume 1. P. 23.

${ }^{141}$ O Festival, de acordo com Guarnieri, não ocorreu por proibição do governo de Café Filho. (Id. Ibid., p. 23)

${ }^{142}$ Id. Ibid., p. 23.
} 
admiração pela qualidade do coletivo mobilizado em torno de Maria Della Costa, mas uma sintonia com seu projeto artístico que divergia dos padrões do TBC.

Segundo Guarnieri, o Partido Comunista discutia intensamente naquele momento meios de influir no movimento estudantil, de fomentar a participação secundarista e universitária. Posteriormente, ele fez uma dura autocrítica quanto à organização interna do Partido Comunista, avaliando que, no período em que entrou para a Juventude Comunista, quando o Partido ainda estava na clandestinidade, as decisões eram pautadas de cima, não havia diálogo com a realidade específica da vida estudantil e nenhuma abertura para que os jovens ocupassem espaços de debate ${ }^{143}$.

$O$ canto da cotovia surgia aos membros do comitê cultural como um modelo para um trabalho capaz de, no mínimo, quando associado a atividades politizantes, estimular uma vida "espiritualmente mais elevada", dando exemplo de uma "existência mais positiva", o que expandiria o sentido da militância:

A gente estava se preparando para ocupar posições políticas, em vários setores, e a gente intuia que estava faltando uma consciência cultural, dentro do posicionamento político. ${ }^{144}$

Guarnieri conhecia Ruggero Jacobbi há alguns anos. Ruggero era amigo de seu pai, o maestro Edoardo Guarnieri e frequentava sua casa. Ainda naquele ano de 1954, Ruggero Jacobbi ministra uma série de cursos dentro da programação do IV Centenário da cidade de São Paulo. Segundo Berenice Raulino, Guarnieri e Vianinha participaram dessas atividades $^{145}$.

\footnotetext{
${ }^{143}$ ROVERI, S. Gianfrancesco Guarnieri. Um grito solto no ar. São Paulo: Imprensa Oficial, 2004, p. 36. ${ }^{144}$ Trecho de entrevista inédita de Guarnieri concedida a Alessandra Vannucci em junho de 1997.

${ }^{145}$ RAULINO, B. Ruggero Jacobbi. São Paulo: Perspectiva, 2002, p. 159. A informação é questionada por Flávio Migliaccio (mais tarde integrante do TPE) que esteve presente a um dos cursos.
} 
De qualquer modo foi um vínculo também pessoal, estreitado pelo interesse renovado dos jovens pelo teatro, que contribuiu para aproximação do italiano às atividades partidárias. Convidado por alguém do partido (Guarnieri não se lembra quem foi), Ruggero Jacobbi participa de algumas reuniões do comitê para debater a função da cultura na formação dos jovens. Assim, com sua orientação, se confirma a ideia da criação de um grupo de teatro ${ }^{146}$. Também por sua influência escolhem o nome Teatro Paulista do Estudante, agora associado diretamente à Juventude Comunista.

O TPE foi fruto, portanto, da conjugação de várias linhas de força. De um lado, a orientação partidária para que houvesse maior influência no movimento estudantil ${ }^{147}$ e de outro, a influência artística e política de Ruggero Jacobbi para os jovens militantes. Entretanto, é importante assinalar, o TPE nunca foi subsidiado pelo PCB e nem considerado como um núcleo de ação partidária, sendo antes uma atividade paralela de militância cultural. No dia 5 de abril de 1955, em reunião ocorrida na casa dos pais de Vianinha, na Rua Epitácio Pessoa - muito próxima à Rua Teodoro Bayma, onde era a sede do Teatro de Arena - foi fundado o Teatro Paulista do Estudante.

Consta na ata de fundação que Vianinha convidou Ruggero Jacobbi para presidir a reunião. Há uma lista das pessoas que compareceram ao ato inaugural: Oduvaldo Vianna Filho; Gianfrancesco Guarnieri; Pedro Paulo Uzeda; Julio Elman; Raymundo Duprat; Diorandy Vianna; Mariúsa Vianna; Maria Estela Rodrigues; Natacha Roclavin; Silvio Saraiva e Ruggero Jacobbi.

É difícil apresentar um retrato nítido de cada um dos integrantes desse primeiro núcleo de trabalho do TPE. São pessoas de origens diversas. Pedro Paulo Uzeda

\footnotetext{
${ }^{146}$ Trecho de entrevista inédita de Guarnieri concedida a Alessandra Vannucci em junho de 1997.

${ }^{147} \mathrm{O}$ pesquisador Dênis de Moraes afirma que o Partido convocou diretamente os jovens para criarem um grupo de teatro amador com a missão de aproximar a classe estudantil. (MORAES, D. Vianinha cúmplice da paixão. Rio de Janeiro: Ed. Record, 2000, p. 55). O autor conta, por exemplo, que Vianinha intimou Vera Gertel, sua então namorada que estudava para o vestibular de medicina, a participar do grupo em formação e que, diante de sua hesitação, teria lhe dito que ela estava obrigada a participar pois se tratava de tarefa do Partido (p. 47).
} 
Moreira, por exemplo, de acordo com Guarnieri fazia parte da organização política do PCB junto com eles. Era da mesma idade que Guarnieri - nascido em 1934 - e tornaram-se grandes amigos ${ }^{148}$. Raymundo Victor Duprat foi ator em diversas montagens do GTA (Grupo de Teatro Amador de São Paulo), fundado em 1950 por Evaristo Ribeiro, Eny Autran e Clovis Garcia, estudantes da Faculdade de Direito. Ao que parece, todos tinham clareza sobre o sentido da tarefa.

Chama atenção a presença majoritária da família Vianna no encontro. Diorandy e Mariúsa eram primos de Vianinha. Cresceram os três como irmãos. Filhos de Jayrê, irmão de Oduvaldo Vianna, e Maria. Jayrê não partilhava dos ideais comunistas do irmão e as discussões ideológicas eram constantes na família ${ }^{149}$. Quando os filhos Mariúsa e Diorandy começaram a fazer teatro no TPE, Jayrê não gostou nem um pouco e talvez isso tenha influenciado para que anos mais tarde os dois seguissem outras carreiras. Mas Mariúsa, a partir do TPE, ainda seguiu como atriz por alguns anos, entrou para o Teatro de Arena junto com seus colegas e fez espetáculos até $1957^{150}$.

O que se destaca dessa primeira reunião de fundação do grupo era o vínculo entre história familiar, interesses culturais e militância comunista, sobretudo nos casos de Vera Gertel, Vianinha e Guarnieri. Eles seriam os principais mobilizadores do TPE,

\footnotetext{
${ }^{148}$ Pedro formou-se em medicina pela Universidade de São Paulo, em 1958. Foi um dos precursores do Psicodrama no Brasil, desde o final da década de 1960. Dizia que a experiência com o TPE tinha sido muito importante para a direção "dos afetos artísticos científicos no sentido da psiquiatria, dentro da medicina" (UZEDA, P. P. Apud CEPEDA, N. A.; MARTIN, M. A. F. MASP 1970: o psicodrama. São Paulo: Ágora, 2010, p. 148). Pedro Paulo Uzeda foi o psicanalista de muitos militantes do PCB e de artistas de esquerda.

${ }^{149}$ VIANNA, D. Companheiros de viagem. São Paulo: Editora Brasiliense, 1984. Quando Oduvaldo concorreu para deputado estadual, Jayrê teria dito que votaria no irmão, não no comunista.

${ }^{150}$ Foi lá que ela conheceu Sérgio Rosa, produtor do Arena, e com ele se casou. Tiche Vianna em entrevista para essa pesquisa contou que a mãe costumava falar sobre a direção de Ruggero em A Rua da Igreja, dizendo que tinha um caráter mais abrangente, teórico. E falava sobre a direção de Augusto Boal, mais para a direção de atores. Os dois a impressionaram muito. Ela tornou-se psicóloga e Diorandy, advogado. Mariúsa morreu muito jovem. Mas, para desespero do avô, como dirá Deocélia, Mariúsa teve uma filha, a Beatriz Vianna (Tiche) que seguiu a vocação teatral da família. A convivência com Deocélia teria sido determinante na formação artística e política de Tiche. Ela que teria indicado as leituras "obrigatórias", toda série comunista de Jorge Amado, teoria marxista, além de levá-la a manifestações.
} 
configurando-se como lideranças do projeto. Tinham sido também, não por acaso, lideranças da Juventude Comunista, entidade estudantil secundarista ligada ao Partido.

Lincoln Secco, em documentário sobre Marighella, atenta para o fato de que ser comunista no período entre 1930 a 1965 significava aderir a uma "causa profunda", era de alguma forma participar do "exército mundial da Revolução". E que mesmo que aqui no Brasil esse "exército" fosse frágil, ele representava o interesse numa revolução real. "Ser comunista tinha um peso ontológico, era doar a vida por uma causa"151.

Os três jovens militantes interessados eram, também, herdeiros de um movimento iniciado na década de 1930 em que o intelectual brasileiro se viu obrigado, segundo Antonio Candido, diante da crise do mundo liberal, a tomar partido entre o comunismo e o fascismo. Cresceram em ambientes para quem o posicionamento político manifesto era uma obrigação intelectual ${ }^{152}$. E ser ligado ao PC era, para esses grupos, também modificar a compreensão corrente sobre "cultura brasileira", agora levada a participar daquele imaginário de superação das injustiças sociais num caminho de aproximação ao "o homem simples", na busca pela compreensão de sua realidade e “mentalidade" "153 . Como apontado em um famoso ensaio de Octávio Ianni:

O que torna as artes as ciências sociais dos últimos tempos uma manifestação fundamental da cultura brasileira, é o fato de que eles estão preocupados com os dilemas dessas pessoas. Os seus personagens são os homens simples. No campo ou na cidade, elas estão voltadas para os anônimos, aqueles que trabalham com as mãos. Os homens e as mulheres, as crianças e os velhos retratados e

\footnotetext{
${ }^{151}$ Depoimento de Lincoln Secco para o filme Marighella de Grinspum Ferraz, Downtown Filmes, 2012.

${ }^{152}$ Depoimento de Antonio Candido para o filme Marighella de Grinspum Ferraz, Downtown Filmes, 2012.

${ }^{153}$ IANNI, O. A mentalidade do homem simples. Revista Civilização brasileira. Rio de Janeiro. Número 18, Ano III, mar.-abr. 1968, p. 114.
} 
estudados são os humilhados e ofendidos que povoam a fazenda e a fábrica, o mocambo e a favela, as casas de culto e os botequins. Nesses lugares, acompanhamos os atos e os pensamentos, as lutas e os desalentos dos caboclos e operários. ${ }^{154}$

E é nesse sentido que Marcelo Ridenti, no texto Brasilidade vermelha, demonstra que a organização do Partido Comunista, ainda que contraditória, foi de extrema importância "para as lutas nos meios artísticos e intelectuais no período"155, cujas obras significativas e imaginário de esquerda se tornariam hegemônicos na produção dos anos $60^{156}$, mas que não poderiam ser pensadas como desarticuladas das ideias dos comunistas desde a década de 30 .

Com efeito, muitos dos jovens que na década de 1950 impulsionaram um movimento artístico de esquerda eram quadros do Partido Comunista Brasileiro. E foram eles, principalmente, que:

Ajudaram a construir certa utopia da brasilidade libertadora no cinema, no teatro, nas artes plásticas, na arquitetura, na literatura, no

\footnotetext{
${ }^{154}$ Id. Ibid., p. 114. - O autor identifica nas artes e nas ciências sociais algumas obras exemplares dessa busca pelo homem simples e que revelam esse mesmo sentido de compreensão, o misticismo e a violência. No cinema ele cita Vidas Secas (1963), de Nelson Pereira do Santos, Deus e o diabo na terra do sol (1964), de Glauber Rocha, entre outros. Na literatura dramática ele lembra de Eles não usam Black- tie (1958), do Guarnieri, e Revolução na América do Sul (1960), de Augusto Boal. Na literatura Vidas Secas (1938), de Graciliano Ramos, Morte e vida severina (1967), de João Cabral de Mello Neto, Grande sertão: veredas (1956), de Guimarães Rosa. Na música ele cita os personagens das canções de Caetano Veloso, Geraldo Vandré, Chico Buarque, entre outros. Também cita estudos sociológicos de autores como Antonio Candido, Florestan Fernandes, Juarez Brandão Lopes, Luiz Pereira, Maurício Vinha de Queiroz e Roberto Cardoso.

${ }^{155}$ RIDENTI, M. Brasilidade vermelha: artistas e intelectuais comunistas nos anos 1950. In: BOTELHO, A.; BASTOS, E. R.; VILLAS BÔAS, G. (Org.) O moderno em questão - A década de 1950 no Brasil. Rio de Janeiro: Topbooks, 2008, p.170.

${ }^{156}$ Cf. SCHWARZ, R. Cultura e política, 1964-1969. In: Paulo: Companhia das Letras, 2008, pp. 70-111. . O Pai de Família e outros estudos. São
} 
ensaio e na imprensa, esboçando a possibilidade de uma modernidade alternativa àquela que viria a se instalar após o golpe de $1964{ }^{157}$.

No âmbito teatral, a trajetória dos fundadores do TPE, com Vianinha, Guarnieri e Vera Gertel, que viriam a se juntar ao Teatro de Arena, impulsionando seu processo de politização, é exemplar dessa influência comunista. Os três jovens não apenas eram ligados ao Partido Comunista, em sua base secundarista, como seus familiares, há muito, também o eram.

$$
\begin{aligned}
& \text { As mudanças no PCB dos anos } 1960 \text { - que contribuíram para o } \\
& \text { florescimento cultural e político brasileiro na época - vinham sendo } \\
& \text { lentamente maturadas no período em que ainda prevalecia o } \\
& \text { stalinismo }^{158} \text {. }
\end{aligned}
$$

Os pais de Vianinha, por exemplo, Oduvaldo Vianna e Deocélia Vianna, foram militantes engajados do Partido Comunista até o fim de suas vidas e ambos mantiveram um trabalho artístico importante e constante, preocupado com a questão do acesso popular. A dedicação com que ambos levaram a vida de artistas e de militantes do Partido Comunista certamente afetou as escolhas estéticas e o engajamento político de Vianinha. Oduvaldo foi um expoente do teatro profissional, da rádio e do cinema. Tinha grande intimidade técnica com métier de uma dramaturgia cômico-sentimental, nos padrões da alta comédia de costumes modernizada. Trabalhou para instaurar no teatro a prosódia brasileira. No fim da década de vinte e durante a década seguinte suas comédias de costume faziam enorme sucesso, como ocorreu a muitos dos artistas que se

\footnotetext{
${ }^{157}$ RIDENTI, M. Op. Cit., 2008, p.170.

${ }^{158}$ Id. Ibid., p. 175.
} 
celebrizaram em torno dos espetáculos apresentados no Teatro Trianon ${ }^{159}$ no Rio de Janeiro.

Oduvaldo Vianna era simpatizante do Partido Comunista desde inicio dos anos 1930. Deocélia antes de se casar com Oduvaldo foi sua secretária pessoal, trabalhava como datilógrafa para ele em São Paulo. Ao contrário dele, a esposa era de origem operária. Em 1934, Oduvaldo resolveu se mudar para o Rio de Janeiro, para lançar a peça Amor, no Teatro Rival, que estava sendo construído com três palcos especialmente para essa montagem. Amor se valia formalmente da ideia de planos espaciais diferentes, com uso de flashbacks, que, anos depois, iria se consagrar na montagem de Vestido de Noiva, de Nelson Rodrigues. Para que Deocélia não ficasse desempregada, uma vez que não tinha intenções de se mudar para o Rio de Janeiro, Oduvaldo a apresentou para os responsáveis pela Editora Cultura Brasileira ${ }^{160}$, editora comunista, que ficava na Rua Líbero Badaró, em São Paulo. Ela começa a trabalhar para essa editora que publicava muitas traduções, principalmente do francês, literatura soviética, com destaque para Máximo Gorki e outras obras proletárias, divulgadas pelos partidos comunistas dos Estados Unidos e da França ${ }^{161}$.

Deocélia Vianna relata em sua autobiografia, Companheiros de viagem, que foi trabalhando ali que teve conhecimento, por exemplo, do emblemático livro de John Reed sobre a revolução russa, Os dez dias que abalaram o mundo, que havia acabado de ser publicado pela editora e de obras como Judeus sem dinheiro, de Michel Gold (que

\footnotetext{
${ }^{159}$ Oduvaldo escrevia textos para serem encenados pelos atores mais importantes da cena carioca, como Procópio Ferreira e Jayme Costa. Sua peça Amor fez sucesso internacional em 1934, estrelada pela Cia. Dulcina Odilon, e foi a consagração da sua carreira.

${ }^{160}$ ROXO, M.; SACRAMENTO, I. Intelectuais partidos: os comunistas e as mídias no Brasil. Rio de Janeiro: Editora E-Paper, 2012, p.60. Os autores apresentam algumas editoras e livrarias brasileiras que publicavam textos comunistas e soviéticos no início da década de 30. No Rio de Janeiro havia, por exemplo, a Civilização Brasileira e a Editora Calvino. Em São Paulo, as editoras Sabrania, Unitas, Pax e a Editora Cultura Brasileira.

${ }^{161}$ Id. Ibid., p. 60.
} 
na década de trinta era um dos principais colunistas do Daily Worker, jornal do Partido Comunista Americano ${ }^{162}$ ), que circulou entre todos os comunistas da época.

Nesse mesmo ano, 1934, a polícia fechou as portas da livraria, prendendo todos os editores e apreendendo todo o material, com prisão de comunistas. Ela, que não estava no trabalho nesse e dia e por pouco escapou da prisão, guardou para sempre aquela cópia do livro de John Reed ${ }^{163}$.

É difícil mapear as influências estético-culturais da geração de comunistas imediatamente anterior a Vianinha, Guarnieri e Vera Gertel. É certo, entretanto, que mesmo aqueles que não pensassem em pôr seu teatro ou literatura a serviço da luta social, sabiam das inquietações mundiais nesse campo. Nesse sentido, mesmo nas coordenadas incertas dos ambientes intelectualizados do Rio de Janeiro e de São Paulo, essa geração tomou contato com os debates em torno do papel do artista antifascista e do Realismo Socialista.

1934 foi o ano em que foram fixadas as bases para o Realismo Socialista no $1^{\circ}$ Congresso de Escritores Soviéticos, que viriam a pautar na Europa a produção literária da esquerda dos anos seguintes. E, analogamente, a tática da Frente Popular, lançada no VII Congresso da Internacional Comunista (entre julho e agosto de 1935, em Moscou), foi assumida pelos partidos comunistas do mundo todo ${ }^{164}$. As teses do realismo socialista ganharam força no Brasil principalmente durante a segunda guerra mundial, nos anos 1940. O Partido Comunista Brasileiro aceitou as premissas da Frente como política cultural, tendo em vista a divulgação dos ideais comunistas para as massas ${ }^{165}$.

\footnotetext{
${ }^{162}$ Id. Ibid., p. 61.

${ }^{163}$ Depoimento de Tiche Vianna para essa pesquisa, São Paulo, 7 de julho de 2016.

${ }^{164}$ MORAES, D. O imaginário vigiado - a imprensa comunista e o realismo socialista no Brasil (19471953). Rio de Janeiro: José Olympio, 1994.

${ }^{165}$ Cf. FERNANDES, K. P. O povo é arte: as ilustrações em periódicos do PCB e o realismo socialista no Brasil. Anais do XXVI Simpósio Nacional de História - ANPUH. São Paulo, julho 2011. A teoria da
} 
Em 1949, por exemplo, a Revista Problema do PCB publicou o texto As tarefas da literatura na sociedade soviética de Andrei Zhdanov, braço direito de Stalin e o principal propagador do realismo socialista. Em determinado trecho se explicita a orientação estética:

Mostrar essas grandes virtudes novas dos homens soviéticos, mostrar nosso povo, não somente como é hoje, mas como será amanhã iluminar com um projetor o caminho que está à frente, - tais são as tarefas de todo escritor soviético honesto. O escritor não pode ficar a reboque dos acontecimentos, deve marchar na vanguarda do povo, mostrando-lhe o caminho de seu desenvolvimento! Inspirando-se nos métodos do realismo socialista, estudando conscientemente $\mathrm{e}$ atentamente nossa realidade, esforçando-se por penetrar mais profundamente na essência de nossa evolução, o escritor deve educar o povo e armá-lo ideologicamente. [...] Os escritores soviéticos devem ajudar o povo, o Estado, o Partido a educar nossa juventude corajosa e confiante em suas forças, sem temer quaisquer dificuldades ${ }^{166}$.

Muitos intelectuais de esquerda no mundo ocidental participaram da Frente Popular, pela ideia de uma união antifascista. Mas outros, a exemplo de Brecht, nunca se identificaram realmente com essa ideia política, que pressupunha procedimentos

Frente Popular, na formulação de Lukács, partia da ideia de que não haveria revolução proletária na Europa naquele momento e que, sendo assim, necessitava-se um período de transição para a constituição cultural. Definia o conceito de "revolução democrática", "aproveitando o sentido revolucionário original da burguesia como elemento estratégico" (LUKÁCS, G. Apud BARRENTO, J. De Weimar a Moscovo, A teoria marxista do realismo e da literatura entre as duas guerras. In: __ (Org.). Realismo, materialismo, utopia (uma polêmica, 1935-1940). Lisboa: Moraes Editores, 1978, p. 16) fazendo dele o seu modelo para uma ação política, que aos poucos, se transformaria (de uma revolução burguesa) em revolução proletária. No entanto, Lukács, ao contrário do que se propaga sobre o assunto, não apadrinhou o realismo socialista. (Id. Ibid., p. 24).

${ }^{166}$ ZHDANOV, A. As tarefas da literatura na sociedade soviética. Problemas. Revista Mensal de Cultura Política n 20, ago.-set. 1949. 
artísticos, estilísticos e mesmo um método político, que não eram os seus ${ }^{167}$. De qualquer maneira, nesse contexto foi a visão da Frente Popular que saiu vitoriosa e seguiu determinante até os anos 1950. Como decorrência, quase tudo o que fugia a esse padrão não encontrava apoio dos Partidos Comunistas ao redor do mundo. Por outro lado, como ocorreu no Brasil, essas diretrizes não parecem ter sido de fato tão determinantes nos trabalhos dos maiores artistas e intelectuais, que muitas vezes apresentavam sua própria visão de mundo, ainda que ancorada, isso sim, na experiência de militância e na projeção de uma Revolução Socialista. Vidas Secas, por exemplo, uma obra prima de Graciliano Ramos, então ligado ao Partido, foi publicada em 1938. E não é possível afirmar que o romance seguisse estritamente orientações do realismo socialista, com uma visão positiva do sofrido, indicando o caminho para uma revolução. De modo indireto, a influência comunista surgia antes no imaginário mobilizado, na busca de um Brasil popular, dos dramas de proletários e camponeses, de qualquer modo afim a diversas correntes antiburguesas do modernismo.

Jorge Amado, o "artista comunista mais famoso de então" ${ }^{168}$, foi um grande divulgador do realismo socialista. Constantemente citava textos de "Jdanov e de Gorki em seus artigos na imprensa, o que demonstrava suas afinidades com os ideais"169. Seu livro Subterrâneos da liberdade é considerado, segundo informa Marcelo Ridenti, o exemplo mais bem acabado do que seria uma vertente realista socialista no Brasil. Ainda assim, Jorge Amado, teria dito que a influência em sua escrita era muito "mais

\footnotetext{
${ }^{167}$ Para Brecht, a ideia fundamental da Frente contradizia o ponto de vista de classe, determinante para uma arte política, em sua visão. Do mesmo modo, a política de alianças a partir de cima, controlando os meios artísticos e estilísticos a serem desenvolvidos nas produções, também soava contraditório com uma ideia de refuncionalização dos aparelhos produtivos, da instituição arte. (BARRENTO, J. (org.). Op. Cit., 1978, p. 23).

${ }^{168}$ RIDENTI, M. Brasilidade vermelha: artistas e intelectuais comunistas nos anos 1950. In: BOTELHO, A.; BASTOS, E. R.; VILLAS BÔAS, G. (Org.) O moderno em questão - A década de 1950 no Brasil. Rio de Janeiro: Topbooks, 2008, p. 175.

${ }^{169}$ Id. Ibid., p. 178.
} 
stalinista do que realista socialista", propriamente, sem que isso tivesse determinações diretas e objetivas:

Não sei se as visões eram as vigentes no PC. Eu acho que não, acho que eram besteiras mais minhas do que do PCB mesmo. Não houve nunca as linhas do PCB. Foram ler o romance alguns anos depois, quando eu o concluí, quando voltei da Europa, mas não fizeram corte nenhum ${ }^{170}$.

Seus livros eram leitura obrigatória para os comunistas, tanto para a geração de trinta, como para a de cinquenta. Guarnieri, por exemplo, conta que na época de sua juventude, dentre as poucas obras de literatura que conhecia, estavam as de Jorge Amado $^{171}$.

Haveria, de acordo com Ridenti, espaço para visões particulares. Isto é, a ideia de que a doutrina partidária decidia as diretrizes artísticas não é a verdade plena, afinal existiam mais aspectos contraditórios na relação. Ao mesmo tempo, algumas dessas obras eram lidas e avaliadas pelas figuras mais proeminentes do Partido, como Diógenes Arruda Câmara, que no exemplo do livro de Jorge Amado não fez nenhum "corte" cárcere, que Graciliano Ramos havia escrito narrando "sem fagulhas de panfleto sua prisão após o levante de $1935^{, 173}$. O levante referido era a Intentona Comunista, da qual Graciliano tomou parte e foi preso junto com tantos outros no presídio de Ilha Grande.

\footnotetext{
${ }^{170}$ AMADO, J. Apud RIDENTI, M. Op. Cit., 2008, p. 178.

${ }^{171}$ GUARNIERI, G. Apud KHOURY, S. Atrás da máscara. Rio de Janeiro: Civilização Brasileira, 1984. Volume 1. P. 22.

${ }^{172}$ RIDENTI, M. Op. Cit., 2008, p. 179.

173 MAGALHÃES, M. Marighella - o guerrilheiro que incendiou o mundo. São Paulo: Companhia das Letras, 2012, p. 220.
} 
Por conta disso, a obra foi publicada apenas postumamente, em 1953, sem que o autor a houvesse concluído ${ }^{174}$.

O ponto realçado por Ridenti é de que havia contradições nas relações entre as diretrizes partidárias, geralmente dogmáticas e sectárias, e as práticas dos artistas e intelectuais ligados ao Partido. De um lado, a visão já caricatural de que os artistas mantinham dentro do partido uma posição basicamente "ornamental" e "instrumental" para fins de publicidade política, ou para prestigiar o Partido ou na divulgação de "sua linha política" ${ }^{\prime 75}$ - isso até o final da década de 50, quando realmente se encerrou a influência stalinista. Mas, de outro lado é importante que se observem as “contrapartidas" que o Partido oferecia aos artistas e intelectuais ${ }^{176}$, que podiam ser entendidas basicamente em termos do imaginário que o Partido representava, cujas bases, na União Soviética, eram efetivamente operárias. O caminho do comunismo era o caminho por uma sociedade mais justa, menos desigual.

Em 1945, por exemplo, no único período de legalidade do PCB, Oduvaldo Vianna concorreu a um cargo de deputado Estadual. Essencialmente, a candidatura de Oduvaldo Vianna serviu para dar visibilidade ao Partido, como ele mesmo sabia ${ }^{177}$. Por outro lado, possibilitou ao dramaturgo aproximação de maneira mais concreta com parcelas da classe popular do ângulo da luta pelos trabalhadores. O vínculo com o PCB ajudou a concretizar o imaginário de luta e justiça social daquele e de tantos outros artistas. Ao menino Vianinha, a participação política dos pais era um dado da vida

\footnotetext{
${ }^{174}$ Id. Ibid., p. 220.

175 RIDENTI, M.. Op. Cit., 2008, p. 175.

${ }^{176}$ Id. Ibid., p. 175.

177 VIANNA, D. Companheiros de viagem. São Paulo: Editora Brasiliense, 1984, p. 87 - Oduvaldo não foi eleito, mas teve considerável número de votos. Segundo Deocélia: "O Partido elege uma bancada federal e estadual das mais expressivas e devotadas, salvo algumas exceções, é claro. Era aquela euforia, aquele entusiasmo. Oduvaldo recebe 2600 votos. Uma ótima votação. Seu orgulho era ser suplente de Mário Schemberg”.
} 
prática. Com 10 anos de idade foi fazer comício para a candidatura de Oduvaldo na Avenida Ipiranga ${ }^{178}$.

A geração de Vianinha, ao reelaborar a experiência da geração anterior, procurou conjugar as duas instâncias, arte e política, de modo mais mobilizador de lado a lado, rompendo dualismos, num momento em que as condições históricas assim permitiam. E Vianinha, mais tarde, assim como seu pai, buscou se aproximar dos meios de cultura de massa, ainda incipientes no Brasil. A rádio foi um exemplo onde houve forte inserção comunista, bastante impulsionada por Oduvaldo Vianna, que fez parte da primeira geração comunista a aderir ao veículo de comunicação. Quando voltaram a viver em São Paulo, em 1940, Oduvaldo Vianna assumiu de vez a carreira de radialista. Inaugurou a rádio Panamericana e criou uma célula do Partido na rádio Tupi, de Assis Chateaubriand, com diversos artistas comunistas, como Dias Gomes e Mario Lago. Em entrevista para Marcelo Ridenti, Dias Gomes, contou que nos anos 1940 foi trabalhar na rádio:

e lá conheci Oduvaldo Vianna, que naquele momento estava organizando uma célula do Partido Comunista na rádio Tupi de São Paulo, por influência dele eu entrei no Partido [...] nós todos éramos militantes mesmo, militantes de rua, de pichar muros etc. e tal. ${ }^{179}$

Oduvaldo tinha uma crença na capacidade de difusão cultural (e política) que a rádio poderia trazer. A rádio atingia milhões de pessoas, muito mais que o teatro e,

\footnotetext{
${ }^{178}$ Assis Chateaubriand era dono de um império das comunicações, com jornal impresso, rádio e, desde 1950, a TV TUPI. Era uma figura contraditória, amante das artes e um grande mecenas. Foi ele quem fundou o MASP, em 1947. Sempre soube da opção ideológica de Oduvaldo e em certa medida aceitou. Isso só realmente foi um problema na ditadura militar, que acabou levando muitos comunistas a serem demitidos e dentre eles Oduvaldo. Depois, quando integralistas denunciaram Oduvaldo - e tantos outros intelectuais - de ser agente secreto de Moscou e de estar sabotando a defesa das Américas em caso de guerra, Chateaubriand ofereceu a Oduvaldo uma pagina inteira de resposta em seu jornal. (VIANNA, D. Companheiros de viagem. São Paulo: Editora Brasiliense, 1984, p.106)

${ }^{179}$ GOMES, D. Apud RIDENTI, M. Op. Cit., 2008, p.182.
} 
proporcionalmente, a um custo muito menor. Não havia ali, como também não haveria na década seguinte, uma desconfiança quanto à indústria cultural ou à mercantilização da arte gerada pela própria estrutura produtiva. Vianinha também procuraria, de modo mais ou menos ingênuo, fazer da televisão um reduto de comunistas ${ }^{180}$. Ambas as gerações viam ali uma possibilidade real de se aproximar do povo.

Deocélia Vianna também exerceu forte influência em Vianinha. Após alguns anos de contato com o trabalho cultural, assumiu a vida como escritora de radionovelas e de programas femininos diários na radio, como Papinho com dona Genoveva. Ela também escreveu textos dramatúrgicos. Quando se aproximou do Partido Comunista, aderiu de forma apaixonada. Em seus programas nas rádios falava sobre a condição de vida dos trabalhadores, sobre a desigualdade social, a situação das mulheres, sobre educação. Em sua autobiografia se vê o senso ético e de justiça com que conduzia a vida. Em 1947 foi designada pelo Partido para participar da Federação das Mulheres, entidade ligada a Federation Internationale de Femme - Marie Claude Vaillant Couturier. A federação congregava operárias, donas de casa e intelectuais ${ }^{181}$.

A casa dos Vianna era ponto de reunião dos dirigentes do Comitê Central (CC) e comitê estadual (CE): Agildo Barata, Armênio Guedes, Câmara Ferreira Pacheco, José Maria Crispim, João Massena. Vianinha participava de ações junto com seus pais, como quando organizavam eventos para arrecadar fundos ao Partido ou para exilados político, em caminhadas para recolher assinaturas pela paz ou pedindo doações para presos e seus familiares etc.

Vianinha alistou-se nos quadros da Juventude Comunista em 1950. Logo começou a escrever para o jornalzinho da juventude do Partido.

\footnotetext{
${ }^{180}$ Cf. RIDENTI, M. Op. Cit, 2008, p.182.

${ }^{181}$ VIANNA, D. Op. Cit., 1984, p. 88.
} 
O trabalho dos militantes da Juventude Comunista consistia, entre outras coisas, naquele momento, em tentar mobilizar os estudantes secundaristas, em organizar protestos contra os acordos militares entre Brasil e Estados Unidos na guerra da Coreia e ações para a campanha do Petróleo é Nosso ${ }^{182}$.

Vianinha conheceu Vera Gertel quando entrou de "penetra" na festa em que ela tinha organizado para comemorar seus 15 anos. O rapaz se impressionou com a foto que tinham de Prestes em cima do piano e quis se aproximar da moça. Logo começou uma relação que durou poucos anos como casados e muitos anos como parceiros de criação $^{183}$.

A trajetória pessoal de Vera Gertel, num certo sentido, também se confunde com os movimentos do Partido Comunista no Brasil. Vera é filha de um intelectual e uma operária, à semelhança dos Vianna. Noé Gertel - jornalista e importante figura do Partido Comunista - e Rachel Gertel, operária tecelã, escritora e também militante. Nasceu no intenso ano de 1937. A mãe, curiosamente, queria que seu nome fosse Anéli, uma homenagem à extinta ANL (Aliança Nacional Libertadora). Mas o pai, no momento de registrar a filha ficou com receio de que o escrivão desconfiasse sobre a origem do nome e a registrou como Vera.

Em 1939 Noé Gertel foi preso pelo Estado Novo por subversão e condenado a cinco anos, três dos quais passou na famosa prisão de Ilha Grande ${ }^{184}$. Junto com ele

\footnotetext{
${ }^{182}$ MORAES, D. Vianinha cúmplice da paixão. Rio de Janeiro: Ed. Record, 2000, p. 41

${ }^{183}$ Quando se casaram os padrinhos de Vera foram o jornalista comunista Joaquim Câmara Ferreira e sua esposa Leo. Do lado de Vianinha foram Guarnieri e a prima de Vianinha, a Mariúsa. (GERTEL, V. Um gosto amargo de Bala. Rio De Janeiro: Civilização Brasileira, 2013, p. 100).

${ }^{184}$ ANTONACI, G. A. Os presos comunistas nos cárceres da Ilha Grande (1930-1945). Dissertação (mestrado em História) - Instituto de Ciências Humanas e Filosofia, Universidade Federal Fluminense, Niterói, 2014. Noé Gertel entrou para o PCB em 1931, quando ainda cursava direito no Largo São Francisco em São Paulo. Ele participou do ato que dissolveu a marcha integralista em 1934 e tendo sido reconhecido por um soldado precisou entrar para a clandestinidade. Isso teria garantido que ele só fosse preso em 1940 e não em 1935, na época da Intentona Comunista. P. 106. Quando foi finalmente solto, em 1944, a família viveu em clandestinidade, passando de pensão em pensão. Noé e Rachel, por falta de recursos financeiros, viveram separados por alguns anos. Rachel trabalhava como jornalista e repórter do jornal comunista Hoje.
} 
estavam figuras das mais proeminentes do Partido, como Marighella, Jorge amado, Gregório bezerra, Joaquim Camara Ferreira, Bangu e Agildo Barata. Um fato curioso foi terem criado um grupo de teatro no presídio, a que deram o nome de "Teatro de Brinquedo", aludindo ao grupo de Álvaro e Eugênia Moreyra. Encenavam autores brasileiros e "esquetes sobre a agenda política do momento, em especial a guerra na Europa". Mário Magalhães comenta o repertório dos prisioneiros ilustres em sua biografia sobre Marighella:

O capitão Agildo Barata adaptou Monteiro Lobato para fantoches. Apresentara Deus lhe pague, de Joracy Camargo. Gastão Tojeiro, de Onde canta o sabiá, foi dos dramaturgos mais montados. Como o presídio era masculino, faltavam atrizes. Certa feita Marighella interpretou uma tia velha e Gregório Bezerra, uma empregada de avantajados glúteos postiços ${ }^{185}$.

Desde cedo Vera conheceu o lado difícil da vida de militante comunista. Viveram anos na clandestinidade e com pouquíssimos recursos financeiros. Ainda assim, optou pela militância. Participou de entidades estudantis, grêmio e associações. Foi vice-presidente da Upes (União Paulista dos Estudantes Secundaristas) e membro da Juventude Comunista do Partido. Mas o momento em que ela aderiu ao Partido, em 1950, era de refluxo, de saída de muitos intelectuais e de isolamento em relação às massas. Posto na ilegalidade em 1947, depois de um breve período legal (em 1945), o Partido acirrou um posicionamento à esquerda, mas que na prática esvaziou a sigla e distanciou-a de trabalhadores e estudantes. O ápice desse movimento interno do Partido, em consonância com a postura da União Soviética na Guerra Fria, foi o Manifesto de

\footnotetext{
${ }^{185}$ MAGALHÃES, M. Op. Cit., p. 120. Muitos dos autores e atores do teatro profissional tinham simpatia
} pelo Partido Comunista, como Procópio Ferreira, Joracy Camargo e Gastão Tojeiro. 
Agosto, de 1950, assinado por Luís Carlos Prestes em nome do Comitê Central do PCB. Tratou-se de uma tentativa de traçar uma linha revolucionária para o Partido que, alheio às circunstâncias nacionais, pregava o "armamento geral do povo" e defendia a criação de um "exército popular de libertação nacional"186 . Com efeito, foi um período de forte sectarismo. Em sua autobiografia, Vera reflete sobre o esvaziamento da entidade estudantil naqueles anos:

A militância (em pleno "Manifesto de Agosto") era a mais paralisada possível. A ação de liderar uma greve teve, para a inexperiente menina de 13 anos, a consequência de ser eu a única participante ${ }^{187}$.

Foi em decorrência de um congresso da União Paulista dos Estudantes Secundaristas (em que ela foi acompanhada de sua mãe), em Sorocaba, que Vera Gertel conheceu Guarnieri. Ambos haviam sido eleitos vice-presidentes da entidade, em uma assembleia marcada por desentendimentos entre os de "direita" e os de "esquerda" e um misterioso sumiço da urna ${ }^{188}$. Vera Gertel descreve as primeiras impressões sobre Guarnieri e sobre a relação dos dois com o movimento estudantil:

era um garoto doce, simpático, amistoso, bom de discurso e senso comum. Logo ficamos amigos. Sempre que o DOPS aparecia para acabar com nossas assembleias, Guarnica ou Cecco - seus apelidos se aproveitava da baixa estatura para ser expulso da sala como menor de idade, por determinação policial ${ }^{189}$.

\footnotetext{
${ }^{186}$ FEDERICO, Celso. A política cultural dos comunistas. In: MORAES, J. Q. História do Marxismo no Brasil. São Paulo: Editora Unicamp, 2007. Volume III.

${ }^{187}$ GERTEL, V. Um gosto amargo de Bala. Rio De Janeiro: Civilização Brasileira, 2013, p. 68.

${ }^{188}$ Id. Ibid., p. 71.

${ }^{189}$ Id. Ibid., p. 72.
} 
As influências familiares na vida de Gianfrancesco Guarnieri também foram fundamentais para sua trajetória posterior. Nascido em Milão em 1934, seus pais eram músicos eruditos, com carreiras consagradas. O maestro Edoardo Guarnieri e Elsa Martinenghi, harpista, decidiram vir para o Brasil em 1936 - fugindo do governo fascista de Mussolini - e se estabeleceram no Rio de Janeiro. Elsa Guarnieri veio antes, com contrato para tocar na Orquestra Sinfônica Brasileira. No Brasil conseguiu convites de trabalho para o marido. Fizeram uma boa carreira aqui, o pai logo se interessou pela música brasileira - foi amigo de Heitor Villa-Lobos, segundo Guarnieri. Já nos primeiros anos de Brasil, Edoardo Guarnieri teria se aproximado de uma pequena célula do Partido Comunista no Rio de Janeiro. Guarnieri considerava que o pai era um comunista, embora não tivesse, segundo o filho, uma visão política clara. Seria antes, na realidade, um subversivo, "um cara que gostava de subverter" tudo:

Ele se uniu a esse grupo [célula do PCB] e, após os concertos no Municipal, ainda vestindo a casaca de regente, saía para pichar os muros da cidade ${ }^{190}$.

Desde cedo o menino Guarnieri assistia aos ensaios de orquestra e de ópera. Mais tarde atribuiria grande importância a esses eventos na formação de seu gosto e interesse por arte. Assistia, também, a espetáculos na Cinelândia, de Renato Vianna e, já adolescente, matava aulas para assistir a Jaime Costa nas Matinês do Teatro Glória: "[...] eu gostava mesmo das comédias, daquelas palhaçadas e confusões"191 . O trânsito entre a cultura erudita e a popular, a experiência crítica dos pais com o regime fascista e a aproximação ao ambiente do Partido Comunista faziam parte do convívio familiar.

\footnotetext{
${ }^{190}$ GUARNIERI, G. Apud ROVERI, S. Gianfrancesco Guarnieri. Um grito solto no ar. São Paulo: Imprensa Oficial, 2004, p. 19.

${ }^{191}$ Id. Ibid., p. 23.
} 
Segundo o próprio Guarnieri, sua primeira relação real com a vida popular surgiu dentro de casa, com Margarida, empregada doméstica que trabalhou ali. Guarnieri relata que costumava ser levado por Margarida para as casas de parentes dela, nos cortiços "que já começavam a ganhar os morros" - episódio, este, exemplar das profundas contradições que envolvem as heranças coloniais e as relações cordiais tipicamente brasileiras ${ }^{192}$. Essas visitas e as relações travadas teriam causado grande impressão no menino Guarnieri, pelo choque de classe e discrepância social. A relação com Margarida e a mãe dela, uma senhora analfabeta chamada Romana, influenciaram diretamente na criação da personagem Romana de Eles não usam black-tie .

Ainda no colégio começou a fazer teatro, como ator e dramaturgo. Entrou para a Juventude Comunista nesse período e escreveu por alguns meses para o jornal Novos Rumos, ligado à organização. No curso normal ${ }^{193}$ Guarnieri passou a se dedicar com empenho ao Movimento Estudantil Secundarista, que precisava de novos quadros, "gente para distribuir panfletos, conquistar novos adeptos"194.

Nesse período foi nomeado presidente da Associação Metropolitana dos Estudantes Secundários e vice-presidente da União Nacional dos Estudantes Secundários. Em 1953 mudou-se junto com seus pais para São Paulo, onde seguiu e aprofundou o vínculo com o Partido, dedicando-se com tanto afinco à Juventude Comunista a ponto de se desinteressar pelo teatro.

Guarnieri e Vianinha se conheceram em uma célula cultural do Partido. É interessante observar que os três principais fundadores do Teatro Paulista do Estudante tinham opiniões muito semelhantes quanto às dificuldades das práticas militantes entre os secundaristas no período. A Juventude Comunista, que deveria "servir aos interesses

\footnotetext{
192 Id. Ibid., p. 24.

${ }^{193}$ É um curso secundário, equivale nos moldes atuais, a um curso profissionalizante em três anos em alguns estados e em quatro em outros.

${ }^{194}$ Id. Ibid., p. 33.
} 
dos estudantes" e lutar por melhorias da educação "só fazia política"195, era muito sectária, não aceitava pluralidades, o que correspondia a um período de grande isolamento político do Partido.

A partir de 1954, com o suicídio de Getúlio Vargas, o Partido Comunista parte para uma nova etapa em sua atuação política, o que tem desdobramentos na intensificação de suas atividades na área cultural. Volta à pauta o interesse em alianças com setores da burguesia, com movimentos sociais e sindicatos que sairiam às ruas contra a ascensão da direita ${ }^{196}$. Como resultado parcial dessa transformação, entidades do movimento estudantil como a União Metropolitana de Estudantes Secundários (UMES) e a União da Juventude estimulam os membros a atuarem em esferas culturais como outra forma de fazer política e assim angariar "novos quadros"197.

Aos poucos, o PCB abandona os preceitos do Manifesto de Agosto ${ }^{198}$, conseguindo, com isso (e não sem muitas contradições), se aproximar de uma ampla frente social que tinha como norte um desenvolvimento nacional e a campanha democrática pelas reformas de base.

\footnotetext{
Abandonando a posição assumida nas eleições de 1950, de voto em branco no pleito presidencial, o PCB apoiou em 1955 a candidatura de Juscelino Kubitschek pela chapa do Partido Social Democrático e do Partido Trabalhista Brasileiro, que elegeu também João Goulart como vice-presidente ${ }^{199}$.
}

\footnotetext{
195 GERTEL, V. Op. Cit., 2013, p. 70.

196 MAGAlHÃES, M. Op. Cit., 2012, p. 230-1. Ver também: KONDER, L. A democracia e os comunistas no Brasil. Rio de Janeiro: Editora Graal, 1980.

${ }^{197}$ BETTI, M. S. A politização do teatro: do Arena ao CPC. In: FARIA, J. R. (Org.). História do teatro brasileiro 2. São Paulo: Editora Perspectiva e SESC/SP, 2013, p.176.

${ }^{198}$ RIDENTI, M. Op. Cit., 2008, p. 173

${ }^{199}$ Id. Ibid., p. 173.
} 
Nos anos seguintes, esse processo de transformação da linha do Partido se aprofundaria radicalmente a partir principalmente "das denúncias de Krushev sobre os crimes de Stálin” ${ }^{200}$, que desvela uma ferrenha crise nos Partidos do mundo inteiro e também no brasileiro. Com muitos intelectuais e artistas mais uma vez abandonando as fileiras do PCB. Houve mudança nas direções e nas orientações políticas, resultando, em março de1958, na Declaração de Março, em que o Partido reafirma as teses sobre o caráter nacional e democrático do processo de luta, que deveria se pautar primeiro pelo anti-imperialismo e antifeudalismo, para só depois colocar o socialismo em pauta. Guarnieri em entrevista que traduz sua visão posterior deixa claro, entretanto, que parte de sua geração se viu, a partir dali, mais comprometida com reformas de base do que necessariamente com uma reestruturação sistêmica:

O que marcou aquela geração foi a necessidade de promover mudanças sociais, de acabar com tanta desigualdade neste país, esta distribuição de renda absurda. ${ }^{201}$

O Teatro Paulista do Estudante, portanto, surge num momento muito especial do que se poderia chamar de um projeto comunista brasileiro, quando as energias da militância se voltam para a "consolidação e ampliação da legalidade e das liberdades democráticas, em aliança com outras forças progressistas” ${ }^{202}$, o que gera uma pauta menos ligada à ideia de ação revolucionária do que à de participação nas lutas populares progressistas.

\footnotetext{
${ }^{200}$ Id. Ibid., p. 173.

${ }^{201}$ GUARNIERI, G. Apud KHOURY, S. Atrás da máscara. Rio de Janeiro: Civilização Brasileira, 1984. Volume 1. P. 38.

${ }^{202}$ RIDENTI, M. Op. Cit., 2008, p. 174.
} 
É significativo que nas folgas dos ensaios de teatro do TPE, Guarnieri e Vianinha fizessem campanha para Juscelino Kubitschek, declamando poemas nacionalistas de Castro Alves no meio da Praça da Sé.

Assim, do ponto de vista das expectativas do Partido com a criação de um grupo de teatro amador, seria possível dizer que o surgimento do TPE trazia ao debate tanto a questão da instrumentalização da arte para fins políticos, como a da forma própria para a representação politizada, com base no diálogo ainda necessário com padrões difusos do realismo socialista, para quem a figuração do "homem simples" do Brasil teria que ser também a representação de um lutador do povo.

Em termos mais imediatos, o grupo surge com o objetivo de, por meio da arte, colaborar na propaganda política junto à juventude: era preciso ampliar os quadros entre os secundaristas. O TPE seria o "braço estético" de uma política estudantil, como consequência de seu vínculo com a ANES (Associação Nacional dos Estudantes), do movimento estudantil ligado ao Partido comunista, conforme afirma Guarnieri:

E dali então, surgiu a ideia de formação do Teatro Paulista do Estudante, que fizemos como uma missão muito mais de política estudantil, do que de fazer teatro realmente. ${ }^{203}$

A pesquisadora Maria Sílvia Betti, no importante artigo A politização do teatro: do Arena ao CPC, afirma que no TPE não havia, de início "nenhum objetivo de profissionalização teatral", estando a tarefa partidária "autoassumida" em primeiro plano $^{204}$.

\footnotetext{
${ }^{203}$ GUARNIERI, G. Apud KHOURY, S. Op. Cit., 1984, p. 63.

${ }^{204}$ BETTI, M. S. Op. Cit., 2013, p. 176.
} 
A primazia política do projeto se anuncia no ato de fundação do TPE a partir do estatuto com 48 cláusulas que definiam objetivos e ambições, grande parte delas relativas à destinação do trabalho, o desejo de "chegar às massas", de apresentar as peças nos diretórios estudantis, em clubes, escolas, nas praças públicas, portas de fábrica etc. De acordo com fragmentos localizados desse documento, destaca-se o objetivo de:

promover a divulgação da arte cênica em meio aos estudantes secundários e universitários; promover espetáculos periódicos destinados a seus sócios; colaborar com as iniciativas que contribuam para a solidificação de nossa cultura; promover a cooperação e a união entre os grupos de teatro amador e de ensino médio; incentivar por todos os meios a cultura da arte teatral; pronunciar-se quanto a todas as iniciativas que venham direta ou indiretamente contribuir para o desenvolvimento de seus objetivos ${ }^{205}$.

Tudo era incipiente, mas desde o início a vontade de romper com as barreiras de classe estavam presentes, a vontade de um teatro que se deslocasse de seu lugar convencional, refuncionalizado.

Ainda que isso não fosse enunciado de início, as tendências ideológicas ligadas à atividade partidária indicam que também estava em pauta, já no momento inaugural, um descontentamento com a dramaturgia disponível, que não dava conta da realidade crítica do país, sendo necessário um novo teatro nacional que expressasse "os anseios do povo".

\footnotetext{
${ }^{205}$ GUARNIERI, G. Relatório Fundação Vitae, 2005. Cópia de documento datilografado gentilmente
} cedido por Vanya Sant'Anna, viúva de Guarnieri. A íntegra do estatuto, contudo, não foi localizada. 
O auxílio pedido ao diretor italiano Ruggero Jacobbi, entretanto, deixaria mais complexa a linha do projeto em gestação ${ }^{206}$. Vera Gertel e Guarnieri relataram que Jacobbi insistia numa formação pessoal mais ampla para os integrantes, pedia para que lessem mais, para que conhecessem os clássicos da literatura mundial como Dostoievski e Tolstoi ${ }^{207}$. E que principalmente, lessem os autores brasileiros, antigos e modernos, como forma mesmo de conhecer o Brasil. Assim foram todos estimulados a ler as obras de José Lins do Rego, Machado de Assis, Graciliano Ramos, Martins Pena, Gonçalves Dias etc.

De acordo com Guarnieri, a ideia dos jovens para o primeiro espetáculo era encenar Gonzaga de Castro Alves, mas como não chegaram a um acordo resolveram novamente pedir ajuda a Ruggero ${ }^{208}$. O encenador italiano sugeriu uma peça irlandesa chamada A Rua da Igreja e participou pessoalmente como orientador durante o processo. Na procura de um lugar para ensaiar A Rua da Igreja, o TPE já estabelece uma parceria com o Teatro de Arena - cuja sede era nova. Um acordo que marcaria a história posterior do Arena se estabelece ali: em troca de um lugar para ensaios e para apresentações (que seriam às segundas-feiras), o TPE cederia atores como figurantes para os espetáculos do Arena (na prática, os atores do TPE só participaram como figurantes do espetáculo Escola de maridos em 1956).

A união contraditória entre o pensamento e a prática teatral de Ruggero Jacobbi e os interesses dos jovens e animados militantes da Juventude Comunista que procuraram o teatro como lugar de politização sugere muitas questões de uma relação sempre complexa entre arte e política. Ruggero Jacobbi, durante toda sua estada no

\footnotetext{
${ }^{206}$ Sobre isso ver depoimento de Ruggero Jacobbi In: LERNER, Julio. A Aventura do Teatro Paulista. [Filme-vídeo]. Produção e entrevistas de Júlio Lerner. São Paulo, série de televisão produzida pela TV Cultura, 1981. VHS.

${ }^{207}$ Entrevista inédita de Guarnieri concedida a Alessandra Vannucci, 22.06.1997.

${ }^{208}$ GUARNIERI, G. Relatório Fundação Vitae, 2005. Cópia de documento datilografado gentilmente cedido por Vanya Sant’Anna, viúva de Guarnieri.
} 
Brasil, manteve uma postura independente em relação à possível instrumentalização partidária, mesmo próximo dos comunistas. Ele nunca foi filiado ao Partido Comunista. Bem mais tarde, em seu livro L'Avventura del novecento, ele se declara surrealistatrotskista-anárquico-libertário ${ }^{209}$. A declaração posterior, algo provocativa, indicava sua aproximação e interesse com uma vanguarda radical de esquerda, independente da doutrina do Partido Comunista, afinal foram os surrealistas e trotskistas que encamparam a primeira resistência das artes ao stalinismo ${ }^{210}$, enquanto as tendências anarquistas, talvez aqui referidas antes à visão estética do que à política, sempre se opuseram a burocratização da luta social. Sua resistência antifascista, seu conhecimento de Gramsci - que aludia à necessária independência da arte, sua não instrumentalização -, assim como seu gosto humanista clássico, o afastavam de uma concepção redutora como a das vulgatas do realismo socialista, ainda que ele próprio se interessasse pelo grande realismo. Sua aproximação com o Comitê Cultural do PCB naqueles anos só poderia se dar, portanto, numa situação de experimentação, de diálogo formativo com a juventude, numa área periférica e ao mesmo tempo tão passível de aberturas e interferências livres como o teatro.

\footnotetext{
${ }^{209}$ Apud RAULINO, B. Ruggero Jacobbi: presença italiana no teatro brasileiro. São Paulo: Perspectiva, 2002 , p. 49.

${ }^{210}$ O Manifesto por uma arte revolucionária e independente foi escrito por Andre Breton, Diego Rivera e Trotski em 1938 como documentação de fundação da F.I.A.R.I (Federação Internacional da Arte Revolucionária e Independente), um campo de resistência cultural a hegemonia do stalinismo nas artes e toda a retórica em defesa do realismo socialista. Um dos fundamentos do texto é a defesa da autonomia da arte e a crítica a instrumentalização defendida pelos PCs ao redor do mundo. Trotski já havia escrito em Literatura e Revolução que a "arte deve, em primeiro lugar, ser julgada segundo as suas próprias leis, isto é, as leis da arte" (TROTSKI, L. Literatura e revolução. Rio de Janeiro: Zahar Editores, 1969, p. 156). Antonio Gramsci, mais ou menos nesse mesmo período, fazia o mesmo tipo de consideração a respeito da arte. Ele respondia ao processo do fascismo, que procurava a seu modo também instrumentalizar a criação artística. Para Gramsci a arte precisa de autonomia, precisa enfrentar suas próprias regras e responder aos desejos, em ultima instância, do artista. Mas não pode desligar-se da sociedade que a engendra, de sua condição histórica. A arte é e reflete seu momento histórico: "a arte é sempre ligada a uma determinada cultura ou civilização, e que - lutando para reformar a cultura - consegue-se modificar o "conteúdo" da arte, trabalha-se para criar uma nova arte, não do exterior (pretendendo uma arte didática, de tese, moralista), mas do interior, visto que se modifica todo o homem na medida em que se modificam seus sentimentos, suas concepções e as relações das quais o homem é necessária expressão" (GRAMSCI, A. Literatura e vida nacional. Rio de Janeiro: Editora Civilização brasileira, 1968, p. 17).
} 
De qualquer maneira haverá uma espécie de sutil atrito entre os desejos de representação social, o imaginário brasileiro, daquela juventude engajada no Partido, e as orientações de Jacobbi, marcadas por ideias mais amplas sobre a questão nacionalpopular. A síntese elaborada pelo Teatro Paulista do Estudante haveria de ser provisória, e seus frutos mais importantes só amadureceriam após a fusão com o Teatro de Arena. 


\title{
Capítulo 4
}

\section{A RUA DA IGREJA: ESTREIA E IMPASSE}

A peça de estreia do TPE foi A Rua da Igreja, no dia 30 de maio de 1955.

Ocorreu no Teatro de Arena, já como ação de uma parceria que resultaria na fusão ocorrida no ano seguinte. Foi numa segunda-feira, às 21 horas, com entrada franca. Em texto para a Folha da Noite, Ruggero Jacobbi sublinhou a novidade que o grupo representava:

\begin{abstract}
há muitos anos estamos lutando pela constituição do TPE, isto é, um grupo de amadores capazes de realizar um programa não apenas "teatral" (no sentido da descoberta de vocações ou talentos), mas sim “cultural" e "popular" [...] realizando um esforço positivo no sentido de conquistar paulatinamente várias plateias, mais ou menos afastadas do teatro "oficial", começando pelo próprio público estudantil" ${ }^{211}$
\end{abstract}

Jacobbi destacou uma postura nova em relação ao ambiente teatral da época, uma disposição em alcançar outro público e, neste sentido, tensionar as fronteiras de classe da instituição teatral - por meio de um procedimento artisticamente moderno e popular. O TPE representava para Ruggero uma realização de fato avançada. A tal

\footnotetext{
${ }^{211}$ JACOBBI, R. A Rua da Igreja, Folha da Noite, 3.6.1955. In: Crítica da razão teatral. São Paulo: Perspectiva, 2005, p. 60. Foram mencionadas, por Ruggero, outras duas tentativas vindas de grupos estudantis: o grupo de teatro da politécnica, com Nossa cidade e o Doente imaginário; e o grupo de teatro da Faculdade de Direito, que teriam apresentado Corrupção no palácio da justiça, de Ugo Betti. Esse gesto situaria o TPE dentro de um novo movimento modernizador no teatro nacional, trazendo, nesse sentido, uma importante contribuição, "caracterizada por um espírito democrático singularmente vivo e lúcido". Ruggero havia produzido a montagem de Nossa Cidade do Grupo teatral da Politécnica, com direção de Osmar Cruz , que estreou em 1952 no teatro Leopoldo Fróes.
} 
ponto estava comprometido com o grupo que assumia não conseguir comentar a "estreia com a necessária objetividade"212. Depois de apresentar nominalmente todos que tomaram parte da montagem, enfatiza que o importante "no caso - é a equipe", a humildade e seriedade com que trabalharam, "longe da feira de vaidades", em que muitas vezes caem os $\operatorname{artistas}^{213}$. Termina o artigo citando uma passagem do programa da peça, expondo mais uma vez o que seria o real propósito do TPE:

O TPE é uma organização cultural e artística cuja finalidade precípua é levar o teatro, não só ao estudante, como também aos meios mais populares $^{214}$.

Aos olhos do crítico Ruggero Jacobbi parecem enfim reunidas as mais importantes prerrogativas para a efetivação de um projeto nacional popular para o teatro no Brasil, assim como idealizava desde o trabalho com o Teatro do Estudante e com o Teatro Popular de Arte.

A Rua da Igreja como imagem de um programa nacional popular

A peça A Rua da Igreja (Church Street) do autor irlandês Lennox Robinson foi indicada por Ruggero Jacobbi para a estreia do grupo. A escolha não foi aleatória, afinal é uma peça quase didática ao tematizar a própria função do artista no trato ficcional da realidade, entre o objetivo de representar particularidades locais e figurar o universal, sugerindo certa crítica ao ideal de um “cosmopolitismo" na arte. É uma peça que

\footnotetext{
${ }^{212}$ Id. Ibid., p. 60.

${ }^{213}$ Os grupos amadores na visão de Ruggero Jacobbi estariam mais aptos a combater a ideia de ator estrela, poderiam ousar mais e trabalhar efetivamente em equipe. Cf. JACOBBI, R. Critica e Indulgência, Folha da Noite, 22.11.1952. In: ___ Op. Cit., 2005, p. 4.

${ }^{214}$ JACOBBI, R. A Rua da Igreja, Folha da Noite, 3.6.1955. In: programa de A Rua da Igreja. Op. Cit., 2005, p. 60. Texto do
} 
também fez parte, a seu modo, dos movimentos de modernização nacional do teatro na Irlanda nos anos 1930. Trata-se de uma peça metateatral em um ato cuja estrutura estilizada se utiliza de flashbacks para contextualizar a história em meio à apresentação do background social das personagens, criando tensões formais na lógica burguesa do $\operatorname{drama}^{215}$.

A trama da peça é a seguinte: um jovem dramaturgo, Hugh Riordan, volta a sua pequena cidade natal, Knock, na Irlanda, depois de sucessivos fracassos em Londres, onde fora morar em busca de "material humano" para suas peças. Sua intenção era permanecer na casa dos pais apenas uma noite - para descansar - e partir no dia seguinte. Isso porque não aguentava ficar muito tempo em Knock, cidade que considerava "tediosa demais", "provinciana demais". A idosa Tia Moll, provocativa, acusa a falta de imaginação do sobrinho, ao escutá-lo dizer que em Knock não havia vida, que era uma cidade morta. Ela afirma que enquanto ele insistisse em escrever sobre uma sociedade que não conhecia, sobre a alta sociedade de Londres, iria continuar sem interessar a ninguém, sem capacidade de pagar as próprias contas (as semelhanças com o processo de modernização elitista no Brasil não eram acaso). A indicação da personagem era para que olhasse além da superfície das coisas:

AUNT MOLL - I tell you, me boy, there's comedy and tragedy trailing their skirts through the mud of Church Street if you'd only the eyes to see them. But, oh no, not at all! You must needs write about high London Society, night clubs, cock-tail parties, things you know as much about as - as me boot. And what good does it to you? I don't

\footnotetext{
${ }^{215}$ Ver a teoria sobre a crise do drama em SZONDI, P. Teoria do drama moderno. São Paulo: Cosac \& Naify, 2001.
} 
suppose you've earned a hundred pounds in the seven years you've been in London. ${ }^{216}$

A mãe de Hugh havia organizado uma festinha de recepção para o filho e convidara algumas figuras da cidade: duas irmãs solteironas; o irmão de Hugh com a namorada; uma antiga namorada de Hugh. Lennox Robinson indica na rubrica que a entrada das personagens nessa recepção deve ser meio caótica, todos chegando ao mesmo tempo, com falas que interrompam e se sobreponham umas às outras, indicando o caos inerente à realidade mesma. Os convidados chegam, pois, ao mesmo tempo. Cumprimentam-se uns aos outros de maneira desordenada e mantêm uma conversa agradável. Para Hugh todos parecem “pessoas decentes”, típicas de uma "pacata cidade do interior". Quando entram para a sala de jantar, Hugh permanece na sala de estar com a sua Tia Moll e triunfante rebate a provocação, ao que ela treplica:

HUGH - What's tragic about any of them - except their awful provincialism?

AUNT MOLL - There are three plays for you there, maybe four, if you only had the guts to feel them and the eyes to see them.

HUGH - Play? Ah, go on! I don’t believe you for a minute.

AUNT MOLL (thoughtful, not dictating) - Of course you'd have to select, choose what you'd take and what you'd leave aside. Didn't someone say that genius was the art of selection? And you're no genius. You'd have to - sort of shape your material, just a little, a very

\footnotetext{
${ }^{216}$ ROBINSON, L. Church Street. In: CANFIELD, C. (Org.). Plays of Changing Ireland. New York: The Macmillan Company, 1936, p. 112. TIA MOLL - Eu te digo meu garoto, há comédia e tragédia arrastando suas saias pela lama da Rua da Igreja se você tivesse olhos para enxergá-las. Mas, oh, não, de jeito nenhum! Você precisa escrever sobre a alta sociedade de Londres, sobre clubes noturnos, coquetéis, coisas que você conhece tão bem como - a minha bota. E o que isso lhe traz de bom? Eu não imagino que você tenha conseguido receber ao menos 100 libras nos sete anos que você esteve em Londres. (tradução nossa)
} 
little would be enough. Maybe you couldn't - maybe no dramatist could make that company inside into a play. Maybe it's only through the cinema you could catch it all, all the different stories, interlocking, moving away from each other, moving back to each other again ${ }^{217}$

Sua Tia Moll, figura popular, ensina ao intelectualizado sobrinho os procedimentos de criação dramatúrgica a partir de uma realidade total. Bastaria que soubesse selecionar aspectos da realidade e lhe dar uma forma. Ela lhe abre os olhos para que perceba que por detrás das aparências há vida naquelas pessoas, há tragédia e comédia, "mais tragédia do que comédia, infelizmente". Diante da descrença do sobrinho, ela faz especulações sobre a vida de cada um dos convidados, procurando desvelar conflitos, como o das duas velhas irmãs de quem desconfiava passarem fome, sendo a única coisa que lhes restava era a propriedade de uma casa. O responsável pela condição precária em que elas se encontravam seria o pai de Hugh, que cuidava do dinheiro delas e o teria perdido em suas jogatinas e bebedeiras. Um a um, os personagens vão sendo revelados em suas tristes e intrigantes histórias. Tia Moll desafia o sobrinho a usar todo aquele material humano em suas peças, ao invés de escrever sobre coisas que não importavam ou distantes demais de si. O escritor, por sua vez, começava a perceber que a tia tem razão. Aceita o desafio e em seguida apaga as luzes daquilo que, de repente, se torna um palco. A sala se converte num espaço cênico. Ele conduz a tia para a outra extremidade e sentam-se:

\footnotetext{
${ }^{217}$ Id. Ibid., p. 120. HUGH - O que há de trágico em qualquer um deles - exceto talvez um terrível provincianismo? /TIA MOLL - Há três peças pra você aí, talvez quatro, se você apenas tivesse estômago pra percebê-las e olhos para vê-las. / HUGH - Peças? Ah, fala sério. Eu não acredito em você nem por um segundo./ TIA MOLL (pensativa, não autoritária) - Claro que você teria de selecionar, escolher o que você pegaria e o que você deixaria de lado. Alguém não disse que o gênio estava na arte de selecionar? E você não é um gênio. Você teria que - de algum jeito moldar seu material, só um pouco, um pouco só seria o suficiente. Talvez você não conseguisse - talvez nenhum dramaturgo conseguisse fazer esse empreendimento numa peça. Talvez seja só pelo cinema que você consiga captar tudo, todas diversas histórias, encavalando elas, separando umas das outras, aproximando de novo umas das outras (tradução nossa).
} 
HUGH - You're right, you're right, there's a play here somewhere. I don't quite know where, I don't quite know with whom, I'll have to fish around, try here and there, get them back, not really back, I only mean back in my mind - and in yours, Aunt Moll, for you must help me. But I don't want everyone together, just two or three at a time... I think I'm beginning to see it now... those starving old women... [...] how frightful... [...] But it's inevitable - or is it? Is it all in my own mind or must it - must it happen? Am I shaping events or are they shaping me? [...]

AUNT MOLL - Use your imagination, Hugh. HUGH - I'll try to. ${ }^{218}$

Ele diz à tia que irá evocá-la quando precisar dela para a "representação", e ele próprio será evocado também. A peça então se torna metateatral. O cenário é modificado e substituído por outro similar, mas com um grande banco onde todos os personagens estão sentados, imóveis. A indicação da rubrica é que é possível vê-los nessa posição, como "manequins". Em seguida, Hugh coloca em andamento uma representação da festa de recepção do início, agora sob uma nova perspectiva, em que ele fará com que as personagens manifestem aspectos de seu caráter e sua condição social. Os personagens chegam a casa ordenadamente, um a um. Aquilo que na primeira parte intui-se de maneira incerta, é sublinhado, as circunstâncias são melhores definidas,

\footnotetext{
${ }^{218}$ Id. Ibid., p. 125. HUGH - Você está certa, você está certa, tem uma peça aqui em algum lugar. Eu não sei bem onde, eu não sei bem com quem, eu vou ter que "pescar" por aí, tentar uma coisa aqui, outra ali, trazê-los de volta, não de volta de verdade, eu quero dizer na minha mente - e na sua, Tia Moll, porque você precisa me ajudar. Mas eu não quero todos juntos, apenas dois ou três de cada vez... Eu estou começando a enxergar agora... aquelas velhas famintas... [...] que assustador... [...] mas é inevitável - ou será mesmo? Está tudo na minha própria cabeça ou precisa - precisa mesmo acontecer? Eu estou moldando os eventos ou os eventos estão moldando a mim?/ TIA MOLL - Use a sua imaginação, Hugh. /HUGH - Eu vou tentar.
} 
as falas não se sobrepõem umas às outras. Além disso, os diálogos aparecem entrecortados com cenas em outro tempo espaço, que cumprem a função de comentar e apresentar diversos pontos de vista da situação. Isto ocorre com todos os personagens. Assim, há cenas na casa das irmãs que passam fome e que precisam cortar lenha para acender uma lareira em casa, uma vez que não tem dinheiro para pagar a conta de luz nessa cena Sarah, umas das irmãs, confessa ter roubado alguns salgadinhos do jantar visto há pouco, para comerem depois. Em outro flashback, o pai chega bêbado e confessa ter perdido no jogo o dinheiro das senhoras. Há cena em um trem, em uma casa de aborto etc.

Todas essas circunstâncias criam aberturas narrativas no palco e ajudam a construir uma visão do todo daquelas pessoas, do tipo de sociedade em que estão inseridas. Quando os convidados aparecem novamente na festa na casa dos pais de Hugh, percebe-se a "lama" na qual estão metidos. Mesmo o dramaturgo Hugh é revelado e exposto por esta mesma estrutura. Ao fim da peça dentro da peça, Tia Moll está sensibilizada e comovida com as histórias criadas diante de si. Sente horror ao vislumbrar a possibilidade de que as histórias trágicas sejam realmente a verdade escondida daquelas pessoas, com tanta miséria, moralismos e solidão. Hugh para provar que não passava de ficção diz à tia que irá pedir para revistar a bolsa de Sarah Pettigrew, umas das irmãs, e que não havendo nenhum salgadinho roubado tudo estaria esclarecido, a ficção não passaria de ficção.

O jantar termina e os convidados saem para sala de estar. Na sequência, ficção e realidade são misturadas: convidados transformaram-se pelas revelações do plano metateatral. A festa tem continuidade, mas os diálogos entre as personagens, com duas ou três pessoas de cada vez, apresentam seu lado obscuro. E os momentos subsequentes da festa são como que uma nova versão "real" do que foi indicado na representação. 
Sarah Pettigrew recusa-se, humilhada e ofendida, a abrir sua bolsa para mostrar o que havia dentro. Tia Moll torna-se cada vez mais arrasada com o que emergiu pelas lentes da arte. E assim termina A Rua da Igreja, com esta impressão de que arte e realidade gravitam uma em torno da outra e de que a matéria da arte deve ser a realidade viva, de uma perspectiva social, mas também que uma nova forma de olhar produz o real ${ }^{219}$.

\section{Tensão formal}

Em Church Street, além da evidente questão entre teatro e vida expondo o movimento estético que transforma a realidade em arte (e uma curiosa relação intrincada entre ficção e realidade), é possível vislumbrar uma chamada ao particular, que em alguma medida sugere uma angulação nacional, como fica sugerida na oposição entre um imaginário da Inglaterra e outro da Irlanda.

A peça organiza-se como uma dramaturgia em construção: a matéria do teatro está lá fora e é preciso olhar para além das aparências. Ainda que sua posição esteja mais nos temas do que na forma, para Lennox Robinson, o procedimento criativo envolveria "selecionar um aspecto da realidade, organizar o material e estilizá-lo"220 . O iniciante, querendo apreender o mundo, estaria na posição de Hugh, precisaria testar várias vezes, experimentar aqui e ali até encontrar a medida da forma, além de, fundamentalmente, desfazer os mitos sobre os grandes temas e perceber a pulsação universal no ambiente particular. No fim, a própria realidade seria revelada de uma forma nova e profunda. Isso é um exemplo do que Ruggero Jacobbi entendia como

\footnotetext{
${ }^{219}$ Ainda sobre a peça e o teatro de Lennox Robinson ver: MÂNFIO, G. B. G. Tradição e Inovação: Elementos da poética do teatro em Lennox Robinson. Dissertação (mestrado em Letras), Faculdade de Filosofia, Letras e Ciências Humanas, Universidade de São Paulo, São Paulo, 1996.

${ }^{220}$ ROBINSON, L. Apud MÂNFIO, G. B. G. Op. Cit. p. 111. (Trecho do texto Towards an appreciation of the theater, de Lennox Robinson)
} 
função do teatro: sua contribuição social seria a de "ser um espelho fiel e honesto da realidade humana"221.

Essa ideia condiz com o formato em um ato da peça, que exige um nível de síntese e condensação, próximo ao de um retrato. Como um flagrante de uma realidade, de uma ideia. Por outro lado, ao fazer uso de flashback e outras relações temporais e espaciais, identificam-se, na peça, expedientes narrativos, que distanciam o sujeito daquilo que é narrado. As personagens não são plenamente autodeterminadas, conscientes de si, como no drama, e não é a ação delas que modifica a situação inicial $^{222}$.

A Rua da Igreja introduz a figura do diretor de cena, que manipula as situações e as personagens, criando uma função épica, ou narrativa na estrutura da peça. Antecipa o recurso adotado e consagrado alguns anos depois, em 1938, por Thornton Wilder, em Nossa cidade. A peça americana trata dos antecedentes da primeira guerra mundial, em uma pequena e fictícia cidade do interior. Em abril de 1952 foi encenada no Teatro Leopoldo Fróes, pelo Grupo Teatral Politécnico com direção de cena de Osmar Cruz e produção de Ruggero Jacobbi. Assim como em A Rua da Igreja, Nossa cidade procura, a partir do dia a dia de pessoas comuns, extrair um retrato de uma sociedade. $\mathrm{O}$ argumento de Peter Szondi sobre Nossa cidade serve para tratar do narrador-diretor de $A$ Rua da Igreja:

É o diretor de cena quem está consciente de que eles são personagens, ou seja, a relação sujeito-objeto representa uma relação exterior aos personagens: precisamente a relação épica entre o narrador e seu objeto. [...] No lugar da ação dramática entra a narrativa cênica, cuja

\footnotetext{
${ }^{221}$ JACOBBI, Ruggero. Dinheiro é dinheiro, Última Hora, São Paulo, 24.03.1952. In: Op. Cit., 2005 , p. 9.

${ }^{222}$ SZONDI, P. Op. Cit., 2001, p. 110.
} 
ordem é definida pelo diretor de cena. As diversas partes não engendram umas às outras, como no drama, mas são conjugadas pelo eu-épico e vinculadas em uma totalidade, segundo um plano que vai além do acontecimento particular e toma um sentido universal ${ }^{223}$.

Os flashbacks e os momentos da vida cotidiana - em A Rua da Igreja acontecem numa ordenação não evolutiva, sem que uma ação seja a consequência direta da seguinte, pois a organização de uma totalidade da realidade ficcional está subordinada à uma ação externa ao drama, à ação do narrador/diretor de cena, Hugh. Ele, por outro lado, está dentro da estrutura dramática. As pessoas, ao menos as observadas pelo dramaturgo interno, passam a ser vistas como parte de um todo, de uma mentalidade própria de uma época e lugar. São questionadas a ideologia e a moral das instituições da sociedade civil. O diálogo intersubjetivo não serve, internamente, para desencadear a ação pelo conflito, pelo contrário, as conversas demonstram o lado de aparências, a ponta do iceberg. Para desvelar o restante seria necessário o uso de expedientes não dramáticos, olhar para o passado.

O recurso metateatral, que cria um quadro épico interno ao ato dramático, remete também à obra de Pirandello, como apontado por Jacobbi em sua crítica. O dramaturgo italiano figura entre os preferidos de Ruggero e também de Lennox Robinson. Seis personagens a procura de um autor estreou no TBC, com direção de Adolfo Celi, em 1951. O texto de Pirandello seria, na visão de Peter Szondi, “uma auto-representação da história do drama" 224 .

Assim como Seis personagens, escrita em 1921 - A Rua da Igreja, de 1934, não rompe completamente com a estrutura dramática na medida em que a moldura externa

\footnotetext{
${ }^{223}$ Id. Ibid., p. 158.

${ }^{224}$ Id. Ibid., p. 151.
} 
se vincula ao desenvolvimento da consciência do jovem dramaturgo da ficção. A dinâmica da ação intersubjetiva não é rompida na estrutura. Nos termos de Szondi, na evolução para o épico, a peça de Pirandello estaria no plano intermediário, pois a relação dramática existe entre as personagens, mas essa ação não está em unidade com a ação real. De acordo com Peter Szondi:

\begin{abstract}
A temática se divide em duas camadas: a camada dramática [...], que no entanto já não é mais capaz de constituir uma forma; e uma segunda, épica, que responde àquela tarefa em sua relação com a primeira $[\ldots]^{225}$
\end{abstract}

A temática de A Rua da Igreja também "se divide em duas camadas": a primeira com o plano da realidade, que seria a dramática; a segunda seria a do diretor teatralizando a situação dramática da primeira parte, criando um plano épico em cena ${ }^{226}$.

De um ponto de vista estilístico, A Rua da igreja também dialoga com os pressupostos do realismo crítico. Nos anos de 1950, os criadores da revista Théâtre Populaire, Bernard Dort e Roland Barthes, defenderam a ideia de um "realismo épico" e assim marcam uma fronteira com o "realismo socialista" então em voga, que pretendia ser a reprodução do real. O realismo passaria a ser entendido como um lugar onde se fazem experiências do real, a partir do real, como conta Jean-Pierre Sarrazac:

O teatro realista deixa de ser considerado uma esponja do real, para ser visto sobretudo como uma espécie de lugar in vitro: um espaço

\footnotetext{
${ }^{225}$ Id. Ibid., p. 151.

${ }^{226}$ Lennox Robinson (1886 -1958) era identificado com a escola realista na Irlanda, mas tinha grande interesse em formas não dramáticas; havia introduzido, por exemplo, uma cena cômica de marionetes na peça Ever the Twin; e uma situação cômica absurda na farsa Is life worth living? (Cf. CANFIELD, Curtis. Plays of Changing Ireland. New York: The Macmillan Company, 1936, p. 103).
} 
vazio onde se fazem experiências sobre o real, usando a teatralidade como único protocolo. ${ }^{227}$

Esse lugar "in vitro" é experimentado formalmente em A Rua da Igreja, com a realidade sendo observada a partir de expedientes teatrais. Aquilo que é "destacado", o real, em cena é “teatralizado" para observação.

É bastante simbólico que essa tenha sido a peça escolhida por Ruggero Jacobbi para a estreia de um grupo de teatro amador, com jovens sem experiência com teatro. A escolha pode ser lida, de imediato, como um conjunto de conselhos a jovens artistas, e mesmo não sendo plenamente paradigmática do projeto de modernização que Jacobbi encampou, ela toca em alguns pontos importantes dele, sugerindo um modelo de epicização relativa do drama que poderia inspirar a criação de uma dramaturgia nacional com temática social. A peça, a seu modo, aponta para o debate da dialética do universal e do particular, isto é, quanto maior a atenção para as questões locais mais a chance de encontrar o universal sobre relações sociais repostas. Almeja algo daquele “universalismo popular" de que falava Gramsci ${ }^{228}$.

Vislumbra-se assim o tipo de interesse que Jacobbi poderia supor na realização de uma peça como Church Street por amadores brasileiros, no sentido de uma formação de caráter popular.

Em sua crítica sobre a estreia, Ruggero Jacobbi faz referência ao escritor Lennox Robinson e sua participação no processo de modernização do teatro na Irlanda através do Abbey Theatre (1904), que desde 1909 tinha o dramaturgo como diretor ${ }^{229}$. O

\footnotetext{
${ }^{227}$ SARRAZAC, Jean-Pierre. A invenção da teatralidade. Sala Preta, Brasil, v. 13, n. 1, p. 56-70, jun. 2013, p. 59

${ }^{228}$ GRAMSCI, A. Literatura e vida nacional. Rio de Janeiro: Editora Civilização brasileira, 1968, p. 79.

${ }^{229}$ Em 1899 nasceu na Irlanda o Teatro Literário Irlandês, como resposta ao comercialismo e em busca de pesquisas de novas formas de expressão - seguia o modelo dos teatros livres europeus originados com Antoine em 1887 em Paris. O Teatro Literário Irlandês foi fundado em Dublin, por W.B Yeats, Lady Gregory, Edward Martin e George Moore. Uma característica desse grupo era seu cunho nacionalista. O
} 
interesse pedagógico de Ruggero a respeito desse texto é evidente. Via ali um exemplo de texto moderno simples que seria capaz de sugerir um tensionamento da forma dramática e um deslocamento das convenções do naturalismo grosseiro.

Apesar disso tudo, nenhum desses aspectos do texto foi sublinhado por Guarnieri nas entrevistas sobre o período. Aracy Amaral ou Regina Helena de Paiva, atrizes da montagem do TPE, também não demonstraram ter muita lembrança da peça em entrevistas realizadas para esta pesquisa. $\mathrm{O}$ que restou na memória, para além de qualquer influência crítica ou estética, foi mais o contexto do trabalho teatral nos ensaios e o "racha" no grupo. Afinal, A Rua da igreja foi apresentada uma única vez, pois Guarnieri e Vianinha decidiram suspendê-la, o que deflagrou uma cisão ideológica no grupo.

\section{Estreia e interrupção de A Rua da Igreja}

O texto irlandês foi sugerido aos jovens pelo próprio Ruggero, numa tradução feita por ele e sua companheira e colaboradora Carla Civelli ${ }^{230}$. Segundo depoimentos das atrizes da montagem, Regina Helena de Paiva e Aracy Amaral, Ruggero Jacobbi acompanhava de perto os ensaios e a direção ${ }^{231}$, que ficou a cargo da estreante Sofia Rosenhaus. No jornal Imprensa Popular, do Partido Comunista, há uma nota

clima de tensão entre Inglaterra e Irlanda, que levou à guerra pela independência da Irlanda, entre os anos 1919 e 1921, já há muito podia ser sentido. O Teatro Literário Irlandês procurava incentivar a dramaturgia nacional, com temáticas e encenações nacionais. Precisavam criar os caminhos para uma produção local que até aquele momento fora muito esporádica e rarefeita, devido à colonização inglesa. O Abbey Theatre, a sede desse grupo que até então não tinha lugar para ensaiar, surge em 1904, financiada por Elizabeth Horniman. Lennox Robinson ingressa como diretor nesse teatro no ano de 1909 e sua entrada corresponde a uma nova fase do Abbey Theatre, com o abandono de "temas místicos" e "idealistas (românticos)" e com o interesse crescente por questões políticas e ligadas a realidade material das pessoas. (Cf. MÂNFIO, G. B. G. Op. Cit., 1996, pp. 2-6).

${ }^{230}$ A tradução foi procurada sem sucesso nos arquivos Miroel Silveira, na Hemeroteca Nacional, no Acervo CEDOC da Funarte, no Acervo Paschoal Carlos Magno. Também investigamos nos arquivos pessoais de muitos participantes do período, mas não se tem notícia se há alguma cópia conservada.

${ }^{231}$ Entrevistas realizadas nos dias 13.04.2015 e 28.05.2015, respectivamente. 
comentando sobre a estreia do TPE, em que aparece o nome de Ruggero como supervisor da peça ${ }^{232}$.

O elenco composto para essa primeira montagem era realmente amador, muitos sem nenhuma relação anterior com o teatro. A maioria não estava presente na reunião de fundação do grupo e nem necessariamente partilhava de seus ideais, como dão exemplo os depoimentos de Regina Helena Paiva e Aracy Amaral ${ }^{233}$. Ruggero Jacobbi teria feito audições para o espetáculo, segundo Aracy Amaral, em um apartamento no bairro de Higienópolis, em que pedia para os interessados interpretarem um trecho de falas das personagens da peça. Segundo ela, ali mesmo ele começou a distribuir os papéis.

O elenco como aparece no programa da peça é o seguinte (na ordem em que aparecem): Oduvaldo Viana Filho; Wilma Leite Silva; Aracy Abreu Amaral; João Francisco Guarnieri ${ }^{234}$; Mirna Rojman; Regina Helena de Paiva Ramos; Sophie Rosenhaus; Pedro Paulo de Uzeda Moreira; Renata Roman; Mariuza Viana; Henrique Liberman; Antonio Henrique A. Amaral, Esther Welskop; Diorandy José Vianna. Diretor de cena: Sergio Giuli, Figurinos: Colaboração de Wolfgang Pfeiffer, Maquiagem: Barry. No programa há também um agradecimento especial pela ajuda prestada por Raymundo Duprat ${ }^{235}$.

\footnotetext{
${ }^{232}$ Imprensa Popular, Rio de Janeiro, 12.06.1955. No relatório que Gianfrancesco Guarnieri elaborou para a Fundação Vitae o nome de Ruggero também aparece como "supervisor".

${ }^{233}$ As duas e Antônio Henrique Amaral, por exemplo, haviam feito graduação em jornalismo pela Cásper Líbero. Aracy Amaral e algumas pessoas que estavam na plateia como Aparício Basílio da Silva e Leonor Scarano haviam sido monitores da primeira bienal de artes de São Paulo.

${ }^{234}$ Gianfrancesco Guarnieri, devido a dificuldades que enfrentou por ser de origem italiana, muitas vezes assinava o nome como João Francisco Guarnieri : "Na escola eu enfrentei alguns problemas por ser uma criança italiana, principalmente em função da indecisão do governo do Getúlio Vargas, que não sabia qual lado da guerra ele iria apoiar. Ser italiano causava em mim um certo temor, tanto que, na prova de admissão para o ginásio, eu assinei João Francisco Guarnieri. O diretor me chamou e disse que aquela prova não valia, pois meu nome era Gianfrancesco. Ainda assim, eu usaria o nome de João Francisco em outras ocasiões, talvez para me poupar um pouco. Talvez por isso, no início da minha carreira de ator, alguns jornais chegaram a publicar meu nome como sendo João Francisco". (GUARNIERI, G. Apud ROVERI, S. Gianfrancesco Guarnieri. Um grito solto no ar. São Paulo: Imprensa Oficial, 2004, p. 26)

${ }^{235}$ Alguns desses nomes vieram a ter grande destaque nas artes plásticas, como Aracy Amaral e seu irmão Antônio Henrique Amaral. Regina Helena Paiva tornou-se importante jornalista, Pedro Paulo Uzeda
} 
No dia da estreia, uma segunda feira fria e chuvosa, o pequeno Teatro de Arena estava lotado. No público estavam importantes nomes da cena teatral e cultural da cidade de São Paulo, como Décio de Almeida Prado, Ítalo Rossi (que viria a dirigir um espetáculo do grupo), Sábato Magaldi, Clóvis Garcia, Nilo Prado, Mattos Pacheco, Silveira Sampaio, Oduvaldo Vianna, Deocélia Vianna, entre outros.

A presença de pessoas representativas e influentes do meio teatral, na estreia de um grupo amador, corrobora a impressão de que havia certa atenção diante da criação do TPE. Isso se dava em parte, provavelmente, pelo interesse em torno de Ruggero Jacobbi, em parte pelo fato de a apresentação ter sido na sede do Teatro de Arena, que já se firmava enquanto companhia. De qualquer maneira, a plateia estava cheia não apenas por amigos e familiares do elenco, mas também pela categoria de artistas teatrais, que apoiou em peso a criação do Teatro Paulista do Estudante. E de acordo com um crítico do Estado de São Paulo, havia uma grande parcela de outro público, desabituado ao espetáculo teatral. Não há registros claros de que o Comitê Cultural do PCB esteve presente como representação coletiva, mas a presença observada desse "outro" público poderia se dever a jovens pecebistas integrados à categoria estudantil, como também pela influência de Jacobbi, que participava já havia alguns anos de iniciativas descentralizadas e com algum apelo popular.

Para o crítico do Estadão, a gratuidade do ingresso, cujo gesto ele aplaudia como iniciativa importante para a difusão e desenvolvimento do teatro, explicaria, em parte a casa estar tão cheia. E para ele os "animadores ocultos" dessa empreitada seriam Ruggero Jacobbi e Carla Civelli.

psicanalista, Wilma Leite e Silva criou uma escola de culinária, por exemplo. Aracy Amaral contou que tinha enorme interesse pelo palco, mas boicotava sua vocação e que nunca se esquecerá do teste que fez para Na Rua da Igreja, quando Ruggero lhe chamou em um canto e lhe disse estar impressionado com sua atuação, da mesma forma que havia se impressionado ao ver pela primeira vez Cacilda Becker atuando. 
o teatro de São Paulo fica devendo a eles, ao seu desinteresse e a sua simpatia por tudo quanto é jovem e bem intencionado, mais esta iniciativa, não destituída de valor - valor, por enquanto, é verdade, mais humano do que efetivamente artístico. ${ }^{236}$

Em artigo publicado por outro crítico no Diário de São Paulo, não assinado, o comentário destaca a expectativa positiva em relação ao crescimento do grupo e valoriza a escolha da peça encenada. As dificuldades seriam as encontradas por atores inexperientes, jovens demais para os papéis, ao interpretarem uma peça com uma estrutura como a de A Rua da Igreja. Ainda de acordo com o texto, o temor do público aumentou diante da "breve alocução" de Sofia Rosenhaus, que "pediu, de um modo algo insistente, a complacência do público"237. Mas parece que ao fim, o trabalho dos jovens atores agradou:

Mas para regozijo geral, A Rua da Igreja, do autor irlandês Lennox Robinson, [...] assinalou com relativo êxito a estreia do Teatro Paulista do Estudante, não obstante a direção bastante insegura de Sofia Rosenhaus $^{238}$.

A impressão geral que se observa nas críticas da época era que o TPE levou a peça com simplicidade de recursos. No entanto, espantosamente, Guarnieri e Vianinha, após a estreia, e uma noite inteira de bebedeira, chegaram à conclusão de que não poderiam prosseguir com o espetáculo, que aquela peça, feita para aquele público, não

\footnotetext{
${ }^{236}$ Palcos e Circos Amadores. O Estado de S. Paulo. Domingo, 05 de junho de 1955. Sem assinatura.

${ }^{237}$ Recorte de jornal do arquivo pessoal de Regina Helena de Paiva Ramos. Diário de S. Paulo. Sem data e sem assinatura.

${ }^{238}$ Recorte de jornal do arquivo pessoal de Regina Helena de Paiva Ramos. Diário de S. Paulo. Sem data e sem assinatura.
} 
lhes dizia respeito. Eles acharam que a "estreia não se diferenciava em nada de qualquer outro grupo de teatro amador,"239.

Decidiram que não haveria mais espetáculo na próxima segunda feira - a peça ficaria em cartaz às segundas feiras ${ }^{240}$ - e de fato não houve. Essa postura dos dois não foi consenso entre os atores causando uma fissura que levaria à saída de boa parte do elenco.

Tanto Aracy Amaral quanto Regina Helena de Paiva em entrevista contaram que um motivo de grande discussão no elenco de $A$ Rua da Igreja se referia às ideias de Guarnieri e Vianinha sobre a continuidade do grupo. Antes mesmo de estrearem discutiam sobre como levar a peça para apresentações em países socialistas do leste europeu, para a convenção de Varsóvia que seria realizada pelos aliados à União Soviética naquele ano. E que para essas viagens, e sustentação do grupo, cogitavam arrecadar dinheiro com operários, nas fábricas e sindicatos. A informação de Regina Helena, a despeito de um tom irônico sugerido por suas convicções atuais, indica a questão:

Vianinha e Guarnieri eram do Partidão. Eles queriam que fôssemos representar no Festival de teatro nos países da Cortina de Ferro. Aracy Amaral, a Sophie e eu achávamos que não tínhamos capacidade de apresentar a peça em festivais, estávamos muito crus. E "além do mais", eu perguntei, "com que dinheiro?" E o Vianinha disse assim: "Nos vamos pedir dinheiro na porta de fábrica". E eu: "não vou viajar

\footnotetext{
${ }^{239}$ GUARNIERI, G. Apud KHOURY, S. Atrás da máscara. Rio de Janeiro: Civilização Brasileira, v.1, 1984, p. 25.

${ }^{240}$ Talvez essa ideia de teatro às segundas feiras fosse uma retomada do teatro às segundas feiras que Ruggero fundou no TBC, uma tentativa de lançar novos autores, atores e textos experimentais.
} 
com dinheiro de operário". E eu, Aracy, Sophie, Antônio Henrique e outros saímos ${ }^{241}$.

Regina Helena contou que no período em que participou do Teatro Paulista do Estudante não era "politizada" e que se lembra de discordar da postura política de Vianinha e de Guarnieri. Também lembra que os ensaios eram constantemente interrompidos por discussões de conjuntura e todos opinavam sobre os procedimentos estéticos. Para ela, aquilo era extremamente "amador", muito improvisado. Aparentemente eles estrearam sem nunca ter ensaiado a parte final da peça ${ }^{242}$. E a ela parecia difícil de acreditar que aquele grupo teria alguma continuidade, ou "relevância" no teatro brasileiro:

Os ensaios do Teatro Paulista do Estudante eram de total amadorismo, absoluto amadorismo. Eu achava que ia ser um fracasso. Era muito quebra-pau. Era um amadorismo tão grande, uma precariedade tão grande, que eu fiquei morrendo de medo de me comprometer muito. Eu achava que ia ser um fracasso desgraçado e eu ia dar com a cara no chão. Então eu estava muito preocupada com isso, éramos todos inexperientes. Era de um amadorismo que me preocupava muito. Para se ter uma ideia, o segundo ato nós nunca tínhamos passado inteiro. Passávamos trechos. No ensaio geral só tínhamos feito o primeiro ato. $\mathrm{Eu}$ comecei a ficar apavorada. Eu fui como se vai para guilhotina. E foi um sucesso. ${ }^{243}$

\footnotetext{
${ }^{241}$ Aracy Amaral, no entanto, disse não saber na época que eles pertenciam ao PCB. De resto confirmou a impressão de Regina Helena quanto à questão do financiamento e das constantes discussões internas.

${ }^{242} \mathrm{Na}$ encenação eles transformaram a peça em dois atos, ao invés de um. Na peça escrita há uma clara divisão entre uma primeira parte realista e uma segunda metateatral, apesar de ser um único ato.

${ }^{243}$ Entrevista de Regina Helena à autora dia 13.04.2015.
} 
Note-se aqui que a expressão "amador" assume sentido negativo, indicando algo mal feito, improvisado. Contudo, as lembranças de Regina Helena permitem que se vislumbre um modo de produção efetivamente na contramão ao modelo profissional em curso no Brasil. Os atores discutiam como fazer a peça, os sentidos que dariam para ela, discutiam política durante os ensaios, enfim, intervinham diretamente em aspectos totalizantes da criação. E isso com o olhar presente (e, ao que tudo indica, com anuência) de um encenador profissional estrangeiro muito mais maduro e culto do que eles, que dirigiu importantes montagens no TBC.

A dedicação com que Jacobbi trabalhou em favor de tantos empreendimentos amadores residia justamente na crença de que ali estava uma possibilidade de livre experimentação e investigação social no teatro. $\mathrm{O}$ espetáculo amador arrumadinho não interessava propriamente, mas sim aquele que mergulhava de cabeça em seu projeto, sem medo da tentativa e do erro. Interessava a liberdade experimental do aprendizado coletivo.

Era uma postura, entretanto, que ele parecia carregar para todas as suas encenações, a despeito de serem profissionais ou amadoras. Via o teatro como um lugar em construção, de debate a partir de experiências concretas, o que inclui as da teatralidade. Essa questão aponta para algo presente nas preocupações de Ruggero Jacobbi e também nas dos jovens comunistas: a função social no teatro, a possibilidade de inventar formas de arte capazes de refletir sobre a vida social e mobilizadoras de intervenção de sentido político.

De acordo com Guarnieri, em entrevista de 1997, foi Ruggero quem inaugurou esse tipo de posicionamento político nos debates sobre o processo de modernização, dentro do TBC, indo além das oposições dualistas entre o teatro arcaico e o esteticamente novo: 
Em primeiro lugar, ele admitia que a função do teatro era social. Bom, não parece ter nada demais, mas naquela época tinha tudo demais, porque os outros diretores (do $\mathrm{TBC}$, e fora do $\mathrm{TBC}$ ), não eram preocupados com este aspecto e pensavam que o teatro não tinha função nenhuma fora da função estética. Foi Ruggero que trouxe dentro do TBC esta posição ${ }^{244}$.

Essa forma própria de engajamento custava caro ao italiano. Era frequente que atores e encenadores da época propagassem uma crítica rasteira sobre a atitude de Jacobbi: diziam que ele não tinha um apuro muito grande no acabamento das peças, e que ele era muito mais um intelectual do que um artista diretor. Em alguns momentos, críticos e atores destacaram, na prática do encenador italiano, uma dicotomia entre intenções políticas e estéticas, como se não pudessem andar juntas.

A crítica de Décio de Almeida Prado para a montagem de Mirandolina em 1955 pelo Teatro Popular de Arte (que nessa altura já se chamava Companhia Maria Della Costa), com direção de Jacobbi, é emblemática para que se entenda o tipo de "acusação" que o trabalho de Jacobbi sofria:

Ruggero Jacobbi como crítico e como encenador adota, com frequência, dois critérios diversos de julgamento: o estético e o político (no sentido mais largo e mais nobre do termo, sem nenhuma sombra de sectarismo). Ora, não se pode observar um objeto de dois ângulos ao mesmo tempo. Enquanto ele não resolver esta contradição, dando preeminência a um desses pontos de vista, estabelecendo uma

\footnotetext{
${ }^{244}$ Entrevista inédita de Guarnieri concedida à Alessandra Vannucci, São Paulo 22.06.1997
} 
hierarquia de valores, sem saber a quem servir primeiro lugar, se ao teatro ou se à sua concepção de arte interessada ${ }^{245}$.

Para o diretor italiano, no entanto, a peça representava a luta de classes nas circunstâncias da revolução francesa, em que uma aristocracia estabelecida e decadente era enfrentada por uma burguesia em ascensão, prestes a se estabelecer. Era precisamente essa questão política que convertia o teatro de Goldoni numa arte "maravilhosamente impura", isto é, "cheia de fermentos morais, de implicações objetivas, [...] de uma obsessão do real que não quer saber de transfigurações”. Jacobbi, no texto sobre a Atualidade de Goldoni, conclui:

Transfiguradora é a forma, como sempre, é a forma: mas é a forma de um conteúdo, não é uma veste: é o próprio corpo ${ }^{246}$.

Parte da acusação de precariedade artística ou de intelectualismo excessivo devem ser creditadas, portanto, a uma incompreensão da dimensão política da visão de arte de Ruggero que contaminava seu modo de trabalho teatral. Há relatos que indicam que, na direção, Ruggero buscava deixar muito espaço de criação e experimentação para os atores. Pensava sempre no teatro de equipe. E o teatro amador seria o espaço ideal para desenvolver essa característica de construção conjunta, sem estrelismo. Sérgio de Carvalho, a respeito dessa fama que Ruggero Jacobbi recebeu de ser um diretor limitado, fez a seguinte reflexão sugerindo uma inclinação contrária a qualquer lógica do efeito mercantil:

\footnotetext{
${ }^{245}$ PRADO, D. A. Mirandolina. O Estado de S. Paulo, Coluna Palcos e Circos, 17.7.1955.

${ }^{246}$ JACOBBI, R. Atualidade de Goldoni. $O$ Estado de S. Paulo. Suplemento Literário. Ano 2, no 1, 21 dez. 1957 , p. 5.
} 
Tenho cá pra mim que o mito de que Ruggero Jacobbi não era um bom diretor teatral, considerado "preguiçoso na direção dos atores" [...] reflete uma incompreensão sobre seu curioso experimentalismo. Acredito que ele detestava uniformizações de qualquer tipo, realistas ou estilizadas. Considerava um indício de tacanhice o nivelamento formal do elenco, a sujeição da variedade humana do grupo a uma estratégia de efeitos teatrais ${ }^{247}$.

O que Regina Helena considerava como "amadorismo", então, estava no fato de que os atores, junto com a direção, eram estimulados a constantes debates sobre os sentidos da peça, protótipo de um avançado trabalho de grupo, avesso a especialização das funções. Obviamente uma sala de ensaio não é uma assembleia em que os problemas são de ordem discursiva, e podem ter havido excessos imagináveis num grupo de militância estudantil comunista, mas o fato é que esse modo de trabalho coletivizado e livre seria importante para os avanços que o Teatro de Arena veio a produzir nos anos seguintes.

No TPE, ainda, os atores eram obrigados a cuidar dos figurinos e cenários, compondo as personagens a partir do próprio guarda-roupa, como indicam os depoimentos de Regina Helena de Paiva e Aracy Amaral. E quando se juntaram ao Arena, muitos deles experimentaram, além da atuação, a dramaturgia e a pedagogia, o trabalho em mais de uma frente, mantendo "acesa a chama do espírito amador"

\footnotetext{
${ }^{247}$ CARVALHO, S. Posfácio - Ruggero Jacobbi. In: JACOBBI, R. Teatro no Brasil. São Paulo: Editora Perspectiva, 2012, p. 202.

${ }^{248}$ JACOBBI, R. A hora dos amadores, Folha da Noite, 26.11.1952. In: Crítica da razão teatral. São Paulo: Perspectiva, 2005, p. 14. No mesmo texto ele diz ainda: "A outra função [dos amadores] é manter viva a chama do teatro de vanguarda - não daquela vanguarda que é pura extravagância ou repetição de fórmulas ainda vivas na memória dos esnobes, mas sim daquele espírito de renovação, ousado e paciente ao mesmo tempo, do qual quase sempre nascem as grandes e progressivas descobertas da arte cênica"
} 
Contudo, por razões variadas e discutíveis, a montagem de A Rua da Igreja não correspondeu às expectativas dos jovens comunistas. Tinham a impressão de que a peça de Lennox não tinha "nada a ver com o Brasil",249, não era isso que queriam fazer. Não achavam que essa peça pudesse interessar ao público politizado com o qual pretendiam dialogar e ao que tudo indica procuravam uma peça de temática nacional, sem maior percepção do sentido modelador que o texto de Lennox pudesse ter para um projeto nacional popular.

Guarnieri, ao falar dessa montagem, costumava destacar o fato dela ser irlandesa, estrangeira, mantendo pouca conexão com a realidade brasileira. Ele, inclusive, comparou essa montagem com a de Ratos e Homens, de Steinbeck, feita no Teatro de Arena 1956, com direção de Augusto Boal, que ao menos permitia aproximações de sentido social, ligadas ao universo do trabalho:

[o TPE] começou com uma peça irlandesa, do Lennox Robinson, que foi feita realmente enquanto irlandesa, que para nós não diz nada, chata. Agora, o Steinbeck não. Nós começamos vivendo o texto do ponto de vista de uma relação miserável entre os trabalhadores, um comendo o pão do outro, e desse ponto de vista daria para adaptar a nossa realidade do campo, sem mexer uma vírgula do texto, porque não precisava. Aquela realidade era nossa. A gente discutia aquilo como fosse uma situação real, porque podia perfeitamente acontecer aqui ${ }^{250}$.

Era como se as circunstâncias de A Rua da Igreja fossem menos adaptáveis para o Brasil do que as de Ratos e Homens. O estranho disso é que A Rua da Igreja parecia

\footnotetext{
${ }^{249}$ Entrevista inédita de Guarnieri concedia a Alessandra Vannucci, São Paulo, 22.06.1997.

${ }^{250}$ Entrevista inédita de Guarnieri concedia a Alessandra Vannucci, São Paulo, 22.06.1997.
} 
um bom material para uma reflexão crítica sobre os problemas da atualização cultural e da modernização brasileira, se opondo ao cosmopolitismo característico de nossas tradições de renovação conservadora. O tema, em alguns aspectos, se precipitava em forma, e poderia servir como modelo para outro tipo de dramaturgia, para além do drama social. Mas, de alguma maneira, não encontrou ressonância nos primeiros anseios dos tepecistas.

As razões da recusa não são evidentes, uma vez que os próprios desejos dos jovens ainda estavam algo disformes. Mas algumas questões podem ter contribuído, como a própria expectativa formal. É conhecido, por exemplo, o desinteresse daquela nova geração politizada pelo teatro de Pirandello ${ }^{251}$. Ruggero Jacobbi empenhou-se em destacar o conteúdo social nas obras do dramaturgo italiano, sem muito sucesso. Talvez o formato antidramático, metateatral (mas não explicitamente popular) causasse algum afastamento dos jovens, que taxavam aquelas peças de "literatura burguesa"252.

É possível que por trás dessa negação estivesse latente a vontade de um teatro nacional realista e as expectativas estéticas geradas pelo Partido, de um drama social, alimentadas pelo anseio da transposição de um realismo positivo para o mundo do teatro. Até 1956, qualquer questão estética, para o $\mathrm{PCB}$, ainda tinha que dialogar muito diretamente com os padrões do Realismo Socialista, em consonância com as tendências soviéticas e com os princípios da Frente Popular.

\footnotetext{
${ }^{251}$ Pirandello era associado pelos comunistas do TPE ao repertório estrangeiro do TBC, incorporado nos primeiros anos pelo Teatro de Arena e superado pelo processo de politização do mesmo, a partir da entrada do TPE. Em entrevista a Alessandra Vannucci, Guarnieri diz: "o Arena foi fundado em 52 pela primeira turma de formandos da EAD. Eram todos jovens. Não tinham teatro. Ficaram três anos batalhando por aí, trabalhando em casas de familha, no Museo do Arte Moderna, e fazendo um repertório muito parecido ao TBC, faziam Pirandello. E nós, do TPE, a mesma coisa: nós estreiamos no Arena com Lennox Robinson. Lennox Robinson não tinha nada a ver com a gente, mas nós não tinhamos idéia de um outro repertório". Vianinha, no texto Do Arena ao CPC falando sobre o estágio de "superação" que o Arena representou com relação ao TBC diz o seguinte: "Da tortura mental de Pirandello à procura de "porquês", para a palavra direta e evidente de Guarnieri a expor os "como". Para o Arena a cabeça do público não era mais bazar de produtos culturais. Para o Arena, a cultura não era feira livre, bazar, mercadinho" (VIANNA Filho, Oduvaldo. Do Arena ao CPC. In: política). São Paulo: Brasiliense, 1983, p. 91).

${ }^{252}$ Entrevista inédita de Guarnieri concedia a Alessandra Vannucci, São Paulo, 22.06.1997.
} 
Apesar da influência determinante do encenador italiano na constituição de um grupo como o TPE, e mesmo de sua atenção ao sentido de formação teatral dado pela escolha (e pouca gente influenciou tanto o teatro brasileiro do tempo, como ele) havia alguma dissonância com os desejos ainda pouco formulados daquele grupo, que podiam se ligar a questões produtivas (vínculos com movimentos estudantis de orientação comunista), temáticas (interesse em questões ligadas ao trabalho no Brasil) e formais (gosto pelas formas mais tradicionais do drama social com personagens positivas).

Tudo indica, assim, que entre os jovens comunistas do TPE se formava uma expectativa por um drama social brasileiro a ser escrito e encenado. Não é por acaso que, após o contato com Augusto Boal, que lhe apresentou outras ferramentas técnicas capazes de viabilizar essa tendência em padrões menos convencionais, Guarnieri tenha começado, já em 1956, menos de um ano depois da estreia do TPE, a escrever Eles não usam black-tie. ${ }^{253}$

Como veremos adiante, Black-tie reunia várias das características que de algum modo estavam sendo perseguidas pelos jovens comunistas, como a temática brasileira, $o$ protagonismo de representantes do povo em cena, ao menos um lutador do povo consciente da situação política, e uma estética que assumia também influências do movimento do neorrealismo no cinema ${ }^{254}$.

$\mathrm{Na}$ recusa aos padrões mais abertos sugeridos por Jacobbi (que, tudo indica, procurava elaborações mais críticas em relação aos padrões do drama social de tendência naturalista), existe entretanto uma intuição temática importante, que mostra

\footnotetext{
${ }^{253}$ GUARNIERI, Gianfrancesco APUD. ROVERI, Sérgio. Gianfrancesco Guarnieri. Um grito solto no ar. São Paulo: Imprensa Oficial, 2004. P.75

${ }^{254}$ A influência do neorrealismo italiano parece ter sido bastante importante para os fundadores do TPE que viriam depois integrar o Teatro de Arena. Aos jovens comunistas, a influência de um drama poético que abordava temática social, que mostrava pessoas reais falando de maneira natural, vivendo dramas do cotidiano, foi decisiva. Guarnieri em diversas entrevistas afirma sobre a importância que teve o cinema neorrealista italiano da década de 1940 no trabalho dele como ator e dramaturgo. Flávio Migliaccio, por exemplo, em entrevista para essa pesquisa comentou a admiração e importância que o neorrealismo teve na sua vida profissional: "Eu gostava era do Totó, o neorrealismo italiano, do Aldo Fabrizi. Não sabia quem era, mas gostava daquilo. Daquele tipo de interpretação".
} 
um acerto intuitivo dos jovens militantes: aquela geração queria menos discutir o papel do intelectual e suas questões formais e mais diretamente se aproximar do mundo dos trabalhadores, compreender suas questões agudas no país atual diante do momento histórico, mesmo que o preço a pagar fosse uma aproximação ingênua do ponto de vista da representação. A hora pedia.

Depois do episódio da suspensão da peça, Ruggero Jacobbi manteve contato menos frequente com o grupo, passando a orientá-lo à distância. Foi dirigir Mirandolina para o Teatro Maria Della Costa (antigo Teatro Popular de Arte) em 1955. No final desse ano, fez sua única viagem para a Europa no período em que viveu no Brasil, para cobrir a Bienal de Veneza para a Folha de São Paulo - viagem que realizou junto com Paschoal Carlos Magno. Foi nessa ocasião que reviu os amigos do Piccolo e entrevistou Brecht. Antes de voltar ao Brasil foi a Portugal para assinar o manifesto da Conferência da Paz, contra a ditadura de Salazar. De volta a São Paulo foi preso e interrogado pelo DOPS por quatro dias. Havia uma compreensão por parte do governo brasileiro de que as "campanhas pela paz" eram ações de $\operatorname{comunistas}^{255}$. Diante de sua prisão e da iminente expulsão do país, dezenas de artistas, Cacilda Becker à frente, fizeram manifesto de apoio a Ruggero Jacobbi. O caso acabou sendo arquivado por Juscelino Kubitschek. Segundo Alessandra Vannucci, é possível que esse fato tenha influenciado na decisão de Jacobbi de se mudar para Porto Alegre - onde fundou o curso de Artes Cênicas na Universidade Federal do Rio Grande do Sul, em 1958 - e de finalmente, em 1960, resolver voltar definitivamente para a Itália ${ }^{256}$.

\footnotetext{
${ }^{255} \mathrm{E}$ de fato eram os comunistas que estavam à frente dos movimentos pela paz, durante a Guerra Fria Foram feitos, nesse sentido, alguns congressos e conferências internacionais de intelectuais e comunistas pela paz, desde fins da década de 40 (Cf. RIBEIRO, J. F. Os "inimigos da paz": estado, imprensa e a repressão ao movimento dos "partidários da paz" no Brasil (1950-1956). Saculum - Revista de História. João Pessoa, jul.-dez. 2007).

${ }^{256}$ Id. Ibid., p. 202.
} 
De uma forma ou de outra, A Rua da Igreja não teve continuidade. Ruggero Jacobbi insistiu, todavia, para que o coletivo de artistas seguisse unido, para que não desistissem do TPE. Sabia que apesar das diferenças, existia ali uma grande força mobilizada em direção à construção de uma via popular e engajada para o teatro moderno brasileiro. 


\title{
Capitulo 5
}

\section{ESBOÇO DE UM PROGRAMA NACIONAL POPULAR PARA O TEATRO}

\author{
AMADOR
}

Após a suspensão de A Rua da Igreja, e a cisão decorrente no grupo, os remanescentes procuraram realizar, de abril a novembro de 1955, ações de militância no ambiente do teatro amador. Guarnieri relata a cisão em termos vagos, como se fosse uma questão de tendência ideológica:

\begin{abstract}
Aí a turma mais da direita foi embora e a turma que ficou deu uma puxada mais para a esquerda, ficou com o teatro e deu uma radicalizada. Mas ficou difícil a gente conseguir fazer o que queria ${ }^{257}$.
\end{abstract}

O fato é que nesse período, os membros remanescentes do TPE (Vera Gertel, Vianinha, Guarnieri, Uzeda, Mariúsa, entre outros) reafirmaram e divulgaram em dois números da recém-lançada Revista do Teatro Amador ${ }^{258}$ as principais teses do projeto do grupo e também estabeleceram um programa de ação para o ano seguinte (que ocorre parcialmente, pois antes se integram ao elenco profissional do Teatro de Arena ${ }^{259}$.

\footnotetext{
${ }^{257}$ GUARNIERI, G. In: KHOURY, S. Atrás da máscara. Rio de Janeiro: Civilização Brasileira, 1984. Volume 1. P. 25.

${ }^{258}$ A Federação Paulista de Teatro Amador criou em conjunto com o Clube do Teatro a Revista de Teatro Amador, em 1954. Em 1958 Osmar Cruz assume a direção da Federação Paulista de Teatro Amador e transforma a Revista do Teatro Amador em Revista de Estudos Teatrais, marcando uma orientação menos voltada as questões do amadorismo.

${ }^{259}$ TEATRO PAULISTA DO ESTUDANTE. O teatro amador em defesa de nossas tradições culturais Tese apresentada pelo Teatro Paulista do Estudante no II Congresso Paulista do Teatro Amador, em setembro de 1955. Revista do Teatro Amador, Ano 1, nº 6, jan. 1956 (Ver anexo). Há também a entrevista que os editores da Revista do Teatro Amador realizam com o Teatro Paulista do Estudante, em que eles revelam um programa nacional e popular que pretendiam desenvolver com o grupo. (Entrevista com TPE. Revista do Teatro Amador, Ano 1, $\mathrm{n}^{\circ}$ 5, dez. 1955).
} 
As teses ressaltavam a necessidade de se reorientar os rumos da cultura para que ela desse voz aos anseios do povo brasileiro, uma vez que a arte não viveria “independente dos problemas políticos e econômicos" $" 260$.

O caminho para esse novo teatro não era claro aos jovens artistas e a precária condição financeira não ajudava. Faziam de tudo um pouco na tentativa de viabilizar as ações do grupo ${ }^{261}$. Era necessário que se articulassem em torno de projetos que pudessem dar apoio ou mesmo mínimas condições para a produção. A relação com o grupo profissional do Arena nasce dessa necessidade. Ao mesmo tempo, aproximam-se do movimento de teatro amador de São Paulo e da Federação Paulista de Teatro Amador (FPAT) com propostas para subsídios estatais.

A FPAT foi fundada no dia 23 de abril de $1952^{262}$. J. E. Coelho Neto foi nomeado presidente, Osmar Rodrigues Cruz, tesoureiro e Clóvis Garcia, diretor administrativo. Todos eles eram atuantes na cena teatral amadora, como atores, diretores e críticos. A finalidade era fomentar e apoiar o teatro amador, incentivar o intercâmbio entre os grupos e oferecer alguns serviços jurídicos e administrativos. Não tinham sede própria, usavam o espaço do Clube do Teatro ${ }^{263}$, e sua maior contribuição foi a criação

\footnotetext{
${ }^{260}$ Id. Ibid.

${ }^{261}$ Guarnieri conta que: "O TPE estava sem dinheiro e havia um programa da Cacilda Becker na TV Record: Uma chance na $T V$, e o primeiro prêmio estava acumulado! Era uma quantia razoável e nós estávamos precisando muito de dinheiro. Resolvemos então tirar a sorte para saber quem iria concorrer. Todos os atores do TPE se inscreveram, e no tirar a sorte eu fui sorteado. Fui, fiz um papel na peça do O`Neill: Onde a cruz está marcada, e ganhei o prêmio. [...] foi ao vivo e era um programa badaladíssimo, era Cacilda Becker! O Júri era todo formado de primeiros atores, coisa fina”. (GUARNIERI, G. In: KHOURY, S. Op. Cit., 1984, p. 26).

${ }^{262}$ A ascensão dos grupos amadores no início dos anos 50 apresenta uma diferença importante em relação aos amadores que renovaram a cena teatral brasileira no início dos anos 40. Projetos de políticas culturais, congressos, comissões e conferências dão o tom das perspectivas na década de 50, pós intensa crise teatral. A construção dos teatros na periferia pela prefeitura de São Paulo e programas de estímulo à circulação das companhias por esses teatros fizeram parte desse novo momento.

263 "O Clube de Teatro foi fundado em 21 de abril de 1951. A instituição era financiada por uma sociedade que em troca podia assistir a uma apresentação teatral por mês" (ROSA, M. W. G.; FÍGARO, R. (orientação). Teatro Amador - Cultura de Estado: políticas públicas e censura em relação ao teatro amador. Relatório final CNPQ/PIBIC - Escola de Comunicações e Artes, Universidade de São Paulo, 2008).
} 
do Festival de Teatro Amador ${ }^{264}$, que realizaram em conjunto com o Clube. A Comissão

Estadual de Teatro (CET) garantiu uma verba para os dois primeiros festivais ${ }^{265}$. Após

cada Festival seguia-se um congresso em que se discutiam os problemas do teatro amador e organizavam propostas a serem desenvolvidas ao longo do próximo ano.

\section{Um inspetor nos procura}

Depois da interrupção de A Rua da Igreja, aceitaram uma sugestão de um dos colaboradores do grupo, Raymundo Duprat e passam a trabalhar na peça An inspector calls de John Boynton Priestley. O estreante Duprat assinou a direção ${ }^{266}$. A nova peça do TPE estreou com o título de Um inspetor nos procura no II Festival de Teatro Amador.

De acordo com Vera Gertel, tratava-se de um texto costumeiramente encenado por grupos de teatro amador. De fato, essa peça de Priestley, em geral traduzida como Está lá fora um inspetor, era bem conhecida em São Paulo e no Rio de Janeiro. Foi em

\footnotetext{
${ }^{264}$ O primeiro Festival ocorreu em novembro de 1954, no Teatro Colombo, cedido pelo município (com isenção de taxas). O II Festival acumulou a experiência e os sucessos do primeiro, 40 peças inscritas e 15 selecionadas. Estes festivais foram importantes para o desenvolvimento do teatro nacional, lançaram e deram oportunidades a muitos grupos. "No primeiro ano, com patrocínio da Secretaria de Educação e Cultura de São Paulo, que cedeu, com isenção de taxas municipais, o Teatro Colombo, foi realizado o I Festival Paulista de Teatro Amador, entre 7 e 23 de novembro de 1954, seguido do I Congresso Paulista de Teatro Amador, nos dias 25 a 28 de novembro. Com o sucesso da primeira edição do festival, em 1955 na segunda edição, o Festival recebeu inscrição de 40 peças. E, a partir da terceira edição, os espetáculos premiados realizaram temporada no Teatro Leopoldo Fróes, uma semana cada" (ROSA, M. W. G. Op. Cit., p. 32).

${ }^{265}$ ROSA, M. W. G. Op. Cit.

${ }^{266} \mathrm{O}$ elenco que participou da montagem no Festival era o seguinte: Pedro Paulo Uzeda (no papel de Arthur Birlinh), Diorandy Vianna (como o noivo Gerald Croft); Vera Gertel (como a filha e noiva Sheila Birling); Mariúsa Vianna (como a mãe Sybil Birling); Horieta Branco Batista (no papel da empregada Edna); Oduvaldo Vianna Filho (no papel do conturbado filho Eric Birling); Gianfrancesco Guarnieri (no papel do Inspetor Goole). contra regra: Júlio Elman; cenários: Barbosa de Araújo; Maquiagem: Victor Merinoff; direção geral de Raymundo Duprat. Em entrevista para A Revista do Teatro Amador, de dezembro de 1955, Vianinha comenta que a partir de 6 de janeiro fariam uma temporada com a peça $U m$ Inspetor nos procura, no Teatro de Arena, mas não encontrei referência sobre essa montagem. Houve uma apresentação de Está lá fora um inspetor (agora com esse nome) e de O impetuoso capitão Tic no teatro Novos Comediantes, dirigido por José Fraga, em janeiro de 1956. O elenco havia mudado, Raul Cortez entrou no papel de Gerald Croft (antes realizado por Diorandy Vianna).
} 
1950 a peça de estreia do Grupo de Teatro Amador ${ }^{267}$ (GTA), no Teatro Municipal de São Paulo, dirigida por Evaristo Ribeiro. Raymundo Duprat, que a sugeriu ao TPE, era, naquele momento, ainda integrante do Grupo de Teatro Amador ${ }^{268}$.

Aparentemente, um dos motivos da escolha da peça pelo grupo foi o grande sucesso que fazia por onde passava desde a estreia ${ }^{269}$. Tornou-se, na Inglaterra, referência como crítica à sociedade inglesa vitoriana e seus temas dão a ver uma defesa de princípios socialistas, de qualquer modo associados ao autor. Está lá fora um inspetor pode ser entendida como uma alegoria da espoliação no capitalismo, ao menos em seus temas mais evidentes. O cenário é urbano, de crescente industrialização, bastante expressivo dos problemas congênitos ao avanço do capital. As personagens da família burguesa são algo abstratas - muito embora no texto seja mantida a estrutura dramática do conflito. E a personagem cuja trágica morte é a engrenagem central dos acontecimentos é uma trabalhadora.

O texto de três atos se passa em 1912, em meio às turbulentas lutas de classes na Inglaterra, que precederam a primeira Guerra Mundial. Os acontecimentos transcorrem todos em uma única noite na vida da rica e poderosa família de um industrial, Birling, quando ele e sua família estão comemorando o noivado da filha Sheila com Gerald Croft, filho do principal concorrente da Birling and Company. O noivado significa a

\footnotetext{
${ }^{267}$ Grupo de Teatro Amador de São Paulo foi idealizado e fundado pela Sra. Esther Mindlin Guimarães, em junho de 1950. Ítalo Rossi, que dirigiu a peça seguinte do TPE também era integrante do GTA. No elenco de Está lá fora um inspetor estavam, por exemplo, Esther Mindlin Guimarães, Clóvis Garcia e Eny Autran Ribeiro.

${ }^{268}$ Depois, em 1952, a mesma peça foi apresentada pela Cia. Barreto Pinto, com direção do português João Villaret, no Theatro Serrador, no Rio de Janeiro. No elenco estavam Fernanda Montenegro - ainda praticamente desconhecida - e Sadi Cabral, entre outros. João Villaret havia encenado esta peça em Portugal com enorme sucesso, foi então contratado pelo deputado Barreto Pinto (cujo maior destaque na vida política foi o pedido de cassação de registro do PCB) para repetir o mesmo feito no Brasil, só que aqui a peça não fez sucesso.

${ }^{269}$ A estreia de An inspector calls foi em 1945 na União Soviética, em Moscou e depois em Leningrado (Teatro Karmeny em Moscou e no Teatro de Comédia em Leningrado). Na Inglaterra só foi encenada no ano seguinte, no New Theatre, em Londres. A primeira produção da Broadway deu-se no Teatro Booth em 21 de Outubro 1947 e seguiu até 10 de janeiro de 1948. (BROWN, I. J. C. J. B. Priestley. London: Published for the British Council and the National Book League by Longmans, Green, 1964).
} 
expansão dos negócios, pois as empresas iriam se fundir. Arthur Birling faz um caloroso discurso para os noivos explicitando seu real interesse:

BIRLING - Esta é uma das noites mais felizes da minha vida. [...] Gerald, ia precisamente dizer-lhe, com toda a sinceridade, que seu noivado com Sheila tem para mim uma excepcional importância. [...] É justamente a espécie de genro que eu sempre desejei. Seu pai e eu há muito que somos amistosos rivais em negócios... embora Crofts Limits seja mais antiga e maior que Birling and Company. Mas vocês, agora, nos uniram, e já podemos vislumbrar no futuro o momento em que Crofts e Birlings deixarão de ser competidores, para trabalharem em comum... obtendo custos mais baixos e preços mais altos. ${ }^{270}$

Tudo vai muito bem até que a empregada Edna notifica a chegada inesperada de um homem identificado como Inspetor Goole. O misterioso homem se identifica como investigador da polícia e dá início a um interrogatório sobre o suicídio de uma mulher trabalhadora, Eva Smith (também conhecida como Daisy). Um a um, todos os membros da família são interrogados e todos de alguma maneira, por aspectos distintos, revelamparticipantes na morte da jovem, cuja desgraça tem início ao ser despedida da fábrica de Arthur Birling, o chefe da família, após liderar uma greve por melhores salários. O inspetor traz consigo o diário da vítima e uma fotografia, que ele só mostra a um de cada vez. Durante o interrogatório, as pessoas não sabem que aquela a quem fizeram mal era a mesma pessoa sobre quem discutiam na conversa anterior. Durante o interrogatório as relações entre os familiares ficam estremecidas, aspectos sombrios são revelados. Sheila e Eric, filhos dos Birlings sentem-se culpados - ainda não teriam sido

\footnotetext{
${ }^{270}$ PRIESTLEY, J. B. Está lá fora um inspetor. Petrópolis: Editora Vozes, 1966, p. 13.
} 
completamente dominados pelo pragmatismo frio do jogo capitalista. Quando todos sentem que aquela revelação significava a ruína, o inspetor Goole faz um último discurso, que parece confundir-se com o discurso do próprio autor:

INSPETOR (voltando-se para a porta) - Mas nunca mais se esqueçam. Uma Eva Smith se foi... mas há ainda milhões e milhões de Eva Smith e John Smith junto de nós, com suas existências cheias de esperanças e temores, de angústias e de anseios e de felicidade. Suas vidas estão entrelaçadas com as nossas, participando do que pensamos, do que dizemos, e do que fazemos. Ninguém vive isolado. Somos como membros do mesmo corpo. Cada um de nós é responsável pelos outros. Se a humanidade não aprender esta lição, eu lhes digo que breve virá o tempo em que isto será ensinado a ferro, sangue e angústia. Boa noite. (Ele sai calmamente, deixando-os surpresos, subjugados e aturdidos) ${ }^{271}$.

O tom de suspense se mantém por mais algum tempo, mas logo o noivo Gerald e Arthur desconfiam de que se trata de alguma brincadeira de mau gosto. Afinal, ninguém tinha certeza de que falavam da mesma moça, pois o Inspetor Goole não deixou que vissem a foto juntos. Ele poderia, portanto, ter induzido a que acreditassem que a família seria responsável pela miséria e suicídio de uma mesma jovem. Talvez, pensam, nem tenha havido morte alguma. Ligam para o departamento de polícia e confirmam que não existe nenhum Inspetor Goole. A seguir telefonam para o Hospital da cidade, que informa não ter havido um caso de suicídio naquele dia. Enfim, tudo não passaria de uma provocação e poderiam retornar às suas vidas. Os noivos que haviam

\footnotetext{
${ }^{271}$ Id. Ibid., p. 109.
} 
praticamente rompido - Gerald havia mantido a suposta jovem suicida como amante retomam a união. O telefone toca e uma pessoa da polícia informa que uma jovem acabara de morrer, "depois de ter ingerido uma certa dose de desinfetante",272. Um inspetor da polícia estaria a caminho da casa dos Birling para interrogá-los. A peça finda envolta numa névoa de mistério.

A tônica da peça não está exatamente na crítica ao capitalismo, mas na condenação à exploração desmedida dos capitalistas. Há de se observar a ausência em cena da classe trabalhadora, apesar de sua presença em espírito ser central para a narrativa. Ela só existe enquanto evocação e a sua posição social é a de completo aniquilamento, sem qualquer protagonismo. De qualquer modo, seu tom antiburguês se combina a uma dinâmica narrativa e a uma estrutura de suspense que certamente despertou a atenção de um público estudantil e popular, contribuindo para seu sucesso.

A leitura dessa peça, entretanto, quando da comparação com A Rua da Igreja, deixa uma impressão de recuo formal. Há certa dissociação entre temas e forma. E sua ênfase moralista no encaminhamento do argumento, na forma da peça de conversação ${ }^{273}$ que gira em torno da defesa de uma questão, lembra o estereótipo do teatro de tese, com a sugestão conciliatória de que todos "somos membros de um mesmo corpo" 274 . Quase tudo o que ficamos a conhecer a respeito das relações entre as personagens se dá a partir de discursos, de conversa. A visão difusamente humanista da peça fazia eco ao pensamento de esquerda daquele período, também dentro do Partido Comunista Brasileiro, que se aproximava da burguesia nacional esclarecida e progressista, supostamente anti-imperialista. Contudo, a temática é pertinente ao Brasil daqueles anos de 1940 e 1950 que vivia um processo de intensificação da industrialização com a política desenvolvimentista da substituição das importações.

\footnotetext{
${ }^{272}$ Id. Ibid., p. 137.

${ }^{273}$ SZONDI, P. Teoria do drama moderno. São Paulo: Cosac \& Naify, 2001, p. 106.

${ }^{274}$ PRIESTLEY, J. B. Op. Cit., p. 109.
} 
A estreia de Um inspetor nos procura no II Festival de Teatro Amador de São Paulo $^{275}$ ocorreu no Teatro São Pedro, em 15 setembro de 1955. Foi registrada como das mais festejadas num festival que mereceu atenção de importantes artistas e intelectuais ${ }^{276}$. Concorreu com outras 14 peças, das 40 inscritas ${ }^{277}$ (Foram, na verdade, 15 peças selecionadas, mas o Teatro Experimental do Negro (TEN), de Abdias do Nascimento, que deveria apresentar João Sem Terra (1949), de Hermilo Borba Filho, de última hora desistiu de sua inscrição por falta de recursos financeiros ${ }^{278}$ ). Guarnieri levou o prêmio de melhor ator. Flávio Rangel, em entrevista com Guarnieri em 1974, comenta que depois daquele festival, Guarnieri e Vianinha foram sondados por praticamente todas as companhias teatrais para integrarem seus elencos ${ }^{279}$.

Olhando para os espetáculos selecionados e apresentados no Festival, é possível observar em todos os participantes um interesse crescente por temáticas brasileiras e populares. Ali se assistiu, por exemplo, uma adaptação dramática que José Carlos

\footnotetext{
${ }^{275}$ O II Festival foi realizado no Teatro São Pedro, entre os dias 10 e 25 de setembro de 1955. A sessão solene de abertura foi no dia 9, no Pequeno Auditório do Museu de Arte, com apresentação de Fedra de Racine, pelo Conjunto Permanente de Leitura Dramática do Museu de Arte (REVISTA DO TEATRO AMADOR, ano 1, $\mathrm{n}^{\mathrm{o}} 3$, out. de 1955, p. 3). De acordo com os editores da Revista do Teatro Amador, estavam presentes no Festival importantes figuras do cenário artístico e intelectual brasileiro, como José Lins do Rego, José Carlos Cavalcanti Borges, Décio de Almeida Prado, Sábato Magaldi, Mattos Pacheco, Nicanor Miranda, Sérgio Cardoso, Nídia Lícia, José Renato.

${ }^{276}$ A Revista do Teatro Amador, em número especial sobre o Festival, considerou que a apresentação do TPE "reuniu um público dos mais numerosos". O TPE teria sido também "muito bem recebido e bastante aplaudido, já pelo próprio texto que consegue prender a plateia até o desfecho, já pela linha de representação" (REVISTA DO TEATRO AMADOR, ano 1, $\mathrm{n}^{\circ}$ 3, out. de 1955, p. 4). Sobre a estreia ver também crítica de Clóvis Garcia em: GARCIA, C. Os caminhos do teatro paulista. São Paulo: Prêmio, 2006 , p. 309.

${ }^{277}$ GARCIA, Clóvis. Op. Cit., p. 303.

${ }^{278}$ Id. Ibid., p. 309.

${ }^{279} \mathrm{O}$ evento também rendeu um convite de Alfredo Mesquita a Guarnieri para ingressar na Escola de Artes Dramáticas, mas o convite foi recusado. A vontade de atuação política através do teatro, de intervenção na realidade era muito mais urgente do que a busca por "formação". Resolveram juntos que naquele momento ficariam firmes em torno do grupo amador.
} 
Cavalcanti Borges fez de Fogo morto, de José Lins do Rego ${ }^{280}$; o grupo Comediantes

Paulistas apresentou a peça A trovoada, de Aristóteles Soares, autor pernambucano com texto inédito em São Paulo ${ }^{281}$. Três, entre as 15 peças selecionadas, eram de autores contemporâneos pernambucanos. Além de Hermilo Borba Filho - ligado às experiências de modernização popular em Pernambuco com o Teatro dos Estudantes de Pernambuco e, posteriormente, o Teatro Popular do Nordeste - Cavalcanti Borges e Aristóteles Soares eram ligados ao Teatro dos Amadores de Pernambuco (TAP), grupo que passara por São Paulo poucos anos antes causando grande impressão ${ }^{282}$. Eram, enfim, autores modernos que procuravam refletir sobre as particularidades nordestinas, sobre as condições de vida do povo, na construção de um diálogo entre a cultura popular e a erudita ${ }^{283}$.

As críticas de Clóvis Garcia para o II Festival de Teatro Amador - e as de Athos Abramo para a Revista do Teatro Amador na mesma linha -, no entanto, não apontam

\footnotetext{
${ }^{280}$ A peça escrita em 1955 foi apresentada pela Associação dos Servidores da Caixa Econômica Federal de São Paulo, com direção de Genivaldo Wanderley. Essa foi a única apresentação da peça do pernambucano José Carlos Cavalcanti Borges em São Paulo. (PONTES, J. O teatro moderno em Pernambuco. São Paulo: Desa, 1966, p. 153).

${ }^{281}$ O texto A trovoada de Aristóteles Soares havia estreado em 1949, no Teatro de Amadores de Catende, em Pernambuco, dirigida por Jaime Albuquerque. O diretor do Teatro de Amadores de Pernambuco (TAP), o Valdemar de Oliveira, assistiu a peça e convidou Aristóteles Soares para escrever para o TAP. (MELO, Jones. Aristóteles Soares - consagrado e esquecido. Diário de Pernambuco, Recife, p. D-4, 2 jul. 1978) “Aristóteles Soares (Rio Formoso, PE, 1910) situa-se numa linha de realismo sombrio, nem sequer amenizada pela alegria do folclore da zona sul de Pernambuco [...]. Seu objeto é gente entocada na família, e exangue de miséria física, tuberculoses, doidos, anêmicos, à força do jejum. O povo curte sofrimentos seculares, com alguns intervalos de sonho, como este de $A$ trovoada: "Quantos não desejam isso, uma nesga de terra? Bastava uma nesga para cada um. Cada um fazia a sua roça. Cada um tinha a sua morada certa e ao andava de usina em usina como judeu errante". Esta realidade - da monocultura da cana, que açambarca grandes extensões e terra, impossibilitando qualquer outra atividade agrícola, mesmo de pequeno porte - aplasta os pobres como uma força bruta da natureza, impossível de ser controlada. Os personagens não veem o tipo errado de exploração de terra; sentem os seus efeitos, impotentes e solitários" (PONTES, J. Op. Cit., 1966. p. 147).

${ }^{282}$ O TAP, fundado em 1941 por Valdemar de Oliveira, José Carlos Cavalcanti Borges, entre outros, havia circulado em 1953 pelo Sul e Sudeste do Brasil: "obtendo ampla repercussão nos meios culturais", de acordo com Nanci Fernandes (FERNANDES, N. Os grupos amadores. In: FARIA, J. R. (Org.). História do teatro brasileiro. São Paulo: Editora Perspectiva e SESC/SP, 2013, p. 77). Em 1955 o TAP veio a São Paulo e participou dos festejos do IV centenário. Segundo Clóvis Garcia, a passagem do grupo por São Paulo deixou impressão profunda, pela excelência do trabalho, "que faltam a muitas das nossas companhias profissionais" (GARCIA, C. Teatro de Amadores de Pernambuco, O cruzeiro, São Paulo 12.03.1955. In:__ Op. Cit. p. 266). Nesta ocasião o grupo também apresentou seu repertório internacional, curiosamente, dentre tais peças, uma montagem de Está lá fora um inspetor.

${ }^{283}$ PONTES, J. Op. Cit., 1966. p. 147; FERNANDES, N. Op. Cit., p. 77.
} 
para as questões temáticas em jogo, nivelando todas as apresentações por critérios técnicos como: "qualidades cênicas", "boa direção", "atuação" etc.

Além da representação de peças de autores modernos pernambucanos é possível perceber pelo conjunto do Festival, um interesse considerável em levar à cena comédias com perspectiva populares, muitas delas de autores nacionais como Arthur Azevedo, Martins Pena e Paulo Gonçalves. O Pequeno Teatro Popular ${ }^{284}$, por exemplo, ganhou o premio Arlequim de melhor espetáculo com três peças em um ato dirigidas por Emilio Fontana: Uma mulher na gaiola, de P.S. Laughlin; Amor por anexins, de Arthur de Azevedo e Palavras trocadas, de Alfredo Mesquita (que havia estreado com ótimas críticas no Teatro de Segunda-feira do TBC, com elenco da EAD) ${ }^{285}$.

Por outro lado percebe-se também que o repertório internacional mantinha semelhanças com aquele desenvolvido no mesmo período pelo TBC, com uma exceção significativa observada no trabalho do Teatro Lotte Sievers, que apresentou duas peças inéditas no Brasil, Reunião em família e A cacatua verde, de Arthur Schnitzler (18621931), autor judeu alemão pouco conhecido do público brasileiro, influenciado pela psicanálise. As duas peças foram traduzidas por Lotte Sievers e por Eudynir Fraga ${ }^{286}$.

\footnotetext{
${ }^{284}$ O Pequeno Teatro Popular era formado por um grupo de ex-alunos da Escola de Artes Dramáticas de São Paulo e orientado por um conselho integrado por Décio de Almeida Prado, Alfredo Mesquita e Sábato Magaldi. Tinha como finalidade a difusão das artes cênicas por cidades do interior, sob a forma do teatro de arena. (GARCIA, C. Pequeno Teatro Popular, O cruzeiro, 23.07.1955. In: 292). Op. Cit., p.

${ }^{285}$ Outras comédias brasileiras apresentadas foram: $O$ Oráculo, de Arthur de Azevedo, pelo Grupo Teatral Politécnico e Quem casa quer casa, de Martins Pena, dirigidas por J. E. Coelho Neto; A comédia do coração, texto de 1927, escrito por Paulo Gonçalves, dirigida por J. E. Coelho Neto para o Clube do Teatro; Morre um gato na China, de Pedro Bloch, autor do teatro profissional, foi apresentado pelo Teatro Amadores Paulista, com direção de Wanda Barcelos. Clóvis Garcia, no entanto, lamentou a escolha desse texto, que considerava de valor secundário. Ele disse não entender o motivo de ter sido "encenado por amadores que não necessitam de recursos comerciais". (GARCIA, C. Op. Cit., p. 309).

${ }^{286}$ Dos autores modernos clássicos, foram apresentadas duas peças de Pirandello: Seis personagens em busca de autor, pela Sociedade dos Artistas Independentes, com direção de Oswaldo Pisani; e $O$ imbecil, pelo Teatro Experimental Mem de Sá, também direção de Oswaldo Pisani. A importância de ser severo, de Oscar Wilde, foi apresentada pela A. A. Matarazzo, com ambientação "brasileira" e transposição para a época atual. (GARCIA, C. Op. Cit., p. 310.). O Festival teve ainda a apresentação da Escola Teatral dos ex-alunos salesianos de Dom Bosco, com uma peça chamada Suicídio, de Franco Roberto e tradução de João Rosa da Silva e outro texto nacional inédito apresentado pelo Teatro Paulista, Cão Morto, de Vicente Eduardo Scrivano. (Relação das peças apresentadas: REVISTA DO TEATRO AMADOR, ano 1, n 3 , out. de 1955 , p. 8).
} 


\section{Tese para um teatro nacional e popular}

Entretanto, o que parece ter mais chamado atenção com relação ao trabalho do Teatro Paulista do Estudante durante o festival - e no congresso que se seguiu - foi sua diferença em relação a outros coletivos que pareciam agrupamentos mais instáveis e menos organizados em torno de um programa. Foi essa a impressão suscitada em muitos observadores da época. O TPE se distinguia, naquele momento, pela qualidade de elenco, e pela atitude politizada diante do ambiente.

Terminado o Festival teve início o II Congresso Paulista de Teatro Amador ${ }^{287}$, realizado no Auditório do Museu de Arte de São Paulo e na sede da Associação Atlética Matarazzo. O TPE participou ativamente desse encontro, apresentando uma tese publicada com destaque no número seguinte da Revista de Teatro Amador, em janeiro de 1956. Seus integrantes se mobilizaram para que esse movimento do teatro amador paulistano se ampliasse para todo o território nacional ${ }^{288}$, fortalecendo a ideia de maiores apelos ao financiamento governamental - o que ecoava a ideia corrente na Europa do pós-guerra que defendia o teatro como serviço público. Os propósitos que moviam o grupo ganharam contornos mais nítidos a partir desse contato com outros grupos amadores.

\footnotetext{
${ }^{287}$ A Revista do Teatro Amador $\mathrm{n}^{\circ} 3$ apresenta um balanço do que foi o II Congresso.

${ }^{288}$ Tese esta que, segundo os editores da Revista, seria responsável pela criação de um Festival de Teatro Nacional, em São Paulo: "as teses do TPE sobre a divulgação de nossa cultura indicando medidas que visam um maior intercâmbio entre os grupos amadores a instituição de um concurso de peças, a realização de um Festival de Teatro Brasileiro" (REVISTA DO TEATRO AMADOR, ano 1, n ${ }^{\circ}$ 3, out. 1955). Depois, em janeiro de 1956, A Revista do Teatro Amador $\mathrm{n}^{\circ}$ 6, trouxe um artigo divulgando a ideia do Primeiro Festival brasileiro de teatro amador: "O II Congresso Paulista de Teatro Amador aprovou a realização do I Festival Brasileiro de Teatro Amador [...]. Com o intuito exclusivo de prestar serviços a uma arte tão necessária ao desenvolvimento cultural de um povo e presumindo possuir a indispensável prática na organização de Festivais de Teatro Amador, a Federação e o Clube de Teatro aceitaram a honrosa incumbência e já se lançaram a campo. [...] A época provável da realização será setembro deste ano e o local será São Paulo, provavelmente no Theatro Municipal" (REVISTA DO TEATRO AMADOR, Ano 1, nº 6, jan. 1956).
} 
A tese $O$ teatro amador em defesa de nossas tradições culturais $^{289}$ apresentada pelo TPE no congresso é uma síntese dos objetivos do grupo naquele momento. Há ali uma defesa do amadorismo como possibilidade experimental e política no teatro e a formulação da ideia de arte nacional popular que se realizaria no trabalho do Arena nos anos seguintes. Como se vê, apesar do afastamento de Ruggero Jacobbi, suas ideias continuaram a balizar o projeto do grupo, combinadas com o imaginário de uma eficácia militante.

O TPE apresenta propostas de ordem produtiva e funcional, no sentido de refletir sobre a importância que o teatro amador poderia adquirir cultural e politicamente, justamente porque, como já dissera Ruggero Jacobbi, não tinha as amarras financeiras dos grupos profissionais. Ao mesmo tempo em que explicitavam a necessidade de subsidio estatal e o constante descaso com isso, apontavam para saídas mais imediatas, que não precisassem depender do poder público. A ideia de fortalecer e criar alianças entre os grupos amadores e os grupos profissionais foi pautada pelo TPE nesse congresso. Eles, que já estabeleciam uma parceria com o Teatro de Arena, viam nesse caminho uma possibilidade de fortalecimento do teatro como um todo, no sentido de sanar algumas deficiências características das duas condições, do teatro amador e do profissional.

Tanto o teatro amador como o profissional sofriam com a ausência de financiamento público. Contudo, os profissionais, para sobreviver, segundo a análise exposta no Congresso, precisavam aumentar o preço da bilheteria, mantendo de fora o povo, "impossibilitado de ver esse teatro". Já o Teatro Amador, que também lutava contra a "incúria governamental", tinha maior flexibilidade para se aproximar do povo. Merecia, pois, uma atenção especial. Assim, segundo a tese do TPE, enquanto o teatro

\footnotetext{
${ }^{289}$ TEATRO PAULISTA DO ESTUDANTE. O teatro amador em defesa de nossas tradições culturais. Revista do Teatro Amador, ano I, nº 6, jan. 1956, p. 5. (Ver anexo)
} 
profissional, diante das limitações financeiras, ficava restrito a uma "minoria de abastados", o público dos espetáculos amadores era popular:

Temos que notar, ainda, a facilidade que possui o Teatro Amador em penetrar nas fábricas, escolas e fazendas, proporcionando assim a operários, estudantes e camponeses o contato com o teatro, levando a mensagem dos autores realmente em meio ao povo ${ }^{290}$.

A maior força do teatro, para os autores da tese, era seu poder de "influência direta sobre o povo". E era o teatro amador que poderia ser a vanguarda de um novo momento para o teatro nacional.

\begin{abstract}
Vemos quão importante é o Teatro Amador, particularmente no momento atual, e quanto é grande a responsabilidade dos que se dedicam a esse teatro. Se de um lado o Teatro, como todas as manifestações artísticas, pode educar, divertir, incentivar, mal orientado poderá transviar, degenerar, entorpecer ${ }^{291}$
\end{abstract}

A responsabilidade do artista, portanto, seria grande. Os artistas de teatro deveriam começar a refletir sobre sua função social:

Os problemas de cultura não vivem independentemente de problemas políticos e econômicos. Um povo entorpecido é um povo que na sua passividade se entrega à rapina e à escravidão. Um povo que não ama, não quer, não luta. E a cultura destinada a entorpecer um povo é

\footnotetext{
${ }^{290}$ Id. Ibid., p. 5.

${ }^{291}$ Id. Ibid., p. 5.
} 
aquela que se desliga desse mesmo povo, que se desvencilha de seus sentimentos, paixões e aspirações; é a que foge dele, é a que abstraindo-se do humano, deturpa e entorpecer ${ }^{292}$.

De modo contrário, o teatro teria a função de despertar a consciência crítica para os problemas sociais, de organizar e reconectar o povo em torno de "sentimentos, paixões e aspirações"293 comuns. Para isso, pragmaticamente, era preciso que aparecessem novos autores que procurassem refletir a vida social na dramaturgia. Como medida de incentivo ao autor nacional, o TPE sugeria um concurso de dramaturgia e a criação de um Festival de Teatro Brasileiro.

Mas esse movimento não poderia ser de mão única, com os intelectuais e artistas sendo os únicos transmissores de aspectos culturais e políticos. Quando esse artista assumisse um lado da história e se ligasse realmente ao povo, esperava-se não que ele somente apresentasse novas perspectivas críticas ao povo "inculto", mas que identificasse, elaborasse e representasse a realidade daqueles excluídos do mundo da cultura. Trata-se de um movimento dialético de identificação e ao mesmo tempo saberse outro.

Embora o sofrer de nosso povo seja imenso, nosso povo canta, nosso povo representa, escondido nas mais variadas regiões de nossa terra. [...] E homens tivemos que nas letras e nas artes souberam transmitir o sentimento de nosso povo ${ }^{294}$.

\footnotetext{
${ }^{292}$ Id. Ibid., p. 5.

${ }^{293}$ Id. Ibid., p. 5.

${ }^{294}$ Id. Ibid., p. 5.
} 
Ainda que de maneira genérica, eles defendem a necessidade de tomar conhecimento da herança cultural popular, produzida pelo povo. Seria necessário que os artistas amadores fossem ao encontro dessas manifestações culturais, que aprendessem com elas.

Nessa tese aparecem as influências convencionais do Partido, a ideia de uma "arte que não pode se afastar do destino do povo", com temas operários e ao mesmo tempo folclóricos, recuperando uma tradição popular e a ideia de mensagem e de "educação do povo"295. Ao mesmo tempo, na argumentação que percorre toda a tese, também saltam aos olhos outras influências (e aí o papel formador de Ruggero Jacobbi se anuncia), sobretudo na constituição de certa ideia de trabalho coletivo entre gerações, em que a luta pela dimensão social do teatro deve ser totalizante. $\mathrm{O}$ que sugere que $\mathrm{o}$ Teatro Paulista do Estudante começava a elaborar uma síntese particular dessas influências, com claro sentido de engajamento político e interesse no aprofundamento estético.

O TPE parece organizar, nessa primeira tentativa de conceituação, um novo arranjo das ideias de nacional popular. A divulgação e criação de obras nacionais com temas humanistas ou populares conviviam com a defesa da aproximação concreta ao povo, dinâmica de aprendizado, interação com uma cultura popular orgânica, com vistas à transformação social. A ideia de teatro como serviço público está claramente presente, mas combinada a uma relativa alteração da função social do teatro na sociedade burguesa.

O teatro havia de ser popular. Há um sentido de eficácia e facilitação nisso: popular no sentido de alcance de um público de massa, tanto na popularização do acesso - barateamento do bilhete de entrada e medidas de financiamento público - como na

\footnotetext{
${ }^{295}$ ZHDANOV, A. As tarefas da literatura na sociedade soviética. Problemas. Revista Mensal de Cultura Política no 20, ago.-set. 1949.
} 
expectativa de comunicabilidade e sucesso. Mas há também um sentido de crítica radical da herança cultural: deslocamento dos artistas para fora do edifício teatral, em direção ao povo, aprendendo com ele, mudando de posição. De qualquer modo, a contradição também se resolvia, por vezes, na fórmula mais instrumental do teatro como ferramenta de conscientização política.

No programa apresentado, um novo teatro amador deveria cuidar:

Da divulgação de obras de conteúdo nacional, impregnadas de humanismo que faz vibrar os povos; do estudo e divulgação de nossas obras culturais; do aprimoramento artístico, da representação de obras mestras de outros povos, deve viver nosso teatro ${ }^{296}$.

Apesar do forte impacto que as teses do TPE causaram no Festival, sendo publicadas com destaque na Revista do Teatro Amador, e também da tendência dominante de peças brasileiras contemporâneas de temática popular no Festival, não parecia existir uma movimentação coesa e organizada do teatro amador que permitisse a radicalização do movimento e o aproveitamento positivo de sua condição não mercantil. A grande maioria dos grupos que surgiam logo desaparecia, seja por motivos financeiros ou por falta de uma orientação clara. Alguns dos melhores quadros buscavam a profissionalização. A Federação cumpriu um papel significativo, agremiando os grupos, criando festivais e a Revista do Teatro Amador. Mas não houve uma mobilização de lutas por políticas públicas e por um avanço de repertório de maneira coletiva. Segundo Maria Thereza Vargas, de modo geral, os grupos amadores desse período nasciam com a tentativa de copiar o repertório em voga, a fórmula de

\footnotetext{
${ }^{296}$ TEATRO PAULISTA DO ESTUDANTE. Op. Cit., p. 5.
} 
sucesso do $\mathrm{TBC}^{297}$. As peças eram montadas especialmente para os Festivais, como muitos dos que se inscreveram em 1955. Os grupos que teriam escapado dessa morte prematura teriam sido o Teatro Lotte Sievers e o TPE, exatamente por quererem algo mais do que "imitar o repertório de uma empresa que já sofrera um longo processo de desenvolvimento"298 e que, inclusive, chegava ao final do ciclo. Se o Teatro Lotte Sievers procurava promover e desenvolver um teatro baseado numa dramaturgia alemã moderna "totalmente ignorada pelo público brasileiro"299, o TPE nascia impulsionado pelas esquerdas e mobilizava a ideia de um projeto "totalmente nacionalizante". ${ }^{300}$ Nos dois casos, o amadorismo servia à liberdade criativa e ao gesto programático que tinha pouco lugar no campo do profissionalismo de então.

O TPE sai desse ciclo de contato com o movimento amador mais convicto de seu propósito militante de conscientização, descentralização e deslocamento do teatro para os lugares periféricos. Em entrevista para o número seguinte da Revista do Teatro Amador, os jovens do TPE falam dos planos que tinham para a continuidade do grupo:

Encontrar um repertório à altura do que até aqui foi apresentado. Se possível montaremos peças de autores nacionais inéditos, o que viria não só incentivar e apoiar o autor nacional, como também facilitar o aparecimento de temas de sabor mais nacional e mais popular, mais acessível, portanto, à grande massa popular que vive afastada das realizações teatrais feitas em nossa terra ${ }^{301}$.

\footnotetext{
${ }^{297}$ VARGAS, M. T. Teatro Amador em São Paulo. Revista Dionysos, Ano XII, nº 15, Rio de Janeiro: MEC-SNT, dez. de 1967, p. 34.

${ }^{298}$ Id. Ibid., p. 34.

${ }^{299}$ O Teatro Lotte Sievers se manteve por cinco anos (1952-1957). A Calça, de Carl Sternheim, direção de Evaristo Ribeiro, estreou no Teatro Cultura Artística em 1953. Os Ratos de Gerard Hauptmann, também teve direção de Evaristo Ribeiro, com um elenco de 15 atores, ficou por 15 dias em cartaz em 1953 no Teatro Cultura Artística. A Cacatua Verde, de Arthur Schnitzler, estreou no Festival em 1955. (VARGAS, M. T. Op. Cit., p. 35)

${ }^{300}$ Id. Ibid., p. 35.

${ }^{301}$ Trecho de entrevista com o TPE na Revista do Teatro Amador, Ano 1, nº 5, dez. 1955.
} 


\section{Pela forma popular}

Ainda que na tese apresentada no II Congresso o TPE não levante explicitamente o debate sobre os caminhos formais, e menos ainda discuta a utilidade da comédia popular, a questão logo aparece em seu campo de interesses.

Os seguintes passos do TPE são tomados nessa direção. Entre outubro e dezembro de 1955, estreitam relação com a Federação e juntos organizam o Festival Artur Azevedo em comemoração ao centenário do autor.

O Festival Artur Azevedo ocorre no MASP, cuja direção do departamento de Teatro estava a cargo de Gianni Ratto. Coelho Neto - então diretor da Federação - foi responsável pelo discurso de abertura. Houve uma palestra de Joracy Camargo e o TPE estreia duas peças em um ato de Artur Azevedo. A primeira delas, Entre o vermute e a sopa foi dirigida por Beatriz Segall (que há pouco se aproximara do grupo), com Vera Gertel, Romeu Pacheco e Maria Célia Camargo (que havia estudado com Ruggero Jacobbi). Ao mesmo tempo, José de Lima, integrante do TPE, dirigiu ainda Amor por anexins, com Maria Célia Camargo, Flávio Migliaccio e Geraldo Fernandes na atuação.

As peças conseguem uma boa aceitação do público e mesmo da crítica. A realização de um festival em torno de um autor brasileiro popular parecia confirmar os propósitos lançados no II Congresso, como se vê pelo entusiasmo do colunista da Revista do Teatro Amador:

As nossas impressões sobre o Festival Artur Azevedo foram as melhores possíveis, pois, tivemos a oportunidade de assistir, além da bonita palestra de Joracy Camargo, a um desempenho convincente, dentro de uma reunião de entusiastas que bem vem a acalentar e 
animar a largada em busca de um grande e verdadeiro teatro nacional $^{302}$.

Na mesma linha da comediografia popular, em 7 de novembro de 1955, o TPE estreia uma peça inédita no Brasil do francês Eugène Labiche, $O$ impetuoso capitão Tic. A montagem, apresentada no Teatro de Arena, às segundas-feiras, marcou a estreia de Raul Cortez como ator no grupo. Teve direção de Ítalo Rossi ${ }^{303}$, que nesta época atuava no Arena. O programa do espetáculo já registra que o trabalho era uma produção do Teatro de Arena, evidenciando o vínculo maior que em breve resultará na fusão ${ }^{304}$.

Àquela altura, Flávio Migliaccio, já estava no TPE. De origem operária, morador do Tucuruvi, ele vinha da experiência de teatro em Igreja. Em 1954 havia participado de um curso - que durou o ano todo - oferecido por Ruggero e Carla Civelli para as comemorações do IV Centenário da cidade de São Paulo. Ao final do curso, Jacobbi o convida a se juntar ao pessoal do TPE:

Terminou o curso e Ruggero perguntou: "E você vai fazer o quê agora?” - “ Não sei, vou voltar lá pro Tucuruvi, porque minha vida acabou". Aí ele falou: "não, eu vou te apresentar um grupo amador". Me levou para a Avenida Paulista e tinha um grupo pedindo dinheiro no trânsito pra fazer um espetáculo - "Olha eles lá". Chegamos perto e estavam o Vianinha, o Guarnieri, a Vera Gertel, o pessoal do Teatro Paulista do Estudante. Eu lembro que o Vianinha me perguntou: "Você quer entrar no grupo mesmo?" Eu falei: "Eu quero". E ele:

\footnotetext{
${ }^{302}$ REVISTA DO TEATRO AMADOR, ano I, $\mathrm{n}^{\mathrm{o}}$ 5, dez. 1955, p. 8.

${ }^{303}$ Ele havia sido dirigido por Ruggero Jacobbi em A esquina da Ilusão em 1953. Em 1955 atuou em duas peças do Teatro de Arena, como ator: O prazer da honestidade, de Luigi Pirandello, com direção de Carla Civelli e Não se sabe como, também de Luigi Pirandello, com direção de José Renato. Em 1956 é contratado pelo TBC. E em 1959 foi um dos fundadores do Teatro dos Sete.

${ }^{304}$ Programa da peça $O$ impetuoso capitão Tic, de Eugene Labiche, direção de Ítalo Rossi.
} 


\begin{abstract}
“Então segura a ponta desse lençol”. Eles estavam pedindo dinheiro com um lençol. Eu segurei a ponta do lençol e comecei a pedir dinheiro para o espetáculo deles. Foi assim que entrei para o Teatro Paulista de Estudante ${ }^{305}$.
\end{abstract}

Segundo Dênis Moraes foram ao todo 15 dias de ensaios "a todo vapor" para a montagem de $O$ impetuoso capitão Tic. Ficaram com a peça em cartaz por quatro semanas $^{306}$. Há indícios de que durante os ensaios, Diorandy Vianna quebrou os dentes em uma briga - não sabem se de verdade ou em um ensaio da peça - e por isso precisou ser substituído ${ }^{307}$. Raul Cortez, convidado por Ítalo Rossi, foi quem o substituiu. ${ }^{308}$ Mas é provável que Flávio Migliaccio, no papel do empregado, tenha sido o centro cômico da peça, ainda que a atuação de Guarnieri também tenha sido na época muito comentada.

A Ruggero Jacobbi, que traduziu a peça e a sugeriu ao TPE, o texto de Labiche interessava por sua capacidade de comunicação direta, sem os "profundismos" próprios do teatro dramático em voga. Teria a vantagem de apresentar o homem em traços característicos, revelando um esqueleto de estruturas sociais e relações de poder. Por outro lado, a forma popular bem tramada da farsa de Labiche influenciou decisivamente a obra de autores brasileiros como Artur Azevedo ${ }^{309}$, por quem o grupo já demonstrara interesse. E num certo sentido, a crítica ideológica estava presente na peça. Labiche viveu o auge da afirmação da burguesia, bem como o golpe de Estado do 18 Brumário

\footnotetext{
${ }^{305}$ Entrevista com Flávio Migliaccio, Rio de Janeiro 14.07.2015

${ }^{306}$ MORAES, D. Vianinha cúmplice da paixão. Rio de Janeiro: Ed. Record, 2000, p. 55.

${ }^{307}$ Tiche Vianna (filha de Mariúsa e sobrinha de Diorandy), em entrevista para esta pesquisa, contou que essa história circulava em sua família.

${ }^{308}$ No elenco estavam: Raul Cortez (Horace Tic); Thales Maia (Bernard) Mariusa Vianna (Mme. Guy); Méa Marques (Lucille) e Vera Gertel (também no papel de Lucille); Flavio Migliaccio (Batiste); Gianfrancesco Guarnieri (Desambrois); José de Lima (Celestin Magis) Convidados: Margot Veras; Fabio Goldman. Os integrantes do TPE provavelmente conheceram Raul Cortez no grupo de Lotte Sievers, onde atuou em A Cacatua Verde.

${ }^{309}$ Cf. PRADO, D. A. História Concisa do Teatro Brasileiro. São Paulo: Edusp, 1999, p. 166.
} 
em 1848. Sua comédia, escrita em 1861, se passa justamente durante a Segunda República Francesa de Napoleão III.

O impetuoso capitão Tic conta a história de um ex-comandante da cavalaria que volta para casa após lutar na Guerra do Ópio ${ }^{310}$. Horace retorna pretendendo viver de aposentadoria junto com a tia, que ajudou a criá-lo. Ele traz consigo Bernard, um exsoldado que teria salvado sua vida. O soldado, quando retorna à vida civil, continua subordinado ao capitão, agora na posição de empregado não assalariado, uma espécie de agregado. Toda feita de situações cômicas e farsescas, a peça conta a história desse capitão que se apaixona pela sobrinha, que por sua vez estava prestes a oficializar o noivado com um homem das ciências positivistas, Magis. Depois de muitas idas e vindas, do embate entre a ciência - completamente alheia à realidade - e a brutalidade da ordem militar, depois de toda sorte de confusões e mal entendidos, finalmente os primos tornam-se noivos.

O primeiro ato tem inicio com o Capitão Horace Tic e o soldado Bernard na casa da tia de Horace, de madrugada. Pela conversa entre os dois são apresentadas as circunstâncias da peça. Ele voltava da batalha na China, onde perde o posto. Ficamos sabendo da relação mantida pelos ex-combatentes, e do convite para a que o vínculo de dependência se mantenha:

HORACE - [...] creio que nos sentiremos bem aqui... que diz você?

BERNARD (sentado em frente ao superior, sobre a caixa onde estava a porcelana) - Eu também capitão?

HORACE - Por Baco! Você está imaginando que vai me deixar?

Quer por acaso, voltar para sua casa?

BERNARD - Oh! A minha casa... é o meu capitão!

\footnotetext{
${ }^{310} \mathrm{Na}$ segunda guerra do ópio, entre 1856 a 1860, a França torna-se aliada da Inglaterra contra a China, pelo domínio ocidental.
} 
HORACE - Ainda bem! ... Jamais esquecerei os acidentados dos anos que passamos juntos ${ }^{311}$.

Durante toda a peça vemos que os códigos do mundo antigo, códigos de honra e servidão - algo presentes no universo e na hierarquia da cavalaria - adentram as relações de trabalho, de classe, do mundo burguês. O choque entre esses dois mundos revela o velho contido no novo, as aparências de novidade que mascaram relações antigas. As relações de favor e servidão continuam a operar e, ao mesmo tempo, descortinam as ideologias do mundo burguês e seu fundamento na exploração do trabalho alheio:

HORACE - Como é preciso dar a melhor ideia possível da educação do exército francês... você vai me fazer o favor de achar tudo encantador, perfeito, arrebatador!

BERNARD - Combinado!

HORACE - E nas horas vagas... quando você se aborrecer, se quiser ser agradável, poderá ajudar um pouco a gente da casa... ${ }^{312}$

Foi a impetuosidade de Tic no passado que o levou ao pedido de desligamento do exército. Ele promete a tia - Madame de Guy Robert - que irá tentar conter seu grave defeito, a cólera, e viverá o resto de seus dias ao lado dela com a renda da aposentadoria, numa vida tranquila, como um pequeno-burguês. Mas ao reencontrar a prima mais nova, Lucille, o volúvel Horace muda imediatamente seus planos de criar cavalos e não se casar. Recebe então a desagradável notícia de que a prima estava com

\footnotetext{
${ }^{311}$ LABICHE, Eugene. O Impetuoso Capitão Tic - comédia em três atos. Material datilografado, sem registro de tradução, Biblioteca da Escola de Comunicações e Artes - ECA, USP.

${ }^{312}$ Id. Ibid.
} 
casamento arranjado. O tutor da moça, senhor Desambois, levaria naquele dia o pretendente para conhecer a moça. O excesso de formalismo do tutor e do pretendente, Celestin Magis, denota traços de frivolidade característica de sua condição social. Ambos são ideólogos positivistas, visão bastante ridicularizada por Labiche ao longo da peça.

No resto da trama há uma série de quiproquós, derivados de mal entendidos entre personagens. Labiche coloca em choque três extratos sociais: a família, mãe e filha que estão para receber herança do pai; o militar que sai para lutar na Guerra do Ópio e é marcado por valores aristocráticos (códigos de honra), bem como pela matéria bruta da violência; e a intelectualidade idealista, completamente afastada da realidade material, ao mesmo tempo movida por interesses (a herança de Lucille).

Exemplo do modo cômico da peça é a cena da dança de salão em que o positivista Magis, ao dançar com Lucille não cessa de pisar em seus pés:

MAGIS - Madame, a estatística é uma ciência moderna e positiva. Ela traz à luz os fatos mais obscuros. Assim, ultimamente, graças à exaustiva pesquisa, conseguimos saber com toda exatidão, o número de viúvas que passaram pela Ponte Nova, durante o curso do ano de 1860.

HORACE - Não diga!

DESAMBOIS - É prodigioso! Quantas foram?

MAGIS - 13.498!... e uma duvidosa.

DESAMBOIS (tirando a sua caderneta) - Permita... (escrevendo) 13.498... ele é prodigioso!

HORACE - Não esqueça a duvidosa ${ }^{313}$.

\footnotetext{
${ }^{313}$ Id. Ibid.
} 
Ruggero Jacobbi incluía entre seus interesses autores já descartados pelos setores intelectualizados por se associarem os padrões convencionais do passado. Mas no teatro comercial do passado encontrava exemplos de vitalidade estética e percepção social que poderia contribuir para a abertura de padrões em relação às formas hegemônicas da modernização teatral no Brasil. Assim, era em sentido polêmico que surgiam seus elogios a escritores tidos como menores como Sardou e Labiche. Para Jacobbi, as farsas, se lidas atentamente, ofereciam lições de materialismo desde que suas estruturas de ação não se ocultassem por completo. Nesse sentido, peças escritas na segunda metade do século XIX, ainda serviriam para a percepção da farsa e da hipocrisia ideológica do mundo burguês.

O depoimento de Guarnieri sobre a encenação dá indícios de que os interesses de alguns dos integrantes do grupo, a partir dali, se intensificavam no que se refere à pesquisa da atuação, o que era estimulado por Jacobbi:

Eu pensei: “Opa, esse negócio é bom! Estou gostando!”. O Ruggero Jacobbi começou a me incentivar muito. No TPE montamos uma peça de Labiche, $O$ impetuoso capitão Tic, e o meu papel era muito engraçado, o Desambois, um velho francês. Ruggero então me disse que esse papel seria um grande teste pra mim. Recomendou bastante sobre o problema do tempo em comédia, mas como até hoje, como ator, sou um pouco inconsciente, cheguei na maior tranquilidade, na maior simplicidade e o publicou adorou... riu bastante de tudo que eu fazia... Essa peça foi dirigida pelo Ítalo Rossi e era também a estreia de Raul Cortez no TPE. Quando acabou o espetáculo o Ruggero me chamou num canto e disse: "Pronto, agora é sua vez. Larga tudo e 
segue sua vida de ator que você tem uma carreira brilhante pela frente". Pensei, pensei, olhei pra ele e respondi: "Sinto muito, mas não posso largar o TPE, meu negócio é o TPE”314

Poucos meses depois ele não estaria de fato largando o TPE, mas alguns de seus principais integrantes dariam um passo rumo à profissionalização com a fusão ao Teatro de Arena. É certo, entretanto, que a montagem promoveu, além do amadurecimento técnico do conjunto de artistas, uma maior consciência sobre as possibilidades de interpretação crítica do material dramatúrgico.

Em um artigo sobre O Impetuoso Capitão Tic, o crítico Delmiro Gonçalves faz uma reflexão reveladora sobre a abordagem do grupo da farsa francesa. Diz ele que da maneira como a encenaram, a peça poderia se situar no Brasil:

A comédia de Labiche, tal como foi apresentada pelo Teatro Paulista do Estudante, na encenação de Ítalo Rossi, poderia muito bem passar por uma das peças de Martins Pena, com ligeiras mudanças no passado de umas duas personagens e localizado a ação no Rio de Janeiro. Se o Capitão Tic estivesse de volta de uma das campanhas revolucionárias da China, passaria muito bem, e as demais personagens, por um militar brasileiro, pois as complicações em que se vê envolvido e as reações das demais figuras, tal como foram compreendidas pelo encenador, são típicas da nossa comédia de costumes $^{315}$

\footnotetext{
${ }^{314}$ GUARNIERI, G. In: KHOURY, S. Atrás da máscara. RJ: Civilização Brasileira, 1984, p. 27.

${ }^{315}$ GONÇALVES, D. O impetuoso capitão Tic, 10 de novembro de 1955, sem referência ao jornal.
} 
Apesar de não existir referência dos participantes do TPE sobre qualquer deliberação no sentido de uma transposição para a realidade brasileira, é muito provável que essa ideia permeasse o imaginário de todos quando da aceitação da sugestão de Jacobbi. Muitas das imagens de O Impetuoso capitão Tic parecem comparáveis às nossas. Aqui, onde o mundo burguês nunca foi completamente instaurado, último país a abolir a escravidão, não só a relação de favor e do agregado cumpriu papel determinante, como os falsos intelectuais andam ao lado da ordem bruta do militarismo e dos costumes frívolos de uma pequena burguesia. Há muito disso, em chave ainda mais aguda, nos contos de Machado de Assis, tão apreciados, também, por Ruggero Jacobbi.

Apesar dos avanços, não houve grande repercussão pública da peça. E os componentes do TPE acabaram por não lhe atribuir muita importância. Assim como nas montagens anteriores, a peça tematiza aspectos da vida burguesa de maneira critica, com elementos de teatralidade popular. Mas, será essa a impressão posterior, não representavam o ponto de vista da classe trabalhadora.

Diante da insatisfação em relação aos resultados parciais de seus projetos idealizados e percebendo o interesse despertado por seu avanço técnico, acabaram por apostar no caminho da profissionalização e entrar para o Teatro de Arena.

Assim, com relação ao seu plano inicial, o TPE é naquele momento um projeto que não se concretiza, em seus pressupostos de desenvolvimento radical da condição amadora. A síntese entre um projeto estético-político nacional popular e engajamento na transformação da realidade brasileira não encontra os meios necessários para a superação das dificuldades dadas pela própria situação pioneira. No entanto, aquele núcleo inicial do TPE ao entrar no terreno do teatro profissional não abandonou seus propósitos, bem como não abriu mão da dimensão experimental (e do interesse 
formativo) decorrente do teatro amador, o que acabou por transformar os paradigmas produtivos do novo ambiente em que adentravam e abrir novos caminhos para o teatro brasileiro moderno. 


\section{Capítulo 6}

\section{A FUSÃO COM O TEATRO DE ARENA}

Alguns meses antes da fundação do Teatro Paulista do Estudante, o Teatro de Arena inaugurava sede própria, no dia $1^{\circ}$ de fevereiro de 1955, na Rua Teodoro Bayma, número 94. No final de 1954, após um ano de trabalho sem sede fixa, José Renato finalmente havia alugado um "armazém vazio empoeirado", "fechado em 1950",316 que ficava perto de sua casa.

A mudança para sua própria sede veio representar, inevitavelmente, a perda da mobilidade. Apesar disso, a ideia de atingir públicos de outras classes sociais havia sido uma das necessidades sentidas desde o início, e não desapareceria da pauta interna de discussões do Arena $^{317}$.

No dia da estreia, Ruggero Jacobbi ${ }^{318}$ fez uma fala, antes da abertura, em que ressaltava a importância da inauguração daquela sede para a consolidação de uma cultura teatral em São Paulo. A peça de estreia foi A Rosa dos Ventos, de Claude Spaack, traduzida por Esther Mesquista. Uma peça de jogo psicológico:

\footnotetext{
${ }^{316}$ PÉCORA, J. R. Coleção Ciclo de Palestras sobre o Teatro Brasileiro, 4. Rio de Janeiro: INACEN, 1987, p. 8.

${ }^{317}$ BETTI, M. S. A politização do teatro: do Arena ao CPC. In: FARIA, J. R. (Org.). História do teatro brasileiro 2. São Paulo: Editora Perspectiva e SESC/SP, 2013, p. 176.

${ }^{318}$ Jacobbi foi professor de José Renato na Escola de Arte Dramática (Ruggero foi responsável pelo curso de Interpretação e História do Teatro na Escola de Artes Dramáticas de 1949 a 1951) e o considerava como um "esplêndido talento como diretor e autor", uma grande promessa (JACOBBI, R. Os Meninos, Folha da Noite, São Paulo, 6.7.1953. In: Crítica da razão teatral. São Paulo: Perspectiva, 2005).
} 
A rosa dos ventos é uma tese de possibilidades: o autor por meio de várias hipóteses, procura demonstrar que caminhos poderia ter a vida de Inez e Luiz, o casal de apaixonados ${ }^{319}$

A trama é toda feita de hipóteses imaginadas. Em três atos e nove quadros, o autor apresenta diversas hipóteses do que aconteceria com a relação e a vida do casal, caso Luiz partisse para Paris, "atraído pela sua vocação ou arrastado pela ambição",320 ou se ficasse em sua cidade, Longville, com Inês, mulher que amava. O único quadro da trama cuja ação se dava no plano da realidade era a última. De acordo com José Renato, no programa, a peça partia da premissa de que:

O homem, por si, por mais que se iluda, jamais consegue escolher coisa alguma. A inexorável marcha do tempo de sua direção já está marcada; nada mais faz o homem, do que preencher as lacunas de sua vida com a ilusão de que é ele que se conduz ${ }^{321}$.

Ainda na Escola de Arte Dramática, em 1950, o professor Décio de Almeida Prado lhe apresentou um livro, de uma norte-americana, Margot Jones, que narrava a experiência com o teatro em espaço arena, em 1940.

Foi Décio de Almeida Prado quem me deu um livro de Margot Jones para ler, Theatre in the round, onde ela relata a experiência feita em Dallas [...]. Com este livro na mão, a gente discutia as experiências dela. E resolvemos fazer algo semelhante na EAD, baseados também

\footnotetext{
${ }^{319}$ Programa da peça A Rosa dos Ventos, de Claude Spaack, tradução de Esther Mesquita. Direção: José Renato. Elenco: Raquel Moacyr, Renata Blaustein, Fábio Cardoso, Joselita Alvarenga. Estreia: dia $1^{\circ}$ Fevereiro de 1955.

${ }^{320}$ Programa da peça A Rosa dos Ventos.

${ }^{321}$ Programa da peça A Rosa dos Ventos.
} 
no princípio de que um espetáculo de arena deveria custar aproximadamente $10 \%$ do que custaria em teatro normal ${ }^{322}$.

José Renato realiza na EAD algumas tentativas nesse sentido. Apoiando-se, inclusive, de início, em repertório explorado por Margot Jones para as experiências em arena. A primeira peça encenada nesse modelo em arena foi $O$ demorado adeus, peça em um ato, de Tennessee Williams, em 1951 na EAD. Narra a história de um escritor que vai se mudar do apartamento onde viveu toda a sua vida. Enquanto os carregadores entram e saem do apartamento, retirando os móveis, o jovem trava diálogos imaginários com pessoas do seu passado, que se configuram em cena, pela memória. Não há ação dramática propriamente, há uma longa espera e um personagem em luta psicológica consigo próprio. A iluminação ganha uma importância maior do que o estabelecimento de cenários, o que se revela um bom recurso para um palco em arena, onde muitos objetos podem ser um obstáculo para a visão do público. A experiência com $O$ demorado adeus se tornaria emblemática para a decisão de se formar uma companhia profissional baseada no espaço arena ${ }^{323}$.

É peculiar que os primeiros formandos da EAD, "que tinha sido criada para fornecer sangue novo ao TBC"324, sejam aqueles que provavelmente inauguraram no Brasil o modelo em arena, cuja redução de custos e flexibilidade em relação ao teatro convencional é evidente. Em entrevista a Fernando Peixoto, Guarnieri sugere que a opção desses jovens se deu por "uma compreensão realista da situação daquele momento", uma vez que desde fins de 1952 o TBC enfrentava uma insolúvel crise financeira. Nas suas palavras:

\footnotetext{
${ }^{322}$ PÉCORA, J. R. Op. Cit., p. 8.

${ }^{323}$ Id. Ibid., p. 9. O teatro de Arena é apresentado por Décio de Almeida Prado, José Renato e Geraldo Mateus como uma solução para falta de teatros na cidade. A tese foi apresentada em julho de 1951, no I Congresso Brasileiro de Teatro, realizado no Rio de Janeiro, p. 30. Ver também PRADO, D. A. Teatro brasileiro moderno. 3ed. São Paulo: Perspectiva 2009, p. 62.

${ }^{324}$ GUARNIERI, G. Apud PEIXOTO, Teatro em Movimento. São Paulo: Hucitec, 1989, p. 47.
} 
Escolheram a forma circular como resultado de uma constatação, por necessidade de produção: sem cenários, montagens mais baratas, possibilidade de fazer espetáculos em diversos locais ${ }^{325}$.

As primeiras apresentações com elenco profissional foram feitas no Museu de Arte Moderna de São Paulo. A estreia do grupo foi a peça do inglês Stafford Dickens, Essa noite é nossa, no dia 11 de abril de 1953. Ruggero Jacobbi, na crítica sobre a estreia ressaltou a novidade produtiva do espaço em arena:

O teatro de arena, tão facilmente desmontável, tão facilmente adaptável a qualquer sala, permite aos clubes, às associações, às famílias, às cidades que não possuem teatro, a realização de ótimos espetáculos dentro de orçamentos suportáveis tanto para tais entidades como para o próprio grupo teatral ${ }^{326}$.

Em relação à peça, Jacobbi, ressalta seu caráter despretensioso, marcada por diálogos “inocentes" e "divertidos", lembrando peças de boulevard" ${ }^{327}$. No entanto, o comentário de Ruggero, em outra crítica publicada três dias depois, revela, com sua elegância, certo desajuste entre a escolha de repertório e as possibilidades formais, a partir do modelo em arena. Em comparação com a pesquisa que José Renato vinha fazendo com $O$ demorado adeus ${ }^{328}$, Jacobbi comenta:

\footnotetext{
${ }^{325}$ Id. Ibid., p. 47.

326 JACOBBI, Ruggero. Essa noite é nossa. Folha da Noite, São Paulo. Segunda feira, 14.4.1953, primeiro caderno, p. 7.

${ }^{327}$ Id. Ibid., p. 7.

${ }^{328}$ No dia primeiro de agosto de 1953 o Teatro de Arena estreou, agora profissionalmente, O demorado adeus, no Museu de Arte Moderna. José Renato, no entanto, em depoimento de 1987, considerou que foi com a apresentação de Uma mulher e três palhaços, estreada no dia primeiro de abril de 1954, que eles
} 
Compreendemos perfeitamente que a peça, pela sua natureza de comédia burguesa, não permitia grandes achados, ou mesmo que os permitisse, acabaria tornando-os desproporcionais à substância. Por isso ficamos à espera do dia em que José Renato poderá aplicar seus estudos sobre a técnica do teatro de arena a um texto mais resistente ${ }^{329}$.

O repertório do Arena desde seu nascimento até a fusão com integrantes do TPE pouco diferia do que vinha sendo armado no TBC, “comédias leves que garantam a bilheteria [...] e, para satisfazer, vez por outra, uma parcela de público mais exigente, peças de pretensão genericamente cultural ${ }^{\natural 33}$. Um repertório eclético, alternando entre nacionais e estrangeiro.

A crítica, nas primeiras experiências do Teatro de Arena "registra as dificuldades de adaptação à arena",331. A companhia não estava confortável com a proximidade tão grande com o público e procurou criar substitutos, como vãos de paredes e janelas, que marcavam uma separação entre espaços na cena e entre a cena e o público, como uma "quarta parede":

A cena volta-se para dentro, para si mesma, e os atores se isolam da plateia como que por paredes de vidro, numa encenação que se assemelha a movimentos dentro de um grande aquário ${ }^{332}$.

pela primeira vez encontraram "uma linguagem cênica em que a forma de arena era aplicada com mais propriedade" (PÉCORA, J. R. Op. Cit., p. 9).

329 JACOBBI, Ruggero. Seis moços, seis talentos. Folha da Noite, São Paulo, terça feira, 18.04.1953, segundo caderno, p. 3

${ }^{330}$ CAMPOS, C. A. Zumbi Tiradentes. São Paulo: Editora Perspectiva, 1988, p. 33.

${ }^{331}$ Id. Ibid., p. 32.

${ }^{332}$ Id. Ibid., p. 32. 
É possível que esse “descolamento" inicial entre a exigência formal imposta pelo novo espaço e as intenções iniciais de conservar o mesmo mecanismo criado pelo TBC, tenha ocorrido porque a necessidade econômica de adaptar os aparatos cênicos e o espaço veio antes da inquietação por uma reformulação do modelo de modernização vigente. Ainda assim, mesmo aquelas primeiras experiências do Arena não se confundiam com o modelo empresarial do TBC. A forma circular, a nudez da cena, mesmo sem um projeto cultural definido provavelmente forçaria a reformulação de seu uso, uma vez que o espaço arena limitava a ideia de "peça bem feita". O espaço por ser muito pequeno e por obrigar uma proximidade entre atores e público exigiria um tipo de atuação mais sóbria e intimista, mais realista. Segundo Flávio Migliaccio, se referindo a um momento posterior do grupo:

Antes o teatro era muito impostado, o pessoal falava com uma voz impostada, que tinha ter uma boa voz, tinha que saber sentar, tinha que saber fazer tudo e de uma maneira muito digna. A gente, no Teatro de Arena foi obrigado a fazer uma coisa mais realista. O teatro de arena como era muito pequeno, de 155 lugares, o espectador ficava a um metro e meio de distância, a gente não podia falar muito alto, a gente tinha que falar de uma maneira mais coloquial, ter uma interpretação mais coloquial ${ }^{333}$.

O próprio interesse que José Renato manifestou pelos militantes comunistas do Teatro Paulista do Estudante é um indicador de sua abertura, ainda que não consciente, às novas ideias e modos de produção.

\footnotetext{
${ }^{333}$ Entrevista com Flávio Migliaccio realizada dia 14.07.2015
} 
Foi Ruggero Jacobbi quem apresentou ao José Renato o pessoal do Teatro

Paulista do Estudante e lhe pediu que permitisse ao grupo amador ensaiar no espaço ${ }^{334}$. Inicialmente, o acordo previa apenas uma troca, o TPE cederia atores para figuração ${ }^{335} \mathrm{e}$ o Arena emprestava o espaço para ensaios e estreias do grupo estudantil, às segundas feiras.

Acordo de fusão entre o Teatro de Arena e o Teatro Paulista do Estudante

Em junho de 1956, apenas um ano após a fundação do TPE e da parceria com o Arena, ocorre uma fusão real entre os atores do TPE com o Núcleo Permanente do Teatro de Arena.

A síntese do novo acordo foi publicada em 1956 nos programas das peças Dias Felizes e Essas Mulheres. Já o documento completo com os termos de acordo $^{336}$ tem quatro folhas, com cinco grandes tópicos e 44 itens, listando os objetivos do acordo, questões de organização, direitos e deveres do TPE na nova formação do Teatro de Arena. Os tópicos especificam o tipo de ajuda mútua que o grupo profissional e o grupo amador cultivariam. Apesar da fusão, o TPE manteria sua autonomia, podendo,

\footnotetext{
${ }^{334}$ Segundo José Renato: "Ruggero Jacobbi foi outro mentor. Era o intelectual mais desenvolvido deles todos, um grande filósofo, grande professor, um homem que trouxe enorme contribuição para o teatro brasileiro. As análises que ele fazia dos textos, a preparação intelectual que ele demonstrava, eram as mais notáveis. A inteligência e o brilho eram impressionantes, em dois ou três meses já falava português como qualquer brasileiro. Foi a melhor contribuição dos italianos ao desenvolvimento do nosso teatro, na época. Chegou a escrever críticas nos jornais e revistas. Foi ele que, anos mais tarde, me apresentou o Teatro Paulista do Estudante para integrar o Grupo do Arena" (PÉCORA, José Renado Apud BASB AUM, H. José Renato energia eterna. São Paulo: Imprensa Oficial, 2009, p. 34).

${ }_{335}$ Alguns jovens do TPE foram elenco de apoio do espetáculo Escola de Maridos, de Moliére, em fevereiro de 1956. Gianfrancesco Guarnieri, no papel de Ergasto; Oduvaldo Vianna Filho, como "Lácio da lanterna"; Milton Leandro e Leonardo Fernandes como "homens do povo". Programa da peça Escola de Maridos, direção José Renato. Estreia: $1^{\circ}$ Fevereiro de 1956, Teatro de Arena.

${ }_{336}$ Termos de Acordo entre o Teatro de Arena e o Teatro Paulista do Estudante, documento cedido por Vanya Sant’Anna, viúva de Gianfrancesco Guarnieri (Ver Anexo).
} 
inclusive optar por não participar de montagens do Teatro de Arena, caso discordasse do “conteúdo político-partidário ou religioso",337.

Como objetivos da fusão estão a ideia de ampliação do elenco permanente do Teatro de Arena e o empenho na criação de um teatro nacional e popular. A fusão implicaria no engajamento pela

formação de um movimento teatral de apoio às obras e autores nacionais, bem como de divulgação teórica e prática das coisas de teatro. [...] Divulgação da arte cênica em fábricas, escolas e cidades do interior do Estado 338 .

Esses objetivos são, em alguma medida, uma reedição daqueles expressos na tese que o TPE divulgou no II Congresso e na entrevista que concederam à Revista de Teatro Amador. Percebe-se que as condições que eles imprimem para o ingresso na vida profissional estão ligadas à continuidade de um projeto de refuncionalização do teatro, que previam para o amadorismo.

Os integrantes do TPE faziam questão de manter a autonomia de ação e o vínculo com entidades estudantis, com o teatro amador. No tópico Organização é sublinhado, por exemplo, que nos programas das peças "cada nome dos componentes do TPE" precisaria constar com as iniciais "TPE, bem como um histórico do mesmo e uma síntese do [...] acordo". A mesma coisa com a ideia de que o elenco do TPE somente poderia participar de viagens ao interior do estado nos finais de semana, “durante o período letivo", pois afinal eram eles estudantes e não profissionais do teatro.

\footnotetext{
${ }^{337}$ Termos de Acordo entre o Teatro de Arena e o Teatro Paulista do Estudante (ver anexo).

${ }^{338}$ Termos de Acordo entre o Teatro de Arena e o Teatro Paulista do Estudante (ver anexo).
} 
E ainda deveriam ser poupados de tarefas teatrais durantes os meses de exame nas escolas e universidades ${ }^{339}$. Nesse sentido:

Será dado ao TPE, como entidade, o encargo da organização de palestras, debates, mesas-redondas etc., que serão realizados no T.A [Teatro de Arena] e constituirão o trabalho de difusão teórica; Ambas as entidades não perderão sua autonomia, funcionando suas direções normalmente; o elenco permanente será obrigado a dar espetáculos em fábricas, escolas, clubes etc., a preço de custo, ficando tais espetáculos limitados ao número de 05 por mês; [...] As duas entidades manterão um sistema de trabalho baseado no apoio mútuo, comunicando uma a outra seus planos extraprogramação comum ${ }^{340}$.

A necessidade de explicitar que o elenco permanente do Teatro de Arena é composto em parte por elementos do grupo amador traduzem, de certa forma, a ideia que o TPE tinha para viabilizar um projeto de sentido nacional com perspectiva popular para o teatro, que dependeria de uma verdadeira união entre amadores e profissionais, aproveitando as vantagens de cada tipo. Poderiam sustentar atividades paralelas, com a direção autônoma entre as partes, mas em constante diálogo e parceria. O acordo era o início de um verdadeiro programa de reformulação da prática teatral, de ampliação do público, com perspectivas de formação e aproximação de parcelas estudantis, conjugando esforços em diversas frentes de trabalho.

Para aproximar o público estudante - e os grupos amadores - fazia parte do acordo que cada espetáculo tivesse uma apresentação extra, que seria oferecido

\footnotetext{
${ }^{339}$ Termos de Acordo entre o Teatro de Arena e o Teatro Paulista do Estudante (ver anexo).

${ }^{340}$ Termos de Acordo entre o Teatro de Arena e o Teatro Paulista do Estudante (ver anexo).
} 
gratuitamente aos sócios do TPE e a preços populares para estudantes em geral. Tal medida também já aparecia claramente naquela tese divulgada no II Congresso.

Apesar de compor o elenco permanente, o TPE não recebia, no inicio, como os atores do elenco profissional. Recebia enquanto grupo o valor de treze mil cruzeiros. Isso justamente porque não eram profissionais. E ainda receberia " $10 \%$ do montante das mensalidades pagas pelos sócios do TA [Teatro de Arena]". E mais uma porcentagem da venda de espetáculos que eles próprios fizessem na Capital e no interior.

Guarnieri sugere que já naquele primeiro momento José Renato talvez pressentisse que o caminho para a realização de um grupo estável como ele desejava estivesse mais na aproximação com o pessoal do TPE do que com o elenco que ele havia formado inicialmente, com atores oriundos da Escola de Arte Dramática ${ }^{341}$. Não havia um fundamento programático que unisse inicialmente os atores do Teatro de Arena. Tratava-se mais, como visto, de uma necessidade de criar novas condições de trabalho para os novos profissionais, que vinham se formando, por exemplo, pela Escola de Artes Dramáticas. Então, segundo Guarnieri:

O Teatro de Arena absorveu a primeira turma de atores que se formou na EAD - Escola de Arte Dramática, mas o Zé Renato sentiu que não iria conseguir segurar o pessoal, não iria conseguir que o grupo permanecesse junto. Então ele sacou, conseguiu vislumbrar uma possibilidade de continuidade de trabalho com a turma do TPE, que estava dando sopa $[\ldots]^{342}$

Já o interesse do TPE pelo Teatro de Arena se deu antes de tudo pelas condições materiais e estruturais de criação e produção. Desde a primeira montagem havia um

${ }^{341}$ GUARNIERI, G. In: KHOURY, S. Atrás da máscara. Rio de Janeiro: Civilização Brasileira, 1984.

${ }^{342}$ Id. Ibid., p. 29. 
acordo com o grupo profissional e em determinado momento optaram por atrelar mais definitivamente os projetos. E viam ali a possibilidade de colocar em prática o plano de trabalho pelo qual vinham batalhando. Segundo Guarnieri, em entrevista para Fernando Peixoto, enxergavam a chance de uma atuação em termos "de igualdade e não de absorção" pelo grupo estável e profissional.

\begin{abstract}
A gente queria se manter fiel a determinadas ideias. O Vianinha e eu, por exemplo, estávamos recebendo convites para entrarmos profissionalmente em outras companhias, TBC, Sérgio Cardoso etc. A gente não entrou não só por fidelidade ao TPE, mas também porque o trabalho que nos ofereciam nos levaria a abrir mão de toda uma série de valores. [...] A gente confiava no Arena, no José Renato, que dirigia o Arena desde o início, não só achava, como tinha indícios, de que o pessoal do Arena estava bem próximo da nossa proposta ${ }^{343}$.
\end{abstract}

De todo modo, a aproximação com o Teatro de Arena transformou os rumos deste, como enuncia Zé Renato:

foi sem dúvida a presença do Teatro Paulista de Estudante que, por assim dizer, trouxe a semente do engajamento que germinou aqui dentro e deu, acredito, os melhores frutos possíveis ${ }^{344}$.

Guarnieri em entrevista a Fernando Peixoto comenta que a fusão:

\footnotetext{
${ }^{343}$ GUARNIERI, G. In: PEIXOTO, F. Teatro em Movimento. São Paulo: Hucitec, 1989, p. 49.

${ }^{344}$ PÉCORA, J. R. Op. Cit., 1987, p. 22.
} 
deu origem a um novo grupo, já que o Arena se havia modificado, com a nossa entrada. $\mathrm{O}$ que existia já não eram mais nem o antigo TPE nem o antigo Arena. Houve injeção de espírito novo de trabalho, de inquietação, trazido pela gente que vinha do movimento estudantil, que vinha de lutas concretas ${ }^{345}$.

Essa iniciativa foi amplamente aplaudida por profissionais e amadores. Hermilo Borba Filho, por exemplo, em artigo de jornal, de março de 1956, felicita o acordo do Teatro de Arena com o Teatro Paulista do Estudante entendendo que o gesto significava:

a união de forças para criar um amplo movimento teatral de apoio e incentivo às obras nacionais. Os dois elencos reunidos pretendem levar o teatro às mais diversas camadas da população bem como realizar palestras, cursos e conferências sobre problemas do teatro ${ }^{346}$.

Também a Federação Paulista de Teatro Amador via no acordo a possibilidade de realizar aqueles objetivos levantados pelo TPE no II Congresso de Teatro, em setembro do ano anterior. Em pequeno artigo para a importante revista Teatro Brasileiro, de abril de 1956, J. E. Coelho Neto faz uma nota sobre a fusão. O TPE, que segundo este artigo, estaria responsável pelo departamento de Teatro Estudantil da Federação, a partir desse intercâmbio teria mais condições de fomentar o teatro enquanto cultura:

\footnotetext{
${ }^{345}$ PEIXOTO, F. Teatro em Movimento. São Paulo: Hucitec, 1989, p. 49.

${ }^{346}$ BORBA Filho, Hermilo. Unem-se artistas do teatro de Arena e do TPE. O Estado de S. Paulo. Março de 1956. Documento datilografado, cedido por Vanya Sant'Anna, do arquivo de Gianfrancesco Guarnieri.
} 
Possibilitará a execução de um vasto plano de expansão do teatro, como cultura e como arte entre esta grande classe de estudantes que formará em futuro próximo a vanguarda da nossa vida intelectual ${ }^{347}$.

Isto indica que talvez já estivessem lançadas as prerrogativas para uma transformação funcional e produtiva no teatro brasileiro, existia uma expectativa nesse sentido a partir da fusão dos dois grupos.

Todavia, as primeiras peças que o TPE participa junto ao Arena, seja como elenco de apoio ou já como segundo elenco estável, não refletiam o desejo de atuação manifesto na síntese do acordo entre os grupos. O repertório ainda era marcado por um "ecletismo", sem um direcionamento programático de pesquisa, que seria a novidade e grande força do Teatro de Arena a partir de 1958. Em junho de 1956 estreiam duas peças com diferença de 16 dias, colocando em prática a ideia de dois elencos permanentes, o do TPE e o profissional do Arena. O elenco do TPE estreia a peça Dias Felizes, de Claude Puget, com direção de José Renato ${ }^{348}$. Maria Jacintha, antiga colaboradora do Teatro do Estudante do Brasil de Paschoal Carlos Magno havia feito uma adaptação para ambiente brasileiro dessa comédia fazendo-a se passar em Campinas e modificando os nomes para nomes mais brasileiros. Antes de estrearem na sede da Rua Teodoro Bayma, o Teatro de Arena havia levado essa montagem para Mococa, em 17 de abril de $1956^{349}$. O elenco profissional do Arena, por sua vez, apresentou Essas Mulheres, de Regnier, com direção também de José Renato ${ }^{350}$.

\footnotetext{
${ }^{347}$ COELHO, J. E. Os amadores em São Paulo. Revista Teatro Brasileiro, nº 6, São Paulo, 1956, p. 7.

${ }^{348}$ Programa de Dias Felizes, direção de José Renato. Estreia: 05 de junho 1956. Texto de Claude Puget, tradução de Maria Jacintha e Esther Mesquita. Elenco: Mea Marques; Alzira Mattar; Vera Gertel; Gianfrancesco Guarnieri; Oduvaldo Vianna Filho e Raul Cortez.

${ }^{349}$ Documento datilografado, cedido por Vanya Sant'Anna. Nele aparecem os nomes de Beatriz Segall como assistente de direção e Sérgio Rosa e Flávio Migliaccio como diretores de Cena.

350 Programa Essas Mulheres, direção José Renato. Estreia 21 de junho de 1956. Texto: Regnier. Tradução: José Renato; Elenco: Fausto Fuser; Marina Freire Franco; Nello Pinheiro; Floramy Pinheiro; Salomão Guz; Luiz Eugênio Barcelos.
} 
Guarnieri justifica a incerteza do repertório nos primeiros momentos da fusão com o Arena, um pouco pela relação que se firmava entre eles, pelo fato de não serem completamente integrados ao Arena, de não fazerem parte da decisão de escolhas da peças e de não serem pagos como atores profissionais do grupo.

De qualquer maneira, segundo Maria Silvia Betti:

O acordo se mostrou decisivo para o destino de ambos os grupos: o ingresso nos espetáculos profissionais do Arena levou alguns dos principais integrantes do TPE [...] a se profissionalizarem no teatro: o Arena, por outro lado, com o ingresso de atores provindos da militância estudantil, passaria a reunir as condições determinantes para sua politização ${ }^{351}$.

Entre amadores e profissionais

O TPE fez questão de levar para dentro do profissionalismo do Teatro de Arena os compromissos que assumiram enquanto grupo amador e o engajamento político. Isso, aliado às circunstâncias produtivas da constituição do Teatro de Arena, fizeram com que houvesse uma nova conjunção de forças, que combinava aspectos do amadorismo e do profissionalismo. O que em breve resultaria naquilo que Ruggero Jacobbi previa, em 1952:

\footnotetext{
${ }^{351}$ BETTI, M. S. A politização do teatro: do Arena ao CPC. In: FARIA, J. R. (Org.). História do teatro brasileiro 2. São Paulo: Editora Perspectiva e SESC/SP, 2013, p. 177.
} 
Os grupos de amadores continuam produzindo, a cada dia, valores novos, gente que, se não se perder, poderá fornecer ao teatro brasileiro um verdadeiro exército de forças inesperadas ${ }^{352}$

Os amadores, não tendo fins comerciais, poderiam "manter viva a chama de uma concepção de teatro como cultura e como arte"353. Deveriam trabalhar como equipe, sem vaidades, com “empreendimentos ousados" e "caráter experimental"354.

O TPE procurou levar para sua profissionalização, junto ao Teatro de Arena, iniciativas que facilitassem o acesso ao teatro e incentivos à participação de um público mais jovem. Esse processo já estava sendo iniciado pelo próprio Teatro de Arena. Mas o TPE procurou reforçar os vínculos com as entidades amadoras, como a Federação Paulista de Teatro Amador, e o público estudantil, com popularização dos preços da bilheteria, cursos de teatro destinados aos estudantes etc. O resultado disso foi uma gradativa alteração do público frequentador do Teatro de Arena, que passou a ser predominantemente de estudantes secundaristas e universitários.

A fusão com o Teatro de Arena não alterou, porém, a questão do financiamento. Por mais esquerdizantes que tenham sido as propostas do Teatro de Arena, ele não deixou de funcionar basicamente como uma empresa, dependendo da bilheteria para sobrevivência. Sempre houve esta tensão pelo preço dos aluguéis das salas e os custos das bilheterias. Também a briga por verbas do Estado, que instáveis e submetidas às condições políticas sempre oscilaram na participação do desenvolvimento da cultura.

E mesmo enquanto ainda grupo amador, o TPE teve de enfrentar a questão do financiamento para continuidade de seus projetos. Desde o início eles viveram a tensão da subsistência, de como viabilizar o projeto idealizado. Para conseguir financiamento

352 JACOBBI, R. Crise do Teatro, Teatro da Crise, Folha da Noite, São Paulo, 4.11.1952. In: Crítica da razão teatral. São Paulo: Perspectiva, 2005, p. 4.

${ }^{353}$ JACOBBI, R. Crítica e indulgência, Folha da Noite, São Paulo, 22.11.1952. In: ${ }^{354}$ Id. Ibid., p. 5. Op. Cit., p. 4. 
para o grupo - segundo os depoimentos - o Teatro Paulista do Estudante aceitava apresentar peças em qualquer lugar e circunstâncias - como a participação em programas de talentos - e chegaram a pedir dinheiro na rua, de acordo com o depoimento de Flávio Migliaccio.

Esta questão acompanhou o grupo e parece ter sido motivo de muita reflexão e crise. Para conseguir produzir, participaram de festivais competitivos e realizaram $A$ Noite de Arlequim, um evento para promover o grupo e aproximar possíveis colaboradores associados. Mas essas mesmas práticas se por um lado os aproximava do meio artístico por outro não resolviam a precariedade financeira. A ideia de se aliarem a setores organizados dos trabalhadores surgiu desde a primeira montagem, de A Rua da Igreja, mas não pôde ir adiante.

O Teatro de Arena ao se definir como uma empresa (com orientação de esquerda) incorporou o amadorismo sem absorvê-lo por completo na estrutura profissional. Conseguiu inaugurar um tipo de organização interna que até então não existia nos grupos profissionais, um trabalho efetivamente de equipe. E o Teatro Paulista do Estudante trouxe desde sua fundação, a partir do imaginário comunista e da influência de Jacobbi, a ideia de um teatro com vínculo social, que se propusesse a olhar para a realidade do mundo do trabalho, dos homens.

Entretanto, foi só a partir da chegada de Augusto Boal, ao Teatro de Arena, em meados de 1956, que efetivamente se formam as condições para a criação de um novo modo de fazer teatral. É partir, dessa tríade fundamental - TPE, Arena e Boal - que ocorre o início de uma profunda transformação no teatro brasileiro. 
De acordo com Vianinha, em Do Arena ao CPC, um texto crítico ao grupo, o Arena, com a chegada de Augusto Boal, teve condições concretas de realizar um teatro que procurasse refletir sobre as condições históricas brasileiras:

Deixou de haver funções estanques de ator, diretor, iluminador etc. $\mathrm{O}$ Arena tornou-se equipe, não no sentido amistoso do termo [...] mas no sentido criador. [...] Boal mobilizou toda a imensa capacidade ociosa existente; Flávio Migliaccio, que só fazia pontas e carregava material de contra-regragem, praticamente inventou um novo ator no Brasil $[\ldots]^{355}$.

José Renato queria alguém que pudesse dividir a direção com ele e pediu indicação a Sábato Magaldi ${ }^{356}$. De acordo com Guarnieri, o Zé Renato contratou Boal "sem pestanejar" e sem consultar o restante do elenco:

Ele tomou essa atitude sob protesto geral porque para nós ele não era Augusto Boal e sim “Ôgast Bôuall”, ele era um cara "colonizado", um norte-americano (risos), e nós estrilamos: "Porra! Vão trazer um americano para nos dirigir!" "Essa, não” Vamos entrar numa fria, não pode ser." Nós não conhecíamos nada do Boal, e o contrato dele com o Arena foi um negócio assim meio escondido, meio debaixo do pano. Quando se marcou o primeiro encontro entre nós, já estávamos

355 VIANNA Filho, Oduvaldo. Do Arena ao CPC, Revista Movimento $\mathrm{n}^{\mathrm{o}}$ 6, outubro de 1962. In: PEIXOTO, Fernando (Org.). Vianinha (Teatro, televisão, política). São Paulo: Brasiliense, 1983, p. 92.

${ }^{356}$ PÉCORA, J. R. Op. Cit., 1987, p. 13. 
preparados para hostilizar o "gringo", quando de repente nos aparece um cara simpaticão, meio desengonçado, com um tremendo sotaque carioca... e nos entendemos às mil maravilhas logo de cara ${ }^{357}$.

A reação inicial do núcleo do TPE foi reveladora do desejo de dar vez a um projeto nacional. Os diretores estrangeiros representavam o universo de modernização ligado ao TBC, a que esses jovens começavam a se contrapor. E os Estados Unidos eram a representação máxima do imperialismo e colonialismo a ser superado em prol de uma soberania nacional.

Mas assim que conhecem Augusto Boal os preconceitos são desfeitos e há um imediato entrosamento entre as ideias do elenco jovem (TPE) com as novidades de trabalho trazidos por Boal de sua experiência nos Estados Unidos. Para Flávio Migliaccio, Boal foi o elo final da fusão entre TPE e Arena:

A gente sabia que precisava daquilo, precisava do Boal. E o Boal precisava da gente. Não teve conflito nenhum. Foi muito bom! Uma coisa perfeita, uma coisa que veio complementar o TPE, o Arena, essa união entre os dois ${ }^{358}$.

É bem provável que a afinidade imediata que Boal sentiu com os rapazes do TPE tivesse muito mais a ver, naquele primeiro momento, com o frescor do elenco jovem, não impregnado pelos "vícios" de atuação das escolas de artes dramáticas e do TBC, cuja interpretação Boal considerava "estilizada", do que por identificação política. Boal acabara de voltar dos Estados Unidos, onde estudou com o crítico e professor John Gassner e por sua influência pode frequentar por um período de tempo o Actor's Studio,

\footnotetext{
${ }^{357}$ GUARNIERI, G. In: KHOURY, S. Op. Cit., 1983, p. 33.

${ }^{358}$ Entrevista com Flávio Migliaccio dia 14.07.2015
} 
cuja direção estava a cargo de Lee Strasberg. Voltou ao Brasil disposto a colocar em prática tudo aquilo que havia observado e aprendido. Ele provavelmente viu naqueles jovens praticamente inexperientes, sem as "marcas" do teatro profissional, uma ótima oportunidade para “experimentar” as novas técnicas de interpretação.

Foi com a chegada de Boal ao Teatro de Arena que na prática os atores do TPE foram incorporados ao elenco principal ${ }^{359}$, passaram a receber de maneira igual e foi então, portanto, que efetivamente se profissionalizaram. Foram convocados novos atores, como Milton Gonçalves ${ }^{360}$ e José Serber, e atores da velha guarda, como Sadi Cabral. A ideia era poder apresentar pelo menos duas peças quase simultaneamente ${ }^{361}$.

É também a partir da chegada de Boal que as ideias dos cursos práticos, divulgados no acordo de fusão tornam-se realidade. Primeiro, durante os ensaios de Ratos e homens, Boal inicia um "Curso prático de dramaturgia" e o Arena promove um concurso para adaptações de conto (o premiado teria sua peça apresentada na Casa do Povo). E em junho de 1957, no Programa de Juno e o pavão, é anunciada a primeira de uma série de palestras que o TPE organizaria no Teatro de Arena, ainda como resultado do acordo. O curso foi oferecido pelo TPE em associação com a Federação Paulista de Teatro e foi composto de "quatro aulas semanais (terça e sexta) durante 26 semanas

\footnotetext{
${ }^{359}$ PÉCORA, J. R. Op. Cit., p. 13.

${ }^{360}$ A estreia de Milton Gonçalves no Teatro de Arena foi em Ratos e homens. Ele era de uma família pobre, trabalhava numa gráfica e fazia teatro amador com Egídio Écio e a Maria Edith. Apresentaram uma peça, $O$ Príncipe Lenhador, no Teatro Colombo, em que ele se pintava todo de branco para fazer o papel de um rei. Ali conheceu Sérgio Rosa, que mais tarde lembrou-se dele e o convidou para o elenco de Ratos e homens. (Entrevista com Milton Gonçalves para esta pesquisa, Rio de Janeiro, dia 15 de julho de 2015).

${ }^{361}$ Ratos e homens estreia em setembro e no dia 14 de outubro estreava o teatro infantil do Teatro de Arena, dirigido por Fausto Fuser, com O rapto das cebolinhas, de Maria Clara Machado. No elenco estavam: Méa Marques, Leonardo Fernandes, Oduvaldo Vianna Filho, José Sales, Vera Gertel, Romeu Prisco, Joyce Beraldi e Paulo Paturalski. E em janeiro de 1957 estreou Marido magro, mulher chata, de Augusto Boal, direção de Augusto Boal. Elenco: Oduvaldo Vianna, Mariúsa Vianna, Riva Nimits, Geraldo Ferraz, Hernê Leblon.
} 
seguidas, divididas em dois períodos" ${ }^{362}$. De acordo com Guarnieri, passaram mais de duzentas pessoas nesses cursos.

Um novo sistema de trabalho no Teatro de Arena

Ratos e homens, de John Steinbeck, foi a peça escolhida para a união da "tríade" (Zé Renato, TPE e Boal) e realmente foi a pedra angular para um novo modo de produção dentro do Teatro de Arena. Estreou no dia 26 de Setembro de 1956, com Guarnieri e José Serber nos papéis principais ${ }^{363}$.

Em seu livro de memórias, Boal conta que sua ideia inicial era encenar Hamlet, mas recua diante das incertezas sobre a possibilidade de adaptação de Shakespeare para um espaço fechado e pequeno. Para Boal, Hamlet precisava de lugar aberto e o espaço na Rua Teodoro Bayma, "pouco maior que uma [sala] de jantar ${ }^{364 »,}$, era completamente oposto a ideia de "céu aberto", de lugar amplo. "Arena era olho no olho, close-up"365. Chegou à conclusão de que era possível encenar Shakespeare assim, mas optou, naquele momento, por outro caminho, por Ratos e Homens, de Steinbeck ${ }^{366}$.

Essa pobreza não desejada acabou se transformando em condição ideal para o trabalho com atores. Espaço cênico finito: dentro de

\footnotetext{
${ }^{362}$ Programa Juno e o Pavão (de Sean O’Casei, direção de Augusto Boal. Elenco: Sadi Cabral, Oduvaldo Vianna, Esther Guimarães, Riva Nimitz. Estreia: 05 de junho de 1957).

${ }^{363}$ Programa de Ratos e homens, de John Steinbeck. Direção: Augusto Boal. Elenco: Gianfrancesco Guarnieri no papel de George, José Serber como Lennie. Além deles haviam: Nilo Odália; Taran Dach; Salomão Guz; Geraldo Ferraz; Riva Nimitz; Nello Pinheiro; Sérgio Rosa; Milton Gonçalves Estreia: 26 de setembro de 1956.

${ }^{364}$ BOAL, A. Hamlet e o filho do padeiro. Rio de Janeiro: Record, 2000, p. 139.

${ }^{365}$ Id. Ibid., p. 139.

${ }^{366}$ Poucos meses depois Augusto Boal encena Juno o pavão, de Sean O’Casey, com Vianinha no papel principal. Vianinha recebeu prêmio Saci de melhor ator por sua interpretação nessa peça
} 
nós, porém, somos infinitos. Fizemos a busca da infinitude para dentro de nós ${ }^{367}$.

John Steinbeck escreveu o romance Of mice and man em 1937 e no mesmo ano fez a adaptação dramatúrgica, para ser encenada na Broadway ${ }^{368}$.

O contexto da peça é o da crise de 1929 na Califórnia. Lá a terra foi usada para agricultura predatória, para alimentar o gado. Muito em decorrência disso, em 1930 ocorreu o Dust Bowl, uma série de tempestades de areia, que duraram cerca de 10 anos e que arrasaram boa parte do sul dos Estados Unidos. Na época cerca de 400 mil trabalhadores rurais tiveram de migrar em busca de trabalho.

A peça trata de uma tragédia ligada à condição miserável dos trabalhadores rurais nos Estados Unidos da década de 30. Na trama, dois migrantes, Lennie e George, buscam um novo trabalho temporário, pois haviam acabado de ser expulsos de um trabalho em outra fazenda. Totalmente na contramão da prática corrente de migrantes solitários, a dupla anda sempre junta: George é fraco e esperto e Lennie é grandalhão e abobalhado. A relação entre os dois - a possibilidade de humanidade - é estabelecida pela condição de interdependência: Lennie é forte e consegue trabalhar muito, mas é bobo e pode ser muito violento; George é fraco e mirrado, não aguenta um trabalho físico intenso, mas é esperto. A dupla central teria algo de especial, que os diferenciava da massa, esse vínculo de dependência e amizade. Eles sonham com a possibilidade de uma nova vida, um futuro melhor, em que teriam o próprio rancho, com vacas e porcos. Seriam seus próprios patrões e poderiam trabalhar apenas seis ou sete horas por dia (até o sonho é ligado ao mundo do trabalho, eles sonham apenas em não terem exploradas

\footnotetext{
${ }^{367}$ BOAL, A. Op. Cit., 2000, p. 139.

368 "A estrutura dramatúrgica se concentrava em aspectos essenciais, ou seja, em diálogos e ações. Para escrever a adaptação, Steinbeck, que não era dramaturgo, procurou aconselhamento técnico com George Kaufman, diretor e autor teatral que o estimulara a compactar o arcabouço ficcional e a concentrá-lo sobre esses elementos mínimos" (BETTI, M. S. O Impulso e o salto: Boal em Nova York (1953-1955). Revista Sala Preta, volume 15, $\mathrm{n}^{\circ} 1,2015$, p.171).
} 
ao limite suas forças). $\mathrm{O}$ destino daqueles trabalhadores parece determinado por uma série de circunstâncias incontornáveis. A própria relação de amizade entre George e Lennie é marcada por momentos de generoso afeto e outros de explosão e raiva, com alguma crueldade por parte de George. Parece anunciar, ao fim, a impossibilidade de amizade real em um mundo regido pela exploração e miséria.

A questão do trabalho é central. Os personagens são apresentados pela sua relação produtiva e no que isso implica. Candy, um antigo trabalhador, perdeu um braço no trabalho, logo não servirá mais para nada. Do mesmo modo, a execução de um cachorro velho aparece como metáfora do descarte daqueles já inúteis para o trabalho. A questão produtiva é central e permeia as relações.

O capitalismo em jogo - marcado por relações arcaicas de exploração - é também avançado, o patrão presente não é o dono da fazenda, pertencente agora a uma grande companhia. A relação de trabalho é terceirizada.

As cenas finais são encadeadas em um crescente ritmo dos acontecimentos, com uma tragédia sucedendo-se a outra. Primeiro, Lennie e a Mulher de Curley - o filho do patrão - se encontram e mantém uma conversa de surdos, ambos falam e não se escutam. A esposa de Curley, a única personagem que não é nomeada, vive uma vida miserável ao lado do marido. Um cotidiano de constante humilhação e violências, em que sua única vontade era fugir, mas não tinha pra onde ir. Ela e Lennie conversam de um futuro em que suas vidas não seriam tão miseráveis, juntos procuram uma saída daquele buraco e entram numa espécie de êxtase. Nesse momento, Lennie encosta no cabelo da mulher, que se assusta. Ele, também assustado, tem um de seus acessos de descontrole e a mata, fugindo em seguida para o mato.

$\mathrm{Na}$ primeira cena da peça, George havia combinado com Lennie que se algo desse errado ele deveria se esconder naquele mato. Quando Curley descobre a mulher 
morta entra em estado de fúria e convoca a participação de todos os trabalhos na caçada para matar Lennie. George segue o bando e - lembrando-se do esconderijo combinado com Lennie - o encontra e decide ele mesmo matá-lo, antes que os outros o fizessem. Carregava consigo uma arma do patrão. Momentos antes de atirar no amigo, George retoma com Lennie a história que sempre repetiam, de que teriam o próprio rancho, cheio de lindos coelhos. A morte de Lennie acontece em um crescente de acúmulo emotivo. Lennie, completamente imerso na imaginação não percebe o momento em que George atira, pois estava de costas procurando enxergar um rancho imaginário, do outro lado do rio.

Steinbeck faz a reportagem da situação do capitalismo no sul dos Estados Unidos. Mas, como se trata de um drama social, as personagens da peça possuem uma estranha autoconsciência de suas condições miseráveis, da solidão em que vivem por conta da miséria, da exploração. Seres estragados pela determinação do trabalho são representados como indivíduos modernos autodeterminados. O flagrante de uma situação de miséria e exploração esbarra nos limites do modelo dramático. Não é possível apenas com diálogos e ações dramáticas dar conta de expor os processos sociais do estrago. Steinbeck apresenta a situação, mas não faz a análise, não expõe os processos de estrago e dominação.

O recorte social da peça é bastante claro. No entanto, a perspectiva de Boal ao escolhê-la não parece ter sido exatamente essa. O diretor recém-chegado dos EUA parecia querer encenar uma boa literatura realista, com diálogos contundentes, personagens bem delineados e com alta carga emotiva: excelente material para as técnicas stanislavskianas apreendidas nos Estados Unidos. 
Além disso, Steinbeck fez uma "nota de produção" em que recomenda que a maior parte da cenografia seja apenas sugerida, deixando para a imaginação do espectador completar o resto:

The point is that the dialogue and characterization are in themselves so important as to render unnecessary the usual sort of stage directions in which every entrance is specifically referred to and almost every move of every character carefully designated ${ }^{369}$

Steinbeck reforça a importância da relação entre as personagens e dos diálogos, que deveriam estar em primeiro plano. Essa perspectiva apontada pelo autor é uma indicação bastante conveniente ao espaço circular e diminuto do Teatro de Arena.

O texto é um modelo de carpintaria teatral, com três atos e duas cenas em cada ato, tudo muito bem engendrado nos diálogos e ações dramáticas. Esses pareciam ser os interesses de Boal: um bom texto que facilitasse a aplicação das técnicas de Stanislavski, para uma representação naturalista.

A escolha de Boal tinha a ver com questões técnicas e de modernização. Mas a técnica e o modelo de modernização a que Boal se referia eram bastante diversos daqueles praticados no modelo TBC. As técnicas que traz são ligadas a uma tradição contraditória dos Estados Unidos, cujo processo de modernização foi tardio e esteve muito ligado a trabalhadores e intelectuais de esquerda ${ }^{370}$, os mesmo que, paradoxalmente, anos depois participaram da formação e retomada da indústria de

\footnotetext{
${ }^{369}$ STEINBECK, J. Of Mice and Man. New York: Dramatists Play Service, Inc, 1964, p. 5. "O ponto é que o diálogo e a caracterização são em si tão importantes a ponto de tornar inútil o tipo usual de direções de palco, no qual cada entrada é especificamente referida e quase todos os movimentos de cada personagem são designados cuidadosamente" (tradução nossa).

${ }^{370}$ Sobre a questão ver: FLANAGAN, H. Arena: The History of the Federal Theatre. New York: Noble Offset Printers, 1940; COSTA, I. C. Panorama do Rio Vermelho. Ensaios sobre o Teatro Americano Moderno. São Paulo: Nankin Editorial, 2001.
} 
entretenimento (Hollywood e Broadway). A dramaturgia moderna norte americana do início do século XX é fortemente marcada pelas questões sociais e políticas e o texto Ratos e homens não foge à regra: sua estrutura dramática convive com um interesse pelos processos de desumanização do trabalho, o que resulta em personagens estragadas, nada parecidas com os modelos ideológicos do sujeito burguês autodeterminado. Na terminologia de Peter Szondi, o resultado é um drama em crise.

De todo modo, a novidade temática, por mais que não tenha sido explicitamente trabalhada pela encenação (ou pela recepção crítica) certamente entusiasmou os jovens do TPE, vindos da militância estudantil, que buscavam textos com esse tipo de conteúdo. Além disso, o novo tipo de trabalho, a partir de princípios stanislavskianos, colocado em prática por Boal decerto abriu um novo horizonte para os jovens atores comunistas do TPE, pois era um processo materialista de pesquisa e de investigação, que convidava a olhar para fora de si, a se interessar pelo outro e, no limite, pela própria realidade social do país. E era justamente isso que eles procuravam fazer.

A temática agrária era um assunto de grande evidência no Brasil daqueles anos, com a luta das Ligas Camponesas e a explosão de conflitos no campo. No entanto essa questão ou transposição para a realidade brasileira não é evidenciado no programa da peça e nem nas críticas da época. A opção da encenação, ao que consta, foi a de manter as localizações de espaço e tempo originais. Ainda assim, o programa de Ratos e homens esboça, mesmo que abstrata e genericamente, a questão social contida na peça, mas subordinando a materialidade da luta de classes a uma suposta "universalidade humanista" do tema, que talvez correspondesse mais ao tipo de abordagem da época.

Boal, por exemplo, escreve no "programa" que a obra de Steinbeck “caracteriza-se pelo desejo explícito ou implícito que sentem todas as personagens de se integrarem, de serem parte de um todo". Mas que "quando um indivíduo crava os 
dentes no que é de todos, e foge, e segue seu caminho solitário, e luta por essa causa que não é justa - esse indivíduo é maldito"371.

Alguns anos mais tarde, ao lembrarem-se da montagem os atores associam Ratos e Homens ao contexto brasileiro, aos boias-frias da atualidade. José Serber, que fez o papel de Lennie, anos depois, destaca um suposto valor universal da obra, a "solidão humana", de maneira mais ampla, mas logo em seguida traz a questão para o particular:

O tema, a solidão humana foi um problema que seria válido ate hoje. [...] A obra ainda seria atual porque na realidade aqueles homens sós, aqueles homens que viviam de suas fantasias, vendendo sua força de trabalho, de fazenda em fazenda, tendo trabalho periódico, ocasional, esses homens aqui no Brasil hoje chamam-se boias-frias. Então quase que poderia ter sido feito uma adaptação da obra de Steinbeck para uma problemática brasileira, dos boias-frias ${ }^{372}$.

De acordo com relato, também posterior, de Guarnieri, o aspecto social e a inversão de ponto de vista foram percebidos por ele - e pela turma do TPE. Tratava-se de uma peça cujo ponto de vista deslocava-se para o trabalhador, apresentando em linguagem realista sua condição de vida e o anseio de uma vida melhor. Além disso, as circunstâncias eram imediatamente adaptáveis para o contexto brasileiro.

Ratos e homens no contexto brasileiro marcou também um novo tipo de trabalho, em que a pesquisa atoral para a criação passou a ser determinante. O método Stanislavski a que Boal trava conhecimento em sua estadia nos Estados Unidos, foi

${ }^{371}$ BOAL, Augusto. Programa da peça Ratos e Homens no Teatro de Arena. Direção: Augusto Boal. Data: 26 de setembro de 1956.

372 Depoimento de José Serber In: LERNER, Julio. A Aventura do Teatro Paulista. [Filme-vídeo]. Produção e entrevistas de Júlio Lerner. São Paulo, série de televisão produzida pela TV Cultura, 1981. VHS. 
aquele desenvolvido por Lee Strasberg, a partir do contato com Richard Boleslavski e Maria Ouspenskaya ${ }^{373}$. O Actors's Studio vinha de uma tradição de teatro político de esquerda e no início não tinha as características mercadológicas associadas a sua estreita conexão com a indústria cinematográfica pela qual ficou conhecido ${ }^{374}$.

Quando Boal retorna ao Brasil pretende colocar em prática o resultado dessas ambivalentes observações e aprendizados no Actors's Studio e com John Gassner no início da década de 1950. É o início dos laboratórios de interpretação, que foram um contraponto à maneira de trabalhar do teatro profissional até aquele momento. Com os laboratórios, o cerne da criação passa a ser o trabalho em sala de ensaio e essa prática, coletiva, altera o sentido de encenação.

Uma vez que os atores tornam-se o centro da construção da cena, a questão da hierarquia interna entra necessariamente em crise. Os atores em suas práticas investigativas contribuem para a construção semântica da peça, para os sentidos de encenação e dramaturgia, portanto.

A relação imbricada entre os dois pensamentos, o do ator e o do dramaturgo, aparece no seguinte depoimento de Flávio Migliaccio:

\footnotetext{
373 Em 1925 os dois são convidados a ministrar aulas no American Laboratory Theater, onde Lee Strasberg estudava. Richard Boleslavski e Maria Ouspenskaya haviam decidido morar nos Estados Unidos após uma excursão que fizeram com o Teatro de Arte de Moscou em 1923. A linha que os professores russos seguiam era a vigente no Teatro de Arte de Moscou no início dos anos vinte, com foco na "memória emotiva" e na "interiorização" da personagem, mas ainda marcado pelo espírito materialista, de grupo e relacional que sempre animou o trabalho de Stanislavski na Rússia. A partir dos anos trinta Stanislavski desenvolve outra linha de pesquisa cujo foco principal passam a ser as "ações físicas". No entanto a condução de Lee Strasberg no Actors' Studio seguiu sendo àquela disseminada por Boleslavski e Ouspenskaya. (BETTI, M. S. Op. Cit., 2015, p.162).

${ }^{374} \mathrm{O}$ estúdio de formação de atores foi criado para dar continuidade à experiência do Group Theatre, pelo menos no plano do treinamento de atores no método Stanislavskiano adaptado por Strasberg. A bandeira do Group Theatre, fundado em 1931 por Harold Clurman, Cheryl Crawford e Lee Strasberg, era o teatro engajado. Apesar do fracasso do projeto teatral nos anos 1930 nos EUA e a mudança de sentido que o trabalho gestado ali teve, também é verdade que o ambiente onde tudo aquilo se desenvolveu prezava fundamentalmente por um teatro interessado na realidade. (COSTA, I. C. Panorama do Rio Vermelho. Ensaios sobre o Teatro Americano Moderno. São Paulo: Nankin Editorial, 2001, p. 38)
} 
E foram duas coisas ótimas que o Boal fez: o laboratório de interpretação e o Seminário de Dramaturgia. Os dois funcionavam quase ao mesmo tempo. Começou com interpretação e, depois, passou também pra dramaturgia. E era muito bom, porque ele deixava a gente improvisar no palco. A gente fazia um trabalho muito bom no palco, de interpretação, tentando quebrar com tudo que existia de ruim no teatro tradicional ${ }^{375}$.

Ao que tudo indica, os laboratórios de interpretação eram marcados por novidades como, por exemplo: a) improvisação livre sobre as cenas; b) tentativas de criar "nossas" maneiras de interpretar ao invés de importar inflexões "corretas"; c) interesse e observação da materialidade do dia a dia, interesse pelo outro, pela vida.

Essa pesquisa ajudou a fomentar a busca por um teatro brasileiro, por um corpo e atuação brasileiros, uma vez que o material pesquisado era o próprio gestual do ator, as emoções do ator e o corpo do ator. A busca por uma interpretação naturalista contribuiu para a superação de uma importação gestual. De acordo com Boal, anos mais tarde:

o laboratório de interpretação utilizando técnicas de Stanislavski nos ajudava a criar um estilo brasileiro de interpretação. [...] Nós partimos da expressão vital dos nossos atores, que eram brasileiros. [...] O elenco nosso era gente do povo, Milton Gonçalves, Flávio Migliaccio. Do povo até a classe média ${ }^{376}$.

\footnotetext{
${ }^{375}$ Entrevista de Flávio Migliaccio, Rio de Janeiro, 14.07.2015

${ }^{376}$ Depoimento de Augusto Boal In: LERNER, Julio. A Aventura do Teatro Paulista. [Filme-vídeo]. Produção e entrevistas de Júlio Lerner. São Paulo, série de televisão produzida pela TV Cultura, 1981. VHS.
} 
Esse tipo de representação "natural”, com a fala coloquial, mais realista, depois virou paradigma da interpretação brasileira, mas naquela época era novidade. Flávio Migliaccio contou que aquilo que o Boal tentava buscar e tirar dos atores, para ele era algo espontâneo, o jeito de ser dele, sem nenhum tipo de formação teatral.

\begin{abstract}
Ele deixava a gente improvisar no palco, tentando quebrar com tudo o que tinha de ruim no teatro tradicional. Um tipo de interpretação que não servia pra gente.
\end{abstract}

Os atores saíam às ruas imitando os gestos das pessoas, dos trabalhadores, criavam partituras. A ênfase dada à relação entre os atores, a famosa dialética das vontades cunhada por Boal, destoava do tipo de interpretação por marcações, vigente até aquele momento no Brasil.

Boal conta também que nesse período ele chegava ao teatro de Arena e os atores estavam todos espalhados pelo teatro, "gente até no banheiro", fazendo laboratório de interpretação, pesquisando gestos, improvisando cenas etc. E por mais que não tenham transposto a situação para a realidade brasileira é mais do que provável que internamente houvesse discussão nesse sentido, tendo em vista a explícita busca dos antigos integrantes do TPE por um teatro nacional popular e pelo engajamento político.

Ratos e Homens marcou um trabalho muito interessante no sentido de pesquisa de interpretação. Foi a primeira vez que fizemos um laboratório para valer na procura do que fosse o homem brasileiro, da rua, baseado nisso mesmo, da observação, procurando ter uma perspectiva popular, embora a peça fosse uma peça americana, mas uma peça de Steinbeck, uma peça que tratava do camponês 
americano e que permitia, de uma certa maneira, limitadamente, esse tipo de pesquisa e esse tipo de interpretação. ${ }^{377}$

Desde Ratos e homens a ênfase passa do espetáculo, da obra, para o processo, para a pesquisa. Uma pesquisa que procurava a relação com a matéria real da sociedade, que buscava entender as especificidades da condição brasileira (os atores, por exemplo, não precisavam ter o physique du rôle das personagens). De alguma forma, aquele ensaio mais espontâneo e ao mesmo tempo precário - marcado por debates de sentido político - do tempo de amador do TPE, ganhava critérios estabelecidos, uma sistematização. O Teatro de Arena inaugura então um tipo de experimentação mais livre da cena e do processo criativo.

Eles não usam black-tie: inauguração de um novo ciclo no teatro brasileiro

A prática instaurada a partir da encenação de Ratos e homens e as novas ferramentas de escrita dramatúrgica foram rapidamente assimiladas pelos componentes vindos do TPE. Ratos e homens deslocava o protagonismo para a classe operária. É possível inferir que do desenvolvimento desta relação surge um texto como Eles não usam black-tie, de Guarnieri.

Eu comecei a escrever para teatro após a chegada do Augusto Boal ao Arena. Eu estava muito entusiasmado com esta descoberta e este estudo da dramaturgia brasileira. Nós só discutíamos isso no Arena, vivíamos para este fim. Eu sentia que precisava fazer alguma coisa

\footnotetext{
377 GUARNIERI, Gianfrancesco em depoimento para o documentário A Aventura do Teatro Paulista Aventura do Teatro Paulista 5 e 6. Série de televisão produzida pela TV Cultura de São Paulo, em 1981. Produção e entrevistas de Júlio Lerner.
} 
para colaborar com aquele processo, então decidi escrever. Escrevia à noite, de madrugada, quando chegava em casa. Escrever me dava uma alegria imensa, uma sensação que eu não sentia havia muito tempo. Era um prazer infinito. [...] Terminei Black-Tie com 21 anos [...] foi minha primeira peça ${ }^{378}$

Eles não usam black-tie teve sua primeira versão escrita por Guarnieri em 1956, nas folgas dos ensaios de Ratos e homens. O drama apesar de tratar de uma greve numa fábrica continua a ser um drama social. É resultado de um anseio que vinha da época amadora do TPE, de sua experiência pessoal e com o PCB. De acordo com o depoimento de Flávio Migliaccio:

Naquela época, já tava muito claro que a gente tinha vontade de fazer um teatro que dialogasse com os operários, com estudantes, um teatro brasileiro. Isso veio desde o Teatro Paulista do Estudante, que já tinha isso, já tinha essa filosofia. Mas as peças que nós montamos não tinham. E no início do Arena também não tinha. Porque até a gente engrenar, ter uma peça brasileira pra gente fazer, demorou. $\mathrm{O}$ Guarnieri já tava escrevendo o Black-tie, já tinha ideia de fazer essa peça desde a época do Teatro Paulista do Estudante, mas a peça demorou um pouco pra chegar ${ }^{379}$.

A questão da temática nacional, que tratasse de assuntos pertinentes ao povo era já presente no programa do TPE, algo difundido entre eles desde o início. A escrita de Eles não usam black-tie figura como resultado direto dessa busca e de acordo com Iná

\footnotetext{
${ }^{378}$ GUARNIERI, G. Apud ROVERI, S. Gianfrancesco Guarnieri. Um grito solto no ar. São Paulo: Imprensa Oficial, 2004, p. 77.

${ }^{379}$ Entrevista de Flávio Migliaccio, Rio de Janeiro, 14.07.2015.
} 
cumpriu em certa medida esse anseio, pois trouxe ao teatro uma parcela geralmente apartada, estudantes e operários, que se identificavam com o tema ${ }^{380}$.

A peça, que no início foi batizada de Cruzeiro lá no alto, foi concebida para o elenco amador do $\mathrm{TPE}^{381}$. Mas paradoxalmente foi ela a salvadora do profissionalismo do Teatro de Arena, em 1958, trazendo sucesso de bilheteria e público. Mais que isso, o evento abriu uma nova etapa do teatro brasileiro.

A peça mostra a ascensão da luta operária dos anos 50 que foi realmente grande, bem como a participação e adesão do PCB nessas lutas, depois de um período de isolamento. No programa de Eles não usam black-tie, Guarnieri apresenta o contexto da seguinte forma:

Um conflito central move minhas personagens - a luta entre duas formas de pensar. De um lado a falta de perspectivas, o desajustamento, o medo da vida, de um Tião. De outro - a ideologia de Otávio, o sentimento profundamente proletário de Romana, Maria e dos verdadeiros moradores do barraco ${ }^{382}$.

Apesar do tema social, o conflito central da peça é entre pai e filho. Otávio é militante do partido, arraigado sindicalista que passara alguns anos presos devido a sua

\footnotetext{
${ }^{380}$ Guarnieri escreve assim, no programa da peça: "A ideia de escrever Eles não usam black-tie surgiu de uma necessidade. Necessidade de escrever sobre minha gente" - Programa da Peça Eles não usam blacktie, de Gianfrancesco Guarnieri. Direção: José Renato. Elenco: Mirim Mehler, Gianfrancesco Guarnieri, Flávio Migliaccio, Eugênio Kusnet, Lélia Abramo, Celeste Lima, Henrique Cesar, Francisco de Assis, Riva Nimitz, Milton Gonçalves. Estreia: 22 de fevereiro de 1958.

${ }^{381}$ Essa versão teve uma pré-estreia para convidados na casa de Beatriz Segall, que ficou à frente do TPE depois da fusão do núcleo principal com o Arena. O TPE seguiu existindo de forma autônoma, com direção de Beatriz Segall, quando montaram pelo menos mais duas peças: $O$ Almanjarra, de Artur de Azevedo e $O$ moço bom e obediente de B. Barr e G. Stevens, em 1957. Nessa segunda fase do TPE participam importantes nomes como Aracy Balabanian, Silnei Silqueira e Celeste Lima. Em sua biografia, Silnei Siqueira dedica um capítulo inteiro à importância de Beatriz Segall em sua formação como artista. Ele descreve como ela incutia nos atores com que trabalhava a necessidade de aprofundar os estudos acerca da obra, de conhecer o contexto. Incutia-lhes um sentido ético na profissão e uma busca pelas tradições do teatro brasileiro.

${ }^{382}$ Programa da Peça Eles não usam black-tie.
} 
atividade política. Seu filho, Tião, devido à prisão do pai, cresceu com os padrinhos endinheirados, como um agregado. O filho e o pai trabalham agora na mesma fábrica. A peça formalmente acompanha a trajetória de Tião diante de uma greve iminente. Ao mesmo tempo, Tião descobre que Maria, sua namorada, está grávida. Por essa e outras razões, Tião decide furar a greve. Iná Camargo Costa percebe ali, novamente, as hesitações da ruptura formal (que insiste no conflito dramático apesar do tema escancaradamente épico) e compara o conservadorismo da forma dramática à política do PCB no Brasil:

A verdade de Eles não usam black-tie reside justamente na contradição entre forma (conservadora) e conteúdo (progressista). A peça funciona como interessante radiografia do processo vivido pelo país: o avanço progressista das lutas dos trabalhadores era basicamente contido pelas formas conservadoras para as quais ele era canalizado - do PCB, em sua política de aliança de classes, passando pelo PTB, o principal instrumento de intervenção governamental nas organizações trabalhistas, aos sindicatos, federações e confederações devidamente controladas pelo Ministério do Trabalho ${ }^{383}$.

Ao mesmo tempo, Iná mostra em A hora do teatro épico no Brasil a força e importância que teve a peça de Guarnieri no teatro brasileiro, pela novidade temática na dramaturgia, cuja mudança de foco introduz, pela primeira vez, a luta do proletariado como protagonista ${ }^{384}$.

Não por acaso, a estreia da peça é um grande ponto de virada na trajetória da modernização do teatro brasileiro. A partir dali tem-se inicio um amplo movimento

\footnotetext{
${ }^{383}$ COSTA, I. C. A hora do teatro épico no Brasil. São Paulo: Paz e Terra, 1996, p. 39.
}

${ }^{384}$ Id. Ibid., p. 21. 
sistemático de politização, engajamento e radical experimentalismo das práticas artísticas - cada vez mais ligadas às populações excluídas até a interrupção violenta desse processo em 1964.

Eles não usam black-tie figurou como a concretização de um projeto que veio sendo maturado desde a fundação do TPE e que encontrou possibilidades produtivas na fusão com o Teatro de Arena. Sua estreia é mais um passo em direção ao programa esboçado desde o início do TPE e, que, por sua vez, conecta-se àquela tradição contrahegemônica de modernização popular. Com Black-tie, apesar das relutâncias formais, a ideia própria de nacional popular formulada pelos jovens do TPE a partir das posições e orientações de Ruggero Jacobbi ganha uma nova dimensão prática e produtiva e abre um horizonte enorme de atuação e experimentação.

É ali no encontro entre o Teatro de Arena, Boal e o TPE que nasce, enfim, uma cena nova, refuncionalizada; novos processos de trabalho; um pensamento próprio sobre dramaturgia popular e brasileira; experimentalismo radical no trabalho criativo e produtivo; uma organização em equipe; reflexão avançada sobre a história do teatro brasileiro; planos de circulação cada vez mais amplos e democráticos. Enfim, tudo aquilo que Jacobbi e o próprio TPE projetaram de formas variadas como um caminho popular de modernização para teatro.

O Teatro de Arena é o ambiente onde se conjuga todo este acúmulo histórico e que cria as condições para que o programa do TPE comece, enfim, a se realizar. Visto de outro modo, junto com Augusto Boal, o TPE é o empenho sistemático e engajado, a energia mesmo, que faz o Teatro de Arena tornar-se, de fato, um projeto que mudará os sentidos da modernização do teatro por aqui. 


\section{REFERÊNCIAS BIBLIOGRÁFICAS}

ABREU, Ieda de. Silnei Siqueira: a palavra em cena. Coleção Aplauso. São Paulo: Imprensa Oficial, 2009

ALMADA, Izaías. Teatro de Arena - uma estética da resistência. São Paulo: Boitempo Editorial, 2004.

ALTHUSSER, Louis. A Favor de Marx. Rio de Janeiro: Zahar Editores, 1967.

ANDERSON, Benedict. Comunidades imaginadas: reflexões sobre a origem e a difusão do nacionalismo. São Paulo: Companhia das Letras, 2013.

ANDERSON, Perry. Considerações sobre o marxismo ocidental - nas trilhas do materialismo histórico. São Paulo: Boitempo Editorial, 2004.

ANTONACI, Giovanna de Abreu. Os presos comunistas nos cárceres da Ilha Grande (1930-1945). Dissertação (mestrado em História) - Instituto de Ciências Humanas e Filosofia, Universidade Federal Fluminense, Niterói, 2014.

ARRABAL, José; LIMA, Mariângela Alves de. O nacional e o popular na cultura brasileira. São Paulo: Editora Brasiliense, 1983.

ARANTES, Otília. Política das artes. São Paulo: Edusp, 1995.

ARANTES, Paulo Eduardo. Sentimento da dialética - Na experiência intelectual brasileira. dialética e dualidade segundo Antonio Candido e Roberto Schwarz. São Paulo: Paz e Terra, 1992.

AUTRAN, Paula. Teoria e prática do Seminário de Dramaturgia do Teatro de Arena. São Paulo: dobra teatral, 2015.

BARCELLOS, Jalusa. C.P.C. da UNE: uma história de paixão e consciência. Rio de Janeiro: Nova Fronteira, 1994.

BARTHES, Roland. Escritos sobre o teatro. São Paulo: Editora Martins Fontes, 2007.

BARRENTO, João (org.). Realismo, materialismo, utopia (uma polêmica, 1935-1940). Lisboa, Portugal: Moraes Editores, 1978.

BASBAUM, Hersch. José Renato energia eterna. São Paulo: Imprensa Oficial, 2009.

BATTAGLIA, Maria José Almeida (Org.). Um pouquinho do teatro infantil. São Paulo: Centro Cultural São Paulo, 2008.

BERGSON, Henri. O Riso - ensaio sobre a significação do cômico. Rio de Janeiro: Jorge Zahar editora, 1983. 
BERNSTEIN, Ana. A crítica cúmplice - Decio de Almeida Prado e a formação do teatro brasileiro moderno. São Paulo: Instituto Moreira Salles, 2005.

BERTOLUCCE, Vanessa Beatriz. A arte dos regimes totalitários do século XX: Rússia e Alemanha. São Paulo: Annablume; FAPESP, 2008.

BETTI, Maria Silvia. Oduvaldo Vianna Filho. São Paulo: Edusp, 1997.

BOAL, Augusto. Hamlet e o filho do padeiro - memórias imaginadas. Rio de Janeiro: Record, 2000.

. Teatro do Oprimido e outras poéticas. Rio de Janeiro: Civilização brasileira, 2010 .

BOTELHO, André; BASTOS, Elide Rugai; VILLAS BÔAS, Glaucia (Org.). $O$ moderno em questão - A década de 1950 no Brasil. Rio de Janeiro: Topbooks, 2008.

BRANDÃO, Tânia. Uma empresa e seus segredos: companhia Maria Della Costa. São Paulo: Perspectiva, 2005.

BRECHT, Bertolt. A compra do latão [1939-1955]. Lisboa: Vega, 1999. Bertolt Brecht Poemas 1913-1956 (Seleção e tradução de Paulo César de Souza). São Paulo: Editora 34, 2000.

BRETON, André; TROTSKI, Leon; GALVÃO, Patrícia. [et. Al]. Por uma arte revolucionária independente. (tradução de Carmem Sylvia Guedes, Rosa Maria Boaventura). São Paulo: Paz e Terra: CEMAP, 1985.

BROWN, Ivor John Carnegie. J. B. Priestley. London: Published for the British Council and the National Book League by Longmans, Green, 1964.

BÜRGER, Peter. Teoria da Vanguarda. Cosac Naify: São Paulo, 2008.

CALDWELL Erskine. Tobacco Road. Boston: Little, Brown and Company, 1934.

CAMARGO, Angelica Ricci. O teatro em discussão: os primeiros Congressos Brasileiros de Teatro (1951 e 1953). Anais eletrônico do XXII Encontro Estadual de História da ANPUH-SP Santos SP, 2014.

CAMPOS, Claudia de Arruda. Zumbi Tiradentes. São Paulo: Editora Perspectiva, 1988.

CANDIDO, Antonio. Formação da literatura brasileira. Momentos decisivos. $10^{\mathrm{a}}$ ed. Rio de Janeiro: Ouro Sobre Azul, 2006.

CANFIELD, Curtis. Plays of Changing Ireland. New York: The Macmillan Company, 1936.

CARBONE, Roberta. O trabalho crítico de João das Neves no jornal Novos Rumos em 1960: perspectivas sobre a construção de um fazer teatral épico-dialético no 
Brasil. Dissertação (mestrado em Artes Cênicas) - Escola de Comunicações e Artes, Universidade de São Paulo. São Paulo, 2014.

CARVALHO, Martinho de; DUMAR, Norma (Org.). Paschoal Carlos Magno - Crítica teatral e outras histórias. Rio de Janeiro: FUNARTE, 2006.

CARVALHO, Sérgio de. O drama impossível: teatro modernista de António de Alcântara Machado, Oswald de Andrade e Mário de Andrade. Tese (doutorado em Literatura Brasileira), Faculdade de Filosofia, Letras e Ciências Humanas, Universidade de São Paulo, São Paulo, 2002.

Atitude modernista no teatro brasileiro. In: ARAÚJO, Antonio; AZEVEDO, José Fernando Peixoto de; TENDLAU, Maria (Org.). Próximo ato: Teatro de grupo. São Paulo: Itaú Cultural, 2011.

CEPEDA, Norival Albergaria; MARTIN, Maria A. Fernandes. MASP 1970: o psicodrama. São Paulo: Ágora, 2010.

CHAUI, Marilena. Seminários - o nacional e o popular na cultura brasileira. São Paulo: Editora Brasiliense, 1983.

COSTA, Iná Camargo. A hora do teatro épico no Brasil. São Paulo: Paz e Terra, 1996. . Nem Uma Lágrima - teatro épico em perspectiva dialética. São Paulo: Expressão Popular, 2012. . Panorama do Rio Vermelho. Ensaios sobre o Teatro Americano Moderno. São

Paulo: Nankin Editorial, 2001. Sinta o drama. Petrópolis: Vozes, 1998.

DENIZOT, Marion. Théâtre populaire et représentations du peuple. Rennes: Presses Universitaires de Rennes, 2010.

DIAS, Antonio Gonçalves. Teatro completo. Rio de Janeiro: Serviço Nacional de Teatro, 1979.

DORT, Bernard. O teatro e sua realidade. $2^{\text {a }}$ ed. São Paulo: Perspectiva, 2010.

EAGLETON, Terry. A ideia de cultura. São Paulo: Editora Unesp, 2005.

ELIOT, T. S. Tradição e talento individual. In: Ensaios. São Paulo: Art Editora, 1989.

FARIA, João Roberto (Org.). História do teatro brasileiro 2 - do modernismo às tendências contemporâneas. São Paulo: Editora Perspectiva e SESC/SP, 2013.

FAYA, Orleyd Rogéria Neves. Teatro Paulista de Amadores: 1964-1985. A Trajetória do Movimento Federativo nos 21 anos da Ditadura Militar no Brasil: Preâmbulo Histórico Cultural. São Paulo: USP, 2005. 
FERNANDES, Karina Pinheiro. O povo é arte: as ilustrações em periódicos do PCB e o realismo socialista no Brasil. Anais do XXVI Simpósio Nacional de História ANPUH. São Paulo, julho 2011.

FLANAGAN, Hallie. Arena: The History of the Federal Theatre. New York: Noble Offset Printers, 1940.

GARCIA, Clóvis. Os caminhos do teatro paulista: um panorama registrado em críticas: O Cruzeiro (1951-1958), A Nação (1963-1964). São Paulo: Prêmio, 2006.

GERTEL, Vera. Um gosto amargo de Bala. Rio De Janeiro: Civilização Brasileira, 2013.

GRAMSCI, Antonio. Cadernos do cárcere. Rio de Janeiro: Civilização Brasileira, 2000. 6 Volumes.

. Literatura e vida nacional. Rio de Janeiro: Editora Civilização brasileira, 1968. . Os intelectuais e a organização da cultura. Rio de Janeiro: Editora Civilização brasileira, 1968.

GUZIK, Alberto. TBC: crônica de um sonho. São Paulo: Perspectiva, 1986.

HIRST, David L. Giorgio Strehler. Birmingham: Cambridge University Press, 1993.

JACOBBI, Ruggero. A expressão dramática. São Paulo: Ministério da Educação e Cultura/Instituto Nacional do Livro, 1956.

- Crítica da razão teatral: o teatro no Brasil visto por Ruggero Jacobbi. (Organização de Alessandra Vannucci). São Paulo: Perspectiva, 2005.

. Goethe, Schiller, Gonçalves Dias. Porto Alegre: Edições da Faculdade de Filosofia, 1958.

. Teatro no Brasil. São Paulo: Editora Perspectiva, 2012.

KHOURY, Simon. Atrás da máscara. Rio de Janeiro: Civilização Brasileira, 1984. Volume 1.

KONDER, Leandro. A democracia e os comunistas no Brasil. Rio de Janeiro: Editora Graal, 1980.

LEBERT, Nilu. Beatriz Segall - Além das aparências. São Paulo: Imprensa Oficial, 2007.

LOCATELLI, Stefano. Teatro Pubblico Servizio: Studi sui primordi del Piccolo Teatro e sul sistema teatrale italiano. Milano: Centro dell Arti, 2015. 
LOWY, Michael (Org.). O marxismo na América Latina - uma antologia de 1909 aos dias atuais. $2^{\mathrm{a}}$ edição ampliada. São Paulo: Editora Fundação Perseu Abramo, 2006.

LUKÁCS, Gyorg. Introdução a uma estética marxista. Rio de Janeiro: Civilização Brasileira, 1968.

MAGALDI, Sábato. Panorama do teatro brasileiro. São Paulo: Difusão Europeia do Livro, 1962.

MAGALHÃES, Mário. Marighella - o guerrilheiro que incendiou o mundo. São Paulo: Companhia das Letras, 2012.

MÂNFIO, Gisela Borges Garnier. Tradição e Inovação: Elementos da poética do teatro em Lennox Robinson. Dissertação (mestrado em Letras), Faculdade de Filosofia, Letras e Ciências Humanas, Universidade de São Paulo, São Paulo, 1996.

MICHALSKI, Yan; ROSYANE, Trotta. Teatro e Estado - As Companhias Oficiais de Teatro no Brasil: história e polêmica. São Paulo - Rio de Janeiro: Editora Hucitec, Instituto Brasileiro de Arte e Cultura, 1992.

MIRANDA, Orlando (Org.). Coleção Depoimentos II - Personalidades Teatrais. Rio de janeiro: Serviço Nacional de Teatro, 1977.

. Coleção Depoimentos $V$ - Personalidades Teatrais. Rio de janeiro: Serviço Nacional de Teatro, 1981.

MORAES, Denis de (Org.). Combates e utopias. Rio de Janeiro/São Paulo: Editora Record, 2011.

MORAES, Denis de. Vianinha cúmplice da paixão. Rio de Janeiro: Ed. Record, 2000. O imaginário vigiado - a imprensa comunista e o realismo socialista no Brasil (1947-53). Rio de Janeiro: José Olympio, 1994.

MORAES, João Quartim. História do Marxismo no Brasil - Teorias. Interpretações. São Paulo: Editora Unicamp, 2007. Volume 3.

OLIVEIRA, Francisco de. Crítica à razão dualista. São Paulo: Boitempo, 2003.

OLIVEIRA, Lucia Lippi, Cultura e identidade nacional no Brasil do século XX. In: GOMES, Angela de Castro; PANDOLFI, Dulce Chaves; ALBERTI, Verena (Org.), A República no Brasil. Rio de Janeiro: Editora Nova Fronteira, 2002.

ORTIZ, Renato. Cultura brasileira e identidade nacional. São Paulo: Brasiliense, 2006; PASTA Jr., José Antonio. Formação supressiva - constantes estruturais do romance brasileiro. Tese de Livre-Docência na Área de Literatura Brasileira, apresentada 
à Faculdade de Filosofia, Letras e Ciências Humanas da Universidade de São Paulo. São Paulo, 2011.

PEIXOTO, Fernando. Um teatro fora do eixo. $2^{\mathrm{a}}$ ed. São Paulo: Editora Hucitec, 1997. . Teatro em questão. São Paulo: Editora Hucitec, 1989.

. Teatro em Movimento. São Paulo: Hucitec, 1989.

PEIXOTO, Fernando (Org.). Vianinha (Teatro, televisão, política). São Paulo: Brasiliense, 1983.

PÉCORA, José Renato. Coleção Ciclo de Palestras sobre o Teatro Brasileiro, 4. Rio de Janeiro: INACEN, 1987.

PISCATOR, Erwin. Teatro Político. Madrid: Editorial Ayuso, 1976.

. Teatro Político. Rio de Janeiro: Civilização Brasileira, 1968.

PONTES, Joel. O teatro moderno em Pernambuco. São Paulo: Buriti, 1966.

PRADO, Decio de Almeida. Apresentação do teatro brasileiro moderno. São Paulo: Perspectiva, 2001. . O teatro brasileiro moderno. $3^{\mathrm{a}}$ ed. São Paulo: Perspectiva, 2009. . O drama romântico brasileiro. São Paulo: Perspectiva, 1996. . História concisa do teatro brasileiro. São Paulo: Edusp, 1999.

PRADO JUNIOR, Caio. A Revolução Brasileira. $7^{\text {a }}$ ed. São Paulo: Brasiliense, 2004.

PRIESTLEY, John Boynton. Está lá fora um inspetor: peça em 3 atos. Petrópolis Editora Vozes, 1966.

RAULINO, Berenice. Ruggero Jacobbi: presença italiana no teatro brasileiro. São Paulo: Perspectiva, 2002.

REIS, Claudio. O Nacional Popular em Antonio Gramsci. 2009. Tese (Doutorado em Ciências Sociais) - Instituto de Filosofia e Ciências Humanas, Universidade Estadual de Campinas, Campinhas, 2009.

RIDENTI, Marcelo. Brasilidade revolucionária. São Paulo: Editora Unesp, 2010. . Em busca do povo brasileiro: artistas da revolução, do CPC à era da TV. Rio de Janeiro/São Paulo: Editora Record, 2000.

ROLLAND, Romain. Le Théâtre du peuple (1903). Bruxelles: Éditions Complexe, 2003.

ROSENFELD, Anatol. O mito e o herói no moderno teatro brasileiro. $2^{\text {a }}$ ed. São Paulo: Perspectiva, 1996.

ROUBINE, Jean-Jacques. A linguagem da encenação teatral. Rio de Janeiro: Jorge Zahar Editor, 1998. 
ROSA, Marcus Wesley Guimarães; FÍGARO, Roseli (orientação). Teatro Amador Cultura de Estado: políticas públicas e censura em relação ao teatro amador. Relatório final CNPQ/PIBIC - Escola de Comunicações e Artes, Universidade de São Paulo, 2008.

ROVERI, Sérgio. Gianfrancesco Guarnieri: um grito solto no ar. São Paulo: Imprensa Oficial, 2004.

ROXO, Marco; SACRAMENTO, Igor. Intelectuais partidos: os comunistas e as mídias no Brasil. Rio de Janeiro: Editora E-Paper, 2012.

SANTOS, Jacqueline Pithan. Miroel Silveira - um homem do seu tempo. Dissertação (mestrado em Estética e História da Comunicação), Escola de Comunicação e Artes, Universidade de São Paulo, São Paulo, 2010.

SARRAZAC, Jean-Pierre. Critique du theater - De l'utopie au désenchantement. Belval: Circé, 2009.

SCHWACZ, Lilia Moritz. Estado sem nação: a criação de uma memória oficial no Brasil do Segundo Reinado. In: NOVAES, Adauto (Org.). A Crise do EstadoNação. Rio de Janeiro: Civilização Brasileira, 2003.

SCHWARZC, Lilia Moritz; STARLING, Heloisa. Brasil: uma biografia. São Paulo: Companhia das Letras, 2015.

SCHWARZ, Roberto. Ao vencedor as batatas. São Paulo: Duas Cidades/Editora 34, 2008 . O Pai de família e outros estudos. São Paulo: Companhia das Letras, 2008. . Cultura e política, 1964-1969. In: O Pai de Família e outros estudos. São Paulo: Companhia das Letras, 2008.

. Um mestre na periferia do capitalismo - Machado de Assis. São Paulo: Duas Cidades/Editora 34, 2000.

. Nacional por subtração. In: Que horas são? São Paulo: Cia. das Letras, 1987.

. Sequências brasileiras - ensaios. São Paulo: Companhia das Letras, 1999.

SECCO, Lincoln. Gramsci e a revolução. São Paulo: Alameda Editorial, 2006.

SILVEIRA, Miroel. A contribuição italiana ao teatro brasileiro. São Paulo: Quíron, 1976. . A outra Crítica. São Paulo: Ed. Símbolo, 1976.

SOUZA, Gilda de Mello e. Exercícios de Leitura. São Paulo: Editora 34, 2009.

STEEN, Edla Van. Eva Wilma arte e vida. São Paulo: Imprensa Oficial, 2006. 
STEINBECK, John. Of Mice and Man. New York: Dramatists Play Service, Inc, 1964. STREHLER, Giorgio. Per un teatro umano. Pensieri scritti, parlati e attuali, a cura di S. Kessler. Milano: Feltrinelli, 1974.

SZONDI, Peter. Teoria do drama moderno. São Paulo: Cosac \& Naify, 2001.

TOLEDO, Paulo V. Bio. Impasses de um teatro periférico: as reflexões de Oduvaldo Vianna Filho sobre o teatro no Brasil entre 1958 e 1974. 2013. Dissertação (Mestrado em Teoria e Prática do Teatro) - Escola de Comunicações e Artes, Universidade de São Paulo, São Paulo, 2013.

TROTSKI, Leon. Literatura e revolução. Rio de Janeiro: Editora Zahar, 1969.

VANNUCCI, Alessandra. Missão Italiana. São Paulo: Perspectiva, 2014.

VARGAS, Maria Theresa. O Teatro Operário na cidade de São Paulo. São Paulo: Departamento de Informação e Documentação Artísticas, Secretaria Municipal da Cultura, 1980.

VIANNA, Deocélia. Companheiros de viagem. São Paulo: Editora Brasiliense, 1984

WILLIAMS, Raymond. Política do modernismo. São Paulo: Editora Unesp, 2011.

\section{Artigos em revistas e periódicos}

Sem assinatura, críticas - A rua da igreja, o Estado de São Paulo, domingo, 05 de junho de 1955, palcos e circos amadores.

BETTI, Maria Silvia. O Impulso e o salto: Boal em Nova York (1953-1955). In: Revista Sala Preta, São Paulo, volume 15, nº1, 2015 p.171.

CANDIDO, Antonio. Os feitos da burguesia. Revista Discurso. São Paulo, no 11, pp. 125-130, 1979.

FIGARO, Roseli. Quem são e qual a importância dos grupos amadores de teatro? APARTE. São Paulo. No XXI. 2012.

GARCIA, Clóvis. Teatro, O Cruzeiro, 16 de julho de 1955. Teatro em São Paulo, O Cruzeiro.

GRASSI, Paolo. Teatro, pubblico servizio. Avanti!, 25 aprile 1946.

GONÇALVES, Delmiro. O impetuoso capitão Tic, 10 de novembro de 1955, sem referência ao jornal.

IANNI, Octávio. A mentalidade do homem simples. Revista Civilização brasileira. Rio de Janeiro. Número 18, Ano III, mar.-abr. 1968. 
JACOBBI, R. Atualidade de Goldoni. O Estado de S. Paulo. Suplemento Literário. Ano 2, n ${ }^{\mathrm{o}} 1,21$ dez. 1957.

LIMA, Mariângela Alves de. História das Ideias. Revista Dionysos, Rio de Janeiro: MEC-SNT, n 24 outubro de 1978, p. 33 e 34.

MARQUES, Azevedo, sem título, A Imprensa, 1955.

MORAES, Denis. Antonio Gramsci e o jornalismo. Carta Maior. 24-08-2014.

NAPOLITANO, Marcos. A arte engajada e seus públicos (1955-1968). Estudos Históricos, nº 28, p.103-24, Rio de Janeiro: Fundação Getúlio Vargas, 2001.

PACHECO, Mattos. A rua da igreja, Diário da Noite Ronda. . Está lá fora um inspetor. Diário da Noite Ronda. O impetuoso capitão Tic, Diário da Noite 09/11/1955.

PRADO, Décio de Almeida. Mirandolina. O Estado de S. Paulo, Coluna Palcos e Circos, 17.7.1955.

RIBEIRO, Jayme Fernandes. Os “inimigos da paz”: estado, imprensa e a repressão ao movimento dos “partidários da paz” no Brasil (1950-1956). Saeculum - Revista de História. João Pessoa, jul./ dez. 2007.

SARRAZAC, Jean-Pierre. A invenção da teatralidade (tradução de Silvia Fernandes). Sala Preta, Brasil, v. 13, n. 1, p. 56-70, jun. 2013.

ZHDANOV, Andrêi. As Tarefas da Literatura na Sociedade Soviética. Problemas. Revista Mensal de Cultura Política nº 20, ago.-set. 1949.

\section{Entrevistas}

Entrevista com Alessandra Vannucci feita por Sara Mello Neiva dia 23.03.2015.

Entrevista com Beatriz Segall feita por Sara Mello Neiva e Paula Autran dia 24.04.2015.

Entrevista com Flavio Migliaccio feita por Sara Mello Neiva e Paula Autran dia 14.07.2015.

Entrevista inédita com Aracy Amaral feita por Sara Mello Neiva dia 28.05.2015.

Entrevista com Gianfrancesco Guarnieri concedida a Alessandra Vannucci, São Paulo, 1997.

Entrevista com Maria Lúcia Vianna feita por Sara Mello Neiva e por Paula Autran dia 14.07.2015. 
Entrevista com Milton Gonçalves feita por Sara Mello Neiva e por Paula Autran dia 16.07.2015.

Entrevista com Regina Helena de Paiva feita por Sara Mello Neiva dia 13.04.2015.

\section{Programas de peças}

Programa da peça Ratos e Homens no Teatro de Arena. Direção: Augusto Boal. Data de estreia: 26 de setembro de 1956.

Programa da peça Essas Mulheres. Direção: José Renato. Data de estreia: de 21 de junho de 1956. Síntese do acordo firmado entre o Teatro de Arena e o Teatro Paulista de Estudante.

Programa do Festival Artur Azevedo - Comemorando o centenário de nascimento de Artur Azevedo. Organizado por Teatro Paulista de Estudante e Federação Paulista de Teatro.

Programa de A Rua da Igreja, direção Sofia Rosenhaus, supervisão de Ruggero Jacobbi. Estreia: 30.05.1955. Teatro de Arena.

Programa de Está Lá Fora Um Inspetor, direção de Raymund Duprat. Estreia: 15.09.1955. II Festival Paulista de Teatro Amador, Teatro São Pedro.

Programa de O Impetuoso Capitão Tic, direção Ítalo Rossi, estreia: Estreia em 07/11/1955 - 21:00 horas - Teatro de Arena - Rua Teodoro Baima, 94.

Programa Oficial do II Festival Paulista de Teatro Amador. Teatro São Paulo, setembro 1955.

Programa de Escola de Maridos, direção de José Renato.

\section{Revistas e periódicos}

ARTE EM REVISTA 3 - Questão Popular, Ano 3, Número 3, São Paulo: Editora Kairós, março de 1980.

COMOEDIA No 6 - Revista Mensal de Teatro, Música, Cinema e Rádio. Rio de Janeiro, 1947.

REVISTA DO TEATRO AMADOR. São Paulo: Federação Paulista de Teatro Amador, ano $1, n^{\circ} 3$, out. de 1955.

REVISTA DO TEATRO AMADOR. São Paulo: Federação Paulista de Teatro Amador, Ano 1, no 5, dez. 1955. 
REVISTA DO TEATRO AMADOR. São Paulo: Federação Paulista de Teatro Amador, Ano 1, nº 6, jan. 1956.

REVISTA DO TEATRO AMADOR. São Paulo: Federação Paulista de Teatro Amador, ano $1, \mathrm{n}^{\mathrm{o}}$ 7, fev.-mar. 1956.

REVISTA DIONYSOS. Ano XII nº 15, Rio de Janeiro: MEC-SNT, dez. 1967.

REVISTA DIONYSOS. Rio de Janeiro: MEC-SNT, nº 23 set. 1978.

REVISTA DIONYSOS. Rio de Janeiro: MEC-SNT, nº 24 out. 1978.

REVISTA DIONYSOS. Rio de Janeiro: MEC-SNT, nº 25, set. 1980.

REVISTA DIONYSOS. Rio de Janeiro: MINC - FUNDACEN, n 29, 1989.

REVISTA SEQUÊNCIA CINEMA E TEATRO. ano 1, nº 1, São Paulo, janeiro de 1956.

REVISTA TEATRO BRASILEIRO. nº 6, São Paulo, 1956.

\section{Filmes e documentários}

LERNER, Julio. A Aventura do Teatro Paulista. [Filme-vídeo]. Produção e entrevistas de Júlio Lerner. São Paulo, série de televisão produzida pela TV Cultura, 1981. VHS

GRINSPUM. Marighella.[Filme] Direção: Isa Grinspum Ferraz. São Paulo, Downtown filmes, 2012. DVD.

Memória Roda Viva (http://www.rodaviva.fapesp.br)

\section{Documentos}

BARROSO, Maurício; CIVELLI, Carla (tradução e adaptação). A ronda dos malandros. Material datilografado. Cópia de prontuário do Departamento Estadual de Imprensa e Propaganda (DEIP) de São Paulo. Arquivo Miroel Silveira - Escola de Comunicações e Artes, mar. 1950.

LABICHE, Eugene. O Impetuoso Capitão Tic - comédia em três atos. Material datilografado (sem registro de tradução), Biblioteca da Escola de Comunicações e Artes, [19--].

Cópia da ata da Fundação do Teatro Paulista de Estudante. 05.04.1955. $4^{\mathrm{o}}$ registro de títulos e documentos, São Paulo, Dr. Sebastião Medeiros. 
Cópia do Registro de Pessoas Jurídicas - os estatutos da sociedade civil denominada

Teatro Paulista do Estudante - no $4^{\circ}$ Registro de Títulos - cartório Sebastião Medeiros.

Convite para o cocktail de lançamento da Noite de Arlequim

Relatório de Guarnieri à Fundação Vitae, 2005. Documento cedido por Vanya Sant'Anna.

Recorte de jornal sobre a estreia do Festival Artur Azevedo, realizado pelo TPE em parceria com a Federação Paulista do Teatro Amador. sem assinatura e sem data. 
ANEXOS

1. Estatuto de fundação da Sociedade Paulista de Teatro

2. Tese do TPE apresentada no II Congresso de Teatro Amador

3. Acordo de fusão entre o TPE e o Teatro de Arena 
encenar as obras imortals literatura dramática, além de espetáculos especlals de conteúdo histórico ou patribtico. b) - Comanhia de Teatro Cômlco, para levar aos bairros populares peças divertidas e fácels, que encaminhem através do humorlsmo e da sátira o público ao teatro, como diver são sadia e necessária. c) Companhia de Teatro Infant1l pạ ra criar nas novas gerações o amōr pelo teatro e para contribuir através do teatro, à educação moral e intelectual da juventude. d) Teatro Experimental de S. Paulo para reve lar e lançar os novos autores brasileiros, sempre a procura de uma oportunidade no teatro comercial, mórmente quando se dedicam as formas de literatura teatral mais moder nas e ousadas. Capitulo II - Dos Sodios- Art. 40- A S.P.T. terá sócios de três categorias: a) sócios fundadorès: tồdos os que assinarem as três primeiras atas da sociedade,b) - Sóclos honorários: serão eleitos por unanimidade da Diretoria, c) Sócios contribuintes: pessôas interessadas mo teatro por qualquer motivo intelectual, artistico ou técni co que quelram, através de sua contribuição, ajudar ao des envolvimento da S.: P. T. e garantir para si mesmos a poss 1 bilidade de asolstirem a tôdas as suas realizações. Capitul 10 III - Dos Deveres e Direitos dos Sócios- Art. 50 -Us S으 cios terão direito a uma entrada gratuita nas estreias das realizações da S. P. T. Art. 60 - Us Sócios contribuintes serão obrigados a uma anuidade que será determinada pela Diretorla. Art. 70 - Convocar a Assembléla Geral vixtraordi nária. Art. 80 - Candidatar-se a qualquer cargo de Adminis tração da Socledade- Capltulo IV - Das Assembléias GieraisArt. 92 - O Orgão Soberano da S. P. T. é a Assembléla Geral Ordinária ou Extraoránária- \$10 A Assembléla Geral Or dinf́ria reunir-se-a uma vez por ano, na segunda quinzena de 




de malo, por convocação do Presidente da Sociedade e edi tal públicado no Diário oficial do sistado. A Assembléla Ge ral Ordinária realizar-se-á em primeira covocação com a metade mais um dos sóclos quites com os cofres da sociedade ou, em segunda convocação, uma hora depois no mesmo local, com qualquer número de sócios. § 22 A Assembléla Geral Extraordinárla realizar-se-à en qualquér tempo por convocação: a) do Presidente; b) de un terço dos membros da Diretoria; c) de un terço dos sócios quites com os cofres da sociedade; d) do Conselho fiscal- Capitulo V - Da Diretoria- Art. 100 - A Assembléia Geral Ordinária compete aprovar o rélatório anual e a prestação de contas- Art. 110- A Diretoria da S. P. T. seró eleita por dois anos pela Assembiéla Geral Ordinária e composta dos seguintes elementos: um Presi dente, dois V1ce-Presidentes, dois secretários, dois lesou reiros e um Conselho Fiscal de cinco membros. a) Compete ad Presidente presidir à Assembléla Geral, às reuniões da Diretoria, bem como convocar Assemblélas Extrạorịnárias; representar a Sociedade junto aos Poderes Púbilcos, em Juizo e fơra dêle; levantar depósitos bancários juntamente com 0 Tesoure1ro; assinar o relatório das atividades anuais. b)Compete ao Vice-Presidente substituir o rresidente em tôdas as suas funções em caso de impedimento dëste último. c) Ca be ao Secretário redigir as atas das Assemblélas e atender ao expediente da Secretaria. d) Cabe ao lesoureiro levantar depósitos bancários juntamente com o presidente e assinar a prestação de contas anual. e) Cabe ao Conselho fiscal verificar o relatório amal e a prestação de contas. Art. 120 Para a realização do seu programa a Diretoria contratará os trabalhos de equipes produtoras de espetáculos assim const1 tuldas: a) Direção artística composta de um viretor e um AS 
Assistente. b) Direção de Producão composta de um viretor e um Secretário c) Elenco composto de atôres e figurantes d) Equipe Técnica composta de un chefe-maquinista,um chefeeletricista, um contra-regra, cada um com os auxiliares que os vários espetáculos tornarem necessários. e) Eventuats, contribulęões esporádicas de outros técnicos para casos especláls como $s \in$ jam: coredgrafos, regentes de orquestras, mú sicos, professores de esgrima e de dança, etc. Art. 130- A Diretoria escolhera o Diretor Artistico e o virètor de Producão de cada espetáculo e estès contratarão livremente os dema1s elementos, com a colaboração e aprovação do l'esoure1 ro pelo que se refira a parte econômica. Art. 142- Inicialmente, os contratos feitos entre a S. P. T. e os integran tes das equipes artísticas e técnicas terão a duração limitada a um espetáculo. Depois da estreia da primeira equipe será debatido pela Diretoria o problema da formação eventual de equipes permanentes. Capituro V I - Da Séde- Art. 158 A séde da S. P. T. seŕa na cidade de S. Paulo. Capitulo VII da Dissolução- Art. 162 A dissolução da sociedade será realizada em Assembléia Geral Extraordinária, convocada espect almente para êsse fim. Art. 170 - Em caso de dissolução da Sociedade, O patrimônio reverterá em beneficio de sociedade Congênere, a critério da Assembléia Geral. Capitulo VIII Disposisões gerais- Art. 180-Mọ sócios não respondem, nem subsidiariamente, pelos compromissos assumidos pela socieda de. Art. 199 - A alteração destes Éstátutos so pölerá ser feita em Assembiéla Geral. Art. 202 Os Casos omissos nêstế Estatutos serão résolvidós pela Diretoria- sócledade Paulis ta de Teatro- Diretoria- Presidente: :Prof. Canuto Mendes de Almeida, brasile1ro, 42 anos resrav. Angelica 1.653, profissão, advogado-Vice-Presidente: Huggero Jacobbi, Italla- 




1500 $1 \div 00$ (nivingas

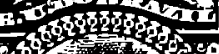
Fin sustas if 7 ciar a 1

1100 ivopintros ipendy

15001500

150061500

\%


w. oustas

- 13 incia





(2) in 0 ins

$\sqrt{15006}$ 4 ग

int

inif

47

of 6 la

s

15 .

U

is $100 \sqrt{100}$


(6) $515 \%$



$\rightarrow \rightarrow$

Shoja




OQ

$\sin 6150$





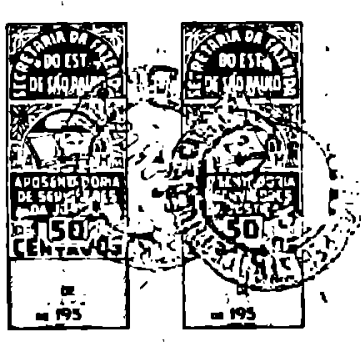

1tallano, jornal1sta, 32 anos, res: Iua Martins Fontes, 213 ap. 71- 10) Tesoureiro: Dr. Vicente latalano, brasileiro,mg dico, 42 anos, res: C1ty Hotel- 20 'lesoureiro: Vera Nunes, brasileira, atriz, 27 anos, res: Prça da Bandeira, edifíciф Brasilar. 10 Secretário: ar. Julio Gouveia, brasileiro, mét. dico, 36 anos, res: ma Itacolomi 397- 20 secretário: Mag dalena NIcol, brasileira, atriz, 31 anos, res; Av. Paulista 2.584, ap. 91. (Sôbre dois sëlos estadoałs somando Cir. $\$ 2,00)$ S. Paulo, 3 de Julho : de 1951 (assinado): C.Mendes de Almeida- 3-de 7 de 1951 (duas vezes- No verso de todas as folhas $\in$ stava o seguinte carimbo)- Secretaria da segurança Públıca- Departamento de Investigações- Divisão de DI versões Pĺblicas- Aprovado, na parte que compete a esta UIvisão a vista do $\$ 10$ do art. 10 do dec. ne 16724, de 16/1/ 47 e do que determina o $\$$ único do art. 127 do dec. fed. no 4857, de 9/11/39, modificado pelo dec. fed. no 5318 de $29 /$ 1/40, sem prejuizo de apreclação, aprovação ou alteração, por parte de outras autoridades. s. Paulo, 19 de Junho de 1951 (Assinado ilegivelmente)-Assistente- 'N A D A M A I S. Ficaram arquivados en cartorio uma cópia dos tistatutos e um exemplar do Dífrio Oficial do Estado que publicou o referido extrato. Foram aplicados e inutilizados os devidos selos de emolumentos. O referido é verdade e Dou fé. são Paulo,20 de Novembro de 1951.-0 Qul oficial cect. -






\section{1rogd}

Tese apresentada no II Congresso Paulista de Teatro Amador, pela ilustre bancada do Tea. tro Paulista do Estudante e que veio dar origem ao Festival de Teatro Nacional, que em bre. ve será realizado em São Paulo.

Verifica-se em nossa terra e muito particularmente em São Paulo, um verdadeiro surto de teatro. O interêsse pela arte cênica vem aumentando progressivamente, o cue é atestado pelo grande número de novos grupos de teatro amador e pelo aprimoramento artístico do repertório das Companhias profissionais.

Tal fato não se dá por acaso. Colhemos hoje os primeiros frutos do trabalho insano de alguns obstinados e até mesmo heróicos idealistas que visavam o incremento da arte cênica entre nós e, particularmente, o incremento do teatro amador.

Vencidos os primeiros obstáculos e colhidos os primeiros frutos, resta-nos perguntar: "De que forma é encarado o Teatro pelos que o praticam. em especial modo o Teatro Amador?" Acreditamos que a maioria dos artistas encara o Teatro na sua plenitude, surpreende a enorme importância cultural que possui, observa-lhe o poder de divulgação; na interligação entre artistas, autor e público divisa a influência direta do teatro sôbre o povo. Isto aliás, não é novidade.

Diziamos que o Teatro, particularmente o Teatro Amador, vem tendo novo impulso. Notamos a importância, digamos social, do Teatro. Vejamos agora a posição do Teatro Amador impulsionado e fortalecido diante de sua importância.

Ao falarmos de problemas relativos à cultura, não nos podemos esquecer de um elemento que geralmente esquece êsses problemas. Êsse elemento é o Govêrno. Uma simples vista d'olhos na verba destinada à educação, em relação com a verba destinada a outros setores, notadamente o militar, demonstra-nos o quanto é relegado a derradeiro plano o problema da cultura.

- Teatro Profissional sofre com a incúria dos responsáveis pelo Govêrno. Sem nenhum auxílio financeiro, é obrigado a lançar mão da elevação do preco das entradas o que motiva a restrição de público, constituido de uma minoria, ficando o povo impossibilitado de ver êsse Teatro. Noventa cruzeiros por uma poltrona só mesmo em dia de grande festa ou de loucura.

O Teatro Amador por sua vez, também luta com a incúria governamental. Assoberba-se de problemas. No entanto, o preço cobrado por ingresso por um grupo amador não atinge o montante do cobrado por uma Companhia Profissional. O número de grupos amadores supera em muito - número de Companhias Profissionais. E existe ainda o espírito que se esboça em meio aos construtores do Teatro Amador: o espírito de amor ao teatro, de devoção à cultura, de desdém ao sacrífício, de luta por rápido progresso e aprimoramento técnico e artístico. Cremos que, analisando tais fatôres, concluiremos que o raio de ação do Teatro Amador, tomando-se os grupos amadores em seu conjunto, supera o do Teatro Profissional. 0 público de espetáculos amadores é constituido, realmente, pelo povo, enquanto, como nós afirmamos, a assistência das Companhias Profissionais restringe-se a uma minoria de abastados.

Temos que notar, ainda, a facilidade que possui - Teatro Amador em penetrar nas fábricas, escolas e fazendas, proporcionando assim a operários, estudantes e camponezes o contato com o teatro, levando a mensagem dos autores realmente em meio ao povo.

Diante dessas premissas vemos quão é importante o Teatro Amador, particularmente no momento atual, e quanto é grande a responsabilidade dos que se dedicam a êsse Teatro. Se de um lado - Teatro, como tôdas manifestaçôes artísticas, pode aducar, divertir, incentivar, mal orientado poderá transviar, degenerar, entorpecer.

Embora o nível cultural de nosso povo seja, na verdade, baixo: embora a assistência dada a nosso povo seja ínfima; embora o sofrer de nosso povo seja imenso, nosso povo canta, nosso povo representa, escondido nas mais variadas regiö́es de nossa terra. Nosso povo acalenta lendas, nosso povo é poeta, nosso povo é artista. Com adorável ingenuidade, exprime tudo o que lhe vai pelo coração. $\mathrm{E}$ homens tivemos que nas letras e nas artes souberam transmitir o sentimento de nosso povo.

Embora muitos, levados por interêsses outros, teimem em negar uma tradicão cultural aos brasileiros, ela existe. Possuimos e podemos bradar: bem alto, uma herança cultural. Possuimos uma cultura nossa e necessitamos incrementá-la. O Teatro, o Teatro Amador não se pode furtar a essa missão. Deve partir dos responsáveis por êsse Teatro uma verdadeira campanha de incentivo, de incremento e defesa da nossa cultura.

Um povo culto é um povo independente. $\mathrm{E}$ não há beleza mais amada por nosso povo que a independência e liberdade.

Da divulgação de obras de conteúdo nacional, impregnadas de humanismo que faz vibrar os povos; do estudo e divulgação de nossas obras culturais, do aprimoramento do gôsto artístico, da representação de obras mestras de outros povos, deve viver o nosso teatro.

Os problemas da cultura não vivem independentemente de problemas políticos e econômicos. Um povo entorpecido é um povo que na passividade se entrega à rapina e à escravidảo. Um povo entorpecido é o que não ama, nāo quer, não luta. $\mathrm{E}$ a cultura destinada a entorpecer um povo é aquela que se desliga dêsse mesmo povo, que se desvencilha de seus sentimentos, paixões e aspirações, é a que foge dele, é a que se abstraindo do humano, deturpa e entorpece.

A missão do Teatro Amador é grande e honrosa. Os que se dedicam ao Teatro Amador estão aptos a cumprir tal missão.

O II Festival Paulista de Teatro Amador veio atestar os progressos que fizemos, tanto técnicos como artísticos.

Os amadores de teatro, unidos pelo amor ao teatro, saberão compreender a responsabilidade que os reveste. 


\section{TERMOS DE ACORDO ENTRE O TEATRO DE ARENA E O TEATRO PAULISTA DO ESTUDANTE}

1- OBJETIVO:

a) Formação de um numeroso elenco que atuará sob a denominação de ELENCO PERMANENTE DO TEATRO DE ARENA.

b) Formação de um movimento teatral de apoio às obras e autores nacionais, bem como de divulgação teórica e prática das coisas de teatro.

c) Ajuda ao já consagrado T.A. por parte do T.P.E. que o considera instituição de grande utilidade para nossa cultura e, ao mesmo tempo ajuda do T.A. ap T.P.E. através de aulas, formação de novos elementos etc.

d) Divulgação da arte cênica em fábricas, escolas e cidades do interior do Estado.

2- DA ORGANIZAÇÃO:

a) O elenco do T.P.E. a partir da data em que vigorar o presente acordo, será considerado elenco permanente do T.A., passando a atuar sob a denominação "Elenco Permanente do Teatro de Arena".

b) Constará no programa, ao lado de cada nome dos componentes do T.P.E. as iniciais "T.P.E.", bem como um histórico do mesmo e uma sintese do presente acordo.

c) Fica reservado ao T.P.E. o direito de utilizar seus elementos que não estejam comprometidos pela programação do elenco permanente, em realizações que decorrerão sob a responsabilidade do T.P.E.

d) Os elementos do T.P.E. somente poderão participar das viagens ao interior do Estado aos sábados e domingos, durante o período letivo. 
e) A Direção Artística deverá procurar poupar os elementos estudantes do T.P.E. durante os meses de exame (junho e dezembro).

f) Será dado ao T.P.E., como entidade, o encargo da organização de palestras, debates, mesas-redondas etc, que serão realizados no T.A. e constituirão o trabalho de difusão teórica.

g) Ambas as entidades não perderão sua autonomia, funcionando suas direções normalmente.

h) O elenco permanente será obrigado a dar espetáculos em fábricas, escolas, clubes etc. a preço de custo, ficando tais espetáculos limitados ao número de 05 por mês.

i) Os responsáveis diretos pelas duas entidades manterão contacto permanente, zelando pelo cumprimento do presente acordo.

j) Quinzenalmente realizar-se-á uma reunião dos responsáveis pelas entidades para discussão do trabalho efetuado e planos futuros.

k) As duas entidades manterão um sistema de trabalho baseado no apoio mútuo, comunicando uma a outra seus planos extraprogramação comum.

Parágrafo Único - No caso de incompatibilidade estatutária ou de princípios de uma das entidades em relação a pronunciamento que uma das partes contratantes se veja na obrigação de fazer pela imprensa, rádio ou qualquer outro meio de difusão; após entendimento mútuo, tal pronunciamento será feito ressalvando a responsabilidade da entidade discordante.

1) O presente acordo deixará de vigorar quando os responsáveis pelas 2 entidades deixarem de sê-lo.

m) A participação ao público do presente acordo deverá evidenciar a fusão das entidades como também a autonomia das mesmas.

n) O presente acordo será válido pelo prazo de um ano, em caráter experimental, podendo ser renovado mediante consentimento de ambas as entidades. 


\section{3- DAS FINANÇAS}

a) O T.P.E. receberá mensalmente do T.A. uma doação de Cr\$13.000,00 (treze mil cruzeiros).

b) O T.P.E. receberá $10 \%$ (dez por cento) sobre o montante das mensalidades pagas pelos sócios do T.A.

c) O T.P.E. receberá porcentagem sobre a venda de espetáculos por ele efetivado tanto na Capital como no interior.

d) Um espetáculo extra, será oferecido aos sócios do T.P.E. gratuitamente e aos estudantes em geral mediante o pagamento de Cr\$20,00 (vinte cruzeiros).

Parágrafo Único - o preço da entrada de estudantes a que se refere o artigo acima, poderá ser modificado mediante acordo entre as partes contratantes.

e) A tesouraria do T.A. será responsável pela produção em geral dos espetáculos.

f) A tesouraria do T.P.E. arcará com as despesas da parte de difusão.

4- DA DIREÇÃO ARTÍSTICA:

a) O Diretor Artístico do Teatro de Arena será o Diretor Artístico do Elenco Permanente T.P.E.-T.A., sendo outrossim orientador artístico do T.P.E.

b) O T.P.E. poderá não aceitar sua participação em peças de conteúdo político-partidário ou religioso.

c) A Direção Artística deverá cooperar ativamente com a parte de difusão ministrando aulas bem como facilitando o referido trabalho em todos os sentidos.

d) No plano artístico não haverá distinção entre elementos do T.P.E. e do T.A..

5 - DAS DISPOSIÇÕES GERAIS:

a) O presente acordo poderá ser modificado, ampliado etc. mediante acordo entre ambas as entidades, no decurso de sua validade. 
b) Os casos omissos no presente regimento serão resolvidos nas reuniōes quinzenais de que se trata o art. $\mathrm{j}$ do capitulo 2 .

SÃO DEVERES DO T.P.E.

1- Divulgar o nome do T.A. e T.P.E. fundidos.

2 - Fornecer elementos para as atividades do grupo.

3- Ter os 5 elementos de sua diretoria trabalhando unidos com os da direção do T.A..

4- Ampliar seu elenco.

5- Zelar pelo cumprimento dos compromissos assumidos junto a seus elementos.

6- Viajar para o interior quando solicitado, ressalvado-se o exposto no art. d, cap. 2 do acordo.

7- Ativizar à parte de divulgação teórica.

8- Esforçar-se para a venda de espetáculos na Capital e Interior do Estado.

9- Zelar pela disciplina do seus elementos.

SÃO DIREITOS DO T.P.E.

1-Ter suas iniciais ao lado do nome de cada um dos seus componentes no programa dos espetáculos, bem como um histórico do grupo.

2- Utilizar os seus elementos não comprometidos pela programação do elenco permanente em realizações particulares.

3- Fica reservado ao elemento do T.P.E. não aceitar sua participação em determinado periodo, devendo para tanto comunicar seu impedimento à Direção Artística com 30 dias de antecedência.

4- Viajar para o Interior apenas aos sábados e domingos.

5- Ter poupado durante o periodo de exames seus elementos estudantes. 